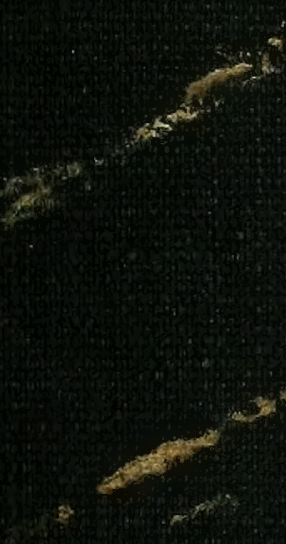




$$
\text { ช }
$$





\section{THE COMMERCIAL SPONGES AND THE SPONGE FISHERIES}

From BULIETIN OF THE BUREAU OF FISHERIES, Volame XXVII, IgO8

Proceedings of the Fourth International Fishery Congress : : Washington, 1008

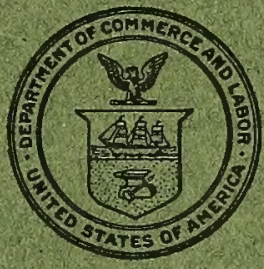

WASHINGTON : : : : : : GOVERNMENT PRINTING OFHTCE : : : : : : 1910 


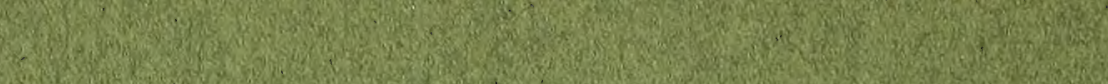

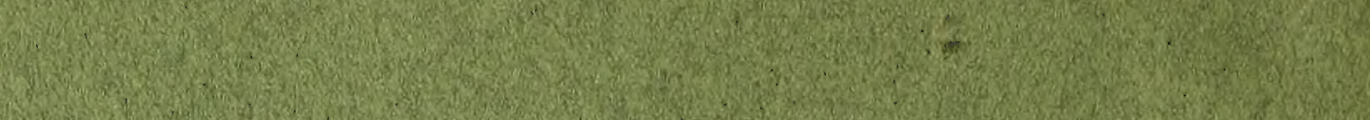

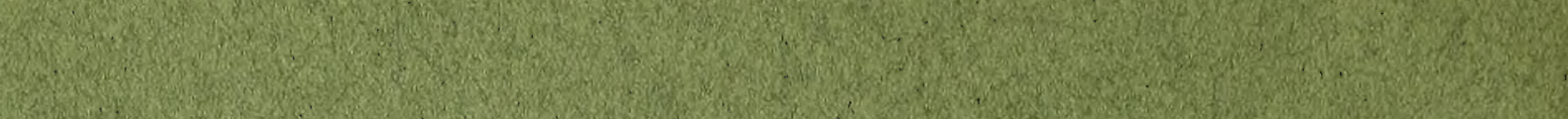

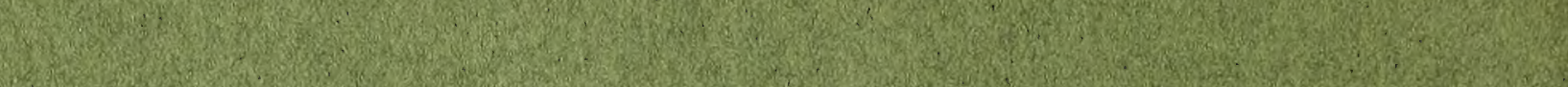

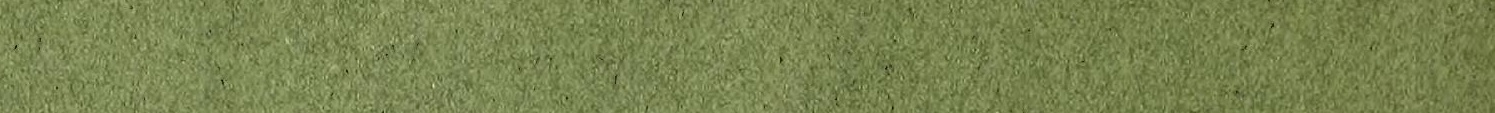
(1) (1) (1) (1) (1) (1)

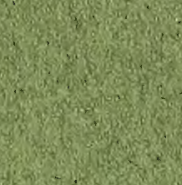
(1) (1) .

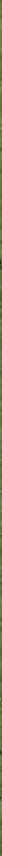
2.

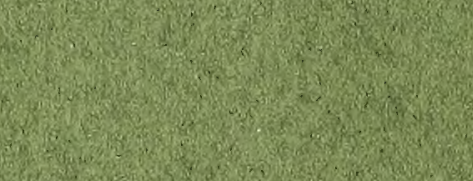
(2)

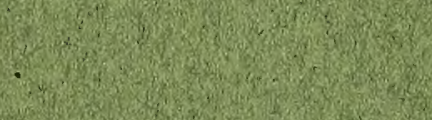
(2) (2)

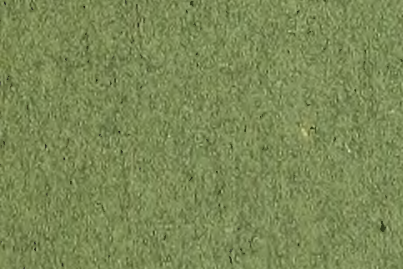

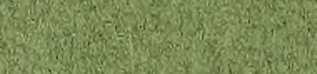
2. 1. W.

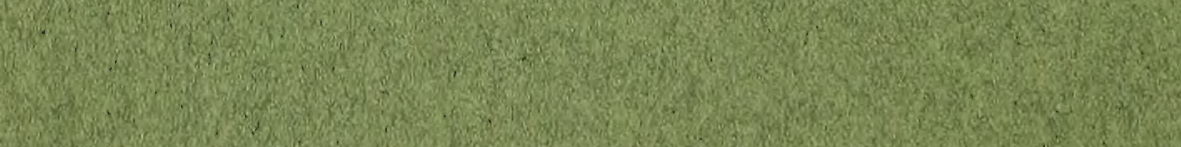

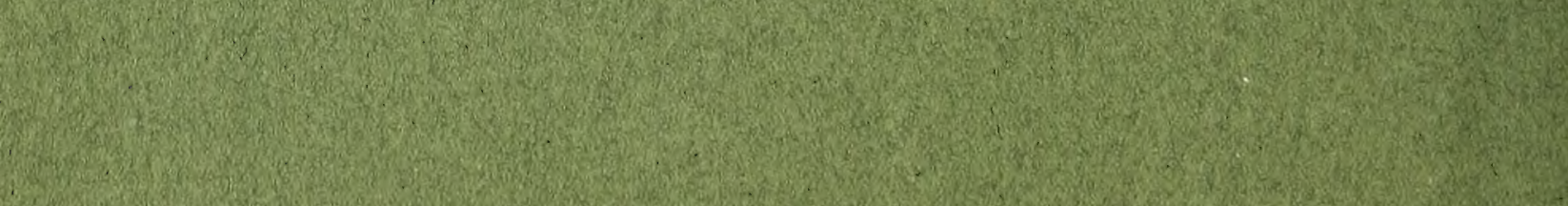

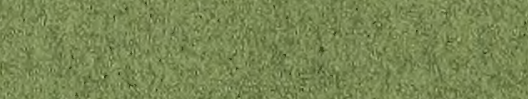

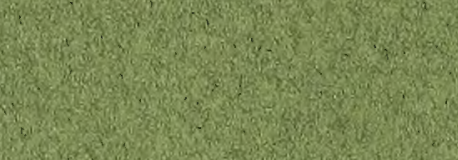
(1)

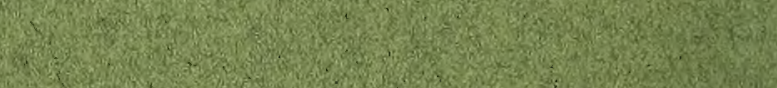
s. 


\section{THE COMMERCIAL SPONGES AND THE SPONGE FISHERIES * * * *}

From BULLETIN OF THE BUREAU OF FISHERIES, Volume XXVIII, I908

Proceedings of the Fourth International Fishery Congress : Washington, I008
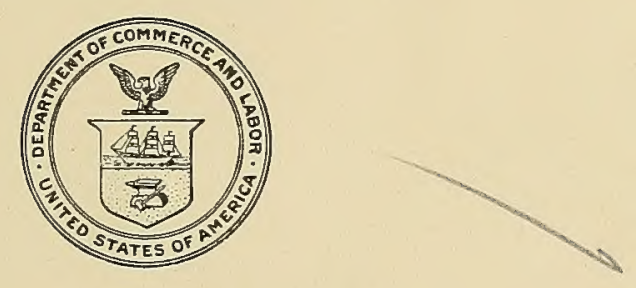

(1)

WASHINGTON : : : : : : GOVERNMENT PRINTING OFFICE $: \quad: \quad: \quad: \quad: \quad: 1910$ 


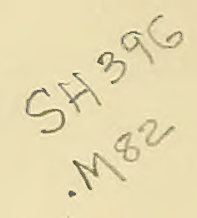

BUREAU OF FISHERIES DOCUMENT NO. 667

Issued March, 1910

\author{
AR 251910 \\ $9 . \mathrm{arb}$
}


THE COMMERCIAL SPONGES AND THE SPONGE FISHERIES

\author{
$\infty$ \\ By H. F. Moore
}

Scientific Assistant, United States Bureau of Fisheries

*

Paper presented before the Fourth International Fishery Congress held at Washington, U. S. A., September 22 to 26, 1908, and awarded the prize of one hundred dollars in gold offered by John $\mathrm{K}$. Cheyney for the best presentation treating of the methods of the sponge fisheries, the influence of such methods on the supply of sponges and the most effective means of conserving the sponge grounds 



\section{CONTENTS.}

$\infty$

Introduction . .

I. The living sponge............ 404

II. Requisites of a commercial sponge $\ldots \ldots \ldots$.

Color

Size and shape

Softness_._.

Fineness_...

Toughness and durability _.............

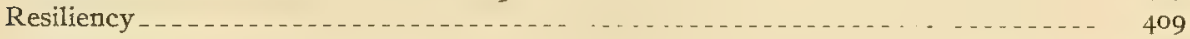

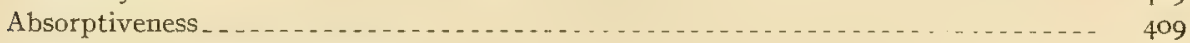

III. The commercial varieties of sponges $\ldots \ldots \ldots \ldots$

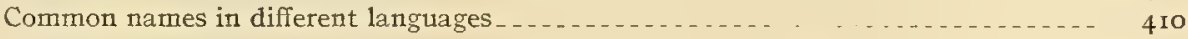

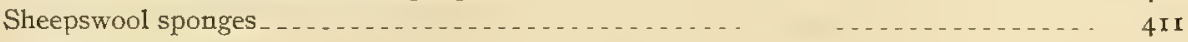

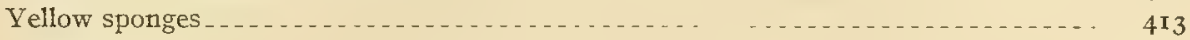

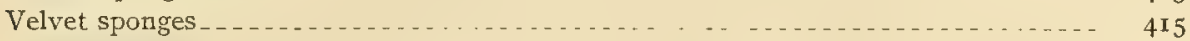

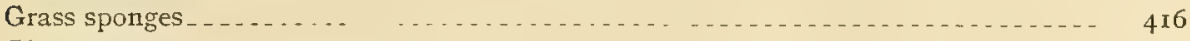

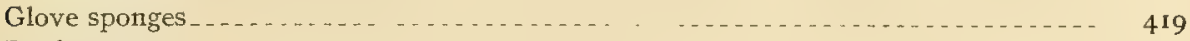

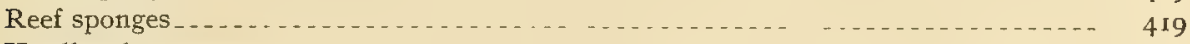

Hardhead sponges .........

Wire sponges _.......... _...

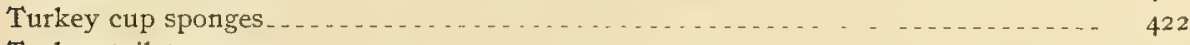

Turkey toilet sponges _........

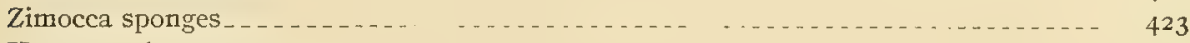

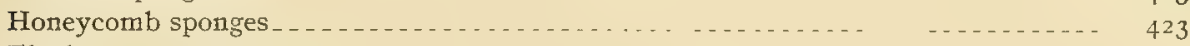

Elephant-ear sponges _...... . .

IV. The Florida sponge fisheries _.

The sponging grounds _...

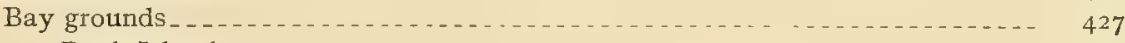

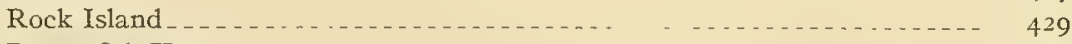

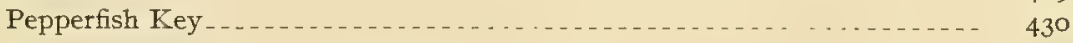

New ground

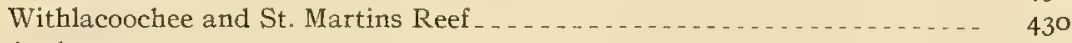

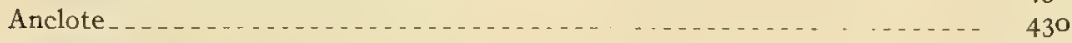

Highlands . . . . . . . .

Key grounds

New grounds.................

West of Key West_..... 433

Between Key West and Bahia Honda ........................ 433

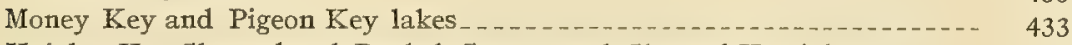

Knights Key Channel and Rachel, Grassy, and Channel Key lakes....... 433

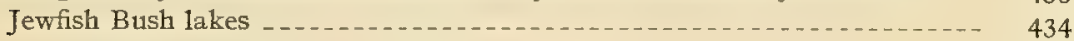

Lignum-Vitæ and Cotton Key lakes_... . . . . . . . . . . . . . . . . 434

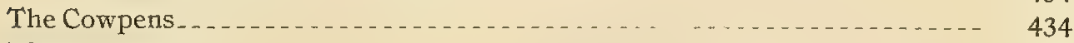

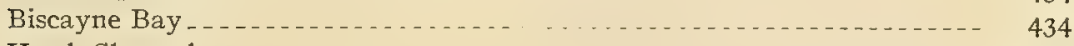

Hawk Channel ...

Hooking - .

Diving

B. B. F. I908-26 401 
IV. The Florida sponge fisheries-Continued.

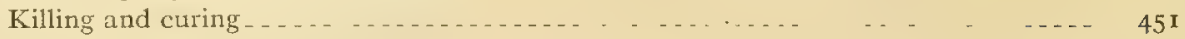

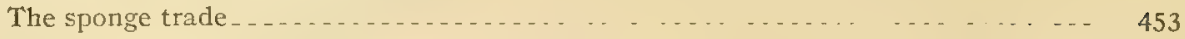

Sponge buying . . . . . . . . . . . . . . . . . . . 453

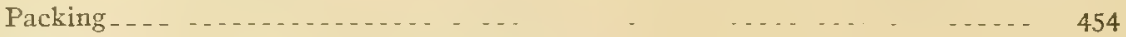

Bleaching _.......

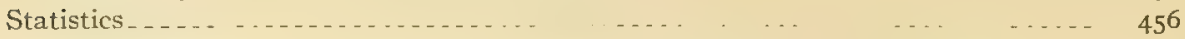

Foreign sponge tradẻ of the United States......... . . . .

V. Other western Atlantic sponge fisheries _. 470

Bahama Islands

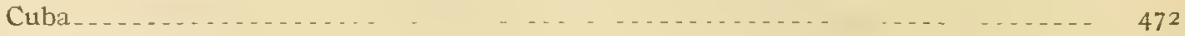

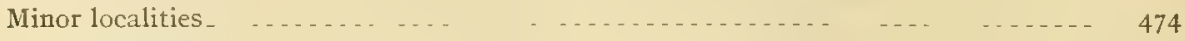

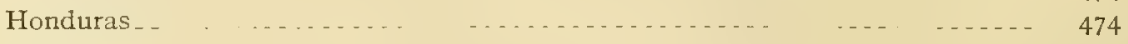

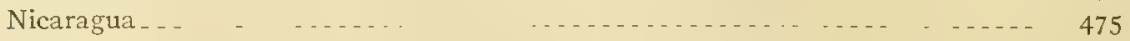

Mexico_... - ....... _ . . .

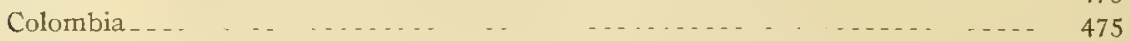

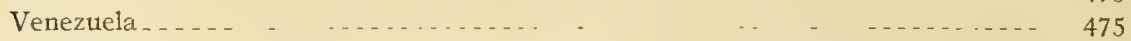

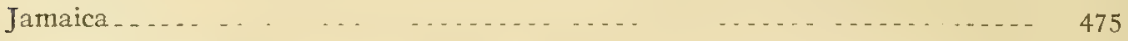

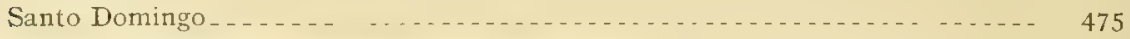

VI. Sponge fisheries of the Mediterranean and contiguous waters_._.

Spain and France

Adriatic Sea _._.

Figean Sea and Asia Minor _.

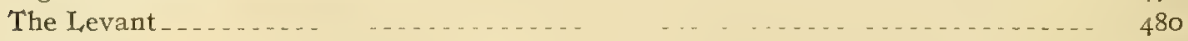

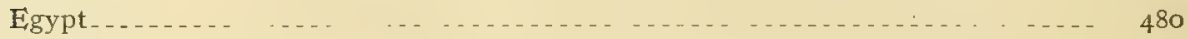

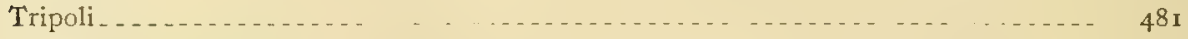

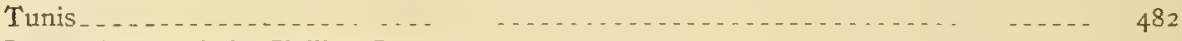

Lampedusa and the Sicilian Sea. _...

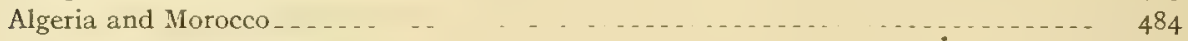

Methods of the fisheries _.

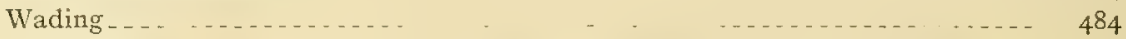

Nude diving . .

Harpooning . . . . . . . . .

Dredging or trawling

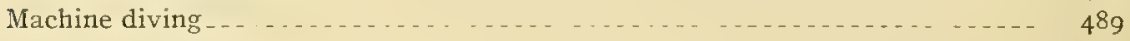

Cleaning and curing ............... . . . . . . .

VII. Various minor localities_... 491

Philippine Islands $\ldots \ldots \ldots \ldots \ldots$.

Australia and New Zealand _............ 492

Other Pacific islands _... . . . . . . . . . . . . . . . . . . $4 \ldots 3$

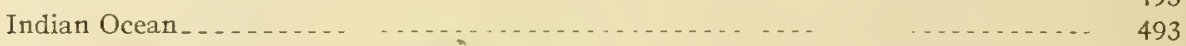

Mid-Atlantic Ocean_....... 493

VIII. Conditions and effects of the sponge fisheries.

Depletion of the beds_.

Hooking and harpooning . .

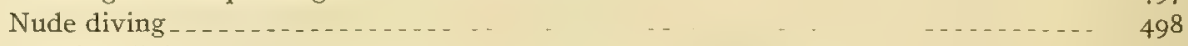

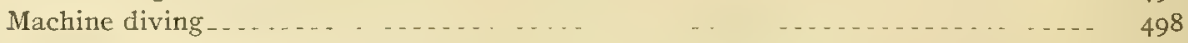

Dredging or trawling _...

IX. Regulation and protection of the sponge fisheries, with particular reference to Florida.... 503

Measures in force

Measures proposed

$\mathrm{X}$. Conclusions and recommendations as to the Florida sponge fishery _...... 509

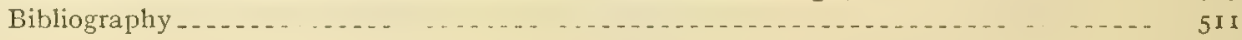




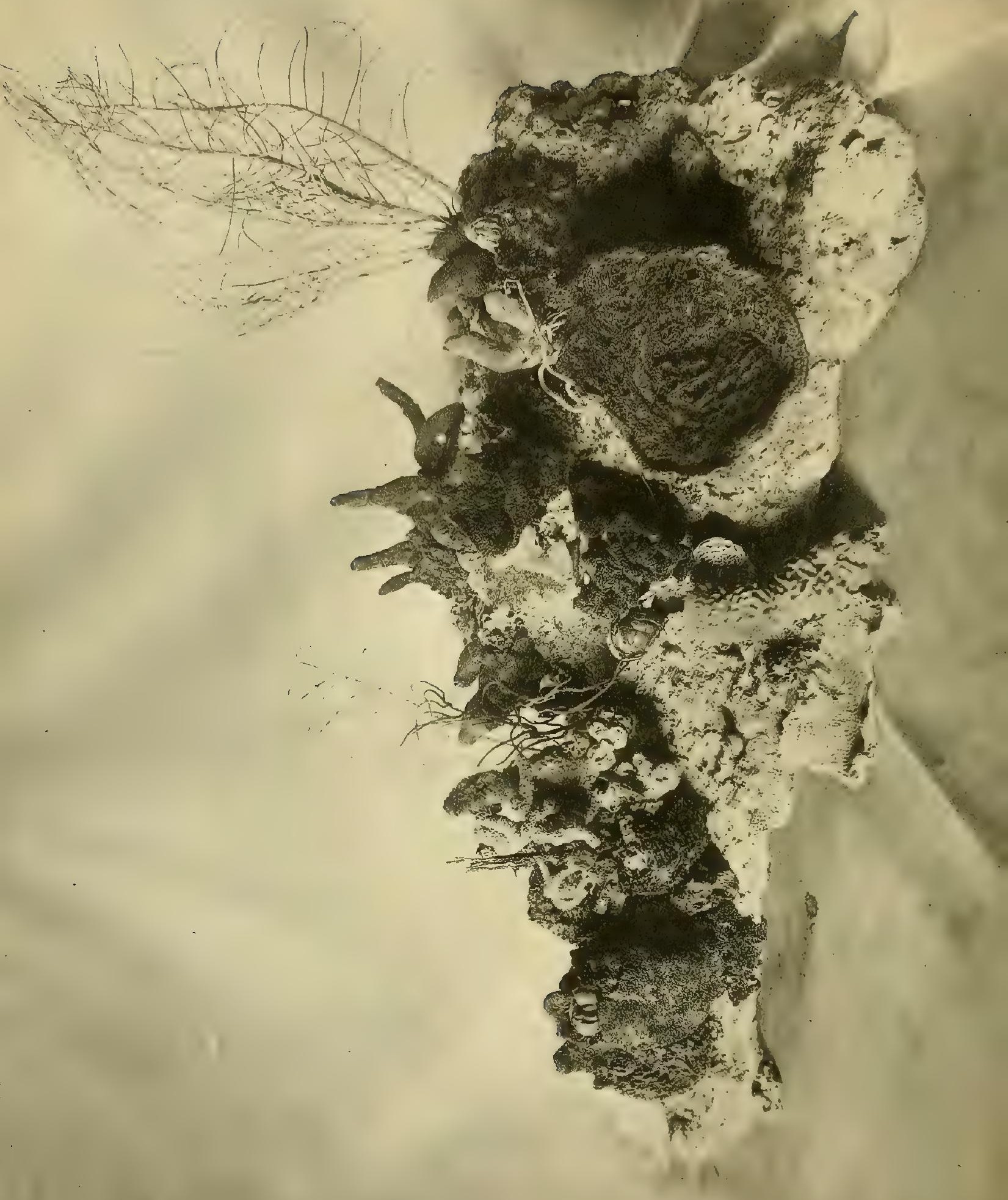




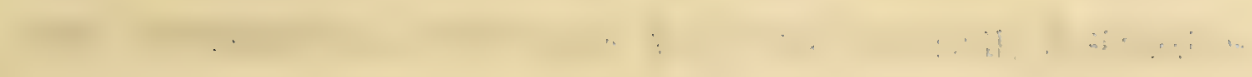

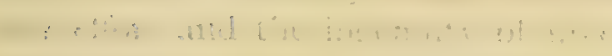

froduced and it is tormitre

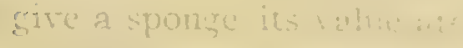

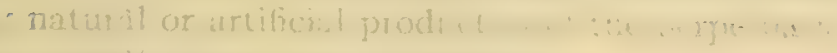

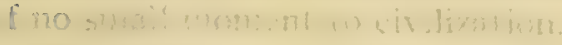

a...
ref $19120 \mathrm{~T}$
the tise thin HHVXX stsiq

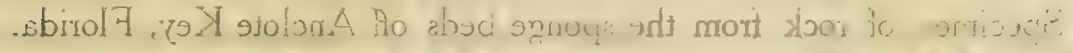

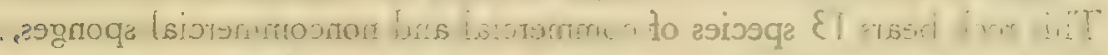

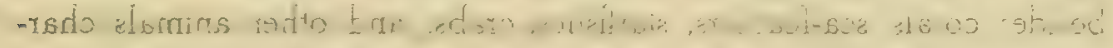

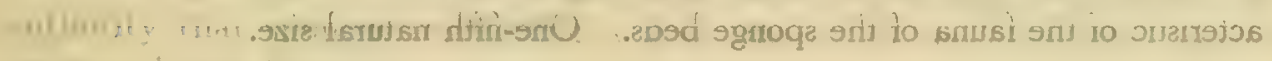

W. trath

$$
1
$$




\section{Plate XXVIII}

Specimen of rock from the sponge beds of Anclote Key, Florida. This rock bears 13 species of commercial and noncommercial sponges, besides corals, sea-feathers, starfishes, crabs, and other animals characteristic of the fauna of the sponge beds. One-fifth natural size. 


\title{
THE COMMERCIAL SPONGES AND THE SPONGE FISHERIES.
}

\author{
$\$$ \\ By H. F. MOORE, \\ Scientific Assistant, United States Bureau of Fisheries. \\ \%
}

INTRODUCTION.

Sponges are known to the general public almost solely from their use in the toilet, one of their minor applications. They are vastly more valuable in/the arts. In many trades they are practically indispensable, and despite long effort and the ingenuity of inventors no satisfactory substitute has ever been produced and it is doubtful whether one can be found. The properties that give a sponge its value are many, they are found in combination in no other natural or artificial product, and the perpetuation of the sponge supply is of no small moment to civilization.

The commercial sponges and their congeners are of wide distribution in the warmer waters, but the fisheries as at present developed are almost entirely restricted to the Mediterranean Sea, the Caribbean Sea, the Gulf of Mexico, and waters contiguous to these. Recently attempts have been made to establish a fishery in Australia, within the last year (roos) a few sponges have been shipped from the Philippines, and it is stated on rather vague authority that sponges resembling a poor quality of the Mediterranean toilet are now being fished on the coast of Madagascar. But the product of these regions is negligible in the markets of the world.

The Mediterranean fishery is of considerable antiquity, and it now produces over half in value of the world's supply, though it is inpossible to obtain accurate statistics for all countries on its border. The newer fisheries of the American coast produce by far the largest quantity, but a predominance of lower-priced kinds reduces the value to about three-fourths of that of the Mediterranean fisheries. The following table gives approximately the world's annual yield at the present time:

Mediterranean and contiguous waters (partly estimated)
Florida, I903-1908 (average)
Cuba, 1903-1906 (average)
Bahamas, 1900-1905 (average)
Other localities (estimated)

Total 
This paper, in conjunction with another on sponge culture, ${ }^{a}$ is designed to furnish a brief, but fairly comprehensive, review of present knowledge of commercial sponges, the geographical distribution of the fisheries, the methods employed, the effects of those methods upon the natural beds, and the measures which appear to be necessary for the protection and conservation of the supply.

Concerning the qualities and the characteristics that distinguish sponges of different grades and values, the consumer is probably less informed than in respect to any other natural product in general use, and he is frequently imposed upon. In many cases it is difficult for even an expert to identify the different local varieties, though there is much difference between them in the qualities that fix their value for practical use. The distinctions by which the various grades can be recognized are, moreover, such as to be difficult or impossible of expression in words. For these reasons the illustrations of this paper have been prepared, with especial care, to supplement the descriptions. The sponges pictured are typical specimens of the numerous local varieties and without exception represent sponges now on the market.

As the purposes of the paper are mainly practical and economic, the discussion of the scientific status of the various kinds of commercial sponges, their general biology and morphology, has been reduced to the minimum necessary for a proper understanding of their nature and the problems which must be solved before the regulation of the beds can be placed on a rational and effective basis. The question of the scientific classification of the commercial varieties will be taken. up some time in the future, when the accumulation of material and certain experimental data may offer some guarantee of better results than have been attained previously. The subject is one of extreme difficulty, and it is not believed that it can be successfully attacked without the assistance furnished by a well-equipped laboratory in the vicinity of the sponge grounds.

\section{THE LIVING SPONGE.}

To most persons familiar only with the sponges of the shops, the animal as it comes from the sea would be entirely unrecognizable. (Plate xxvirr.) It is a solid looking, rather slimy feeling, fleshy body, varying in color from lightgreyish yellow through a considerable range of browns to black, and in form either cup-shaped, spheroidal, or cake-shaped, according to the species, its age, or the environment in which it grew. In general, in appearance and consistency and the manner in which it cuts with a knife, a living sheepswool sponge is not unlike a piece of beef liver, perforated with holes and canals.

a Moore, H. F.: A practical method of sponge culture, Proceedings International Fishery Congress, in Bulletin U. S. Bureau of Fisheries, vol. XxvIII, 1908, p. $545-585$. 
The sponge of the markets is merely the skeleton, the supporting framework, which gives strength and form to the soft gelatinous tissues of the living animal. It is composed of a substance similar in general chemical and physical properties to silk, horn, and chitin, the basic material which forms the shells of insects and crabs. This material is distributed in a fibrous network, usually in accordance with a definite general pattern in each species; the diameters of the fibers, the sizes of the meshes, and the relations existing between the several parts lying within more or less well-fixed limits. In addition, the main fibers always contain more or less foreign matter, sand grains, spicules, etc., embedded in their substance in the form of a core.

A casual examination of the living sponge will show it to be covered by a well-defined skin raised at more or less regular intervals into blunt little cones over the ends of the skeletal fibers, by which it is supported. Distributed over the surface, sometimes rather generally, sometimes locally, are sieve-like membranes, whose small pores lead into cavities lying just below the skin. From these cavities canals lead into the substance of the sponge, opening by numerous minute pores into as many small pear-shaped chambers, which from their opposite ends discharge through larger openings. If the canals leading from these could be followed, it would be found that, uniting with their fellows, they gradually increase in diameter until they open upon the surface of the sponge in one of the large conspicuous pores known as "oscula," or, as the spongers call them, "eyes." The oscula are sometimes more or less generally distributed, sometimes localized, according to the species, and each is surrounded by a smooth membrane capable of expanding or contracting in such manner as to vary the size of the opening.

This canal system is one of the most important organs, as well as the most characteristic feature of the sponge. It is the sole means of feeding and practically the sole means of respiration. Its method of functioning is as follows: The pear-shaped chambers described above are lined with cells of a peculiar character, collar cells, as they are called, each provided with a little lash or cilium projecting into the chamber and beating rhythmically in such manner as to set up a current in one direction. The mechanical effort of each is feeble, but the joint action of the untold numbers of such cells in a sponge sucks water through the small orifices in the surface, first described, into the ciliated chambers and in turn forces it into the successively larger canals until it finds vent through the oscula. The water, with its contained food and oxygen, therefore enters the sponge through the small superficial pores and leaves it by the large ones. Excluding from consideration the foreign bodies, shells, coral, etc., which the sponge often overgrows and surrounds, the whole interior, save the skeleton and spaces of the canal system, is occupied by tissues which are neither of many 
varieties nor strongly differentiated. There are certain cells called "spongoblasts" which secrete the material of which the skeleton is composed. Collar cells and other epithelial elements line the ciliated chambers and the several canals with which they are in communication. The outer surface and the subsuperficial or subdermal surfaces are covered with a single layer of flat cells.

The main portion of the fleshy part of sponges is made up of what is known as ground substance, a jelly-like material, similar to that found in the umbrella of jelly fishes, without cellular structure, but containing connective tissue cells. Muscle cells are found in the skin, the canal walls, and the membranes around the peripheral pores, and nervous and sensory cells occur in association with them, an explanation of the limited sensitiveness and contractility which are noticed in handling live sponges.

Concerning the life histories of commercial sponges we know but little. In some species, at least, the sexes are separate, the females greatly preponderating, and the young are produced mainly if not solely from eggs. The young are, for a time, minute free-swimming organisms which may be carried considerable distances by the currents, and they are still very minute when they at last settle down for permanent attachment. At this stage, like oyster fry, they are liable to be covered and suffocated by comparatively thin deposits of sediment, and the object to which they can successfully attach must be hard and clean. It follows from this and from the fact that much of the sea bottom is more or less covered with soft deposits, however thin, that a vast majority of the young sponges fall on unsuitable bottom and are lost. This accounts in many cases for their irregular and sparse distribution on many rocky bottoms which superficial examination would indicate as favorable. The natural bars are undoubtedly capable of supporting a much heavier growth than they usually bear, and if partially grown sponges could be placed on them, as is proposed in the system of sponge culture elsewhere described, their productiveness could be enormously increased, as these deposits of sediment, fatal to the spat, would prove innocuous to larger individuals.

The rate of growth of sponges inl ler undisturbed natural conditions is not definitely known, but the experiments recounted in another connection " indicate that it is slower than is generally supposed by the spongers. There is very good reason to believe that the average antiual increase in diameter of sheepswool sponges in Florida waters is not greatly in excess of 1 to $I I / 4$ inches. The rate varies somewhat in different localities and under different conditions. The average 6-inch sponge is probably not far short of four years old, though possibly the early growth may be more rapid than the experiments indicated for later stages. 
Commercial sponges are very susceptible to the influences of environment, and when transplanted from one place to another speedily change in character. If grown in the midst of vegetation they become coarse and open in texture, of irregular shape, with long superficial processes and protruding oscular tubes. If raised high above the bottom the texture becomes more dense than that of neighboring bottom-grown specimens. Individuals suspended artificially on wires or growing naturally on gorgonians (sea feathers) tend to become spherical, and those torn loose to roll freely over the bottom assume the same shape, but develop harsh, very tough surfaces.

The commercial sponges of Florida, especially the sheepswool, yellow, and velvet sponges, can not live in water which falls for any considerable period much below oceanic salinity. Observations made in connection with sponge culture and on the natural beds indicate that the allowable minimum of salinity is reached when the water falls to a specific gravity of about I.org or I.02O. Exposure to the air is tolerated for considerable periods, especially during cool weather, and sponges grow naturally in situations where they are occasionally bared at low tide. From this extremely shallow water, the distribution of commercial sponges in Florida extends certainly to depths of I I feet and probably to much deeper water, as in the Mediterranean, where they range to a depth of 500 to 600 feet. Of the food of sponges practically nothing is known. That it is taken in through the canal system and that it must be in a finely divided state is practically certain, but of what it consists and by what tissues it is absorbed is unknown. The so-called "roots" of sponges perform no other purpose than that of anchorage and are not special organs of nutrition like the roots of plants.

There appear to be few, if any, important natural enemies of commercial sponges, though perhaps they are subject to the attacks of microscopic organisms, producing certain epidemics which are ordinarily attributed to other causes. Crabs are ofter found in cavities burrowed in their substance, but despite popular belief to the contrary, I do not think that the chambers are actually excavated by the crabs. They probably find them ready-made and when they crawl in the pressure of their shells prevents filling up, or possibly expands the cavity.

\section{REQUISITES OF A COMMERCIAL SPONGE.}

The qualities of the skeleton affecting the commercial value of sponges are color, size and shape, softness, fineness, durability, resiliency, and absorptiveness.

Color. - The color is the consideration of least intrinsic importance, though for purely esthetic reasons it exerts a considerable influence on the price. The most desired color varies somewhat with different classes of sponges, but in general the lighter tones àre preferred. For bath purposes a pale yellow appears to be most in demand, and this requirement is catered to by various processes 
of artificial bleaching. Sponges of the same species will frequently differ in color in different localities. The sheepswool of the Florida Keys, for instance, has a deep reddish brown "root" and interior, while this is lacking in Rock Island specimens, and the latter are also more grayish externally. As these color characteristics are correlated with differences in other qualities, especially durability, they are of value in distinguishing the grades. In general the sponges of commerce, i. e., the skeletons, are yellow, light brown, or brownish gray.

Size and shape.-The most desirable size and to some extent the shape depend upon the purpose to which the sponges are to be put. For surgical purposes small ones are required, for toilet use a medium size, while for cleaning vehicles and cars a large sponge holding a considerable quantity of water is necessary. Sponges up to about 8 inches in diameter are commonly used entire and called "forms," but above that size they are usually cut into pieces and known commercially as "cuts." Most or all American sponges of a less diameter than $4 \frac{\mathrm{I} / 2}{2}$ to 5 inches are of comparatively little use and value, but the Mediterranean grades find a market in even the smallest sizes. Some species possessing all the other requisites are debarred from the markets solely by their shape.

Whatever the form of a sponge, to be of commercial value it must be regular, more or less massive, and free from long processes and digitations. Certain of the inferior Cuban sheepswool sponges are about the only exception to this rule, and in the case of these the long, teat-like projections which carry the oscula at their summits are usually cut off more or less close to the massive base from which they rise. Under normal conditions all commercial sponges are either spheroidal, cake shaped, conical, or cupped. The gradations between these shapes are infinite and each species presents great variety, due to age, environment, and perhaps individual tendency. The shapes assumed by the various species will be considered in the descriptions of the several commercial varieties.

For general purposes the most desirable forms are the spheroidal and cake shaped. In applying the glaze to pottery, however, and in other similar wcrk, a smooth, flat surface is desired, and this is generally obtained either by cutting up the more massive forms or by taking pieces from a smooth-surfaced cupshaped sponge like the Mediterranean elephant's ear. The American roughsurfaced conical and cup-shaped sponges, like the Anclote grass, are usually cut, invariably so when they are of large size.

Softness.-The more desirable grades of sponges, other things being equal, are those which are softest, the cheaper, inferior grades being generally, though not always, more or less harsh. This quality depends upon the thickness and arrangement of the fibers, the amount of foreign matter included in them, and 
the openness of the canal system. Sponges with comparatively slender fibers, with the microscopic meshes rather open, with a small amount of foreign matter included in the spongin, and with an open canal system, are the softest. Those in which the fibers are heavily laden with sand are invariably harsh.

Fineness.-Fineness depends upon the macroscopic rather than on the microscopic arrangement of the skeleton, though the slenderness of the fibers is a factor. The Matecumbe sheepswool is one of the softest of sponges, but its open structure makes it appear coarse when compared with Mediterranean kinds. Fineness in the same species varies more or less with the environment under which the individual is produced.

Toughness and durability.-These qualities depend upon both the microscopic and the macroscopic characters of the sponge skeleton, and also apparently to some extent upon its chemical properties. These factors vary with the sort or species and in the same sort are subject to environmental differences. In any given species the looser the general structure and the larger and more numerous its canals and subdermal spaces, the more easily it is torn and the sooner it breaks down in use. The loose, open-textured sheepswool sponge of Biscayne Bay is much more quickly destroyed in a given service than is the denser Rock Island variety. That chemical factors also enter into the matter is apparently indicated by the greater tenderness of the red-rooted Key sheepswool as compared with equally open selected specimens from the Bay grounds not exhibiting this peculiar color.

Resiliency.-Upon this quality depends very largely the value of a sponge for economic purposes. Sponges are generally more elastic when dry and more compressible when wet, and if under the latter condition they return promptly to their original shape when the compression is removed they are more useful than if sluggish or "soggy" in their reaction. Resiliency depends upon the size of the fibers and the arrangement of the microscopic mesh work, and also upon the thoroughness and manner of cleaning. Specimens poorly cleaned and containing much "gurry" are sluggish in returning to shape after compression.

Absorptiveness. - This quality depends upon a combination of softness, fineness, and resiliency, and is the fundamental property upon which the usefulness of a sponge depends. A sponge that takes up little water or that absorbs it slowly or that drains quickly after it is removed from water is inferior for all purposes to one having the converse properties.

Water is absorbed by the capillarity of the mesh work, and the finer and closer this is the more water taken up and retained. The fibers themselves absorb a small amount of moisture, but this is not available for mechanical purposes, as it is released by evaporation only. Resiliency assists in absorption by promptly opening the meshes after compression, so that they act mechanically like so many minute pumps. The most copiously and quickly absorbent 
sponges have fine meshes, slender fibers, and generally close texture. Large canals and cavities decrease the amount of water which can be absorbed in proportion to the size of the sponge, though they do not necessarily affect the rapidity with which it is imbibed.

\section{THE COMMERCIAL VARIETIES OF SPONGES.}

Both the scientific and commercial classifications of economic sponges are much confused and unsatisfactory and the two are mutually contradictory. Sponges considered by zoologists as of the same species or variety are separated into different commercial grades or species often differing widely in value, and, conversely, the trade often recognizes under the same name species that are undoubtedly zoologically distinct. These animals are so extremely plastic and susceptible to the influences of local environment, changing form, appearance, and character so completely under changing conditions, that it appears hopeless to expect a satisfactory scientific arrangement until present methods of research and nomenclature are completely departed from. In the present paper, designed as it is for economic purposes, the commercial classification is followed, the probable scientific names of the sponges described being indicated but incidentally.

In the following list are given the names commonly used in several languages, but the commercial classification is much more complex than is here indicated. All of the principal kinds are further subdivided in the markets according to geographical origin, quality, and even the methods by which they are taken. Among American sponges, in addition to the various geographical and local designations we have "forms," "cuts," and "seconds," while in the Mediterranean there are "fines," "commons," "seconds" (écarts), plongées, harpoonées, etc.

Common Names of Commercial, Sponges in Different Languages.

\begin{tabular}{|c|c|c|c|}
\hline & & & =.......... \\
\hline Engglish. & Firench. & Cuban. & German. \\
\hline $\begin{array}{l}\text { Sheepswool; wool } \\
\text { Yellow } \\
\text { Velvet; boat } \\
\text { Grass } \\
\text { Silk grass } \\
\text { Glove } \\
\text { Reef; "West India surgeon's" } \\
\text { Hardhead; American zimocca } \\
\text { Turkey cup; 'Turkey solid } \\
\text { Toilet. } \\
\text { Zimocca. }\end{array}$ & $\begin{array}{l}\text { Indienne. } \\
\text { Boulet } \\
\text { Havanine. } \\
\text { Afrique } \\
\text { Tine Antille. } \\
\text { Coupe turque; fine douce } \\
\text { de Syrie; dè Archipel. } \\
\text { Fine douce de Adriatic. } \\
\text { Chimousse; fine dure. de } \\
\text { Syrie; fine Grecque. } \\
\text { Fine de Syrie; fine } \\
\text { blonde; commun de } \\
\text { l'Archipel, etc. } \\
\text { Oreille d'elephant. . . }\end{array}$ & $\begin{array}{l}\text { Hembra. } \\
\text { Macho fino. } \\
\text { Farao; aforrada. } \\
\text { Macho cueva. } \\
\text { Macho peludo. } \\
\text { Macho d ul ce ; macho } \\
\text { guante. } \\
\text { Macho dulce. } \\
\text { Machito fino. }\end{array}$ & $\begin{array}{l}\text { Feiner } \mathrm{L} \text { e v a } \mathrm{t} \text { i ner- } \\
\text { schwamm. } \\
\text { Levantinerschwamm. } \\
\text { Zimokkaschwamm. } \\
\text { Badeschwamm. } \\
\text { Ohrenschwamm: Mund- } \\
\text { schwamm; Levantiner- } \\
\text { lappen. }\end{array}$ \\
\hline
\end{tabular}


Common names of commercial sponges in different languages-Continued.

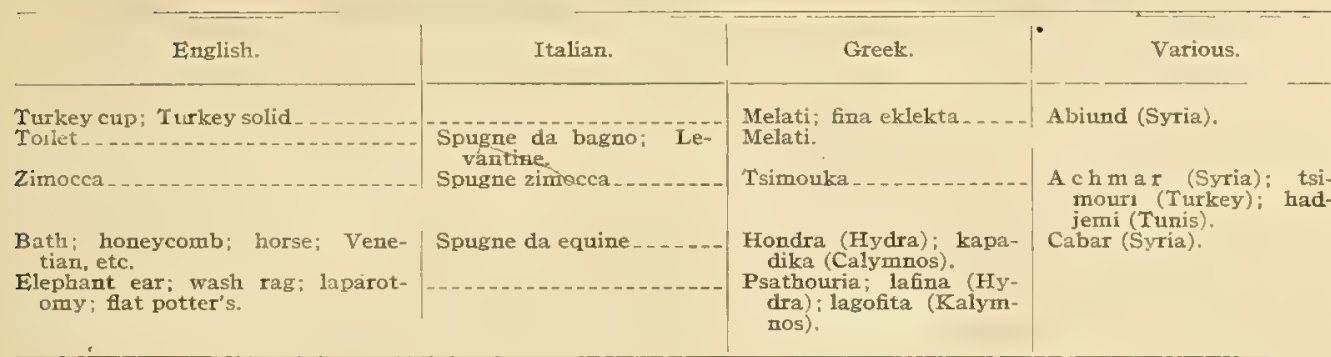

SHEEPSWOOL OR WOOL SPONGES.

Hippospongia canaliculata gossypina.

The sheepswool sponges, which are found in the Gulf of Mexico, the Caribbean Sea, and the adjacent parts of the Atlantic Ocean, all appear to belong to this variety, with the possible exception of certain specimens from Cuba, concerning which I am uncertain. They exhibit wide local variation, are very sensitive to environment, and when transplanted from one locality to another undergo marked change in character. The whole surface of the skeleton is tufted with fascicles of fibers, which are longer and more fimbriated in the shoalwater specimens. The oscula are confined to the upper surface, are large and comparatively few in number. They are usually surrounded with a circle of tufts and are often slightly, sometimes enormously, elevated on cones or tubes. The color of the living sponge is black, becoming brownish at the base. These sponges grow to a large size, I 8 inches or more in diameter, are soft, absorbent, very durable, and of good shape. They are unequaled for general bath purposes and for use in the arts. They are employed generally for cleaning carriages, cars, and other highly polished surfaces where size, softness, durability, and great capacity for holding water are required. The larger perfect forms are used as gun swabs in the army and navy, or are divided and sold as "cuts". for use by tile and brick layers, painters, potters, and other artisans. The market varieties are as follows:

Florida Rock Island (p1. xxx and XxxI).--These, the best and highest-priced sponges of North America, are found in the Gulf of Mexico, on the west coast of Florida between Johns Pass and St. Marks. They are generally rather flat and with a broad base, closely knit, soft and strong. The surface color is grayish brown and the root and interior are little tinged with red. Those from deeper water are superior to shallow-water specimens in texture, density, and durability.

Florida Key wool (pl. xxxII and xxxII).-This variety comes from the Key grounds elsewhere described, and is next in value to the Rock Island, which it surpasses in softness, especially if from near Matecumbe Keys, but does not equal in 
strength, durability, or capacity for holding water. The surface color is paler, and the interior and often the insides of the oscula and the surface channels are colored a rather bright red. The surface is generally well felted, but the interior is more open and the fibers weaker. It tends to grow proportionally higher than the Rock Island sponges, especially when young, and the base is narrower, an inverted pineapple shape being common.

Bahama wool (pl. XxxIV and Xxxv).--This is generally inferior to either the Rock Island or the Key wool, being coarser and more open and less durable and absorbent. The softest and best specimens come from the vicinity of Abaco. The shape is generally rather flat and the upper surface much tufted. Those from the vicinity of Andros Island are generally rounder than from other parts of the archipelago and the lamellæ tend to become thicker and less tufted on their free edges, sometimes remotely resembling the velvet sponge.

The Bahama wool sponges are pale yellow superficially and those from some localities have pale vermilion roots, while from other places they are practically untinged with that color.

Cuba wool (pl. xxxvi). -The ordinary Cuba sheepswool sponge has the same general characteristics as the Bahama variety, though inferior to Abaco specimens. Another form which is not uncommon, and which rather insufficient material indicates may be zoologically distinct from the other sheepswool sponges, has a rather flat incrusting base from which arise as many as thirty oscular tubes, sometimes reaching a length of 8 inches and 2 inches in diameter. These tubes swell somewhat toward their middles and tend to anastomose. Certain specimens indicate that this anastomosis may become so complete as to form fluted columnar sponges, twice as high as thick, with long stout oscular tubes on the upper surface. Lendenfeld does not recognize this as a distinct zoological variety.

Mexican wool. - This is the poorest of the sheepswool sponges, being coarse, loose of texture, much more tender than those that have been mentioned, and lacking in resiliency. Its surface color is dark-brownish gray and the root and interior are dull rusty red. In shape it is rather high, growing from a narrow base, and the oscular pores on the upper surface are large, open, and ragged. These sponges grow in the shallow waters, but it is stated that a type much superior is found in deeper water on certain parts of the coast, especially about the island of Cozumel.

Honduras wool.-On the coast of British Honduras is found a wool sponge which resembles the Mexican but is of slightly better quality. It has in most cases the same dull red or brown root and interior and the ragged oscular openings on the top. It has a lighter superficial color than Mexican specimens and appears to be rather stronger and more resilient. The sponges are usually irregular in shape, but this quality will probably be found improved in deeper water, those now taken being from the shallows. 
Other localities.-Sheepswool sponges are taken to a limited extent commercially, or are known zoologically, in Honduras, at the island of Gonaves, Haiti, and at other places in the Caribbean. In the Philippine Journal of Science Seal describes a wool sponge from the Philippine Islands. The specimen he exhibited to me had the appearance of a Bahama sheepswool, and had been used for bath purposes. It is not unlikely that it was imported and not indigenous.

\section{YELLOW SPONGES.}

Under this name are known sponges of several zoological species and varieties, some of which receive also other commercial names, according to quality, size, and locality. Though difiering much in details and special qualities, the yellow sponges have these characters in common: They are highly elastic and resilient, more so than any other American sponges with the possible exception of the Anclote grass, but they are harder than the wool sponges, less absorbent, and drain more freely. They are regular in shape, attractive in appearance, and grow to a diameter of about 18 inches, though this size is not common. The color is a rich yellow or yellowish brown, in some localities tinged with rust red or chestnut. The surface is never furnished with the long fibrous filaments characteristic of the sheepswool, but is covered with a nap of short hairs of uniform length and lying in a uniform plane. Though less durable than either the sheepswool or the velvet sponges, the yellow sponges are excellent for many purposes in the arts, and when bleached make attractive and soft, cheap bath sponges.

In the living condition they have smoother surfaces than the sheepswool, and are very dark brown on top, becoming yellower on the sides. The pseudoscula, vents, or "eyes" are in some varieties situated on the summits of low, rounded cones and in others lie in the general level of the upper surface. They are never surrounded by circles of fimbriated tufts as in the sheepswool, or compounded as in the velvet sponge. They are generally large and conspicuous. The commercial varieties of yellow sponges are as follows:

Florida Key yellow (pl. XXXVII, XXXVIII, and XXXIX). - This is the finest grade of yellow sponge, being softer and more durable than the Anclote yellow or the foreign varieties. The best come from the vicinity of Matecumbe Keys, where the common species is Hippospongia equina elastica Lendenfeld. This species is massive, cake-shaped, or, commonly, in the form of truncated cones attached by a narrow base. The lamellæ form a network lying in a uniform surface, are usually more or less thickened at their free edges and inclose numerous more or less uniform polygonal, circular, or meandering orifices. The surface of the skeleton is more continuous than in most of the other American sponges. The vents or "eyes" usually lie in the general level of the upper surface, but are sometimes, especially 
in the larger specimens, raised on soft rounded cones or craters, the rims of which are generally interrupted in one or two places.

Another variety of Key yellow sponge is Euspongia irregularis periusa, the common form of the Anclote region and Cuba, but this is inferior and less numerous.

Anclote yellow (pl. $\mathrm{XL}$ and $\mathrm{XLI}$ ).-These consist almost wholly of the zoological variety last mentioned. They are more massive than the common Key yellow and are almost invariably attached by a broad base, from which the sides and tops rise in a more or less regularly convex surface, bearing low, broad cones or lumps on the summits of which the oscula open. The latter occur more or less over both sides and top, and are not confined to the upper surface as in the preceding species. The surface of the skeleton is more uneven and lumpy than in Hippospongia equina elastica and the superficial villi of fibers are longer and more tufted and frequently connected with one another by an irregular loose network of fine fibers.

These sponges are harsher and less compressible than the Key yellow and less desirable for commercial purposes.

Bahama yellow ( $\mathrm{pl}$. XLII and $\mathrm{XLIII).-There} \mathrm{are} \mathrm{two} \mathrm{common} \mathrm{species} \mathrm{of}$ Bahama yellow sponges. One is Euspongia irregularis pertusa, the common Anclote form, from which it differs mainly in the more numerous oscula and the brighter yellow color of the skeleton.

The other is Hyatt's Spongia agaricina subsp. dura, which Lendenfeld apparently erroneously includes with his Hippospongia equina meandriformis. This sponge is more open in texture and less strong than the foregoing, but softer and more quickly absorbent. It is spheroidal in shape, though often one-sided on account of lateral attachment to the rocks, and the free ends of the lamellæ lie in a common surface as in the velvet sponge, but the exterior faces, instead of being felted and compact, are covered with a nap of loose-ended fibers, giving the whole surface a villous appearance and a rougher feel. The lamellæ consist of radially arranged/club-shaped bundles connected by tangential buttresses or lugs, making a weak structure easily torn into radial shreds. The color is light brown. The oscula are single, not compound as in the velvet sponges, and are scattered over the upper surface and occasionally on the sides. Hyatt says that this is the "hardhead," but so far as I have observed the spongers now class it as "yellow." It appears to be particularly common near Andros Island.

The common yellow sponge of the Florida Keys is also found in the Bahamas, but does not appear to be generally included among shipments of yellow sponges.

Cuba yellow (pl.XLIV).-The common Cuba yellow sponge is the same species as the Anclote yellow, Euspongia irregularis pertusa, from which it differs mainly 
in its brighter color and more cavernous structure, the oscula being more numerous and the blunt cones in which they are situated being separated in the skeleton by clefts entering rather deeply into the body of the sponge.

A variety similar to the Key sponge is found on the north coast of Cuba.

Honduras yellow.-This commercial variety, which comes from British Honduras, is the same zoologically as the Key yellow. It resembles the latter in surface appearance, but is harsher, less compressible, more open in texture, weaker, and less durable. In color it is bright yellow and it lacks the red root and interior of the Key sponge, from which it further differs in its habit of flatter growth. It is less harsh than either the Cuban or the Bahama yellow.

Other localities.-Hippospongia equina elastica is also found in the Mediterranean, where it is known as the horse sponge and otherwise, from Haiti and other places in the Caribbean Sea, and from Australia and New Zealand. Euspongia irregularis pertusa is known zoologically from Ceylon, Australia, and the Ellice Islands in the Pacific Ocean.

\section{VELVET SPONGES.}

The velvet sponges found in the straits of Florida, the Caribbean Sea, and the Bahamas, with the possible exception of the Jamaica sort, appear to belong I to Lendenfeld's Hippospongia equina meandriformis. They are generally cakeshaped or spheroidal in form, somewhat broader than high and usually attached by a moderately broad base from which the sides swell out. The surface lacks the pointed or the edged tufts of the sheepswool sponge and the lamellæ are thickened at their free edges to form rounded or flattened cushions lying in the same plane and imparting a smooth appearance to the sponge. These cushions form either meandering ridges or flat brush-shaped tufts, adjacent ridges being often united by a felting of fibers producing a flat surface.

There are usually two, sometimes one, or three, large pseudoscula or vents on the upper surface. These are subcircular ragged openings, unlike those of any other commercial sponge, divided internally into numerous circular openings by irregular torn-looking septa. The color of the skeleton is light brown or dull yellow.

The velvet sponges are very soft to the touch and well deserve their name, but they are rather less compressible than the sheepswool and absorb water less quickly. They are also less durable and on account of the large holes or vents in the upper surface tear more readily. They are next in value to the sheepswool, though not differing much from the yellow in price. Following are the commercial kinds or grades:

Florida velvet ( $\mathrm{pl}$. XLV).-Found only on the reefs between Key West and Cape Florida, where comparatively few are taken. They are generally rather harsh and more or less torn and irregular. 
Bahama velvet (pl. XLVI).-These bring the highest price, and the best, from near Abaco, are excellent sponges, very soft, of good shape, and moderately strong.

Cuba velvet (pl. XLVII).-These somewhat resemble the Florida sponges and are about equal to them in quality, though softer and frequently with the pads less compact and more tufted or "frizzly."

- Honduras velvet.-The velvet sponges are the best that have been produced, so far, in British Honduras. They resemble the Cuban sponges more closely than those from other localities and appear to be about equal to them in quality. The rollers are hard but attached specimens are usually soft. though not so strong as Bahama specimens.

Jamaica velvet.-This differs much from the other velvet sponges. Its surface is more villous, the lamellæ less swollen on their free edges, and the shape tends to uprightness rather than rotundity, the older specimens especially being decidedly columnar. The most marked difference, however, is in the character of the vents, which instead of lying in subcircular septate depressions are grouped in single or double rows on the summits of branching crests which cross the tops of the sponges. The crests are formed of laciniated tufts somewhat like those which surround the vents or "eyes" of sheepswool sponges, and the individual openings are incompletely separated by ragged partitions as in the other velvet sponges. This arrangement results in a gash or tear more or less completely across the top of the skeleton. These sponges are harsher and otherwise inferior to the other velvet sponges.

Other localities.-This species is also known zoologically from Fernando de Noronha and Mauritius. A few inferior velvet sponges are taken on the Mexican coast but are usually included with the equally inferior sheepswool from that country. The few sponges taken about the island of Gonaves, off the west coast of Haiti, are principally of this species.

\section{GRASS SPONGES.}

Grass sponges are known commercially from Florida, the Bahamas, Cuba, Mexico, and British Honduras. They exhibit great diversity of shape and texture, but are all inferior in quality, lacking in durability, usually harsh to the touch, or, if soft, exceedingly tender. Most of them appear to belong to Lendenfeld's/Hippospongia equina cerebriformis, but it is by no means clear that they are all of this variety or that they can be assigned to Hyatt's several varieties of his Spongia equina. None of the descriptions is sufficiently clear and complete to enable one to assign satisfactorily any large proportion of a considerable series. Following are the commercial varieties:

Anclote grass (pl. XLVIII).-These are the best of the grass sponges, but their shape is such that they are generally used as cuts. They are almost always 
shaped like waste-paper baskets, inverted truncated cones deeply hollowed on their upper faces. The attached base is one-third to one-half narrower than the upper rim, the sides are almost straight or slightly convex, and the interior is hollowed out almost to the base in the larger specimens. The sides are sometimes nearly smooth, but are generally furnished with interrupted vertical ridges tufted at their upper ends, and are perforated by numerous orifices about $\frac{1}{16}$ inch in diameter. There are no oscula on the outer surface, although there are often irregular openings penetrating to the interior or even to the central cavity. The walls are thin at the rim of the vase and thicken toward the base. The oscula or vents are numerous and cover the whole interior of the sponge, excepting the vicinity of the rim. They are about $1 / 8$ to $1 / 4$ inch in diameter and in the skeletons of older specimens are frequently converted into demicylindrical radiating furrows by the breaking down of the walls toward the cavity of the vase.

The skeletons are of a dirty brown color, harsh to the touch and highly elastic and resilient. These sponges are used by manufacturers of explosives, by masons, and for cleaning purposes about machine shops. They are especially useful where there is much oil, as greasy matter is more readily washed out of them than from any other sponge. For this reason, and on account of their harsh, stiff surface, they are useful for domestic purposes in washing pots and pans. They are found distributed over the entire Bay grounds.

Key grass ( $\mathrm{pl}$. XLIX, $\mathrm{L}$, and $\mathrm{LI}$ ).- - These sponges are much more diverse in appearance than the corresponding grade from Anclote, are softer, more compressible, and much less durable. A typical form arises from a short narrow base or peduncle, spreading into a more or less hemispherical massive sponge with a flat or slightly concave top. The whole exterior is nearly covered by thin-walled oscular tubes about $3 / 4$ to $\mathrm{I}$ inch in length, the openings having a diameter of about $\frac{3}{16}$ inch. These tubes are directed variously, sometimes opening almost vertically downward, are sometimes deficient on one side, as in Lendenfeld's Hippospongia canaliculata cylindrica, and are not infrequently branched or $Y$-shaped. In some cases they extend more or less completely over the top of the sponge, but in the skeleton the latter is usually occupied by a great number of closely approximated orifices, about $\mathrm{T} / 8$ inch wide, separated by extremely thin walls, this feature being the principal reason for the great weakness of the sponge. In life this portion is covered by a membrane perforated by extremely minute pores, and even when the tubes extend over the top the space between is covered by a membrane of this character. In older specimens the oscular tubes on the outer surface become shorter and less prominent, though retaining the general characters just described.

In other cases the walls of the sponge become much folded and occasionally lobular, and the outer surface bears pencils, tufts, and vertical ridges of fiber, 
which obscure the oscula and produce a cavernous interior. The walls in this type of sponge tend to become more vertical and the base of attachment broader, and as the top is often concave by the decay of the tissues, the sponge is more like the Anclote sponges, from which it is distinguished by its more irregular surface, its cavernous interior, thicker rim, and greater compressibility and tenderness of fiber, as well as by the presence of oscula on the outer surface. In other specimens the outer walls are smoother, with fewer and less conspicuous oscula, and the tufts of fibers are shorter and more uniform, exhibiting between them numerous small orifices. The whole top of these specimens, excepting a zone at the rim, is perforated by pores of uniform size, like those described in the first variety.

The Key sponges appear to be Hyatt's varieties typica, plana, divisa, and caliciformis, although his descriptions can not be recognized with certainty. The gradations are multifarious.

Bahama grass (pl. LII). - These differ strongly in general appearance from the Anclote and Key sponges and most of them probably, though by no means certainly, belong to Hyatt's variety obscura. They are generally round or cake-shaped and regular and are covered with fibrous tufts and pencils somewhat resembling those of the sheepswool sponge. The oscula are rather numerous, circular, and confined mainly, though not entirely, to the upper surface; but each has its own tube separated from that of its fellows, and there is nothing resembling the sieve-like upper surface of the Key sponges. The oscular tubes are thin-walled, of nearly uniform length in each individual, and the spaces between them are more or less completely filled with an irregular net or loose felt of fibers. In older specimens the soft superficial tufts often almost or quite disappear and the walls of the tubes break down, producing a rough, ragged exterior. The small specimens are light yellow, soft and compressible, the larger ones brown, harsh, elastic, stiff, and weaker in texture. Specimens from Andros Island, which grow principally on sea feathers, are nearly spherical, the oscula are less conspicuous, the surface tufts cushioned or palmate, and the texture weak.

Cuba grass (pl. LIII). - The Cuba grass sponges considered as a whole are intermediate between the Key and the Bahama sponges. In a given lot there are likely to be specimens resembling the plana type of Key sponges and others like the obscura type from the Bahamas with more or less intergradation. In old age the obscura type sometimes becomes cavernous and with a very irregular nodular surface. The quality on the whole is inferior to that of the same grade from the Bahamas.

Honduras grass. -The grass sponges from British. Honduras appear to belong to the obscura type and resemble the coarser and harsher of the Bahaman 
and Cuban sponges. There are occasional soft specimens, but in general they are so hard as to be of little commercial value.

\section{GLOVE SPONGES.}

This is the Spongia graminea of Hyatt, which Lendenfeld in his synonymy includes with certain Australian specimens in his Hippospongia canaliculata, var. flabellum, though the description which he furnishes does not apply, except perhaps as to the character of the fibers.

The shape is never "thickly flabellar," but almost invariably stoutly columnar, the sides being almost vertical and contracted at the top, which is usually flat. The base is almost as broad as the sponge. The appearance of this species is very characteristic, the sides being fluted with irregular vertical parallel ridges between which lie one or two rows of round holes from $i^{1} \overline{6}$ to $i^{3} 6^{*}$ inch in diameter. The ridges are frequently swollen on their free edges, which always bear long, ragged pencils of fibers. When the grooves are deep the ridges become plates, which viewed from above have a radial arrangement. They begin a short distance above the base and extend over the top of the sponge as far as the large open compound vents, which remotely resemble those of the velvet sponge.

Glove sponges are found on the Key and Bay grounds of Florida (pl. LIV) and in the Bahamas. Those from the Bay ground are very poor and are rarely brought in by the spongers, to whom they are known as "bread sponges, "on account of their excessive tenderness. Glove sponges are very soft and elastic, but owing to the weakness of their fiber and their open texture they are almost worthless for commercial purposes. Hyatt states that "this is one of the grass sponges;" hence his name for it, but it is now generally known by the name used here.

The best glove sponges come from Biscayne Bay, where they grow stronger, less open, and with lower ridges than in other parts of the Keys.

\section{REEF SPONGES.}

The few reef sponges taken on the Key grounds in Florida are generally included with the yellow sponges and do not reach the market as a distinct sort. Those found in the trade come from the Bahamas, the north coast of Cuba, and British Honduras, the former two localities producing sponges of essentially the same character, while those from Honduras are inferior, more irregular and open, and with other indications of shoal water origin. Reef sponges are also taken on the west coast of Haiti.

Most reef sponges appear to belong to Lendenfeld's species Euspongia officinalis rotunda, embracing many of Hyatt's numerous varieties of Spongia 
agaricina and $S$. officinalis. As might be expected from this statement, they are of varied shape, but comparatively uniform in quality and the appearance of the surface, which is a fairly even network inclosing numerous small round holes averaging about ${ }_{7^{1}}^{\frac{1}{6}}$ inch in diameter, the interlying ridges being covered with short, bristle-like bundles of fibers. In the general appearance of the surface these sponges resemble the finer grades of Mediterranean sponges much more closely than do any of the other American sponges, but the pores are somewhat larger and the projecting bundles of fibers are stouter and stiffer. In some specimens, particularly the helmet-shaped ones, which are apparently Hyatt's variety disciformis, the surface is softer than that of the zimocca, but not equal to that of the Mediterranean toilet sponge.

Most of the larger reef sponges from both the Bahamas and Cuba belong to Hyatt's Spongia officinalis subsp. tubilifera vars. pertusa and mollis (pl. L,V), not Lendenfeld's Euspongia irregularis pertusa, and are massive lobular forms with the vents at the conical summits of the fistular lobes or the solid masses into which they fuse. In the furrows between the lobes and the depressions between the summits of those which have fused basally, the surface orifices are larger than elsewhere and the projecting bristles are much longer. The vents are generally arranged in more or less radiating rows extending down the sides of the sponge. Another common type is flattened in a vertical plane, with the oscula lying in a sharp crest extending longitudinally up the ends and across the top and surrounded by soft tufts of fiber longer than on the rest of the surface (pl. LVI). Between these two types there are intergradations tending to produce more or less massive forms, with the oscula in rows or scattered on rounded eminences. Others evidently belonging to Hyatt's S. agaricina punclata are considerably higher than broad, and have the oscula more or less radially arranged, those on the sides being slit in the direction of the base. These are often included among the "hardheads." The reef sponges are low priced and are used as desk sponges, for surgical purposes, for infant toilet sponges, especially when bleached, and for various purposes in the arts which require a soft sponge of no great durability.

\section{HARDHEAD SPONGES.}

The hardheads (pl. LVII), most of which come from the Bahamas, British Honduras, Haiti, and the north coast of Cuba, are another miscellaneous group, some of which are indifferently assigned to this or the preceding grade, as they are harder or softer to the touch. The hardheads are generally elastic and resilient, but somewhat less compressible than the preceding and harsher to the touch. They are also on the whole more regular in form.

A considerable number of them, especially among the Cuba specimens, belong to Lendenfeld's Euspongia irregularis pertusa, the larger and softer 
specimens of which are classed as yellow sponges. Most of the others can be assigned to one or the other of Hyatt's varieties which Lendenfeld includes in his Euspongia officinalis rotunda. Common among these are conical or club-shaped forms sometimes bluntly branched (Hyatt's agaricina corlosia var. elongata) or rounded specimens attached by a narrow base (Hyatt's officinalis tubilifera var. rotunda). In both of these the surface is composed of narrow ridges separating small circular apertures and covered with short bristles. The larger of these sponges tend to become conical and somewhat flattened in a vertical plane, and they are also usually softer and more compressible than the smaller individuals. The oscula are large and conspicuous, they usually lie on more or less prominent rounded eminences and at the summits of the blunt branches, and tend to become slit-shape or elongate, especially on the sides. The hardhead sponges are used for applying shoe dressings, as desk sponges and for various purposes in the arts not requiring great softness. They are in general more durable than reef sponges.

\section{WIRE SPONGES.}

The wire sponge (pl. LVIII and LIX), sometimes called "bastard sheepswool," somewhat resembles the wool sponge in superficial appearance, though it more closely simulates the honeycomb sponge of the Mediterranean. In shape it is regular, rather broader than high, and attached by a broad base. The sides are perforated by numerous circular or polygonal orifices, separated by thin-edged partitions which, while sometimes ending in bristly tufts, are never prolonged into the long, soft, expanded processes characteristic of the sheepswool sponge, the surface of the wire sponge therefore lying in a more uniform plane. The oscula or "eyes" are confined to the upper surface, are smaller and more numerous than in the sheepswool sponge, and are rarely or never situated on the summits of cones rising above the general surface.

The wire sponge differs from the honeycomb sponge in its more open surface and general texture, its more bristly appearance, its much thicker fibers, and coarser, more open felt. If the fibers are examined under a lens they will be found heavily charged with sand granules, which impart to the sponge its characteristically harsh feel.

Until very recently wire sponges were rarely brought to market on account of their numerous bad qualities - their harshness, their lack of strength and absorptiveness, and the readiness with which they drain after being wet. Within the last year, however, a considerable demand has arisen, and they now yield the spongers a price per bunch about on a par with that of yellow sponges. They are all exported, and there is good reason to believe that they are bleached and sold as Mediterranean honeycomb. They come almost entirely from the west coast of Florida. 


\section{TURKEY CUP SPONGES.}

These sponges (pl. Lx and LxI, fig. I), known also as fine Levant or fine Syrian, are the Euspongia officinalis mollissima of Schulze. They are sometimes massive, when they are known to the trade as "Turkey solids," but are frequently more or less cup-shaped, though perfect cups are comparatively rare, and as they are regarded as especially desirable bring high prices. The oscula are comparatively large and numerous and are grouped closely together on the upper surface of the solids or in the concavity of the cups, the skeletal partitions which separate them being often very thin. The outer surfaces are perforated by numerous round or polygonal pores, the narrow partitions between which are beset with long, slender, and very soft, fibrous pencils. The foreign bodies in the fibers are small in quantity, the main fibers themselves are comparatively few, and the microscopic network has rather large irregular and elongate meshes, this combination of characters making it the finest and softest sponge and one of the most elastic on the market.

The "Turkey cup" and "Turkey solid" are confined mainly to the eastern Mediterranean, though a closely related form comes from Zarzis, on the Tunisian coast. The very finest are obtained on the Syrian coast, but excellent qualities are found at Crete, Cyprus, and Mandruka in Egypt. It is stated that many of the best now come from caves and crevices, where they attain a finer and denser growth than elsewhere. This kind of sponge, like the Turkey toilet sponges, never attains a size comparable with that reached by most other commercial sponges, but the high price it brings compensates for its smallness. It is stated that a few of the very best sell for about $\$ 50$ per pound. They are used mainly for the more exquisite purposes of the toilet.

\section{TURKEY TOILET SPONGES.}

These sponges (pl. LxI, fig. 2, and LXII) are mainly included in the zoological variety Euspongia officinalis adriatica of Schulze, though apparently some inferior specimens of the Turkey cup spongé are also embraced in this commercial species. Toilet sponges are flatter and more encrusting in their habit than are the cup sponges, and are generally broadly attached, though sometimes the base is constricted. The oscula are confined to the upper surface, being usually distributed over all parts excepting toward the edge, but in what appear to be compound individuals they are often arranged in groups. Each oscule is generally surrounded by a rampart of bristles. The surfaces other than those bearing the oscula are perforated by numerous fine pores. The ridges forming the network between these pores are rather sharp edged as compared with the cup sponges, while the fibrous processes which they bear are shorter, stouter. harsher, and more bristle-like. The sponge as a whole is less compressible than the cup sponges and not so soft and fine. 
Toilet sponges are rather generally distributed in the Mediterranean from the Adriatic and the coast of Tunis eastward. They are used for toilet purposes, in surgery, and for leather dressing, pottery making, and various other purposes of the arts.

A somewhat similar sponge is found in great abundance at Sitanki, Philippine Islands. (Pl. LXIII.) Its general texture closely resembles the toilet sponge, but its upper surface bears longer tufts of fibers and numerous uniformly distributed oscula or pores about one-eighth inch in diameter, characters which cause it to resemble in that respect some of the grass sponges from the Florida Keys. It is very soft, but much weaker than the toilet sponge and about as strong as Key grass. ${ }^{a}$

\section{ZIMOCCA SPONGES.}

These sponges (Euspongia zimocca) are massive, more or less conical, broader than high, sometimes flat on top, sometimes concave, occasionally cupshaped, and usually attached by a rather small base. (P1. L.XIV.) The oscula are scattered over the upper surface, occasionally arranged in irregular radial rows, and are frequently, though by no means always, surrounded by ramparts of bristly fibers. The whole outer surface consists of a reticulation of narrow ridges, inclosing numerous small pores and bearing short fibrous villosities which generally become longer and softer toward the upper surface. The surface texture of the skeleton resembles that of some of the Cuban and Nassau hardhead sponges, but the orifices are smaller, the intervening ridges are narrower, and the skeleton softer and more durable.

The zimocca sponge is found commercially in the Adriatic, the Dardanelles, on the west coast of Asia Minor, the coasts of Egypt, Tripoli, and Tunis, the islands of the Grecian Archipelago, Crete, Cyprus, Corsica, and Lampedusa. The zimocca sponges are the harshest of the Mediterranean grades, but in common with other kinds they become softer when bleached, though they are less durable. Both bleached and unbleached they are darker in color. They are used for toilet purposes, and by potters, leather dressers, and other artisans. They are generally too harsh for surgical purposes.

Seale describes a sponge which on the advice of a New York dealer he calls a "Philippine zimocca." The specimen shown to me was of excellent quality and commercially valuable, but was certainly not a zimocca sponge.

HONEYCOMB, BATH, OR HORSE SPONGES.

These are the Hippospongia equina elastica of Lendenfeld and are classed by zoologists with the yellow sponge of the Florida Keys, from which it differs

${ }^{a}$ I have recently seen one of these, in a good state of preservation, which has been in daily use for bath purposes for two years. 
in shape, texture, strength, and softness. (Pl. LXV.) It is a massive, cakeshaped sponge, attached by a broad base, always broader than high and never "pineapple-shaped" as its American relative frequently is. The surface is fairly uniform, with the lamellæ superficially expanded and often forming narrow reticular bridges across subsurface cavities. The surface is covered with small rather blunt tufts or pencils of fiber, particularly around the edges of the numerous polygonal, circular, or meandering openings. The oscula are scattered over the upper part of the sponge, usually opening on the general surface, but occasionally surrounded by a rampart of fibers which produce a very short oscular tube. The general superficial aspect of this sponge is intermediate between the sheepswool and the velvet, being much less shaggy than the former and rougher and less meandriform than the latter. In surface appearance it somewhat resembles the Florida wire sponge. Certain sheepswool sponges which the author has artificially grown from cuttings in the Florida Keys reproduce quite accurately the surface texture of the honeycomb sponge.

The honeycomb sponge is quite generally distributed throughout the Mediterranean, being found from the Gulf of Lyons along the north, east, and south shores as far as the Algerian coast. It is known commercially from the vicinity of Marseilles, Corsica, the Adriatic, the Archipelago, the coasts of Asia Minor, Egypt, Tripoli and Tunis, Crete, Cyprus, Lampedusa, the Dardanelles and the Red Sea. The best are the Mandruka sponges, which are compact, soft, and fine, but those from Tunis, Crete and Asia Minor are little inferior and many of them enter the markets as Mandrukas. The Tripolitan honeycomb sponges are rough, coarse, and loose in texture, and those from the Archipelago are but little better.

As has been before stated, one of the yellow sponges of American waters is considered zoologically identical with the honeycomb, and the variety is also known from Australia and New Zealand, those I have seen from the former locality being harsh, open, coarse, and decidedly inferior to any known commercially.

As compared with American sponges, the Mandruka is softer than any except the Matecumbe sheepswool, but it is less durable than the Rock Island sheepswool, less resilient, and more quickly loses its elasticity in use. It is a popular bath sponge, for which its size and shape makes it excellent, but is being displaced in the American markets by the more generally superior sheepswool. These sponges are also used in the arts, by jewelers and silversmiths, leather manufacturers, and as desk sponges for bank tellers, etc.

ELEPHANT-EAR SPONCES.

These are the Euspongia officinalis lamella of Schulze and are either cupshaped or cap-shaped with rather thin walls of uniform thickness or a more or 
less rolled ear-shaped or fan-shaped plate from $\mathrm{I} / 2$ to $\mathrm{x}$ inch thick. (Pl. LXVI.) The oscula are confined to the inside of the cupped forms or the concave faces of the lamellate specimens, and are arranged in groups of 4 to 6 , surrounded by tufts of fibers longer than on the rest of the skeleton. These groups are generally in radial and concentric rows and the whole of the oscular surface of the skeleton often has more or less the appearance of being radially grooved, owing to the linear arrangement of the rows of fibrous tufts which cover it. The outer or convex surface of the sponge is more uniformly covered with soft fibrous tufts, though these tend to radial arrangement near the rim, and there are sometimes radial ridges or thickenings of irregular length extending from the base toward the margin. This sponge is very fine, soft, and durable, being equal in those respects to the Turkey toilet sponge. It is used for fine toilet purposes, for which its shape makes it desirable; for surgical purposes, and in the medical application of electricity, by potters, fine leather workers, jewelers, cane makers, hatters, and other artisans requiring a smooth, fine, soft, and durable sponge.

It is found commercially on the coasts of Provence and Dalmatia, in the Greek archipelago, on the coasts of Egypt, Tunis, and Algeria, and about the Balearic and Lampedosa islands, and the variety is known zoologically from the north coast of Australia.

A similar but much denser and harsher sponge is found near Jolo, Philippine Islands. In the few specimens that I have seen the fibers are heavily laden with sand grains, which makes them useless commercially, but it is possible that better grades may be found.

\section{THE FLORIDA SPONGE FISHERY.}

The Florida Keys first received permanent settlement about the time that the present State was erected into a Territory upon its cession to the United States in 1821. Key West, the first and for many years the sole center of the sponge industry, was settled in I822, and it is probable that the early inhabitants soon learned, from the specimens thrown up on the beaches of the keys, of the presence of several species of useful sponges in the surrounding waters. It is known that long before these became an article of commerce they were in limited domestic use among the inhabitants, but it was apparently not until I 849 that they were given a commercial value. In that year a cargo of sponges was sent to New York on a venture, probably as the result of knowledge of the recently discovered commercial value of the sponges in the Bahamas, which islands furnished the majority of the early settlers of Key West and have since maintained with it close social relations. Before this time the entire sponge supply of the United States was derived from the Mediterranean, though of later years a few sponges may have come from the Bahamas, which had begun to export seven or eight years 
before, but that the supply from the latter source must at most have been small is shown by the fact that its total exports to all countries in the year mentioned were valued at but some $\$ I 0,000$. In any event, sponges other than those from the Mediterranean were but little known and the venturesome cargo from Key West narrowly escaped being thrown away as worthless. Its ultimate sale, however, established a market for this newly discovered product of the keys, and several merchants at Key West began to buy the better grades and to take them in trade. It is said that at first the price was but io cents per pound, presumably for sheepswool sponges, but as the quality of the domestic product became better known the price improved, there began to be a systematic investment of capital to take the place of the desultory fishery previously carried on, and a class of men developed whose principal or sole business and means of livelihood was gathering sponges.

\section{THE SPONGING GROUNDS.}

The sponging grounds as at present developed are broadly divided into two widely separated areas, the "Bay Grounds," lying in the open waters of the Gulf of Mexico, from about Johns Pass to St. Marks, and the "Key Grounds," stretching along and among the reefs and keys from Cape Florida to Boca Grande Key.

That there is sponge-bearing bottom between the New Ground off Cape Sable and the mouth of Tampa Bay admits of little doubt, but notwithstanding that the Key West fleet has traversed that region year after year in going to and from the Bay grounds, practically no sponges have been taken there, owing mainly to the depth and almost constant turbidity of the water. A few spongers have reported seeing sponges, but never in considerable quantities.

The grounds as exploited and worked by the hookers up to the time of the introduction of diving apparatus, in April, 1905, covered an area of 4,350 square miles, of which the Bay grounds contained about 3,400 and the Key grounds about 950 square miles. It must not be considered, however, that all of. this area is productive, for on the contrary the actual sponge-producing bottom in any given field is far less than the barren areas with which it is mingled.

Sponges grow neither on sand nor mud, nor primarily on grassy areas, but must have some firm clean body to which to attach when the small free-swimming larva is ready to settle down and assume its final fixed condition and form. Among the Keys the bottom in the main consists of sand and more or less calcareous mud or marl, either naked or less frequently supporting a grassy growth, while on the Bay grounds it is generally sandy offshore with more or less grass in the shallow waters close to land. In the channels and other places among the keys where the currents run with sufficient velocity to scour the bottom or the waves prevent the excessive deposit of silt, the coral rock is exposed and furnishes 
attachment for sponges and other sessile marine organisms. In the same way on the Bay grounds the bottom is denuded by currents in the channels, as at the north end of Hog Island, and on the Buoy grounds above Anclote Key, while offshore there are rugged outcroppings of rock rising above the surrounding sand. It is upon these "spots of bar," as the spongers call them, insignificant in area as compared with the adjoining stretches of sand and mud, that the sponges occur in greatest abundance, attached to the rocky floor of the sea.

Occasionally they grow on sea feathers, which in turn are anchored to the bottom, or on mangroves, and considerable numbers are often found in the grass or in saucer-shaped sandy depressions surrounded by grass. Their occurrence in the latter places apparently contradicts the statement that they do not grow on grass or sand, but the contradiction is apparent rather than real, as they have been in all cases originally attached, but either in the operation of sponging or by wave action have been torn loose, and rolling freely over the bottom at the mercy of the waves have finally been entrapped in the tangle of vegetable growth. Such sponges are generally almost spherical, have no "root," and the surface is uniformly smooth from friction on the bottom and harsh from the excessive inclusion of sand grains. They are known to the spongers as "rollers" or "rolling johnnies" and are often found in groups in sandy depressions in grass.y bottom called "turtle sets" from the erroneous supposition that they are made by turtles.

\section{BAY GROUNDS.}

The Bay grounds, which formerly held a secondary place commercially, now yield practically the entire production of Florida sponges, the Key grounds furnishing hardly 9 per cent of the sheepswool sponges and less than 13 per cent of all kinds. The Bay grounds begin at or near Johns Pass, a few miles north of Tampa Bay, and extend without material interruption as far as St. Marks, a distance of 160 miles. As known at the time of the introduction of the diving machine, this ground extended from a depth of Io or I 5 feet to from 7 to I2 fathoms 20 to 40 miles from shore, but although sponges had been seen in the greater depths, no sponging had been done in more than 8 fathoms owing to the limitations imposed by the methods employed. Grass and a few sheepswool sponges were taken in less than Io feet of water, especially in the early days of the fishery, but the bulk of the product was from between 20 and 35 to 40 feet, though in I902, owing to unusually favorable conditions, a heavy catch of fine sponges was made in water as deep as 45 or 48 feet. Several persons had reported seeing sponges in 20 fathoms, and it is stated that on at least one occasion a sponge was brought up from i f fathoms on a fish line.

In 1905 the area of the known sponge beds in the Bay grounds was about 3,400 square miles. Since then the operations of the divers, who in a few cases 
have gone as deep as i I o feet, have slightly extended this area, and as that method of sponging becomes older and the shoaler waters more exhausted it can hardly be doubted that other productive grounds will be found in the greater depths. Should the Bay grounds be found to extend generally to a depth of 15 fathoms, about 3,700 square miles would be added to the area of sponge bottom, while if they prove productive to a depth of 20 fathoms there would be added to the area developed by the hookers no less than 5,900 square miles, making a total of about 9,300 square miles of sponge-producing bottom between Johns Pass and St. Marks inside of the 20 -fathom curve.

It must of course be understood, as before intimated, that this area is not all productive. In general, the sponges are confined to the "barry bottom," which rises in patches like rocky islets above the sands that cover the general floor of the Gulf (pl. xxvirI). These bars are always more or less scattered, here isolated, there occurring in groups or series of ridges, and in the operations of sponging much time is consumed in looking for them. In the deeper waters they are found with the lead and in the shoaler waters by searching the bottom with the water glass or water telescope.

The bars, especially in the shoaler water, are sometimes moderately level expanses, but are generally rough and rugged, with fissures, clefts, crevices, miniature precipices and overhanging ledges, in all parts of which the sponges grow like lichens clinging to the rocks, sometimes exposed to view from above, often hidden in semidark recesses on the sides of upright walls or beneath projecting ledges. They are mingled with noncommercial sponges of many species, with gorgonians (sea feathers, etc.), polyzoa (sea moss), and corals, and surrounded by a wealth of life-fishes, mollusca, crabs, shrimps and other crustacea of bizarre shapes and brilliant hues, starfish and sea-urchins of varied form, sea cucumbers and worms, some permanently attached to the rocks and others free to wander, yet finding on the bars rich feeding grounds, oases in the vast desert of sand lying round about.

Compared with the total area of the sponge grounds the extent of these bars is small, nobody can say how small relatively, but it is from them and practically from them alone, that the supply of sponges must be drawn. Their distribution is irregular in different sections of the grounds and in different depths; sometimes there are great areas of white sandy bottom quite devoid of rocks and again the bars are comparatively closely approximated over a wide range.

The Bay grounds are broadly subdivided by the spongers into the Rock Island, Pepperfish, New, St. Martins Reef, Anclote, and Highland regions, each in itself of uncertain boundaries and more or less subdivided into indefinite sublocalities. The names used by the spongers are very contradictory, and the location of a fleet working in a given area may be described in five or six different 
ways by hardly more than that number of masters. The reasons for this are twofold. In the first place the local distinctions between the grounds are purely artificial, as the sponge-bearing belt is practically continuous, bearing in mind the irregular distribution of the bars themselves, and in the second place the spongers when out of sight of land do not know exactly where they are, few if any being navigators. They usually refer their location to their last point of departure and it may thus happen that of two vessels working side by side one will declare itself off Rock Island and the other off Pepperfish Keys, the two locations being over 40 miles apart, the first vessel having sailed south and the other west from the last landfall.

Though the grounds as at present known to the spongers are indeterminate as to their boundaries, there were originally apparently natural distinctions between some of them. The shoal-water areas were first discovered and worked and there it was found that the sponge-bearing bottom was interrupted by large areas of smooth barren sand and grass. One of these, lying off Piney Point, separates the inshore parts of the Rock Island and Pepperfish grounds, and another and larger one, extending for 30 miles opposite Cedar Keys and the mouth of the Suwanee River, lies between the Pepperfish and St. Martins Reef beds. Each of these extends to a distance of 20 to 25 miles from shore and to a depth of 5 to 8 fathoms. Later discoveries developed bars outside of these "lakes" as they are called, so that in the deeper water the grounds are now continuous.

The most prolific beds extend from off Cedar Keys to the waters southwest of Anclote, including New, St. Martins Reef, and Anclote grounds. About r895 the sponges on the Rock Island, Pepperfish, and New grounds were killed off by "poison water," which extended from the vicinity of St. Marks to the beds off the Suwanee River. Recuperation of the beds first began to make itself evident about igor.

Rock Island region.--The region so designated takes its name from a small island about 22 miles to the eastward of St. Marks light. It extends from about Ocklockonee shoal to the smooth sandy bottom off Piney Point, which separates it in its shoaler parts from the Pepperfish Key beds. As developed by the hookers, it had an area of about 800 square miles, about 50 miles of which, forming a strip a few miles offshore, yields grass sponges in considerable numbers. Inside of the 5-fathom line the Rock Island beds produce shcepswool sponges in great abundance, though most of them are comparatively small. When first discovered, the sponges were larger; but owing to the intense fishery in the shoal waters they now have no opportunity to grow, if, indeed, their size has not become permanently impaired by the persistent and constant selection out of the larger ones, as appears to be the case at Sugar Loaf Key also. 
The sheepswool sponges of this region are of fine quality, close and tough of fiber, rather flat or cake shaped, and somewhat darker in color than the Key sponges. They bring a higher price than any American sponges, though probably not superior to those from other sections of the Bay grounds, the product of all of which goes under the general designation of "Rock Island."

Pepperfish Key region.-These beds lie opposite Pepperfish Keys and extend from the sandy bottom off Piney Point and Grass Island to the similar, though larger, area off the Suwanee and Cedar Keys. In the deeper water they join the Rock Island beds on the one hand and the New ground beds on the other. They lie in a depth of from 6 to 7 feet to io or I I fathoms, beginning about 3 or 5 miles from shore, and extend a distance of about 25 to 35 miles. Their total area in 1905 was about 550 square miles, of which about 75 square miles, lying in a depth of from 8 to 18 feet, was mainly productive of grass sponges.

New Ground region.-The New ground is so called because it was discovered at a later period than those on each side, Pepperfish and St. Martins Reef, between which it formed a connecting link in the deeper water outside of the sandy area, which separates them shoreward. Its extent northwest and southeast is about 30 miles, lying in sinuous outline in a depth of between 5 and ro fathoms at the stage of development of r905. Its width varies, but averages a little over ro miles, and its area as exploited by the hookers is about 350 square miles. This is a prolific ground and, in the opinion of the hookers, marks the northern limit at which the sponges are at present most abundant.

Withlacoochee Bight and St. Martins Reef.--This includes the sponge beds between the mouth of the Waccasassa River and Sea Horse Reef on the north and St. Martins Reef on the south, covering an area of about I, IOO square miles. As developed by the hookers, the beds ranged from a depth of about 7 or 8 feet to 9 or Io fathoms; but the divers have since found the productive bottom to extend in some places to 15 or 18 fathoms.

Withlacoochee Bight is prolific in sheepswool sponges, but owing, perhaps, to the discharge of the numerous small streams along shore the water is generally too cloudy for the hookers to work to advantage. In the shoaler water, from $\mathrm{I}$ to 3 fathoms deep, extending along the inner edge of these grounds for almost their entire length, there is an area on which grass sponges predominate, and some years ago many fine large ones were taken there; but it is stated that the growth now consists almost wholly of small specimens. In the deeper water sheepswool and yellow sponges predominate, with a considerable number of large grass sponges. This region and the grounds to the southward are those now principally resorted to by the divers.

Anclote region.--The Anclote region, practically continuous with the preceding and the following, extends from St. Martins Reef to about Big Pass, 
and as known in 1905 covered an area of about 290 square miles. At that time the depth in which the sponges were found extended from about 4 or 5 fathoms to about 8 to Io fathoms; but the divers have since then taken large quantities in from Io to I 5 fathoms, and a few boats are said to have worked as deep as 18 fathoms. There are a few small patches of bar in waters as shoal as 2 or 3 fathoms on the Buoy grounds, in the channel south of Anclote Key and near the north end of Hog Island. The Buoy grounds are noted for their rapid recuperation. The deeper waters produce a fine grade of sheepswool sponges, and both yellow and grass are also found in considerable quantities.

Highlands region.- This, the southern limit of the Bay grounds, stretches from Big Pass to Johns Pass, the known distribution of sponges in 1905 covering an area of about 300 square miles. Owing to the absence of streams discharging fresh water, the sponges extend much closer to shore than in the regions to the northward, but they range offshore to about the same depths as in the Anclote region, though, owing to the steeper slope of the bottom, the hookers never worked so far from shore.

\section{KEY GROUNDS.}

The Key grounds, though for many years the only source of supply of Florida sponges, are now comparatively exhausted and of reduced value. During the past few years they have produced about 30,000 pounds of sheepswool sponges per annum, while in 1900, an exceptionally good year for these grounds, the catch was 58,294 pounds. The production of all kinds averaged 79,487 pounds in the years 1906, 1907, and 1908, while in I899 and I900 the average was 139,458 pounds.

Between the keys and the mainland the grounds extend from Boca Grande Key and Cape Sable as far as the Cowpens, off Long Island, and from the lower end of Cards Sound to Cape Florida. In Hawk Channel there are patches of sponge-bearing bottom along the line of reefs forming its outer margin, and at intervals close to the keys which define it on the landward side, from near Key West as far as Hillsboro Inlet; but, though at one time fished throughout the entire distance, it is only between Knights Key Channel and Soldier Key that these patches now attract the attention of spongers.

The interruption in the distribution of sponges inside the line of keys from Long Island to Cards Sound, mentioned above, is due to the low salinity of the water. For nearly 30 miles Key Largo imposes an unbroken barrier against the interchange of waters between the inside bay and Hawk Channel, with the result that the drainage of the Everglades is impounded and the salinity reduced below the degree which inhibits sponge growth. On two occasions I have run a line of salinity observations through this barren area 
and found the density gradually falling from about $\mathrm{I} .0205$ on the sponge grounds at either end to about r.or 35 approximately midway between. All other conditions for the maintenance of sponge life appear to be present, and certain species, like the loggerhead, more tolerant of fresh water, are found in abundance. In the construction of the new line of railroad to Key West many of the passes between the keys west of Key Largo have been completely or partially closed and it is not improbable that the salinity of the water will be so lowered as to affect adversely the sponge grounds near the Matecumbes.

The Key grounds produce sponges in greater variety than the Bay grounds. Not only are there more noncommercial species but there are more useful kinds, and of each of these there are a number of local varieties readily recognized by the spongers and dealers. All have, however, one well-marked characteristic that in general serves to distinguish them from corresponding species taken "up the bay," namely, a reddish or rusty appearance of the interior fibers, called "red root" on account of its being more readily seen on that portion of the sponge torn away from its attachment to the bottom. This color is not generally exhibited by the strictly peripheral fibers, but is readily observable in the oscula and at the bottoms of the channels or grooves which traverse the surface, and upon cutting the sponge it is found to permeate the whole interior. It is due to an oxide of iron and is popularly supposed among those engaged in the business to be caused in some manner by the coral rocks to which the key sponges are commonly attached. That it is due to the constituency of the water among the keys there can be no doubt, but that it is not absorbed directly from the rocks is shown by its presence in sponges growing above the bottom attached to sea feathers (gorgonians) or artificially grown from cuttings attached to suspended wires. Red-rooted sponges are almost invariably more tender, weaker in fiber, and less durable than those of generally similar texture not so colored, but whether the coloring material causes the weakness or whether the conditions producing the two are merely coincident can not be stated. The color is quite different from the paler yellow seen in some of the Bay sponges.

The "barry bottom" of the Key grounds is generally fairly level as to surface, though on the reefs and in places on the Key shore of the Hawk Channel there are bowlders and heads of coral rock, often rising from a depth of 2 or 3 fathoms almost or quite to the surface. The commercial species found on the Key grounds are sheepswool, yellow, velvet or boat, grass, and glove. The velvet or boat sponge is obtained principally from the reefs and owing to the difficulty of working in that exposed region is to be had in but comparatively small quantities. The other species are generally distributed.

The Key grounds are subdivided into innumerable more or less poorly defined areas, each of which has received from the spongers one or more local 
names, sometimes fanciful, but frequently having some topographic, personal, or historic origin. It is impossible to describe within reasonable limits all of these various sublocalities, but a few of the more important will be mentioned.

The New grounds extend from Cape Sable and Middle Cape southwest to beyond Contents Keys and westerly from a depth of I I feet to a depth of about 5 fathoms. The bottom consists of a series of more or less extensive bars separated by white sand, and the sponges produced are of excellent quality, generally pineapple-shaped and colored less brightly red than is usual in the keys. All classes of sponges are found, but the water is rarely clear and the grounds are therefore but occasionally productive. Southeast of this are "spots of bar" stretching to the so-called lakes along the line of keys as far as Lower Matecumbe.

West of Key West there is an area lying between Boca Grande, Man, Woman, and Mullet keys and the slope of Lavinia Bank, where most of the sponges are rollers. There are also beds along the sides of Northwest Channel, one of the entrances to Key West Harbor.

Between Key West and Bahia Honda.-In this region sponging has been carried on for many years in Wall Key Lake, Johnson Key Lake, Sugar Loaf Sounds, and in all of the long narrow channels leading between the keys. In the lakes and sounds schools of fish and in the channels the strong currents keep the water muddy a large part of the time. Sheepswool, yellow, grass, and glove sponges are found, but the quality of the first two is inferior.

Money Key and Pigenn Key lakes.-These areas are practically continuous and lie between Bahia Honda and Knights Key Channel, extending north and northwest to Teakettle and East Bahia Honda keys. The water has a maximum depth of about 9 or ro feet in the former and I I or $\mathrm{r} 2$ feet in the latter. Wool, yellow, grass, and glove sponges are found, the former being superior in quality to those found to the westward.

Knights Key Channel, Rachel Key Lake, Grassy Key Lake, and Channel Key Lake.-These form a practically continuous sponging ground between Knights Key and the sand banks and shoals running northwest from Long Key, and in the palmy days of the key fishery were much resorted to by the Key West fleet. During recent years, in common with the rest of the key grounds, this area was nearly exhausted and comparatively deserted by spongers, but in the spring of 1908 and the following winter excellent sheepswool sponges of good shape, size, and quality were being taken in the vicinity of Bamboo Key. They were described by dealers as being of the highest quality of Key sponges and unusually free from the objectionable red color before mentioned, and the spongers stated that there was an abundant young growth on the grounds. This appears to be an evidence of the natural recuperation of the 
sponge beds when, either by legal prohibition or from commercial considerations, they are wholly or partially abandoned for a few years. On most parts of this area the barry bottom is scattered and the water, which has a maximum depth of about ro feet, is frequently too muddy for work.

Jewfish Bush lakes.-These, known respectively as the upper and lower lakes, stretch from Jewfish Bush and Lower Matecumbe Key northwest to Schooner Bank, and produce limited quantities of excellent Key sheepswool. The bars are scattered and of comparatively small extent, and, particularly in the upper lake, the sponge growth is mingled with sea feathers and many kinds of noncommercial sponges. The water varies in depth between 6 and Io feet, the deeper water being toward the northwest.

In the summer of 1908 the sponge beds in this region and to the eastward were destroyed by "poison water." It is probable that this was fresh water from the Everglades, impounded by the railroad embankments of the "Key West Extension." The closure or partial closure of the several channels between the keys must result in the westward extension of the same density conditions which formerly prevented the growth of sponges inside of Key Largo, to which reference has been made before.

Lignum-Vite and Cotton Key lakes. - These lie north of the Matecumbes and Lignum-Vitæ Key, are connected by Ironwood Channel, and almost surrounded by sand banks. The bottom of the former is almost all hard, and bears a scattered growth of sheepswool sponges and considerable quantities of other species. In Cotton Key Lake the rocky bottom is scattered and the growth consists mainly of grass sponges. In Lignum-Vitæ Lake the depth is generally between 6 and 8 feet, while in Cotton Key Lake it averages about a foot less. The sheepswool and yellow sponges from these and the two lakes previously mentioned are the softest produced in Florida, making them especially desirable for bath purposes; they are known to the trade as "Matecumbe," wool and yellow.

The Cowpens are at the eastern limit of sponge growth inside the keys west of Cards Sound. They produce few sponges, and those found are usually rollers on the soft bottom.

Biscayne Bay-Cards Sound, which lies west of Biscayne Bay, contains a few yellow and grass sponges and an occasional sheepswool, but has never been of importance. There are also a few grass and yellow sponges scattered over Cutters Bank, which lies between the two bodies of. water.

Billies Lake, which lies in the southern part of Biscayne Bay between Cutter and Featherbed banks, contains a scattered growth of sheepswool, yellow, grass, and glove sponges, and it is stated that in that portion nearest Sands Key, which is at present the most productive, the growth was at one time prolific. It is probably now restricted by the number of small boats which 
for years have resorted to the locality. Featherbed Bank Lake lies in the deeper water between Featherbed Bank, Ragged Keys, and Black Ledge. Small patches of bar scattered over this area in from 7 to i 2 feet of water produce limited quantities of sheepswool and yellow sponges and large numbers of grass.

Soldier Key Lake comprises all of the remaining sponge-producing area of Biscayne Bay lying between Ragged Keys, Black Ledge, and Cape Florida Channel. Most of the sponges are found in the eastern part, near the extensive banks which separate the bay from. Hawk Channel, but the work of sponging is much interrupted, owing to the general muddiness of the water. Formerly large quantities of sheepswool and especially grass sponges were taken here, but owing to overfishing their numbers are much reduced, though there is no doubt that they still exist in considerable quantities in those places which least frequently clear. The sponges of Biscayne Bay are generally loose, "frizzly," and inferior, and are therefore not highly valued in the markets.

Hawk Channel. - The westernmost bed frequented by the spongers lies off Pigeon Key. Sponges in commercial quantities are found off the Sisters, at Duck Key, Long Key, Lower Matecumbe, from Upper Matecumbe to Tavernier Creek, between Tavernier and Rodriguez keys, off Key Largo, between Key Largo and Old Rhodes Bank, at Old Rhodes Key and at Ragged Keys. North of here they extend as far as Hillsboro Inlet, where the reefs cease, but are now never fished. Sheepswool, yellow, glove, and grass sponges are taken on all of these beds. Velvet or boat sponges are found along the inside of the reefs from the vicinity of American Shoal to Fowey Rocks, and they are not known to occur in commercial quantities at any other place in Florida. As they are not particularly abundant or valuable and as the water in their habitat is generally rough, few of them are taken.

HOOKING.

At first the fishery was carried on by wading in the shoal waters in the immediate vicinity of Key West, especially to the eastward, the sponges being pulled by hand. Later the sponge hook was introduced, originally a two-tined sharp hook attached to a pole of moderate length, but latterly the number of tines was increased to three, the type now universally employed (text fig. I). With the introduction of this implement slightly deeper waters were explored, the fisher standing in the bow of his boat closely scanning the bottom for sponges and tearing them loose with his hook as discovered. To calm the ripples which interfered with their vision the spongers soon learned to make use of oil, and that extracted from the livers of nurse sharks was found to be the best, as it forms a tenacious film and at the same time spreads over a wide area of water. Thin, light oils are ineffective, as they are speedily dissipated and fail to quell the ripples in even a gentle breeze. The oil is usually carried in a wide-mouthed 
bottle and is sprinkled on the water in small quantities by means of a stick or swab, the sponger drifting with the "slick," poling back and forth so as to cover its entire breadth.

This method of sponging is still followed in the vicinity of Key West and among the keys where the depth does not exceed 5 or 6 feet, two or three men, each with a dingey, cruising about on little sloops, cooking, sleeping, living, and to some extent curing their sponges in the most contracted of quarters. They usually build small, frail "crawls" of a temporary character, to which they return each night while in the vicinity, or else the whole product of the trip is carried back to Key West, often in a most unsavory condition, and "crawled" at that place. This fishery is now generally followed only during the winter months, when the more profitable deep-water fisheries can not be prosecuted on account

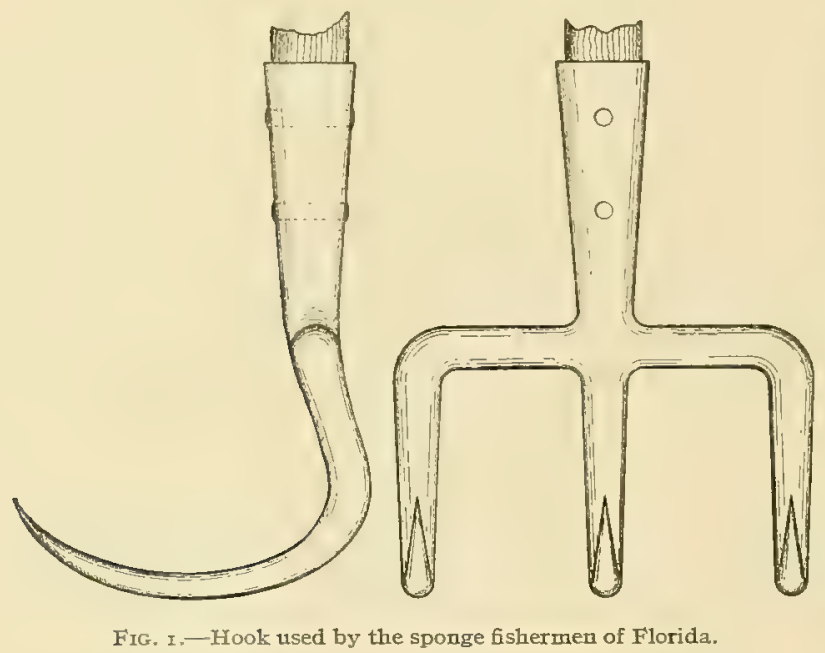
of the weather, or at other seasons of the year by the less skilled spongers, by persons temporarily out of other employment, or by the local residents of the keys. It is prosecuted mainly on the Key grounds as far as the Cowpens and its product is small.

With the growtli of the demand for sponges and the depletion of the beds nearer Key West, the search for other grounds carried boats farther and farther away until the Matecumbes were reached. Here it was found that the sponge growth inside the keys came to a more or less abrupt limit, but along the northwest shore of Hawk Channel, between the keys and the reefs, the workable beds were found to extend as far as Norris Cut, a few miles north of Cape Florida. In 1879 this appears to have been the known extent of the Key grounds, as is shown by a chart of about that date prepared during the canvass for the Tenth Census. Few inhabitants then lived on the shores of Biscayne Bay and the beds in the waters within that bay and Cards Sound, if known, were rarely if ever worked, although soon after that time they were extensively resorted to by the Key West fleet, which found sheepswool sponges of rather inferior quality and especially grass sponges in large quantities. The sponge grounds were also found to extend, along the reefs as far as Hillsboro Inlet, but owing to the prevalence of heavy/ seas on this part of the coast they were not extensively exploited. 
With the extension of the fishery into the deeper waters of the channels and some of the "lakes," as the spongers term the broader expanses between and behind the keys, the old method of sponging became inadequate. Poling became laborious if not impossible, and, moreover, a man standing upright in the boat was unable to see the bottom with sufficient distinctness. To overcome this difficulty the "sponge glass" or "water telescope" was introduced, at first a square wooden box or tube with a pane of glass in one end, but afterwards an ordinary wooden pail with a glass bottom substituted for the wood. The device is said to have been employed first about 1870 or a little before, and correlated with its use came other changes. It was now necessary to have two men in the boat, one to propel it and the other to search for and take the sponges. The skiffs and miscellaneous small boats previously employed were displaced by the present type of dingeys, yawls about if or I 5 feet long and about $4 \frac{T}{2}$ feet beam, light, strong, and handy, with a sculling notch at the stern. The latter is an oak board notched at the top, sometimes fixed but frequently sliding between guide pieces so as to be removable when the boats are hauled aboard the vessel.

Large vessels also came into use, especially after the development of the fishery on the Bay grounds, where the work is carried on often at a distance of 20 to 30 miles from shore. The smaller vessels, many of them under 5 tons, are employed among the keys where shelter in case of bad weather is usually close at hand. The registered vessels range from 5 to about 50 tons, most of them being under $\mathrm{I} 5$ tons measurement. The majority are rigged as schooners, but many of the smaller ones are sloops, as are practically all of the boats measuring less than 5 tons employed in the fishery among the Keys. Practically all of the boats and most of the vessels have been built at Key West, but some, especially the larger ones, have come from other places.

In the boat fishery from one to five men constitute the crew, the usual number being about three. A man working by himself must confine his operations to poling in shoal and smooth water, but two or more men, if occasion demands, may work in rougher and deeper water by using the water glass. The vessels carry crews of from 5 to I 3 men, according to size, the usual number being about 7 or 9, the captains even of larger vessels objecting to crews of more than I I on account of the difficulty of controlling the men. The number is usually odd on account of the distribution of duties as hereafter explained. As a rule the best men get together, as the proceeds of the trip go into a common fund from which each man receives his share according to his duties, and the presence of an unskilled or lazy man in the crew lessens the catch of the vessel and consequently reduces the profits of his fellows.

When a vessel reaches the sponging grounds, if the weather be favorable and the water sufficiently clear, a bar is located by means of the lead or by 
"sighting" with the water glass, and the crew is sent out in the dingeys, two men in each, while the odd man, usually the cook, handles the vessel under shortened sail and picks up the boats at noon and night, or when signal is made by hoisting an oar blade up.

The men in a boat are called, respectively, the sculler and the hooker, the duty of the former being to propel the boat in obedience to the signals of the latter and to assist in handling the hooks when necessary. A proficient sculler has. great command of the boat, stopping it almost on the instant, backing, going ahead, or making it spin as if on a pivot, as the exigencies of the work require. He will keep at work with easy grace all day long, and much of the success of the boat depends upon his skill and willingness. Upon the hooker devolres the work of finding and catching the sponges. His station is in the waist of the dingey, where he kneels, leaning over the side, watching the bottom through the water glass, the hook, with its pole, resting conveniently at hand across the gunwales, where it may be seized upon the instant. The position is a trying one physically, especially when the sea is choppy, and when the waves grow rough the work is impossible. The sponge glass, or bucket with its glass bottom below the surface of the water, operates by dispelling reflections, and to heighten its efficiency the hooker usually wears a large "conch" straw hat, which cuts off a large part of the direct light when his head is thrust well into the mouth of the bucket. By this means the bottom may be seen more or less plainly in clear water to depths of 50 feet.

When a sponge is sighted the sculler, at a word or signal, maneuvers the boat into position, the hooker seizes his hook, rests the pole on his shoulder as a fulcrum and with his right hand lowers it and inserts the tines into the base of the sponge, more or less plainly seen through the water glass held in position with the left hand. In pulling or tearing the sponges from their attachment considerable care and skill is required to prevent mutilation, which, of course, impairs their value in the markets. They sometimes adhere so tightly that it requires the united efforts of both men to loosen them, and in most cases more or less of the base of the sponge is left behind to grow anew under favorable conditions into a perfect specimen. From this cause, on bars which have been long worked, there are found many sponges of considerable diameter, but so low and flat that there is no room for the insertion of the hooks, and the hookers, much to their disgust, sometimes waste considerable time in futile efforts to detach them.

In deep water poles 50 feet long are sometimes employed, and as they bow and catch in the water if placed athwart the gunwales they are carried fore and aft, the hook over the bow and the other end trailing astern. In using these long, heavy poles the sculler always assists the hooker, placing the pole on the latter's shoulder and helping to handle it both in lowering and in 
bringing it up. Even with this assistance the strain on the hooker is great, and in working in depths of 40 feet or more cases of hernia and similar injury are not infrequent even among strong men. The currents are often strong even when the sea appears calmest, and the slender, flexible poles bend and sway so that the greatest skill and strength are required to direct and insert the hooks. Should the current carry the hooks away from the sponge it is often impossible to force them back, and they have to be brought to the surface for a fresh effort.

Cloudy water brought from the swamps by the streams on adjacent shores, and milky water due to the stirring up of the sand and calcareous marls of the bottom, are the greatest impediments to this method of sponging, and the skill and experience of the hooker are largely exercised in seeing and recognizing the more valuable species under these adverse conditions. The tyro after very little practice can hook sponges in clear shallow water, but in depths of $\mathrm{I} 5$ feet when the water was somewhat roily I have seen one man catch eight times as many as another on the same bar, owing to his superior eyesight, the two men not differing greatly in the length of their experience as spongers.

In deep water-that is, in depths over 38 or 40 feet-probably not more than one-third of the hookers have sufficient strength, keenness of sight, and skill with the pole to work successfully. In consequence of this and the fact that only when the water is exceptionally clear can the sponges be seen at all in the greater depths, most of the hooking is carried on in less than 6 fathoms, and the inshore grounds have been the first, therefore, to become depleted. As a general rule the sheepswool sponge is now more abundant outside than inside the 6-fathom curve, and it is practically commercially extinct in the waters close to shore where it formerly abounded. Experienced captains, therefore, are in the habit of running offshore from time to time to "take a sight;" that is, to look for bottom with their water glasses, well knowing that if the water be clear and other conditions favorable, they can probably take more sponges in a day than they could in a week on the overworked inshore grounds. The spongers state that while the surface water may be clear the lower stratum is often turbid from the bottom materials stirred up by the swinging motion generally observed in the deeper waters of the Bay grounds.

If all the conditions be favorable, which is rare, the harvest is rich for those who can stand the arduous deep-water work. In the summer of 1903 an unusual condition prevailed in the deep water off the Rock Island region, where the water was clear and the weather favorable for a continuous period of many weeks. This gave the hookers access to bars in depths as great as 45 to 48 feet, which had rarely, if ever, been worked, and the result was a heavy catch of large, fine, perfect sponges of the best quality, which brought a good price in the markets. There has been no recurrence of this good fortune. 
As is elsewhere described, sponges are not distributed uniformly over the bottom, but are found only on the scattered bars or rocky outcrops and coral growths. Sometimes a score or more will be found in an area of a few square feet, and again the same number may not grow on an acre of bottom apparently equally favorable for their attachment. Knowing this, the sponging boats will draw together when one is observed to be making a catch and it is not unusual to see dingeys so close to one another that the hookers can hardly wield their poles without collision.

In recent years, where the sponges are much scattered, or the bars small and irregularly distributed, the methods of hooking just described have been somewhat modified to meet the conditions. Instead of the sculling of the dingeys, these are towed by the vessel under shortened sail, sometimes as many as four, two astern and one on each side, from booms rigged well out forward. The hookers crouch in the sterns of the dingeys, scanning the bottom through their glasses, and when a sponge is seen a small buoy with a cord and anchor weight is dropped to mark the spot, the painter is cast off from the vessel, and the sponge is taken in the manner already described. Much larger areas can be systematically covered by this means than by sculling, and regions may be fished with some profit where the sponges have become too few and scattered for the usual methods to yield results.

In the Key grounds the vessels usually anchor at night close to the sponging grounds, and in fair weather some of the larger vessels do the same on the Bay grounds; but the greater number run inshore at night and out in the morning, thus losing much valuable time, especially when the morning winds are light and the conditions are best for work.

The crews are paid on shares, the distribution of the proceeds of a trip being usually as follows: The "vessel" furnishes boats, apparatus, and food, and in return receives one-half of the product of the trip. The other half is distributed so that the hookers get one and one-fourth share and the captain, scullers, and cook one share each. The captain in addition draws so per cent of the vessel's portion and each member of the crew is usually assessed a small sum for the payment of the watchman at the crawls.

The sponging industry of the United States was virtually introduced from the Bahamas, and so far as the spongers themselves are concerned, the fishery remained largely in the hands of the natives of those islands until the introduction of diving. In 1900 , according to Cobb, of the 2,1 I 3 persons engaged in sponging, 1,268 , or 60 per cent, were born in the British provinces, and of these I, or 3 (8o per cent) were negroes. Of the 839 American-born spongers, 343 (4I per cent) were colored. Taken as a whole, of the persons engaged in hooking, about 65 per cent were negroes. Until rgo6 neither the numbers 
nor the proportions above stated underwent material change, but at the present time (I g09) the number of persons engaged in hooking is considerably less on account of competition of the divers, though the proportional national and racial representation appears to be about the same. As a class, these men are industrious workers when actually on the grounds, but after their weekly trips to the crawls it is often difficult to get them promptly aboard the vessels again. The system of making advances against their shares of the catch also operated against their efficiency, as some crews, when a period of "bad luck" made it apparent that at best their earnings would hardly more than suffice to pay their indebtedness, would lose all interest in the work and spend their time largely in idleness or the most desultory labor. Some crews also frequently exchanged considerable parts of their stores for intoxicants brought by Cuban fishing smacks operating off the coast, either drinking the proceeds of the bargain or smuggling it ashore for consumption or sale. This practice has latterly been largely broken up by the customs officers, who have at various times seized vessels, boats, and persons engaged in it.

A very recent development in the hook fishery and one which promises to become important has been brought about by the legislation prohibiting diving during the summer. Certain Greek boats, in order not to be idle at that season, provided themselves with dingeys and hooks during the summer of I go8. They were so successful that several continued in the fishery during the following winter and others are preparing to follow their example. Difficulties with the divers and the expense of maintaining the diving boats appear to be operating to drive other vessel owners into the business, and as the Greeks have shown themselves to be superior to the Bahama and Florida hookers, it would not be surprising if the former eventually practically monopolized all methods of sponging on the Florida coast.

In January, I909, it was possible to institute an interesting comparison between the Greek and "conch" hookers. The former were working in deeper water and were securing a better and more valuable grade of sponges, superior to the catch of their rivals in size, quality, appearance, and curing, factors which very materially increased the earnings of the vessel and crew. This is indicated by the following records of the catch of two vessels which marketed their cargoes on the same day. The schooner Fillmore, manned by io Greeks, out 60 days and fishing in a depth of 35 to 40 feet, marketed 293 bunches of wool sponges for $\$ \mathrm{I}, 88 \mathrm{o}$ and 292 bunches of yellow for $\$ 300$, a total of 585 bunches, selling for $\$ 2,18$ o. Another schooner, under one of the best masters and manned by $\mathrm{I}_{3}$ of the most skilled negro hookers, sponging for 42 days in depths of less than 3 ofeet, marketed 400 bunches of wool sponges for $\$ 889$ and 700 bunches of yellow for $\$ 29$ I, a total of I, I 00 bunches, selling for $\$ I, I 80$. This was a yield of $\$ 2.16$ per 
man-day, while the Fillmore averaged $\$ 3.63$ per man-day, almost 50 per cent more. The Greeks not only worked in deeper water, but by curing their catch on the boat instead of running in to the crawls at the end of each week they lost less time.

\section{DIVING.}

Prior to I905 the methods already described were the only ones employed in the Florida sponge fishery, although Messrs. E. J. Arapian, of Key West, and John K. Cheyney, of Tarpon Springs, had each experimented with diving apparatus without material results. In the spring of the year mentioned, John Cocoris, a Greek, who had been employed in a sponge house at Tarpon Springs, became convinced that the methods employed in the Mediterranean could be successfully employed on the Bay grounds, and with the financial assistance of Mr. Cheyney he began to get together at Tarpon Springs men and material for the experiment. He secured from New York a number of his countrymen who had had experience in the sponge fisheries of the Mediterranean, remodeled a small sloop to suit the purpose of a machine boat, and in April of that year made his first trip and took a large quantity. of fine sponges.

The success attending this venture produced considerable excitement among those engaged in the industry. Those interested in vessels engaged in hooking soon recognized a serious competitor in their business and raised various objections to the use of the scaphander, some of which were well founded and others baseless. In many instances the real objection was not so much the actual or alleged injurious effects upon the beds, but a belief that the divers would lower the price of sponges by vastly increasing the supply, and that, moreover, they could work with profit under market and weather conditions which would make hooking commercially impossible.

During the following winter the opposition crystallized and certain bills were introduced in Congress aiming to prohibit or curtail the use of the scaphander. The conflicting interests appeared before the Committee on Merchant Marine and Fisheries of the House of Representatives and eventually there were passed two bills partaking of the nature of a compromise. On the other hand, sponge dealers, buyers, and some vessel owners, together with a number of persons not previously connected with the industry, saw apparent opportunity for profitable investment, and during the following summer and winter great activity prevailed at Tarpon Springs, and to a minor extent at Key West, in getting together diving outfits. Diving boats were built in New York, New Orleans, and other distant places, some were even brought from Greece, and small schooners were in much demand for deposit or living boats. By May, I906, a little over a year after the first successful experiment, there were 50 diving boats at work and 55 more awaiting crews, which could not be supplied despite a great influx of Greek 
divers and boatmen. In the beginning the crews were paid wages, which under the competition for competent skilled men that developed, rose rapidly until the divers were receiving as high as $\$ 300$ per month. The old system of advances or bounties, which had been the bane of the vessel owners during the preeminence of the hookers, was introduced on the diving vessels, and the owners competed against one another for the best men and even for those of little experience and ability.

These facts were soon noised abroad among the Greeks and there was a heavy influx from New York and a considerable immigration from Greece, until within a year there was a Greek colony of not less than 700 to 800 located at Tarpon Springs and more were coming on every train. A few Americans also engaged in diving, but as a rule they were less successful than the experienced men from the Mediterranean and they gradually dropped out of the business.

Cocoris's experiment was made at a particularly favorable time. The great crop of 1903 , made under unusual conditions on practically virgin deepwater grounds, had been consumed, and the comparatively poor crops gathered by the hookers in the succeeding year had left the market largely depleted of high-grade goods. To allay to some extent the animosity of the users of the established method, the first diving boats went well offshore in depths of 7 to Io fathoms, where they found sponges of large size and cxcellent quality for which the buyers were ready to give high prices. Each dealer was anxious to secure his full share of the product, and being uncertain as to the possible yield and the period during which it would be maintained, prices continued high throughout the year, reaching their culmination in February, 1906, when one particularly excellent cargo sold for \$I per bunch, the highest price ever paid, the usual price for divers' sponges at that time being $\$ 8$ to $\$$ Io per bunch.

Between January I and February I5, I906, a season when under the old methods very little was marketed, over $\$ 60,000$ was produced by diving. By the middle of April about 40 outfits were at work and this number had increased to 50 by the middle of May, at which time the yield from January I had been no less than $\$ 250,000$ and about $\$ 20,000$ worth was coming in weekly. The boats properly manned were averaging about 500 to 600 bunches per month and one got 500 bunches in five days without moving much over a mile. Under this heavy supply the price broke sharply and sponges which would have brought $\$ 8$ to $\$ 10$ per butich in February were selling for $\$ 2.75$ to $\$ 3$ in May.

Under these conditions the exorbitant wages of the earlier trips became prohibitive and the divers were placed on shares, their pay then being more dependent upon their own skill and industry. In some cases the other members of the crew were on shares, but about May I, I906, when wages were paid, the managers or overseers, stem oarsmen, and life-line men, received $\$ 75$ to $\$ 8$ o per month, and the pumpers and bow oarsmen from $\$ 50$ to $\$ 60$. Under the 
discouragement of low prices for sponges and the demoralized condition of the labor problem, some of the diving outfits were withdrawn from service and tied up, while others recently built or acquired never went into commission. Other owners, unable to deal efficiently with crews speaking an alien tongue, gave up the attempt to operate directly and chartered their boats and outfits to Greeks, who have thus gradually assumed a practical monopoly of the diving operations, though under the navigation laws it is necessary for them to employ citizens of the United States as nominal masters of the living or deposit boats.

There was also about this time a change in the quality of the product. Previously there had been but few small sponges and the large ones were perfect forms, but in May, I9o6, there were many small ones in the cargoes and many of the large ones were old, ragged, and inferior, about 30 per cent of the whole being packed as cuts and seconds. One typical cargo packed as follows:

\begin{tabular}{l} 
Sizes, $a$ \\
\hline
\end{tabular}

a The sizes are based on the number of sponges or pieces per pound.

The depreciation in quality was apparently due, in some degree at least, to a change in the locality of the fishery. The Greeks, feeling that they were, in a measure, interlopers, at first treated the prejudices of the hookers with considerable respect and carried on their work far offshore, on virgin or little worked beds, where the run of sponges was large and the quality good. It was stated that some cargoes came from a depth of 14 fathoms and there were reports, never properly authenticated, of diving in still greater depths, but there is no doubt that the major portion of the catch came from depths of between 40 and 60 feet. As it became more apparent that the divers were not to be seriously molested, despite the loud threats of some of the hookers, they became more confident and encroached more and more on the beds in shoaler water, where, of course, they took the same class of sponges brought in by the hookers. The arduousness of diving and its physical perils increase with the depth of water, and the divers will not work in deep water if they can get sponges in the shoaler. 
The first diving or machine boats used in Florida were small sponging sloops from which the cabins were removed and which were otherwise remodeled to suit the requirements. The pump was installed in the hold, from which the hatch was removed, the sides were built up and pins or crutches, two on each side at a considerable height above the deck, were provided for the sweeps. A shorter mast was introduced and rigged with a spritsail.

It was soon found that these boats were heavy and clumsy for the work, and boats of the Greek type (pl. xxIx) were speedily introduced and are now almost universally employed. They are "double-enders" with high bows and sterns and considerable shear, making them good, dry sea boats in any weather, either under way or at anchor, and they are spritsail rigged. More recently gasoline engines have been placed on many of the boats, the propellers being guarded by cages to prevent fouling of the hose or life line, an accident which might readily prove fatal to the diver at work. The machine boats are also provided with two pairs of stout crutches, to which the sweeps are slung by rope loops or grommets, and on each side amidships is a rail about I 8 inches high, with a sailcloth curtain or screen stretching to the gunwhales. When not in use the oars or sweeps rest fore and aft on the crutches. On the starboard side forward is a heavy ladder, hinged so that it can be swung outboard or stowed inboard as required, and of sufficient length to extend 2 to $2 / 2$ feet below the surface of the water. This is an essential feature of the machine boat, as without it the diver in his heavy cumbersome armor could be brought aboard only with extreme difficulty. The Greek boats have each a circular hatch forward, in which stands the man using the water glass. The machine boats of the Greek type are about 32 feet long and about I f feet beam on deck, and, fully equipped with a good pump and gasoline engine for propulsion, cost about $\$ 2,000$.

The pump is of the usual type employed in diving operations, is placed amidships in the boat and when not in use is covered by a hatch to protect it from the weather. The diving dress consists of a helmet, breastplate, shoes, and weights. The suits, which are made of several sizes to suit the physical proportions of the divers, are of double waterproof cotton cloth with rubber between and completely cover the body with the exception of the hands, a close-fitting rubber cuff being provided at the wrists, and a heavy rubber yoke or collar extending across the breast, back, and shoulders. The helmet is of tinned copper with three heavy glass windows at the front and sides and one obliquely above in front. At its back are two valves, one with a connection for the hose and the other for the discharge of vitiated air. In some helmets the latter valve is automatic, but few of the Greek divers will use this, preferring those in which the escape of air from the helmet is regulated by the diver, the valve being held in place by a spring and released by pressing against it with the 
back of the head. The fresh air is conducted in flat tubes from the intake toward the front side of the helmet, serving the double purpose of supplying unvitiated air for respiration and preventing condensation on the window. The hose is of the best quality, covered with a canvas jacket to protect it from abrasion and with tight screw couplings between the sections, the weight of the unions being compensated for in the water by cork floats. The rest of the hose is of itself sufficiently buoyant when full of air.

In preparing to descend, the diver dresses in heavy woolen underclothing and stockings, and thoroughly soaps his hands and wrists to permit pulling on of the rubber cuffs and to secure closer contact at the wrists. With assistance he then crawls into his suit; the breastplate, covering the upper part of the breast, back, and shoulders, is inserted inside of the rubber yoke, which is provided with eyes fitting over corresponding screw lugs on the breastplate and the two are clamped to a water-tight joint with thumb screws and brass straps. Stout weighted leather shoes, brass soled and tipped, are then securely strapped on the feet. In the meantime the interior of the helmet has been washed and the air supply tested by placing water in the helmet to determine whether the air bubbles freely through the intake valve when the pump is operated. The pump is then started slowly and the helmet secured to the breastplate by an interrupted screw, the joint being made water-tight by means of a rubber gasket. The helmet is then lashed to the breastplate, the front and back weights of lead are lashed on, the hose brought under the left arm and lashed to the waist and the life line is fastened tightly around the body under the arms.

The diver is then ready to descend, and with his burden of about 200 pounds is assisted to the side, where he either jumps, or rather falls overboard, or else climbs down the ladder, the pump being run more rapidly as needed to supply the air pressure commensurate with the depth in which the diver is working.

The crew of a machine boat with their stations when at work is as follows: Two divers, who alternate on account of the arduousness of their duties, one resting while the other is at work; these men are always particularly abstemious as to food and drink, no alcohol being used and the daily meals consisting of a cup of coffee in the morning and a hearty dinner at night when the day's work is over. Three oarsmen; the bow oars are pulled each by one man sitting down, but the stern oarsman stands facing forward and pushes two sweeps, which are balanced by heavy weights near the handles so as to reduce the fatigue of rowing. Two pump men and one relief who manages the hose when not pumping. One life-line man, whose important duty it is to see that the life line is kept clear and that the signals of the diver are promptly regarded; experienced and careful men are required for this station, as the 


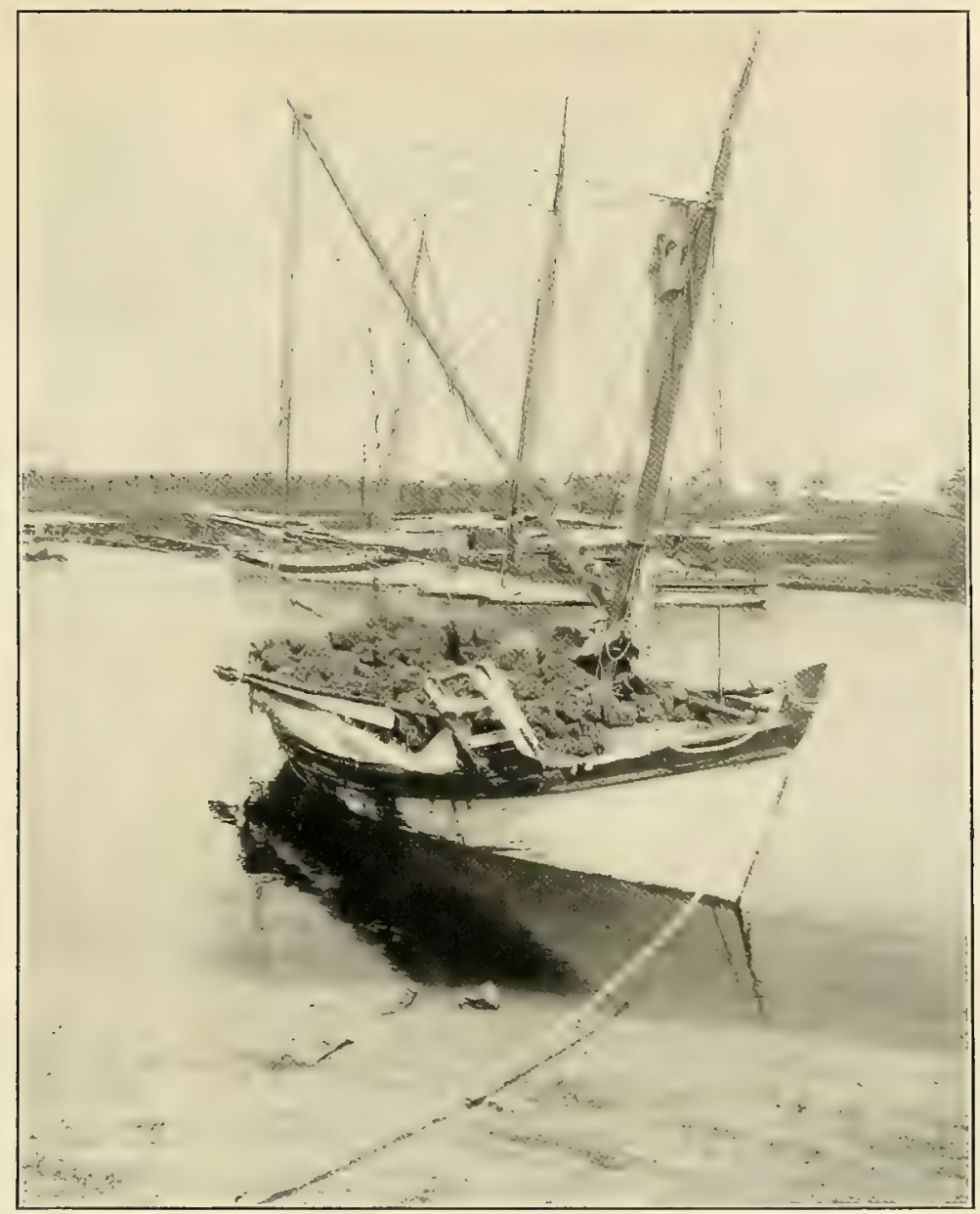

FIIs. I.-Diving boat, with cured catch. Shows diver's ladder triced up.

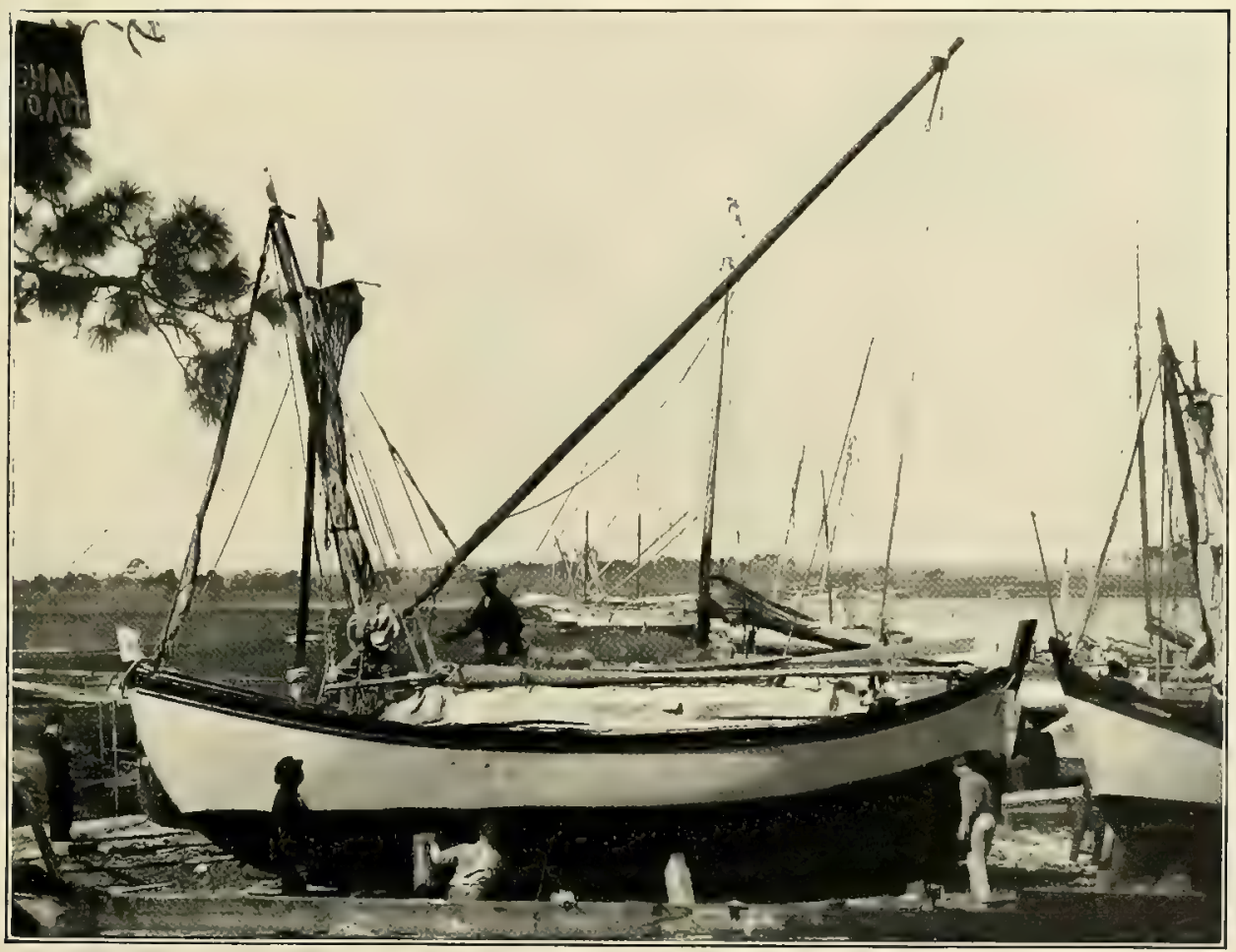



efficiency of the diver's work and not infrequently his life depend upon intelligent communication between him and the boat, while delays and misinterpretation of signals are always annoying and in case of the emergencies likely to arise in this class of work are exceedingly dangerous. One hoseman, the relief from the pump, who pays out or takes in hose as the diver moves away from or approaches the boat; a surplus of hose trailing out in strong currents impedes the diver in his progress over the bottom, and should the hose become fouled, pinched, or kinked the supply of air may be cut off with possibly serious results. When moving from place to place the hose tender relieves the stern oarsman, and the bow oarsmen and pump men alternate at their respective duties, thus obtaining some rest. On boats provided with gasoline engines there is sometimes in addition a man to run the engine.

At the present time ${ }^{a}$ the rates of pay are based on shares as follows: The operator furnishes the boats, outfits, and provisions and receives one-half of the gross proceeds of the trip, the remainder being divided into shares, of which the divers receive $2 \frac{1}{2}$ or 3 , the life-line tender and stern oarsman $I \frac{\pi}{2}$, and the others of the crew 1 each.

The deposit or living boats are usually schooners, such as are commonly employed in the hook fishery, most of them between ro and 20 tons register. They furnish the living quarters for the crew and a place of deposit for the sponges, most of which at present are cured aboard, as is done in the Mediterranean. They carry in addition to the diving crews a master, one deck hand, and a cook, the former being a citizen of the United States, as required by the navigation laws. To each deposit boat, according to its size, there are attached one or two machine boats with their crews. During the first year of the fishery one schooner was fitted for three diving crews, but it has never gone into commission, on account of the depression of the price of sponges and the lessened profit of operation. Most of the boats carry but one diving crew.

The method of carrying on the fishery is as follows: When the vessel arrives in approximately the region where she wishes to work, the bars are located by sounding with the lead or by towing a small grapnei lashed in such manner as to trip when it fouls. When a bed of suitable size is found, it is marked with a buoy and the machine boats are sent away. Since the latter have been equipped with engines, they themselves frequently search for the bars. The diver then dresses as before described and descends, taking with him a netting bag about 2 feet deep and 18 inches or more in diameter, with a hinged hoop at the top closing like the frame of an old-fashioned carpet bag. The boat, propelled either by the oars or by means of the engine, follows him in his progress over the bottom, which is marked by a stream of fine bubbles escaping from 
the wristbands of the suit and by sudden eruptions of large ones discharged from the relief valve, which he opens from time to time by throwing his head back against the helmet.

He regulates the air supply with two purposes in view-respiration and a proper degree of buoyancy in his suit. If all is working properly the suit is always more or less inflated, and in spite of the great weight of the man and his armor, $35^{\circ}$ to 400 pounds as weighed in air, he treads the bottom with a pressure of but a few pounds. Should insufficient air be liberated the suit becomes still more inflated and its buoyancy will carry him to the surface, a method frequently employed in making ascent from moderate depths, but liable to produce serious hygienic consequences if practiced under greater pressures. If the pump be working too rapidly or too slowly he gives the proper signal by jerking on the life line, and the supply of air is modified accordingly.

In moving over the bottom the divers do not walk as do persons on land, a thing impossible owing to their levity and the resistance of the water. Their movements are rather a series of headlong springs or dives upward and forward with the body strongly inclined.

As the diver finds the sponges, which in the region in which the work is carried on are of but four kinds-sheepswool, yellow, wire, and grass- he tears them loose and places them in the bag, which when full he signals to have pulled up on the life line and an empty one sent down. When he wishes to come up, he gives the signal and walks toward the side of the boat, the direction of which he can determine by the trend of the life line, or else he buoys himself to the surface and is hauled in hand over hand, rotating and rolling like some monstrous form of the deep, with the air whistling and gasping at intervals from the relief valve. Reaching the ladder, he laboriously ascends with the assistance of one or two members of the crew, his helmet is taken off, and, unburdened of his chest and back weights, he comes aboard to be relieved by his diving mate. )

The length of time that a diver can safely stay submerged depends upon his physical strength and endurance, but especially upon the depths in which he works. On the Florida coast, where sponging is generally carried on in less than 60 feet, the usual shift is about two hours down and two resting, but fairly good divers can stand longer shifts.

The maximum depth at which divers can work has been a matter of dispute among the spongers, but there is no doubt that they can go much deeper than they have ever yet gone on the Florida coast (about i io feet), though at the greater depths their efficiency decreases and they become subject to serious maladies, which will be discussed later. The laws of Greece, for humanitarian reasons, prohibit diving at greater depths than 38 meters ( 125 feet), but it is said that the Mediterranean sponge divers sometimes work in 40 fathoms (240 
feet). Siebe, a recognized authority, states that I 50 feet is the maximum limit for safe diving by physically sound men, and that the greatest diving feat known is a stay of forty-two minutes in a depth of zor feet.

The proceeds of a sponge diver's work depend upon a number of conditions - his own skill and industry, the condition of the water, and the abundance, size, and distribution of the sponges on the bottom. During the spring and summer of 1906, when the boats were working in from 40 to 60 feet of water, with good average weather conditions and sponges relatively abundant, two divers working alternately were taking on an average about 20 bunches a day, or, making allowance for time lost from various reasons, between 25 and 30 bunches per working day. One of the most successful trips averaged 5o bunches per day for each diver, or about 500 bunches in five days for the boat. For single days this average has been considerably exceeded.

During the season for diving, which under act of Congress began October I, 1907, and closed April 30, 1908, the conditions were far from favorable, the weather especially during the winter and spring being unusually turbulent and the water almost constantly turbid. In consequence of this the divers were working closer to shore, in water of much less depth than the minimum prescribed by law, and in April I saw two boats operating even within state jurisdiction. The sponges brought in were ragged and inferior in size and quality, and many of them were, moreover, poorly cleaned. The proportion of small sponges was large, the limit prescribed by law being almost wholly disregarded, as was also the case during the season preceding. I saw large quantities of small sponges in some of the packing houses, and it is a matter of common notoriety in Tarpon Springs that many small sponges packed in bags are shipped by the Greek spongers without ever being exposed to sale at the Sponge Exchange.

Owing to the unfavorable weather the product per outfit during the season from October I, I907, to May I, I908, was much below that stated above, averaging about 300 bunches per boat per month. The total yield was $\$ 392,399$, as compared with $\$ 638,766$ the year before, but this was due in part to the restriction of the diving season to seven months during the period least favorable for work. The character of the catch during the season is indicated by the fact that 50 per cent of the sponges were larger than twelves, about I 2 per cent were twelves or smaller, and 38 per cent were packed as cuts and seconds. The yield was inferior in quality to that of the first year of the fishery, but was about the same as in 1906, excepting that the proportion of cuts and seconds was higher.

During the winter of $1908-9$ the yield of sponges on days when the weather was favorable was from to to i 5 bunches per diving boat. The following actual 
returns will illustrate the average catches during the months of December and the early part of January:

Diving boat Amphitrite, out two months:

I72 bunches sheepswool, selling for $\$ 1,292,05$

60 butrches small sheepswool, selling for

253 bunches yellow, selling for

84 bunches grass, selling for

569 bunches all kinds, selling for

Diving boat Harikila, out two months:

I6o bunches sheepswool, selling for

$\$ 1,353.00$

59 bunches small sheepswool, selling for

205 bunches yellow, selling for $\ldots \ldots$

70 bunches small yellow, selling for _..... . .

94 bunches grass, selling for _....... 550

588 bunches all kinds, selling for

Schooner Edna Louise, with two diving boats, out seventeen days:

250 bunches sheepswool, selling for

$\$ x, 398.00$

75 bunches small sheepswool, selling for

I01. 00

444 bunches yellow, bid refused

248. 00

I 5 bunches wire, bid refused

83.00

884 bunches all kinds, bid

I, 830.00

These figures give an average per boat day of about I 3 bunches of sponges of all kinds, selling for $\$ 35$.

As compared with hooking, diving requires a more expensive equipment. The smaller vessels of the old fleet are not suitable for living boats, for the crews are necessarily large and require the same accommodations needed for an equal number of hookers, especially as the sponges are now cured on the vessels. In addition, the diving or machine boat, with its pumps, suits, and gear, is much more costly than the sponge hooks, glasses, and five or six dingeys which constitute the secondary equipment of the hooker. The expense of operation and maintenance is also greater, and to pay expenses the yield per man must be considerably larger.

To compensate for this, diving has several advantages: It can be carried on in rougher and more turbid water and at greater depths, and, moreover, the diver can get sponges inaccessible to the hooker working on the same beds. In practice, too, the diving crews can be kept more persistently at their work, and the Greeks are less prone to lose time running inshore at night unless under stress of weather. When diving was first introduced on the Florida coast it was claimed that but rarely would the sea be so turbulent as to stop operations. Experience, especially that of the last season, has shown that this fishery also is more or less at the mercy of the weather and that while it can be prosecuted 
when hooking would be absolutely impossible the frequent gales and strong northers which sweep the Gulf of Mexico in winter and early spring are factors that have to be reckoned. with, and the proportion of days of enforced idleness is considerable.

The turbidity of the water is also a factor, and while it is rarely absolutely prohibitive, as with the hookers, it at times more or less seriously interferes with the efficiency of operations. When the water is clear and the light good, the diver can see plainly at a distance of some yards, but on cloudy days in turbid water sponges more than a few feet away will escape notice, especially if the bottom be covered with gorgonians and similar growths. It will be readily understood that under such conditions the efficiency of the diver is much reduced, so that he must necessarily miss many sponges that would be readily found under more favorable circumstances, and that while moderately clear water is not essential, as in the earlier methods of sponging, its relative prevalence is reflected in the balance sheet at the end of a trip.

The ability of the diver to penetrate to a depth beyond that accessible to the hooker is of value only if sponges extend into the deeper water. That this is the case to some extent has already been demonstrated, but there is as yet no indication that the beds extend to depths equal to those attained in the Mediterranean. The advantage in the efficiency of the two methods at depths of 40 feet or more, where the hooker is approaching his limit, is vastly in favor of the diver, who can work there in average weather, while the hooker can operate only under very rare combinations of favorable conditions.

Finally, the diver is able to gather sponges which, while within the limits of the hooks, are so situated as to be invisible or inaccessible from above. As has been stated elsewhere, the bottom on the beds is rough and irregular, and many sponges grow in crevices, on overhanging ledges, or hidden by masses of coral, and can not be gathered by the hooker. The diver walking over the bottoni can find and secure almost everything, stripping the bottom almost bare if he wishes.

\section{- KILLING AND CURING.}

When a sponge is brought to the surface a certain anount of air immediately enters its pores and replaces the water in some of the canals and chambers. In this condition it will float, and the spongers, taking this as a sign of death, believe that the sponge is killed immediately upon exposure. If the floating sponge be left to itself, however, most of the entrapped air is soon expelled by the pressure of the water and it will then sink and become a "roller." The air can also be expelled without injury to the sponge by gently squeezing it under water. The hookers have always killed their catch by prolonged exposure on the decks of the vessels, the sponges being carefully placed "root" down, so as to facilitate the escape of the "gurry," or liquefied organic matter which 
results from decomposition. In hot sunny weather death comes rather quickly and the internal tissues begin to slough in a day or two, but when it is cold and cloudy a week of exposure is sometimes insufficient to kill the tissues throughout, the result often being the retention of more or less hardened matter in the substance of the cured sponge, to the detriment of its value and very difficult to remove by subsequent treatment. The spongers recognize this fact, but being imbued with the idea that the sponge is dead as soon as removed from the water they ascribe it not to retained vitality but to what they call "chilling," a physical change in the fleshy substance of the sponge which causes it to resist decay. During the process of killing some care has to be exercised to prevent the skin from drying and adhering to the skeleton.

Each hooking vessel has located somewhere along shore at a point accessible to the sponge grounds an inclosure called a "crawl" or "kraal," about Io feet square, constructed of stakes driven close together and nailed to horizontal pieces to keep them from spreading. Among the keys the crawls are usually isolated, small, and of a temporary character, but on the Bay grounds they are more substantial and grouped under the care of a common watchman to prevent the depredations liable to occur during the distant absences of the owners. The Bay fleet has groups of crawis near Cedar Keys Light and at Baileys Bluff, Sawyers, and Union Crawl, just north of the mouth of Anclote River, and at various times they have been established at other localities. In these inclosures the dead sponges are placed to macerate, the organic matter undergoing rapid decomposition and liquefaction. This method appears to have originated in the Bahamas, the first sponges produced in Florida being rather poorly cured, principally because they were not thoroughly beaten and squeezed. It is stated that for similar reasons the first product of the Bay grounds was regarded as inferior to the Key sponges and sold at a lower price.

Usually on Friday night the vessels run in to the crawls, and Saturday is spent in "crawling" the dead sponges of the recent catch and cleaning those deposited on the Saturday previous. During the week most of the fleshy matter has macerated and washed out and the remainder is removed by beating the partly submerged sponge with a short heavy stick and by repeated squeezing under water. If particles of skin adhere they are scraped off with a dull knife. The crawls are always located in salt or brackish water, as maceration in fresh water darkens the fiber of the sponge. By means of a long needle the cleaned sponges are then strung on rope yarns 6 feet long, the ends of which are tied together to form wreaths, technically known as "bunches," which are partly dried and stowed in the hold of the vessel pending the end of the trip. The approved method is to string together sponges of approximately the same size, "eye and root"-that is, with the top of one sponge against the bottom of its neighbor-but some captains will have their catch 
strung so as to make the largest possible number of bunches by placing the minimum number of sponges on each, a subterfuge which rarely deceives the watchful buyer, who reduces his bid accordingly.

The diving boats at first followed the same methods, but afterwards to obviate the loss of time involved in making the weekly trips to the crawls and to save the expense of employing watchmen they recurred to the method of cleaning on the vessels, to which they had been accustomed in the Mediterranean. The sponges as taken are placed on deck and thoroughly trod under the bare feet of the crew, so as to hasten death by crushing the soft tissues. They are then hung over the side to macerate, after which they are washed out on deck in tubs of sea water. The results of this method of cleaning were at first regarded as less satisfactory than of that practiced by the hookers. Occasionally more or less solid matter is retained through imperfect killing and maceration, and in addition the water in the tubs is sometimes allowed to become thick and gelatinous with partially dissolved animal matter, which, adhering to the fiber, makes the sponge hard when dry and sticky when moist. When sponges so treated are thrown on the beach, sand and dust adhere to the surface, injuring the color and making pure goods look as if "loaded." When properly performed, however, the results are good. Less sand is picked up by the sponges than when they are rolled about in the crawls, and as the animal matter is more quickly removed there is less injury to the fiber of the sponge than if the maceration be more prolonged. The sponges are also lighter in color and cleaner in appearance, while the soluble animal matter left in the sponge by the washing in tubs is appreciated by the buyers as adding to the weight.

\section{THE SPONGE TRADE}

Buying.-The first sponges produced in Florida were sold to one or two merchants at Key West or exchanged for goods at a fixed price of ro cents a pound, but as the demand increased compatition for the product grew also an the method of selling at auction developed.

At Key West, which held an absolute monopoly of the trade until about I $89 \mathrm{I}$, a wharf is set apart as a sponge market, the buyers each paying for its use a fee proportional to the amount of their purchases. Here the spongers bring their catch and spread them, sorted according to kinds, in piles arranged to show them to best advantage, the sponges being wet to swell them to their largest proportions. At appointed times the buyers assemble, and, proceeding from pile to pile, bid for each separately, basing their offers upon the number of bunches and the size and quality of the sponges. Each buyer writes his bid upon a slip of paper and hands it to the person appointed for the purpose; who when all bids are in reads them off, the highest taking the lot, though the owner may elect not to sell at the price offered. Intending buyers usually examine the 
several cargoes offered before the sale begins, and the bids usually run pretty close, though I have seen a bidder, through some miscalculation and his anxiety to buy, offer 40 per cent more than his nearest competitor.

At Tarpon Springs until recently the sponges were sold at the several crawls at such times as the spongers chose to offer them. As the crawls were several miles from the town and separated from one another by considerable distances, much time was often lost in the disposal of relatively small quantities. To obviate this a sponge exchange has been organized by the buyers, who have bought a suitable site on the river near town and have erected houses and bins suitable for the storage of their purchases. The expenses of construction and operation are borne jointly by the buyers, or the houses which they represent. The actual sales follow the system already described. Tarpon Springs first became a sponge mart on a small scale about $189 \mathrm{I}$, and at the end of ten years it had passed Key West in importance. With the waning of the catch on the Key grounds, and especially with the development of diving, it has now secured a practical monopoly of the business and Key West has become an almost negligible factor.

Packing.-As purchased from the fishermen the sponges are cleaned of animal matter, but they are more or less irregular where they have been torn from the bottom, and they frequently contain shells or fragments of coral and rock. After they are received at the packing house these foreign particles are removed and the irregularities and torn parts clipped off with sheep shears, the "clippers" requiring some skill to reduce the sponge to a regular shape with a minimum of waste, the work being done to best advantage while the sponges are wet. Large specimens, for which there is a limited demand, and especially those which are torn or contain crab holes, are cut into pieces with a sharp knife, the edge of which has been serrated with a file. Nearly all Anclote or Bay grass sponges, which are usually large and cup-shaped or conical, are so treated, as are at times considerable quantities of sheepwool and yellow sponges. There is always more or less loss in cutting up large sponges owing to the waste of trimming off the sharp edges left by the knife. After being trimmed the sponges are sorted according to size and quality, the whole perfect specimens being known as "forms," those with holes and similar imperfections as "seconds," while cut pieces are known as "cuts." The sizes are named from the number of "pieces" required to make a pound, the usual sizes being "ones, twos," "twos to threes," "threes to fours," "fours to sixes," sixes to eights," "eights to tens," "tens to twelves," "twelves to sixteens," and "sixteens to twenties." The "sizing" is usually made by eye, but in some cases, for greater accuracy, the sponges are passed through holes or rings.

The first sponges shipped from Key West were packed in cylindrical bales about 6 or 7 feet long and compressed by hand or treading with the feet, but within 
a few years a dealer versed in the methods of the Bahama fishery introduced the present type of square bales. These vary in size according to the demands of the trade, the standard weights being $15,30,50$, and 60 pounds. But one size, kind, and grade of sponges is placed in a bale, the pieces being packed in layers and rows, due care being exercised that when the head of the bale is opened the contents shall present the best possible appearance. A simple screw press is used for compression of the bale to about 40 per cent of its hand-packed thickness. The bales while still under pressure are sewed up in burlap and corded with jute rope $1 / 4$ or $3 / 8$ inch in diameter. They are then weighed and marked with a card giving the date, the kind and grade, the weight, and the number of pieces. The sponges are packed almost dry, so that the pieces when relieved from pressure remain compressed until moistened. Owing to the hygroscopic character of sponges, the weight of the bales fluctuates in accordance with atmospheric conditions, moisture being absorbed in wet weather and discharged in dry, and dealers and jobbers selling sponges by the bale frequently keep their stocks in damp places for the sake of the gain in weight. When reasonably dry, baled sponges will keep for years without deterioration, but if allowed to become wet, especially with fresh water and in warm weather, they sometimes "heat" and turn yellow or orange in color, with more or less loss of strength of fiber.

During ten years or so preceding the inception of diving, owing to the limited supply of sponges and their high price, there grew up a practice of "loading" by which the weight was increased by the addition of foreign matter of various kinds. In later years this practice became so extravagant that practically all Florida sheepswool sponges were loaded to double their natural weight and in some cases the increase was 50 per cent. The fact of loading was well known in the trade and what was originally a deception became in the end a sort of legitimate fraud which deceived nobody, though the degree to which it should be practiced was a source of constant controversy between the packers and the jobbers. The process was originally fraudulent, but eventually absurd, the same amount of actual sponge being obtainable at about the same price, whether loaded or pure. In fact, a pound of pure sponge could usually be obtained at a slightly lower cost than double the quantity of goods loaded roo per cent, the packer having to reimburse himself for the labor and materials consumed in loading. In addition, the quality of the loaded sponge was injured by reason of the gritty materials employed, which detracted from its usefulness for the finer purposes in the arts.

The methods of loading were supposedly kept more or less secret by the various packers, but, as a matter of fact, they differed only in minor details. The clipped sponges were placed in tanks containing. a "dope" composed of water, glucose, glycerine, dextrin, salt, litharge, sand, and similar materials; the 
whole being thoroughly stirred or tramped under foot to keep the heavier materials in suspension and incorporate them in the texture of the sponge. At first the excess of moisture was squeezed out by hand or with a clothes wringer, but later, when the desire for heavier loading became strong, the sponges were merely drained on a rack and then placed in the sun to dry.

When the supply of sponges was temporarily increased through the introduction of the diving machine and the price fell, loading was almost abandoned and most of the goods were shipped pure. But during 1908 the practice again developed, though the loading did not exceed about 25 per cent. At the beginning of 1909 , with an increase in the price, there was a tendency to increase the percentage. The sand, salt, and glucose which formed the bulk of the old loading have been replaced by barytes, epsom salts, and dextrin, which are less gritty, not so hygroscopic, and more readily worked out. The present desire to increase the loading will probably induce the use of sand, as it is difficult to get the added weight without it.

Bleaching.-The sponges used in the arts are usually in their natural condition so far as color is concerned, but for bath purposes, many persons prefer them bleached.

A fine whitish bleach which does not greatly injure the quality of the sponges may be imparted by repeatedly impregnating them with dense soapsuds and exposing them to the action of sun and air.

A bright yellow color, such as is generally seen in the bath sponges of the shops, may be produced as follows: Soak the sponges for about ten minutes in 5 per cent hydrochloric or sulphuric acid; then thoroughly wash in water and place in 5 per cent potassium permanganate solution until they have assumed a very dark brown, almost black, color; thoroughly wash again in fresh water and place, until almost decolorized, in a ro per cent solution of oxalic acid. After another very thorough washing place them in a ro per cent solution of sodium carbonate (washing soda) until they assume a bright yellow color. A very thorough washing completes the process. The fiber of all chemically bleached sponges is more or less injured by the treatment, and though softer they are inferior to the natural sponges in durability and resiliency and soon become soggy in use.

\section{STATISTICS}

No statistics of the Florida sponge fishery are available for years prior to I880, and no complete canvass, separate from the general fisheries of the state, was made until I 900 . The following tables ${ }^{a}$ exhibit in some detail the extent of the fishery in the years 1903 to 1908 , inclusive, embracing the transition period during which hooking was largely supplanted by diving. 
The difficulties in dealing statistically with this period have been considerable, as persons, and especially vessels, have been engaged, in many cases, part of the year in hooking and part in diving. In each such case, however, effort has been made to accredit the vessel to that method in which its activities predominated during each year.

The tables are interesting as showing not only the changes in the methods of the fishery, but also as exhibiting the shifting of the location of investment incident upon these changes. Until the inauguration of diving the investments at Key West (Monroe County) were paramount, but in 1906 Tarpon Springs (Hillsboro County) passed Key West as a center of investment, as it had done some years previously as the principal sponge market. In I 908 the capital employed in the fishery at Tarpon Springs exceeded that at Key West by about 85 per cent.

In the tables of the product for the years 1903 to I 908 , inclusive, the weight is based upon the number of bunches purchased. In previous years it was determined from the pack, a method highly defective on account of the practice of "loading."

PERsons EMploye in THE Sponge Fishery of Florida IN 1903-igo8, by Counties.

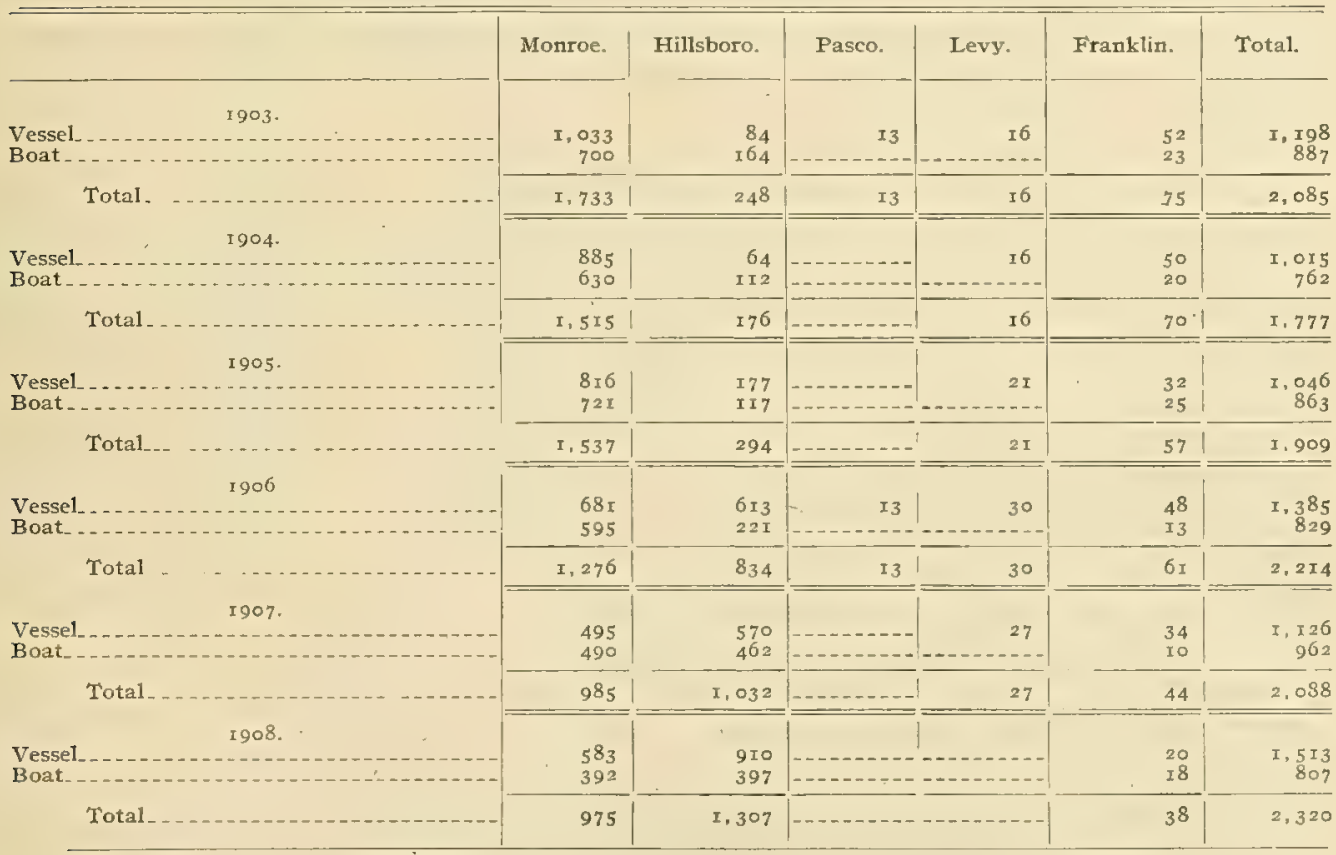




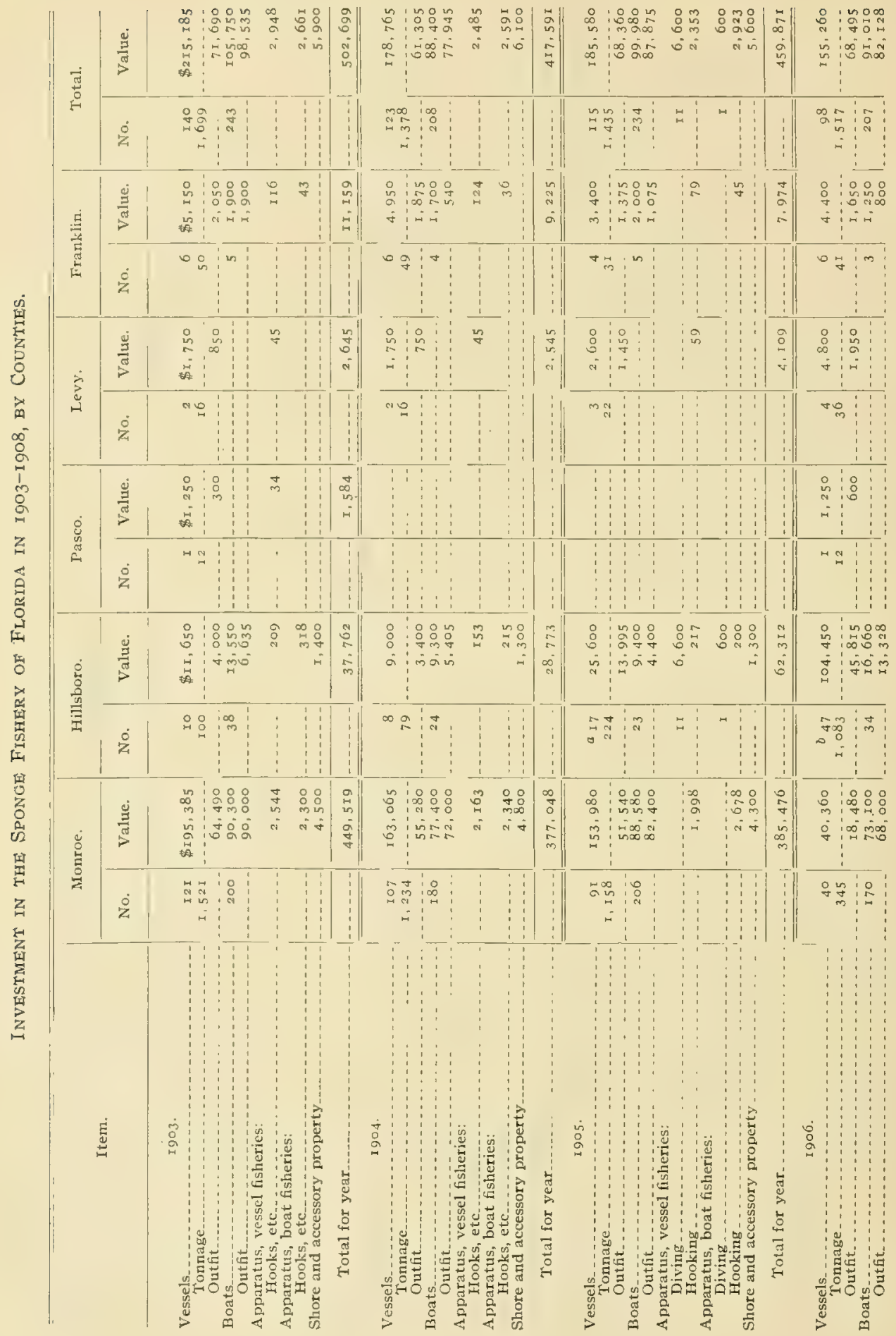


THE COMMERCIAL SPONGES AND THE SPONGE FISHERIES.

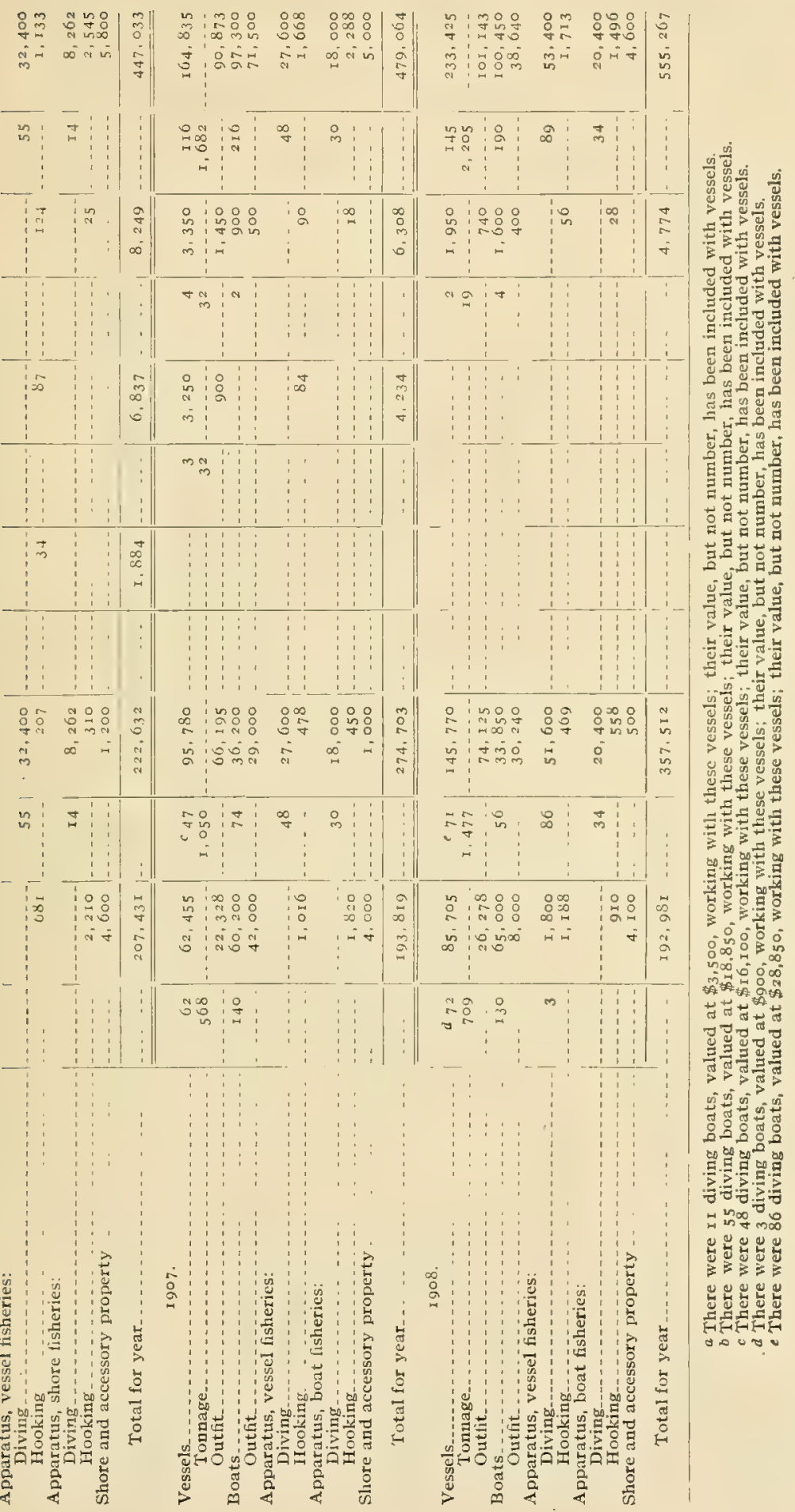




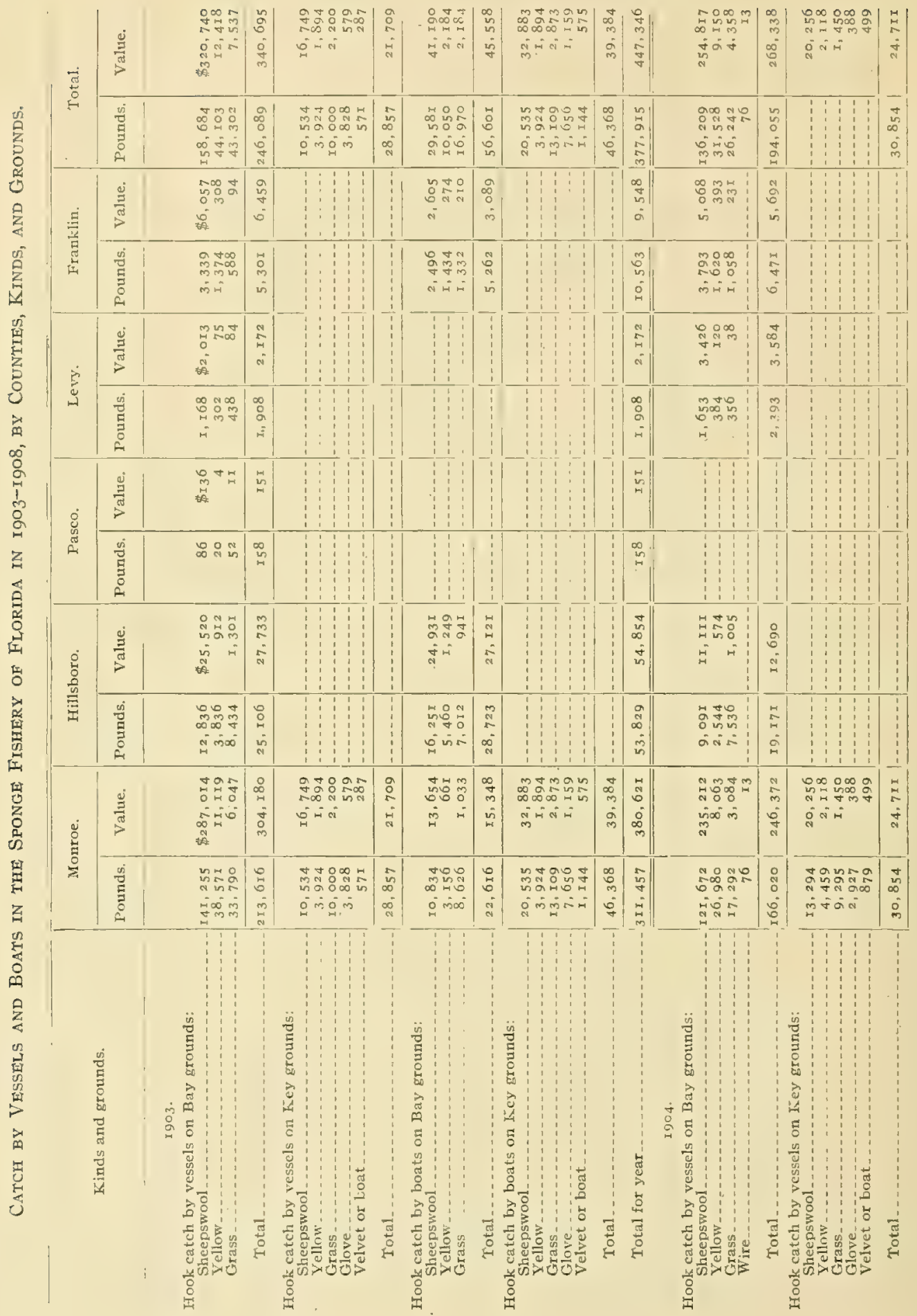


THE COMMERCIAL, SPONGES AND THE SPONGE FISHERIES.

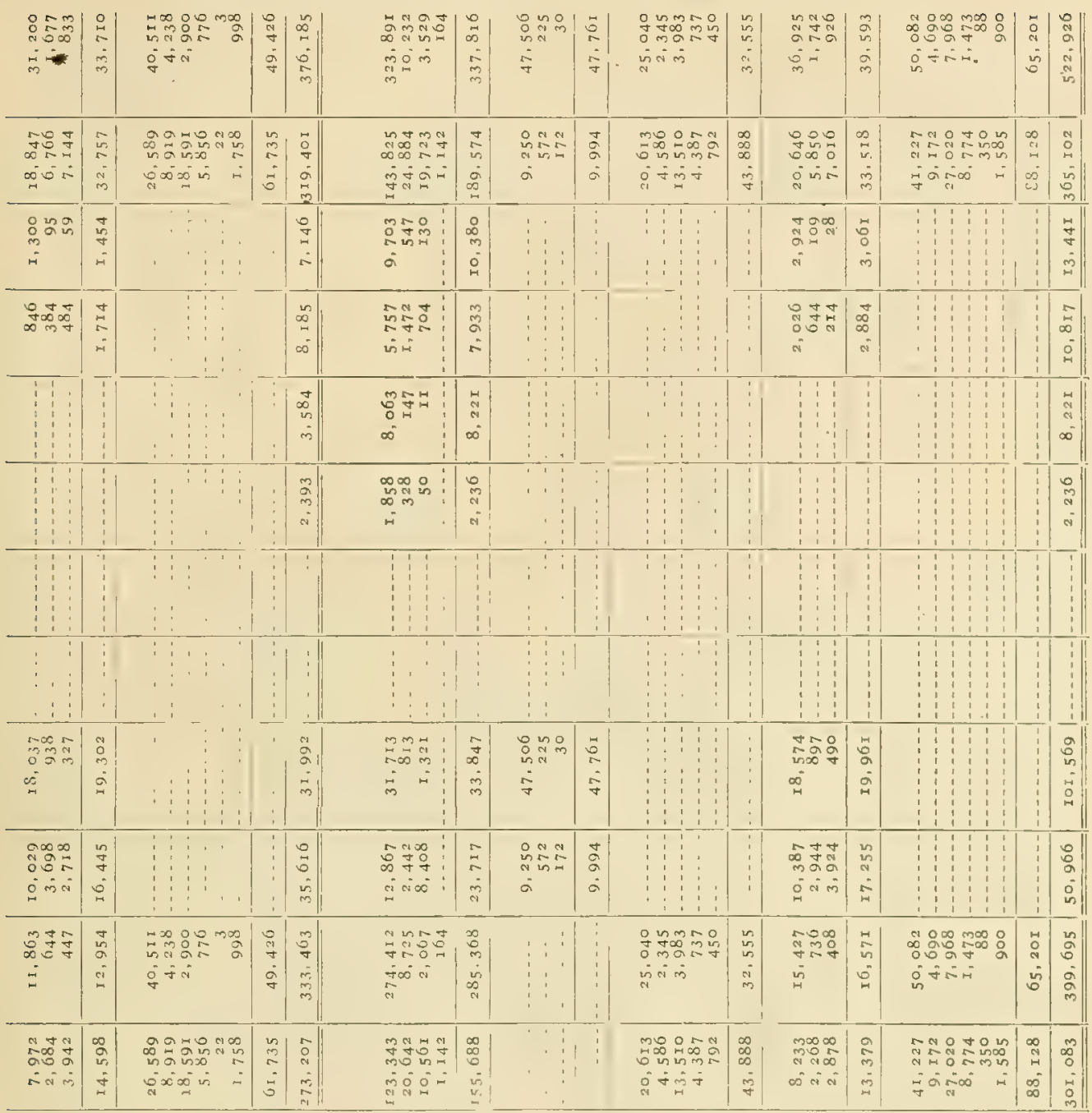

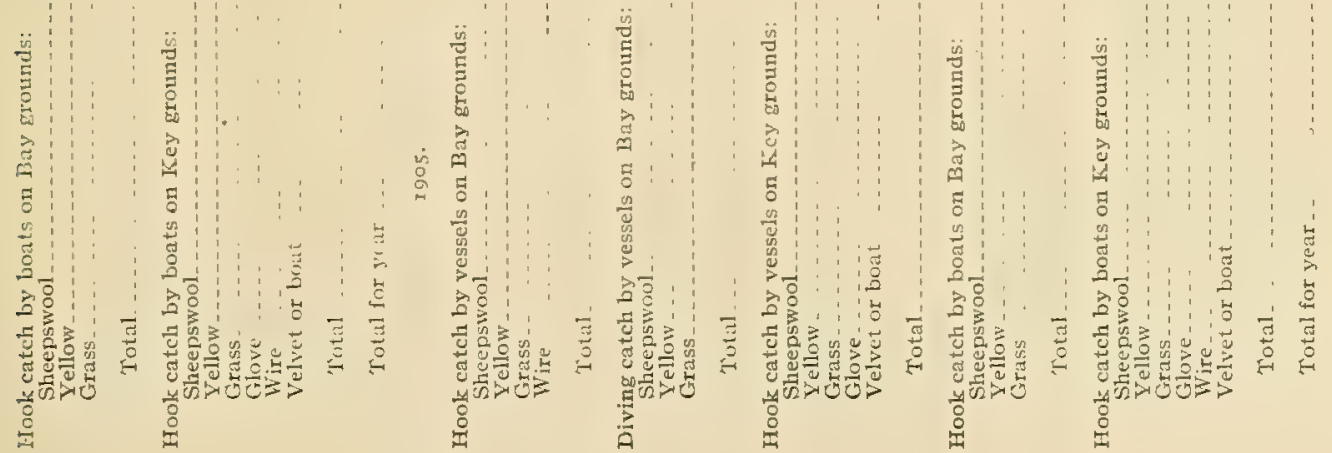




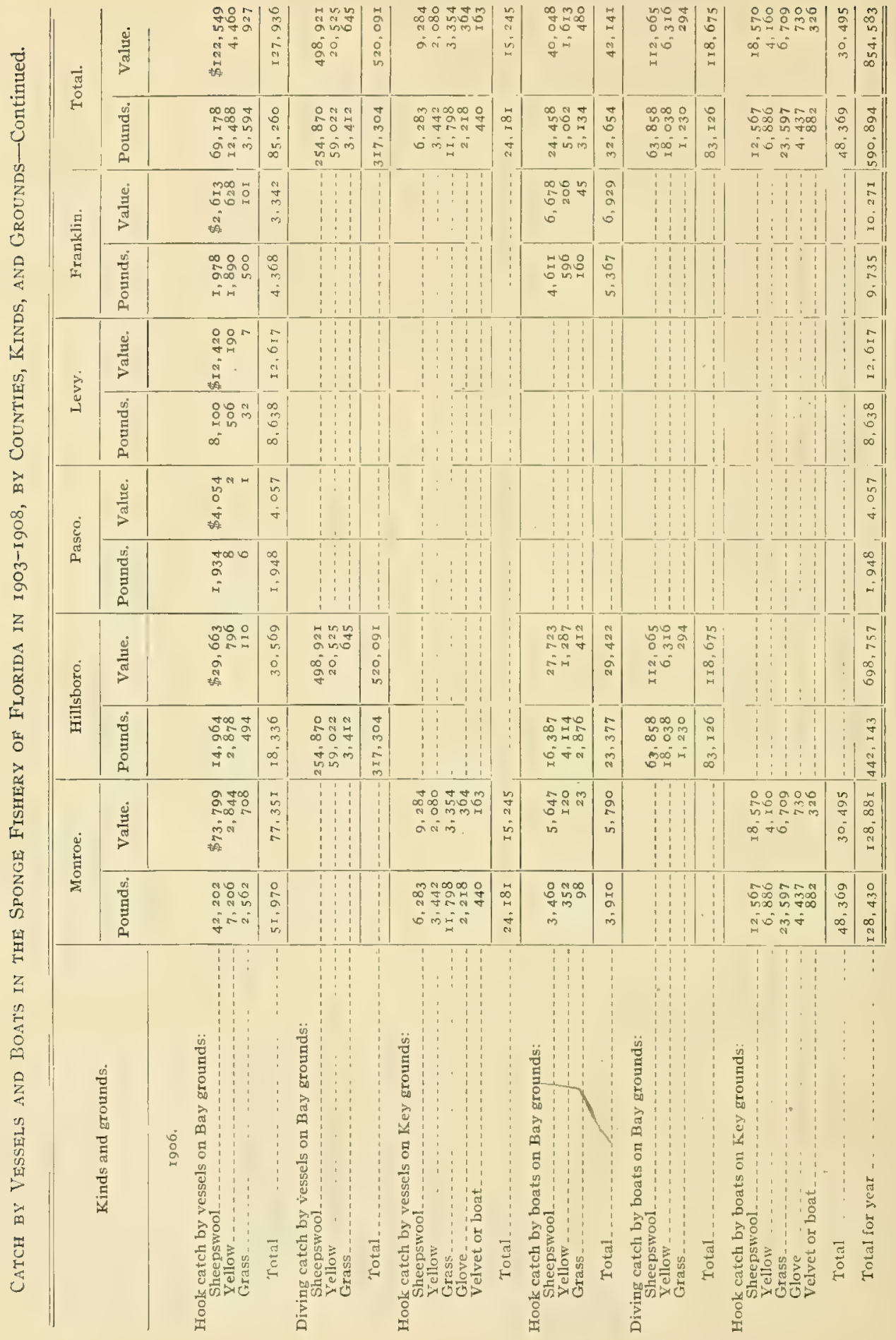


THE COMMERCIAL SPONGES AND THE SPONGE FISHERIES.

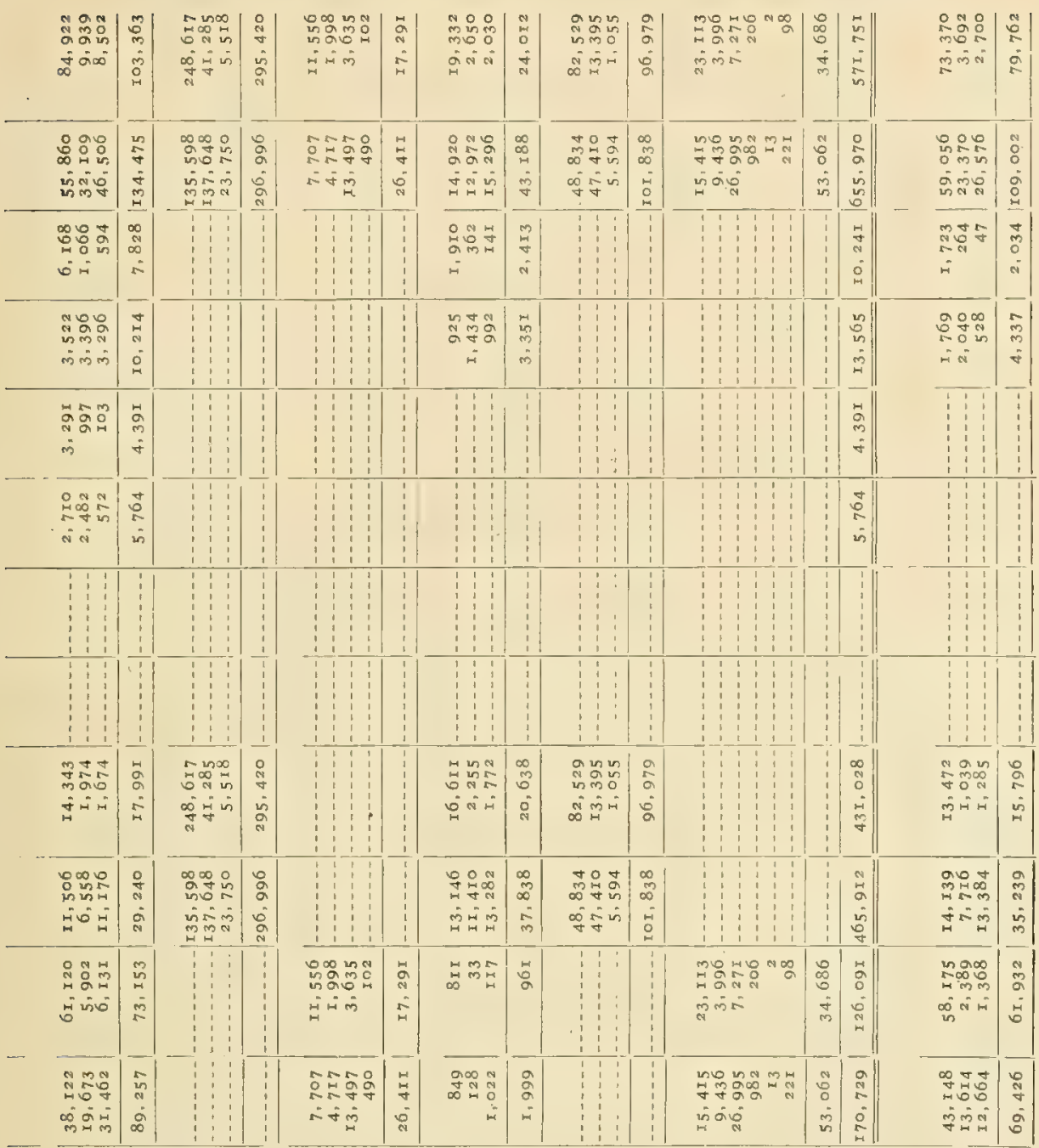

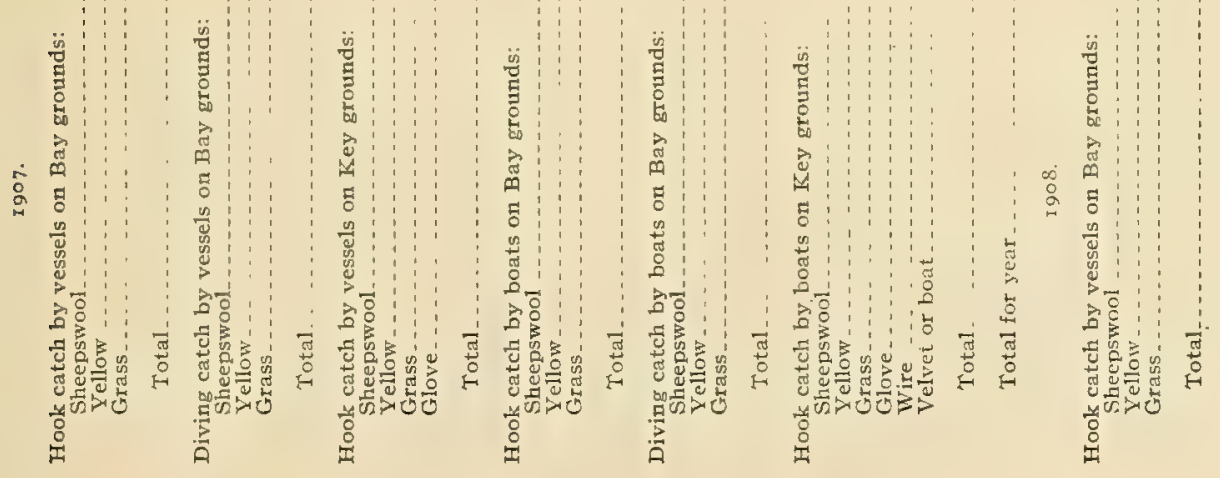




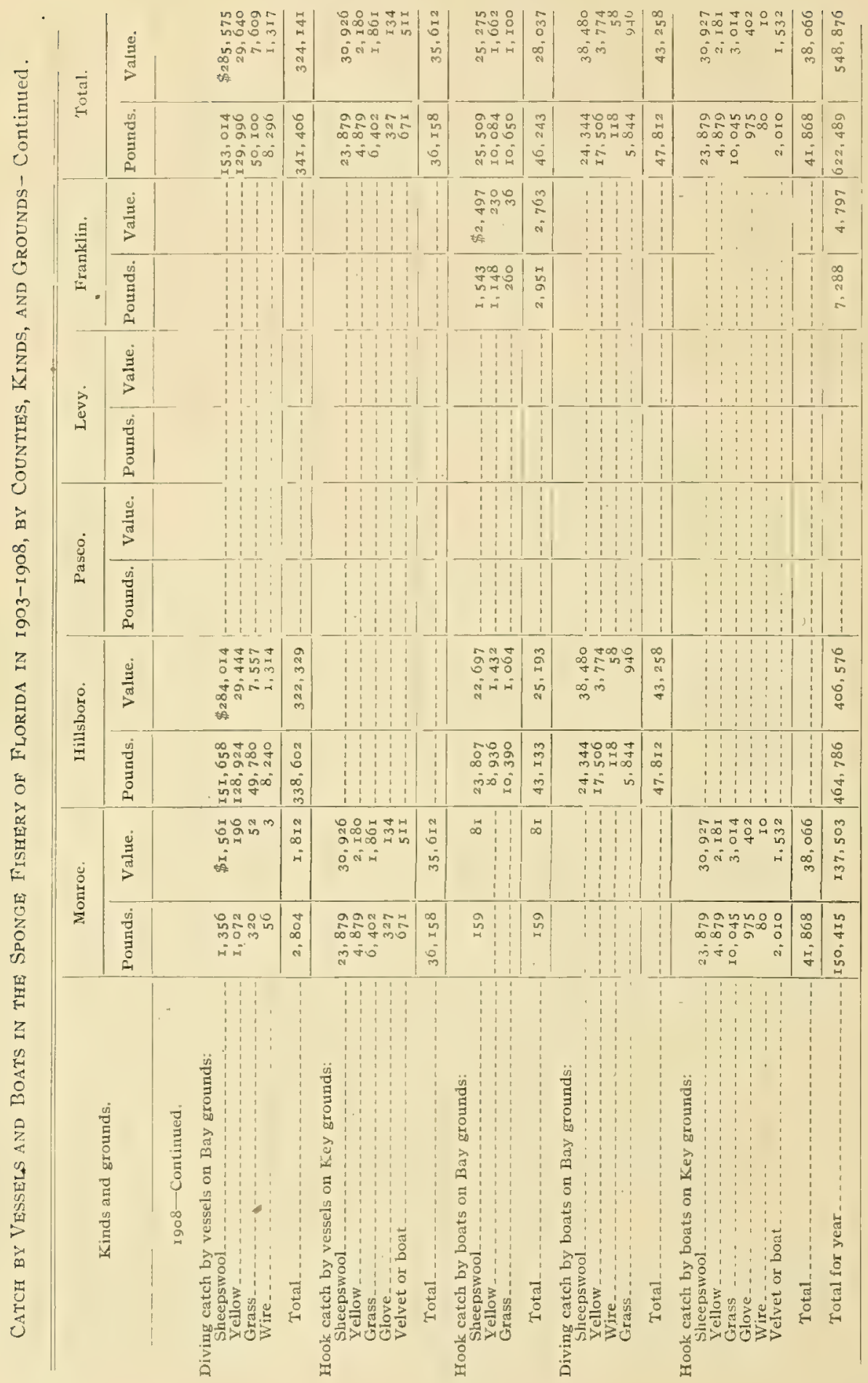


For purposes of comparison and to illustrate the statistical history of the Florida sponge fisheries, another series tables have been prepared. They embrace all years for which accurate returns are available. The data for I903 to I908, inclusive, are summaries of the preceding tables here first published, and for the years prior to 1903 are obtained from previous publications of the Bureau of Fisheries.

The returns of the investments in the sponge fisheries prior to I 900 are incomplete or inseparable from those in other fisheries, and the same statement applies to the personnel. The yield of the fisheries is known for a longer series of years, though the earlier returns are not so fully itemized as are those for the years beginning with I900. It will be observed that all of the tables indicate a general shrinkage in the fishery until 1905, when the success of the experiment with diving apparatus administered a stimulus and largely revolutionized the methods. Since that time there has been an increase in the total investment, the number of vessels employed, the personnel of the fishery, and especially in the volume and value of the catch, though the latter reached its maximum, so far as the sheepswool sponges are concerned, in I906. In that year the quantity of sheepswool sponges alone far exceeded that of all kinds in any previous year in the history of the fishery, and the value was greater than that of the entire yield of the fishery in any year before or since.

In 1907 and 1908 the production of sheepswool sponges fell between 35 and 40 per cent, and to an even greater extent in value. This retrogression in the production of the highest grade of sponges was due to legal restrictions placed on diving, which became operative in 1907.

Accompanying this decrease there has been an enormous increase in the production of the cheaper sponges, especially yellow and grass, and the entrance of the previously neglected wire sponge into the markets as a valuable product. The production of yellow sponges in 1908 was about fourfold that of 1905 , and about 50 per cent more grass sponges were put on the market, while 8,494 pounds of wire sponges, valued at $\$_{1,3} 85$, were marketed in 1908 , and the product of 1909 will much exceed this in quantity, with a value relatively much greater than in 1908 .

Diving apparatus has undergone a rapid increase, but it is probable that its maximum has now been nearly reached, and its future development will be slower. There was a steady decrease in the number of vessels and men employed in the hook fishery between 1900 and 1905 , and since that year the decreasehas been rapid. Between 1900 and 1908 the number of vessels and men employed in hooking each fell about 54 per cent, and the product decreased about 45 per cent. At the present time there are indications of an increase in this method of sponging, certain of the diving vessels manned by Greeks outfitting with hooks and dingeys for work during the summer, when diving is prohibited. 
INVESTMENT IN THE, SPONge Fishery OF Florida, EXcluding SPONGE Buytng, For A SERIES OF YEARS.

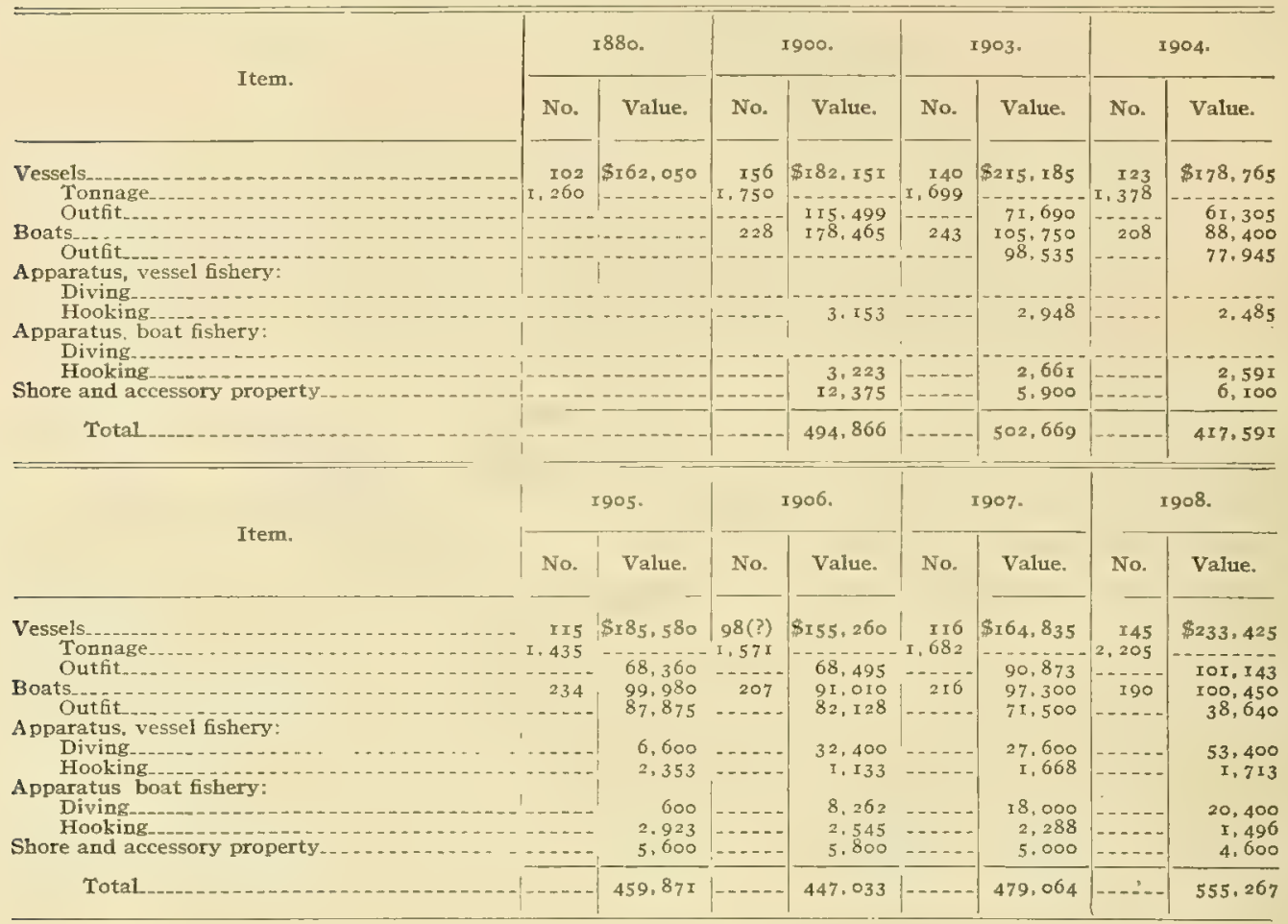

Craft Engaged in Hooking and Diving, Respectrvely.

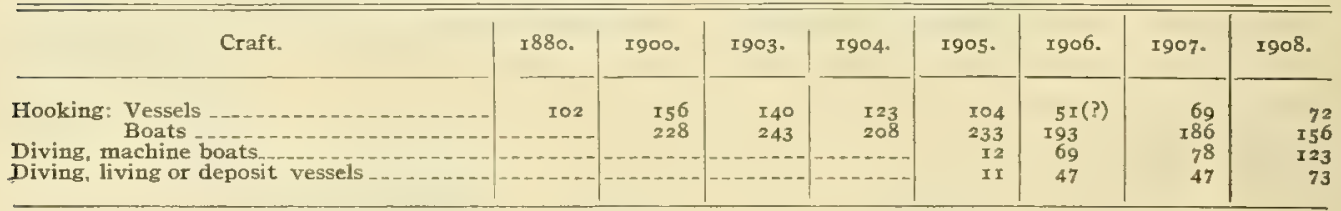

PeRsons EMPloyed in HoOking and Diving, Respectively.

\begin{tabular}{|c|c|c|c|c|c|c|c|c|}
\hline Craft. & 1880. & I900 & 1903. & 1904. & 1905. & 1906. & 1907. & rgo8. \\
\hline Hooking: Vessels & 828 & $\begin{array}{r}239 \\
874\end{array}$ & $\begin{array}{r}I 98 \\
887\end{array}$ & $\begin{array}{r}1,015 \\
762\end{array}$ & $\begin{array}{l}893 \\
850\end{array}$ & $\begin{array}{l}639 \\
633\end{array}$ & $\begin{array}{l}457 \\
542\end{array}$ & $\begin{array}{l}568 \\
410\end{array}$ \\
\hline Total & $\ldots$ & $2, \mathrm{II}_{3}$ & 2,085 & I. 777 & $I, 743$ & $I, 272$ & 999 & 978 \\
\hline Diving: Vessels $\ldots$ & 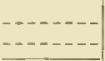 & 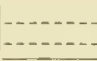 & 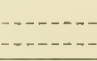 & 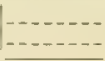 & $\begin{array}{r}\mathbf{I} 53 \\
\mathbf{1} 3\end{array}$ & $\begin{array}{l}746 \\
196\end{array}$ & $\begin{array}{l}669 \\
420\end{array}$ & $\begin{array}{l}945 \\
397 \\
\end{array}$ \\
\hline Total & 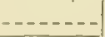 & $-\cdots+-\cdots$ & $-1 .-1$ & - & I66 & 942 & $I, 089$ & $x, 342$ \\
\hline Grand total & 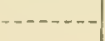 & $2, x \times 3$ & 2,085 & $I, 777$ & I. 909 & 2,214 & 2.088 & 2.320 \\
\hline
\end{tabular}


THE COMMERCIAL SPONGES AND THE SPONGE FISHERIES.

Products of the Florida Sponge Fishery, by Kind and Grounds.

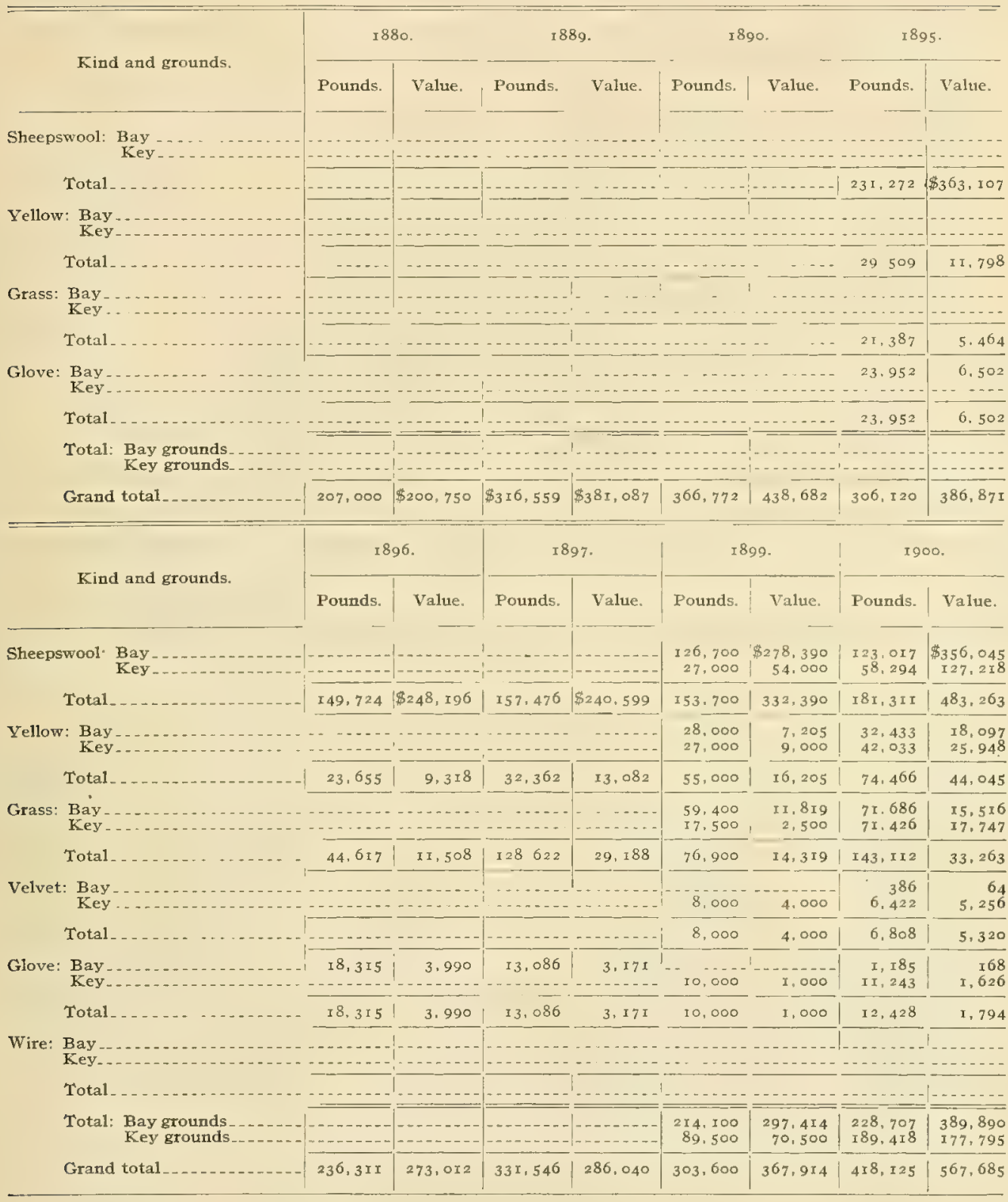


Products of the Florida Sponge Fishery, by Kind and Grounds - Continued,

\begin{tabular}{|c|c|c|c|c|c|c|c|c|}
\hline \multirow{2}{*}{ Kind and grounds. } & \multicolumn{2}{|c|}{$190 x}$. & \multicolumn{2}{|c|}{1902.} & \multicolumn{2}{|c|}{1903.} & \multicolumn{2}{|c|}{ I904. } \\
\hline & Pounds. & Value. & Pounds. & Value. & Pounds. & Value. & Pounds. & Value. \\
\hline 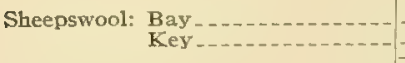 & & & 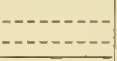 & $\left|\begin{array}{l}---n-n- \\
-\cdots-n-1\end{array}\right|$ & $\begin{array}{r}88,265 \\
31,069 \\
\end{array}$ & $\begin{array}{r}\$ 361,930 \\
49,632 \\
\end{array}$ & $\begin{array}{r}155,056 \\
39,883\end{array}$ & $\begin{array}{r}\$ 286,0 \times 7 \\
60,767 \\
\end{array}$ \\
\hline Total & 202,673 & $\$ 422,56 I$ & $\mathrm{I} 33,5 \mathrm{I} 8$ & $\$ 297,727$ & 219,334 & $41 I, 562$ & $\mathbf{1 9 4 . 9 3 9}$ & 346,784 \\
\hline 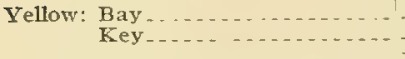 & & & 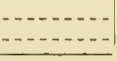 & 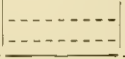 & $\begin{array}{r}54,153 \\
7,848 \\
\end{array}$ & $\begin{array}{r}14,602 \\
3,788 \\
\end{array}$ & $\begin{array}{l}38,294 \\
13,378 \\
\end{array}$ & $\begin{array}{r}10,827 \\
6,356 \\
\end{array}$ \\
\hline Total ................... & $62,5 \leq 2$ & 39.2901 & 56,787 & $31, I \mathbf{I} 3$ & $62,00 x$ & $\mathbf{8}, 390$ & 51,672 & $\mathbf{I} 7, \mathbf{I} 83$ \\
\hline Grass: $\begin{array}{l}\text { Bay . . . . . . . } \\
\text { Key } \ldots \ldots\end{array}$ & - - - - - - - & 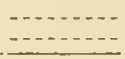 & 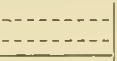 & 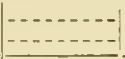 & $\begin{array}{l}60,272 \\
23,109\end{array}$ & & $\begin{array}{l}33,386 \\
27,886 \\
\end{array}$ & $\begin{array}{l}5,191 \\
4,350 \\
\end{array}$ \\
\hline Total $\ldots \ldots \ldots$ & 108.748 & 24,210 & 140,682 & 29.765 & 83,381 & 14,794 & 61,272 & $9.54 I$ \\
\hline $\begin{array}{l}\text { Velvet: Bay } \ldots \ldots \ldots \\
\text { Key } \ldots \ldots\end{array}$ & & & & $\mid \begin{array}{c}n-1 \\
-n-n-n-1\end{array}$ & 1,715 & 862 & 2,637 & $\mathrm{I}, 497$ \\
\hline Total $\ldots \ldots \ldots$ & 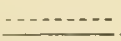 & 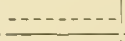 & 8,307 & 4.660 & I. 7 I 5 & 862 & 2.637 & $\mathrm{r}, 497$ \\
\hline $\begin{array}{l}\text { Glove: Bay } \ldots \ldots \\
\text { Key }\end{array}$ & $\begin{array}{r}2 x, 627 \\
-\cdots \\
\end{array}$ & $\begin{array}{c}6,679 \\
\end{array}$ & 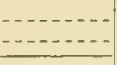 & - & $I I, 484$ & $r .738$ & $8,78_{3}$ & 1.164 \\
\hline Total $\ldots \ldots \ldots \ldots$ & 21.627 & 6.679 & 7.365 & I. III & II. 484 & I. 738 & 8,783 & I. I 64 \\
\hline $\begin{array}{l}\text { Wire: Bay ....... } \\
\text { Key_... }\end{array}$ & 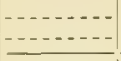 & & (n) & $\mid-\cdots-\cdots-\cdots$ & 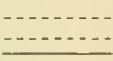 & (-n- & 98 & 16 \\
\hline Total. . & -...- & (1....... & 230 & 46 & - n & -......... & 98 & I6 \\
\hline $\begin{aligned} \text { Total: } & \text { Bay grounds } \ldots . . . \\
& \text { Key grounds...... }\end{aligned}$ & & & $\underline{-\cdots-1}$ & 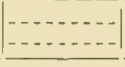 & $\begin{array}{r}302,690 \\
75,225 \\
\end{array}$ & $\begin{array}{r}386,253 \\
61,093 \\
\end{array}$ & $\begin{array}{r}226,736 \\
92.665 \\
\end{array}$ & $\begin{array}{r}302,035 \\
74, \times 50 \\
\end{array}$ \\
\hline Grand total $\ldots \ldots$ & 395,560 & 492,740 & 346,889 & 364,422 & 377,915 & 447,346 & $319,40 x$ & $376, \times 85$ \\
\hline \multirow{2}{*}{ Kind and grounds. } & \multicolumn{2}{|c|}{1905.} & \multicolumn{2}{|c|}{ I906. } & \multicolumn{2}{|c|}{ r907. } & \multicolumn{2}{|c|}{1908.} \\
\hline & Pounds. & Value. & Pounds. & Value. & Pounds. & Value. & Pounds. & Value. \\
\hline $\begin{array}{l}\text { Sheepswool: Bay } \\
\text { Key }\end{array}$ & $\begin{array}{r}173,721 \\
61,840 \\
\end{array}$ & $\begin{array}{r}\$ 408,322 \\
75,122 \\
\end{array}$ & $\begin{array}{r}4 \mathrm{I} 2,364 \\
18,850 \\
\end{array}$ & $\begin{array}{r}\$ 77,583 \\
27,854 \\
\end{array}$ & $\begin{array}{r}255,212 \\
23,122 \\
\end{array}$ & $\begin{array}{r}\$ 435,400 \\
34,669 \\
\end{array}$ & $\begin{array}{r}261,923 \\
47,75^{8} \\
\end{array}$ & $\begin{array}{r}\$ 222,700 \\
6 \mathrm{r}, 853 \\
\end{array}$ \\
\hline Total $\ldots$ & 235,561 & 483,444 & $43 I, 2 I 4$ & 801,437 & 278,334 & 470,069 & $309,68 \mathrm{I}$ & 484,553 \\
\hline $\begin{array}{l}\text { Yellow: Bay } \\
\text { Key }\end{array}$ & $\begin{array}{l}3 I, 3 I 2 \\
I 3,758 \\
\end{array}$ & $\begin{array}{r}12,199 \\
7,035 \\
\end{array}$ & $\begin{array}{l}94,610 \\
I 0,328 \\
\end{array}$ & & $\begin{array}{r}230,139 \\
14,153 \\
\end{array}$ & $\begin{array}{r}67,269 \\
5,994 \\
\end{array}$ & $\begin{array}{r}180,956 \\
9,758 \\
\end{array}$ & $\begin{array}{r}38.768 \\
4.361 \\
\end{array}$ \\
\hline Total $\ldots$ & 45,070 & 19,234 & 104,938 & 39.154 & 244,292 & 73.263 & 190,714 & 43,129 \\
\hline Grass: Bay ${ }_{\text {Key }} \ldots \ldots \ldots$ & $\begin{array}{l}26,9 \text { I I } \\
40,530\end{array}$ & $\begin{array}{r}4.485 \\
1 \mathrm{r}, 95 \mathrm{I} \\
\end{array}$ & $\begin{array}{l}I I, 370 \\
35,395 \\
\end{array}$ & $\begin{array}{r}2,346 \\
10,063 \\
\end{array}$ & $\begin{array}{l}91, \text { I } 46 \\
40,492 \\
\end{array}$ & & $\begin{array}{l}93,170 \\
16,447\end{array}$ & $\begin{array}{r}12,355 \\
4,875 \\
\end{array}$ \\
\hline Total $\ldots \ldots \ldots \ldots$ & 67,441 & $\mathrm{I} 6,436$ & 46,765 & 12,409 & $I 3 I, 638$ & $28,0 I x$ & 109,617 & 17,230 \\
\hline 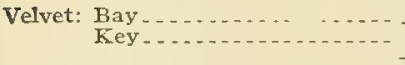 & 2.377 & 1,350 & 1,322 & 489 & 221 & 98 & $2,68 \mathrm{I}$ & 2,043 \\
\hline Total $\ldots$ & 2.377 & I. 350 & I, 322 & 489 & $22 \mathrm{I}$ & 98 & 2,681 & 2.043 \\
\hline 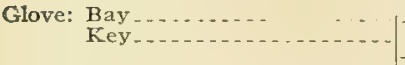 & 13,161 & 2,210 & 6.655 & $\mathbf{I}, 094$ & $x, 472$ & 308 & 1,302 & 536 \\
\hline Total $\ldots \ldots$ & 13,161 & 2,210 & 6.655 & I. 094 & $I, 472$ & 308 & I, 302 & 536 \\
\hline Wire: Bay ....... & $\begin{array}{r}142 \\
350 \\
\end{array}$ & $\begin{array}{r}164 \\
88\end{array}$ & & & 13 & 2 & $\begin{array}{r}8,414 \\
80 \\
\end{array}$ & $\begin{array}{r}1.375 \\
10 \\
\end{array}$ \\
\hline Total & I. 492 & 252 & 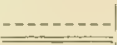 & .......- & 13 & 2 & 8,494 & I, 385 \\
\hline $\begin{array}{l}\text { Total: Bay grounds } \ldots \ldots \\
\text { Key grounds } \ldots \ldots\end{array}$ & $\begin{array}{r}233,086 \\
\mathbf{1 3 2}, 0 \leq 6 \\
\end{array}$ & $\begin{array}{r}425,170 \\
97,756 \\
\end{array}$ & $\begin{array}{r}518,344 \\
72,550 \\
\end{array}$ & $\begin{array}{r}808,843 \\
45,740 \\
\end{array}$ & $\begin{array}{r}576,497 \\
79,473 \\
\end{array}$ & $\begin{array}{r}519,774 \\
51,977 \\
\end{array}$ & $\begin{array}{r}536,049 \\
86,440 \\
\end{array}$ & $\begin{array}{r}473,823 \\
75,053 \\
\end{array}$ \\
\hline Grand total $\ldots \ldots$ & 365,102 & 522,926 & 590,894 & $854,5^{8} 3$ & 655,970 & 571,751 & 622,489 & 548,876 \\
\hline
\end{tabular}


Catch on Bay Grounds, by Apparatus.

\begin{tabular}{|c|c|c|c|c|c|c|c|c|}
\hline & \multicolumn{2}{|c|}{ I 905.} & \multicolumn{2}{|c|}{ I906. } & \multicolumn{2}{|c|}{1907.} & \multicolumn{2}{|c|}{ т908. } \\
\hline & Pounds. & Value. & Pounds. & Value. & Pounds. & Value. & Pounds. & Value. \\
\hline $\begin{array}{l}\text { Sheepswool: Diving. } \\
\text { Hellow: Diviug } \\
\text { Hooking } \\
\text { Grass: Diving } \\
\text { Wire: Dooking Diving } \\
\text { Hooking }\end{array}$ & $\begin{array}{r}9,250 \\
164,471 \\
572 \\
30,740 \\
172 \\
26,739 \\
1,142\end{array}$ & $\begin{array}{r}\$ 47,506 \\
360,816 \\
225 \\
\mp 1,974 \\
30 \\
4,455 \\
164\end{array}$ & $\begin{array}{r}318,728 \\
93,636 \\
77,060 \\
17,550 \\
4,642 \\
6,728 \\
\end{array}$ & $\begin{array}{r}\$ 610,986 \\
162,597 \\
26,841 \\
6,073 \\
939 \\
1,407 \\
\end{array}$ & $\begin{array}{r}184,432 \\
70,780 \\
185,058 \\
45,081 \\
29,344 \\
61,802 \\
\end{array}$ & $\begin{array}{r}\$ 331,146 \\
104,254 \\
54,680 \\
12,589 \\
6,573 \\
10,532 \\
\end{array}$ & $\begin{array}{r}177,354 \\
84,565 \\
147,496 \\
33,454 \\
55,944 \\
37,226 \\
8,414 \\
\end{array}$ & $\begin{array}{r}\$ 324,055 \\
98,645 \\
33,4 x 4 \\
5,354 \\
8,555 \\
3,800 \\
x, 375 \\
\end{array}$ \\
\hline Total: Diving & $\begin{array}{r}9,994 \\
223,092\end{array}$ & $\begin{array}{r}47,76 \text { I } \\
377,409\end{array}$ & $\begin{array}{l}400,430 \\
\text { II } 7,914\end{array}$ & $\begin{array}{l}638,766 \\
170,077\end{array}$ & $\begin{array}{l}398,834 \\
177,663\end{array}$ & $\begin{array}{r}392,399 \\
127,375\end{array}$ & $\begin{array}{l}389,208 \\
I_{55}, 245\end{array}$ & $\begin{array}{l}367,399 \\
107,799\end{array}$ \\
\hline Grand total & 233,086 & 425,170 & $5 \pm 8,344$ & 808,843 & 576,497 & 519,774 & 544,453 & $475, \times 98$ \\
\hline
\end{tabular}

NoтE. - All sponges from the Bay prior to 1905 and all from the Keys to date were taken by hookers.

\section{FOREIGN SPONGE TRADE OF THE UNITED STATES.}

The foreign sponge trade of the United States has attained considerable proportions, amounting to $\$ 735,57 \mathrm{I}$ during the year ended June 30, 1907 . The growth in the imports of sponges and the sources from which they are derived are shown in the following table:

IMPORTS OF FOREIGN SPONGES INTO THE UNITED Stateis.

\begin{tabular}{|c|c|c|c|c|c|c|}
\hline Year. & $\begin{array}{l}\text { North } \\
\text { America. }\end{array}$ & Europe. & Asia. & Oceania. & Africa. & Total. \\
\hline 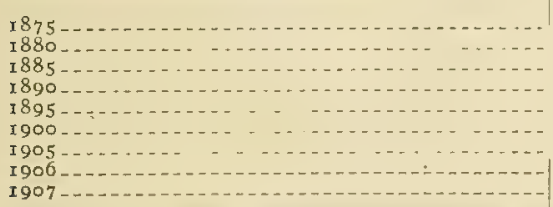 & $\begin{array}{r}\$ 454,070 \\
453,137 \\
374,418\end{array}$ & $\begin{array}{l}\$ 88,444 \\
107,877 \\
113,830\end{array}$ & $\begin{array}{r}\$ 18 \mathrm{x} \\
3,05 \mathrm{I} \\
\times 78\end{array}$ & 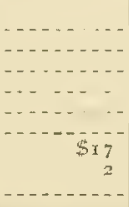 & (12- & $\begin{array}{r}\$ 118,229 \\
197,431 \\
333,774 \\
416,718 \\
350,008 \\
536,303 \\
542,712 \\
564,098 \\
488,426\end{array}$ \\
\hline
\end{tabular}

The decrease in 1907 was in the imports from Cuba and the Bahamas and was due largely to the heavy crop of domestic sponges in the preceding year. The imports of Mediterranean sponges, with which our own product does not so sharply compete, exhibited an increase. follows:

During the past five years the exports of domestic sponges have been as EXPORTS OF SPONGES FROM THE UNITED STATES.

\begin{tabular}{|c|c|c|c|c|c|c|c|c|}
\hline Year. & İurope. & North & South & Asia. & Oceania. & Africa. & & \\
\hline $\begin{array}{l}\text { I903 } \\
\text { I904 } \\
\text { I905 } \\
\text { I906 } \\
\text { I907 }\end{array}$ & $\begin{array}{l}\$ 42,545 \\
23,472 \\
11,645 \\
27,481 \\
99,686\end{array}$ & $\begin{array}{r}\$ 6,553 \\
9,700 \\
4,773 \\
I 4,32 I \\
I I, 2 I 7\end{array}$ & $\begin{array}{l}\$ 652 \\
653 \\
550 \\
544 \\
506\end{array}$ & $\begin{array}{r}\$ 3 I I \\
I, 728 \\
I, 386 \\
I, 359 \\
2,4 I 3\end{array}$ & $\begin{array}{r}\$ 245 \\
I, 033 \\
26 \\
22 I \\
532\end{array}$ & 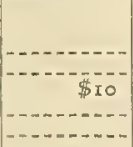 & $\begin{array}{r}\text { Pounds. } \\
95, \text { I59 } \\
64,214 \\
31,700 \\
50,953 \\
\pm 36,301\end{array}$ & $\begin{array}{l}\text { Value. } \\
\$ 50,306 \\
36,646 \\
\text { I8, } 390 \\
43,926 \\
\text { I I } 4,354\end{array}$ \\
\hline
\end{tabular}


The heavy increase in the exports for 1907 was also due to the large crop in the preceding year, which for the time being glutted the American market and materially reduced the price of the better grades of sponges. Ordinarily it is the lower grades only that are exported.

In addition to the foregoing sponges of domestic origin there were exported foreign sponges, principally Bahaman and Cuban, to the value of $\$ 553,452$ in I905, $\$ 152,675$ in 1906 , and $\$ 132,79 \mathrm{I}$ in 1907 , most of them going to France, Great Britain, Germany, and other countries of Europe and to Canada. About 90 per cent of the export trade is in New York, and practically all of the rest in various ports on the Canadian border.

\section{OTHER WESTERN ATLANTIC FISHERIES.}

\section{BAHAMA ISLANDS.}

The sponge fisheries of the Bahamas date from $\mathrm{r} 84 \mathrm{I}$, when, it is related, the value of the native product was recognized by a French sponge dealer who had been wrecked in the archipelago, and who shipped a sample lot to Paris.

Sponge grounds. -The principal beds lie on Great and Little Bahama banks, Exuma Bank, and the shoals about Eleuthera, and differ considerably in their product. The sheepswool and velvet sponges from Little Bahama Bank, especially in the vicinity of Abaco Island, are known as Abaco wool and velvet, as distinguished from "Nassau" or "Cay" sponges, coming from other parts of the Bahamas. They are soft and fine, the velvet being the best of that variety known to commerce, are packed separately, and bring a higher price in the market. It is stated that owing to the demand for these sponges and the consequent overfishing, the beds have been more or less exhausted and many of the sponges now sold as Abaco wool and velvet are in reality selected specimens from other grounds.

The Great Bahama Banks, which extend north, west, and south of Andros Island and along the Old Bahama Channel, produce large quantities of wool, velvet, yellow, and grass sponges, but these are generally open in texture, coarse, and weak, especially those from the southern and southeastern parts of the bank. Many of them grow on gorgonians (sea feathers) or corals and are frequently pierced by large holes, which mar an otherwise spherical shape. In this region all of the four varieties named generally have the lamellæ more or less thickened to form cushions or flat-ended brushes, so that they all have surfaces more or less remotely resembling that of velvet sponges. The region from which these sponges come is known to the spongers as "The Muds."

The banks about Eleuthera, which were discovered about i $88_{3}$, produce a somewhat better quality of sheepswool, but not equal to those of Little Bahama Bank. 
The best of the grass sponges come from Long, Acklin, and Turks islands in the southeastern part of the Bahamas, but as a rule they are packed with those from other localities. Though the larger part of the banks lie far beyond the marine league, the Bahama government assumes jurisdiction for purposes of protection and prohibits the operation of foreign sponging vessels. In 1902 or 1903, several vessels from Key West were seized on Great Bahama Bank and the masters and several members of the crews were imprisoned at Nassau, but were ultimately released. The men were well satisfied to secure their own release and escape the confiscation of their vessels, and no test was made of the legality of the procedure.

From the view point of the perpetuation of the sponge beds it is not improbable that the Bahama govenment is justified in adopting these measures and others with like purpose, for as long ago as 1875 it was claimed that the beds were becoming exhausted by overfishing. The same claim is made to-day, especially, with regard to the more desirable kinds, and in view of the increased demands on the beds in recent years it is probably warranted, notwithstanding that the product has steadily grown in quantity and value.

In 1849 the total exports of sponges were valued at $\$ 10,752$, and between 1850 and 1853 the average annual exportation was valued at $\$ 50,052$. The averages at other periods have been as follows: I 855 to $1858,255,300$ pounds, valued at $\$ 54,097 ; 1866$ and $1869,625,850$ pounds, valued at $\$ 164,900$; and from 1873 to 1875 , inclusive, 31 3,733 pounds, valued at $\$ 103,673$.

The exports in more recent years are shown in the table below:

EXPORTS OF SPONGES FROM THE BAHAMA ISLANDS, I $880-1905$.

\begin{tabular}{|c|c|c|c|c|c|}
\hline Year. & Pounds. & Value. & Year. & Pounds. & Value. \\
\hline 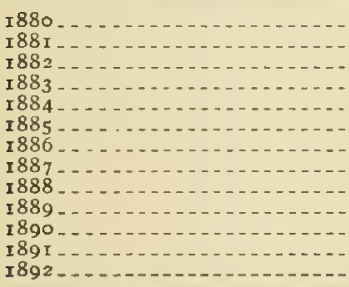 & $\begin{array}{r}429,400 \\
379,700 \\
612,500 \\
541,600 \\
I, 274,000 \\
808,200 \\
676,500 \\
622,300 \\
789,044 \\
703,163 \\
917,784 \\
987,400 \\
I, 011,200\end{array}$ & $\begin{array}{l}\$ 168,125 \\
I 47,207 \\
286,310 \\
244,216 \\
220,932 \\
254,498 \\
215,918 \\
229,118 \\
238,198 \\
251,598 \\
306,195 \\
284,607 \\
317,888\end{array}$ & $\begin{array}{l}\text { I893 } \\
\text { I894 } \\
\text { I895 } \\
\text { I896 } \\
\text { I897 } \\
\text { I898 } \\
\text { I899 } \\
\text { I900 } \\
\text { I901 } \\
\text { 1903 } \\
\text { I904 } \\
\text { I905 }\end{array}$ & $\begin{array}{r}844,300 \\
893,600 \\
965,200 \\
\text { I. } 365,900 \\
I, 228,047 \\
I, 207,683 \\
I .124,585 \\
I, 165,406 \\
I, 517,597 \\
I .515,626 \\
I, 407,958 \\
I, 486,128\end{array}$ & $\begin{array}{r}\$ 284,282 \\
286,901 \\
327,690 \\
393,291 \\
437,038 \\
472,933 \\
407,414 \\
505,462 \\
665,890 \\
506,310 \\
512,732 \\
551,702\end{array}$ \\
\hline
\end{tabular}

a IS months, January I, I901, to March 35, I902.

It will be observed from the foregoing that the exports have shown a steady increase during the past twenty-five years, and as practically the entire catch is shipped abroad the statistics cited can be regarded as an index of the yield of the fisheries. During the decade ending with I 889 the average annual product was 683,640 pounds; in that ending with 1899 it was $\mathrm{I}, 054,569$ pounds, while for five years ending with 1905 it was $1,350,993$ pounds. 
There is here no intrinsic evidence that the beds are being depleted, but in the absence of data showing the intensity of the fishery no conclusions of value can be reached. There are no details available which would permit a comparison of the catch per man, though there is unofficial authority for the statement that "about 3,000 men and boys" were employed in the fishery about I880, while official returns show that more than twice that many were employed in 1902 .

Methods of the fishery.--The methods of fishing for sponges in the Bahamas are essentially those which have been described as in use in Florida prior to the introduction of the diving machine in 1905, and the history of the development of the industry is parallel. Practically all of the sponges are taken by means of hooks, by poling and sculling, though a few are secured by wading and naked diving. The methods of curing and packing are the same as those employed in Florida and the entire product passes through the sponge exchange at Nassau.

In 1902 there were employed in the fishery 265 schooners of from 5 to 43 tons and 322 sloops of from I to 16 tons, in all 587 vessels with an aggregate tonnage of 5,952. Attached to these vessels were 2,517 dingeys and crews numbering 5,517 men and boys. In addition there were engaged in the shore fisheries 29I boats and 445 men and boys, while the packing houses employed 258 persons.

The sponge fishery is the most important industry of the islands and over half of the product is shipped to the United States. The following statement shows the exports for 1905 :

ExPORTS OF SPONGES From THE BaHAMA ISLANDS IN I905.
Pounds.

CUBA.

Sponge grounds. -The sponge beds of Cuba are found on both the north and south coasts, the latter supporting the more important and productive fishery. There are a few inferior sponges, principally a hard quality of velvet, on the north coast of Pinar del Rio, but the productive beds of the north coast are all among the numerous keys between Cardenas and Nuevitas. These beds were known before the discovery of the Batabano grounds and were resorted to by the Bahama spongers under license from the Spanish authorities. They lie in shallow water within and about the line of keys which skirts the Nicholas and Old Bahama channels, opposite the important beds of the Great Bahama Bank. It is stated that these beds have become greatly depleted by overfishing and 
they now produce but about 20 per cent of the total product of the Cuban fishery. This region is the source of practically all of the Cuban reef, hardhead, and silk grass sponges. Sheepswool and velvet are now comparatively scarce, but the former are stronger and better than the product of the south coast. Certain vessels from Key West which visited this region in I 898 or I 899 reported comparatively few sponges and returned with practically none. Caibarien is the principal center of this fishery, but some of the product is sold in Cardenas and Nuevitas. There are one or two buyers located on the coast, but it is also periodically visited by buyers from Batabano.

The most important beds of the south coast lie in the vicinity of Batabano, between the main island and the Isle of Pines, from Cayos de Felipe to Cabeza del Este. This region is dotted with numerous small islands, keys, and rocks, and over most of the bottom the depth is less than 3 fathoms and in very few places does it reach a maximum of 6 fathoms. Outside of the banks in the Caribbean Sea, however, the bottom slopes rapidly to profound depths. Sponges are also found among the keys and shoals off Santa Clara Province, but no commercial fishery has been developed in that locality.

The grounds off Batabano were discovered in $\mathrm{x} 884$ and an attempt was made to secure a concession monopolizing the exploitation of the beds. Fortunately this was frustrated and the beds were reserved as a common fishery. In I89I there were upward of I8o spongers at Batabano alone, and the yield of the fisheries in that region was valued at about \$I ro,ooo per year. Since then there has been a heavy increase in the yield and the annual product is valued at about $\$ 275,000$ to $\$ 350,000$, as based on the declarations for export. As a general rule, however, the imports into the United States are subjected to revaluation, and it is difficult to arrive at a definite estimate of the first value of the fishery to the spongers.

The exports, which represent the entire catch for both coasts, for the fiscal years ending June 30 , r903-1906, have been as follows:

EXPORTS OF SPONGES FROM CUBA, I903-IgO6.

\begin{tabular}{|c|c|c|c|c|c|c|c|c|}
\hline \multirow{2}{*}{ Exported to- } & \multicolumn{2}{|c|}{ I903. } & \multicolumn{2}{|c|}{ I904. } & \multicolumn{2}{|c|}{1905.} & \multicolumn{2}{|c|}{$x 906}$. \\
\hline & Pounds. & Value. & Pounds. & Value. & Pounds. & Value. & Pounds. & Value. \\
\hline $\begin{array}{l}\text { United States... } \\
\text { France. } \\
\text { United Kingdom } \\
\text { Spain_. } \\
\text { Germany } \\
\text { British West Indies. } \\
\text { Canada } \\
\text { Holland... } \\
\text { Belgium } \\
\text { Italy } \\
\text { Mexico }\end{array}$ & $\begin{array}{r}381,462 \\
357,410 \\
47,934 \\
48,726 \\
20,288 \\
1,243 \\
2,200 \\
3,148 \\
\end{array}$ & $\begin{array}{r}\$ 146,076 \\
210,589 \\
13,470 \\
13.819 \\
7.500 \\
1,800 \\
1,000 \\
850 \\
\\
\end{array}$ & $\begin{array}{r}332,534 \\
384,478 \\
38,612 \\
35,607 \\
57,449 \\
2,285 \\
1,712 \\
392\end{array}$ & $\begin{array}{r}\$ 155,099 \\
231,140 \\
12,242 \\
9.398 \\
23.581 \\
1,200 \\
368 \\
280\end{array}$ & $\begin{array}{r}366,388 \\
185,427 \\
19,897 \\
18,301 \\
11,730 \\
13,900 \\
2,055 \\
2,013 \\
\end{array}$ & $\begin{array}{r}\$ 200,296 \\
\times 14,438 \\
7,764 \\
8,319 \\
6.028 \\
2,952 \\
840 \\
750\end{array}$ & $\begin{array}{r}325,872 \\
195,683 \\
23,008 \\
26,514 \\
19,883 \\
110 \\
\end{array}$ & $\begin{array}{r}\$ 161,622 \\
133,062 \\
8,818 \\
13.400 \\
9.629 \\
40 \\
\ldots . . . \\
\end{array}$ \\
\hline Total & 862,4 II & 395,104 & 853.069 & 433,308 & $6 \times 9,7 \times 1$ & $34 \mathrm{r}, 3^{87}$ & 591,070 & 326,571 \\
\hline
\end{tabular}


I have not been able to obtain reliable data showing the quantity of sponges shipped in preceding years, but for 1900 to 1902 , inclusive, the average annual value of the exports was about $\$ 460$,ooo. It will be seen, therefore, that during the past four or five years there has been a steady shrinkage in the value of the catch and a still greater falling off in its quantity. Between 1903 and 1906 the quantity of sponges exported, and presumably the quantity fished, shrunk over 30 per cent.

Methods of the fishery.-After experiment with the scaphander and naked diving, both of which proved expensive or inefficient, and with a species of grapnel dragged over the bottom, the method of hooking, essentially similar to that practiced in Florida and the Bahamas, finally became established as the most satisfactory and effective and is now generally employed, though a few sponges are taken in the shoaler waters by wading.

The first spongers were former Spanish sailors from the Balearic Islands, but there are now a number of Greeks and Cubans engaged in the fishery. The sponges are cleaned as in the United States and are then strung on cords, each holding a dozen sponges of uniform size or half that number of larger individuals.

They are sold at auction by the merchant owning or outfitting the vessel instead of by the master, as in Florida, being hung up in festoons for inspection for some time before the sale. There is no regular sponge exchange, as at Nassau and more recently at Tarpon Springs, the sales being conducted in some convenient coffee house, where the buyers congregate and hand in the bids on slips of paper, the highest bidder securing the lot. The method of stringing the sponges by sizes and count which is established by law is more systematic than that followed in Florida, and the buyer can more readily determine the value of the cargoes offered for sale.

\section{MINOR FISHERIES.}

Honduras.- Sponges are found along the entire coast of British Honduras, in the shallow waters about the numerous islands, rocks, and banks, but they are inferior in quality and not many are placed on the markets. The varieties found are sheepswool, velvet, and grass, the latter almost worthless. Many of the sheepswool, velvet, and grass sponges grow attached to staghorn corals and gorgonians, the removal of which leaves large holes penetrating the cured sponge and detracting from its value. Others are irregular from growing among marine growths or on the sides of rocks. The characteristics of some specimens, however, lead to the expectation that better grades will be found in deeper water. The velvet sponge in particular has some good qualities.

The value of the exports of sponges to the United States during recent years has been as follows: I903, \$I,218; 1904, \$50; 1905, \$915; 1906, \$I,949, and $1907, \$ 2,33 \mathrm{I}$. 
Nicaragua.-A very few sponges are produced on the coast of Nicaragua and other Central American countries. In 1905, the exports to the United States were valued at $\$ 50$.

Mexico. - The sponge beds of Mexico lie on the north and east coast of Yucatan, on Campeche Banks and about Cozumel Island. The beds which have been exploited lie in very shallow water and the sponges are very inferior, but it is said that there are better grades in the deeper water toward the southern end of the east coast. The exportation from Mexico is very small, in I906 amounting to but $\$ 2$ I 8 on shipments to the United States and $\$ 250$ on shipments to France. During the five years from I 903 to 1907 , inclusive, the total exports to the United States were valued at but \$I,2I 4. A very few American vessels have sponged off the Mexican coast in recent years, but the value of their catch is not definitely known. Several years ago a vessel with two diving boats operated for three seasons off Cozumel. Large yellow sponges were found in abundance, but the few sheepswool sponges taken were so much inferior to those of Florida that the venture never paid.

Colombia.- The United States consul at Cartagena says, in I907:

The bay of Cartagena is rich in sponge beds, and the local fishers for sponges find some fine in quality and large in size. These are handled in a crude way by the "bumboat" 'men only, and sold alongside vessels in the harbor, no effort being made to export them in a business-like manner.

The Consular Reports for 1903 noted the granting of concessions on both the Atlantic and Pacific coasts which included the sponge fisheries, but nothing is known of the value of the beds. The only Colombian sponge of which the author has definite knowledge is a hardhead closely resembling that from Honduras. This is said to be very abundant. The writer ventures to predict that the sponge fauna will be eventually found to embrace all of the principal kinds of American commercial sponges, though it is doubtful whether they will prove of very high quality.

Venezuela.-Weil states that there are sponges on the coast of Venezuela, but that they are hard, incompressible, not very porous, and practically worthless.

Jamaica.-A few velvet sponges, elsewhere described in this paper, are taken from the waters of Jamaica, but the fishery is of comparatively little importance.

Santo Domingo. - The principal sponge beds are about the Island of Gonaves, in the Republic of Haiti. They produce velvet and reef sponges which are both inferior in quality and generally poorly prepared for the market. The spongers are Greeks, 5 or 6 in number, and fishing but occasionally produce sponges with a value of but $\$ 600$ or $\$ 800$ per year.

Commercial sponges similar in general to those of other parts of the Caribbean are known zoologically from Porto Rico, the Danish West Indies, and other of the Lesser Antilles. 


\section{SPONGE FISHERIES OF THE MEDITERRANEAN AND CONTIGUOUS WATERS.}

The Mediterranean produces the finest and most valuable sponges known to commerce, but they differ greatly in quality in different regions. Broadly speaking, the commercial varieties are five in number - the Turkey cup, toilet, zimocca, elephant ear, and honeycomb; but these are subdivided in the sponge trade into numerous sorts in accordance with the localities from which they come and the means by which they are taken, and then are still further distinguished by grades of quality and even by the nationality of the fishermen who take them. Sponges are found along the European, Asiatic, and African shores from Gibraltar to Port Said, but it is in certain places only that they exist in such numbers as to support a fishery. These regions will be taken up for consideration in more detail hereafter.

West of Sicily and Cape Bon, in Africa, the fishery is unimportant and almost negligible, and the finer varieties, the toilet and cup sponges, are practically absent. To the eastward of a line between the places mentioned the fishery is highly important and one of the most valuable in the Mediterranean. Owing to long-continued overfishing the supply from the Adriatic, the Egean, and the Levant is smaller than formerly, and to meet the increased demand of the markets there has been in the last twenty-five to thirty years a most important development of the fisheries of the African Coast from Alexandria to the western frontier of Tunis.

The very finest grades come from the Levant, and the quality falls toward the westward along both the north and south shores. In the waters contiguous with the Mediterranean Sea, commercial sponges are known from the Dardanelles, the Sea of Marmora, the Bosphorus, and the adjacent parts of the Black Sea, but the quality appears to become progressively lower and the quantity less in the order named. In the Red Sea there are said to be vast quantities of sponges, but their quality is inferior and their value small.

It is difficult to form more than an estimate of the value of the Mediterranean sponge fisheries, owing to the nomadic habits of most of the fishermen. The Greeks, both national and Turkish, carry on their operations not only at home but in almost every part of the sea which promises anything like a lucrative return. The Italians, while not quite so wandering, extend their operations across the Mediterranean to the Tunisian coast, and both they and the Greeks vary somewhat in their practice of marketing their catch, sometimes selling it in the native markets but often carrying it to their home ports, where its identity is lost by mixing it with the products of other localities.

In the following pages an endeavor has been made to present such statistical information as is available relating to the number of men and boats engaged and 
the value of the product. The transshipments between the various markets make it difficult, if not impossible, to state the value as a whole, and while the available figures, official and otherwise, have been used, the following must be regarded as an estimate:

Spain and France (estimated) Adriatic:

Istria and Dalmatia (estimated)

Gulf of Taranto (I902)

Eigean Sea, including Crete and sponges brought from the African coast and Lampedusa ( $190 \mathrm{r}$ ) r, 090,000

The Levant _...

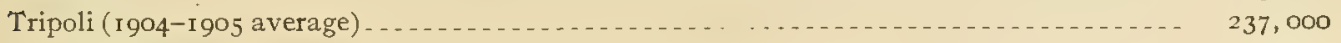

Tunis (r904)

Lampedusa, etc. (1904)

2, 039,000

This does not include the sponges sold at Benghazi nor the Egyptian catch, but as there are undoubtedly some duplicaticns, it may be assumed with some assurance that the annual product of the Mediterranean fisheries is valued at not far from $\$ 2,000,000$. The various fisheries, considered more in detail, are as follows:

\section{SPAIN AND FRANCE.}

For years sponges have been known to exist on the Spanish coast, but until recenily practically no attempt was made to develop a fishery. Explorations during the past few years have developed the existence of workable beds about the Balearic Islands and on the adjacent coasts of Catalonia and Valencia, particularly on the banks in the vicinity of the Columbretes Islands between Majorca and the Spanish Peninsula, and a small quantity of elephant-ear, zimocca, and honeycomb sponges have been taken there with scaphanders. The Spanish Government has taken steps to encourage the industry, and in I903 there were Io Greek diving vessels at work, but in 1904 these had dwindled to 2, and since then there have been none. Sponges are also found on the coast of France east of Marseilles, but they are scattered and few in number and have not been commercially exploited. Zimocca, elephant-ear, and honeycomb sponges are also found off the southern coast of Corsica and of recent years have been taken in small quantities by means of the diving machine.

ADRIATIC SEA.

The sponge beds of the Adriatic appear to have been always less prolific than those of many other parts of the Mediterranean, and they have suffered so severely from the fishery that they are now of comparatively little importance. 
They occur about the shores of the numerous islands of the Istrian and Dalmatian coasts south of Trieste in a depth of water not exceeding ro fathoms.

According to Faber, the toilet sponge comes from the vicinity of the islands of Incoronata and Zara Vecchia, the zimocca sponge is confined mostly to the coast of Istria, while the honeycomb sponge is generally distributed along the coast. The honeycomb or horse sponges of the Adriatic are rather brittle and inferior to those from other localities. The fishery employs from about i 50 to 200 men, who fish from small boats by means of harpoons and tongs during the good weather between March and October. The average catch per boat manned by two men is said by Faber to be about 300 to 400 pounds per year, the total yield being about 32,000 pounds, worth about $\$$ Io,ooo.

In I 902 about I I,OOO pounds of sponges of good quality, valued at from $\$ I .80$ to $\$ 2.30$ per pound, were taken in the Gulf of Taranto. This small fishery is carried on mainly by Italians, but in I 901 seven Greek boats, manned by 28 men, took about I,500 pounds of sponges, which were marketed in Greece at about $\$$ I.3O per pound.

\section{EGEAN SEA AND ASIA MINOR.}

The sponge beds about the Greek and Turkish islands of the Archipelago and along the coast of Asia Minor have been important from ancient times and have produced a race of bold and hardy fishermen, who have gradually extended their operations into all parts of the Mediterranean and within the last few years to the waters of the Gulf of Mexico and the Caribbean Sea.

The beds are scattered generally over the Figean, in the Gulf of Salonica, the Dardanelles, the Sea of Marmora, and the Bosphorus, but the principal centers of the fishery are in the Cyclades and Sporades, about the islands of Rhodes, Cos, Symi, Calymnos, Samos, Patmos, Hydra, Kharki, Kramihdi, Fggina, and Crete.

In these waters the sponges are taken by naked diving, the harpoon, the dredge, and the scaphander. The first two methods are the older, the last two having been adopted at a comparatively recent date. The fishery with the scaphander is now prohibited in the waters of Samos and Crete, and the advisability of expelling it from the waters of the Cyclades has been the subject of animated though futile debate in the Greek Parliament.

The sponge beds of this entire region are much less prolific than formerly, and much of the blame is ascribed to the diving machine. Many of the best sponges are now found in crevices, caves, and under overhanging rocks which abound along the shores of the islands of the Aigean, and being inaccessible to harpoons and dredges are taken only by the divers, especially those not using the diving dress. These sponges are generally denser and finer than those more directly exposed to the light. 
All varieties of Mediterranean sponges are found in these waters. The honeycomb sponge of the Cyclades is rather coarse and open in texture, but in Crete and many of the other islands it is of excellent quality. The other varieties are generally excellent, but not equal to the Syrian sponges, though those from the vicinity of Smyrna are coarse and open in texture and inferior in quality.

The sponge fishery is the most important and profitable of the fisheries of the Figean and it ordinarily employs between 4,000 and 5,000 men, accurate statistics being difficult to obtain, owing to the nomadic habits of many of the spongers who, as it has been stated, travel to all parts of the Mediterranean.

During the summer of 1903,318 vessels under the Greek flag alone employed 2,494 men in the sponge fisheries. There were I 34 vessels, using 158 diving outfits, upon which there were employed 599 divers and I,255 others. Thirty-six vessels with gangavas (dredges) employed I73, while I22 craft engaged in harpooning were manned by 443 persons. The operations of these vessels appear to have extended over a considerable part of the Mediterranean, and two crafts were used solely in the transportation of supplies to the African coast.

In 1900 sponge fishers of the Sporades produced about $\$ 900,000$ worth of sponges and in I9OI about $\$ 810,000$ worth, and in the same years there were exported from Piræus $\$$ I 7 I , 79I and $\$ 280,048$ worth, respectively, but undoubtedly a considerable proportion of these were taken on the African coast and the banks of Lampedusa.

The commander of the Greek hospital ship Kreta estimated that the Greek spongers took, in various parts of the Mediterranean in 1902, about 350 ,000 pounds of sponges, valued at about $\$ \$$ I, O0o,o0o. In I 902 the exports from Piræus were valued at $\$ 214,180$. In I 90 I toilet sponges from the Sporades averaged from $\$ 8$ to $\$ 13$ per pound and honeycomb sponges from $\$ 2.75$ to $\$ 4$. The United States consul at Smyrna writes that during more recent years the price was from $\$ 4.65$ to $\$ 15.60$ per pound.

The sponge fisheries of Crete are important, but the island has neither a local market nor native fishermen. The spongers are all Greeks from the Grecian and Turkish islands, who arrive on the grounds in the spring and in the fall return to their native places with their catch. From 150 to 200 vessels and boats, manned by from 800 to $\mathrm{I}, \mathrm{ooo}$ men, engage in the fishery, which produces an annual product valued at about $\$ 160$, 00o to $\$ 200,000$. This revenue is included in that before given for the Grecian and Turkish isles. The fishery is carried on by harpoons, naked divers, and dredges, the first paying an annual license fee of $\$ 18$ and the last two $\$ 46$ for each boat. The revenue of the government is from $\$ 4,000$ to $\$ 5$,ooo per year. The use of the scaphander is now prohibited, mainly for humanitarian reasons, but also on account of the depletion of the beds, which were formerly much more productive. 
THE LEVANT.

In this region the sponge beds surround the island of Cyprus and skirt the Syrian coast from the Gulf of Alexandretta to the vicinity of Latakia and from Jaffa to the Suez Canal. It is stated that about May, r907, a new bed was discovered, stretching off Port Said toward the north and northeast for a distance of about 50 miles.

The same methods are followed as in the Egean, and a very large proportion of the spongers come from that region. The scaphander was recently prohibited both at Cyprus and on the Syrian coast, though it is reported that several diving boats have been quite recently at work in the latter locality despite the prohibition. Cyprus has lately rescinded the prohibition of the diving machine, but the regulation excluding the gangava or dredge is still in force.

The American consul at Beirut estimated in 1902 that the annual export of Syrian sponges for several years preceding had averaged about $\$ 85$, ooo in value and that the product was gradually decreasing, owing to the depletion of the beds. According to Simmonds, the average yield about thirty years ago was from $\$ 100,000$ to $\$ I_{25}, 000$ per annum. From Cyprus the exports were valued at $\$ 10,425$ in 1898 and $\$ 28,835$ in I 899 , but it would appear that this may not represent the entire product of the island. The principal markets are Tripoli in Syria and Latakia. The sponges produced in both Cyprus and Syria are the very finest quality of cup and toilet sponges, although it is said that those on the south side of Cyprus are inferior. The very finest are sold by the piece and may bring $\$ 5$ o to $\$$ I Oo per pound, but the usual price is between $\$$ I 5 and $\$ 35$ for the fine levants.

EGYPT.

The sponge beds off the Egyptian coast extend from the vicinity of Alexandria to the Tripolitan frontier, and are practically continuous with the sponge grounds which reach along the Tripolitan coast to and beyond Benghazi. The sponges, especially those of Mandruka, are of excellent quality, but on the whole are not equal to those of the Eigean and the Syrian coast. The spongers are principally Greeks from the Archipelago, who were colonized at Marsa Matruh by the Egyptian government in I902. The fishery appears to be prosperous and is carried on without the use of the scaphander, which apparatus has been interdicted for hygienic and humanitarian reasons, vessels using it being subject to confiscation. The dredge is restricted to depths greater than 80 meters (262 feet), and is subject to an annual license impost of $\$ 50$ per boat, the tax for harpooning and naked diving being $\$ 25$ per boat. There has recently developed some difficulty in the enforcement of the regulations, owing apparently to the beds being beyond territorial jurisdiction and the spongers beyond the authority of the Egyptian government. 
TRIPOLI.

The sponge beds of Tripoli extend between the Gulf of Bomba and the region about Benghazi and from Misrata to the frontier of Tunis. In the western region some of the banks are as much as 20 miles from shore and produce a better quality of sponge than in the waters nearer the coast.

Most of the fishery is carried on during the warmer season from Apri1 to October, but a few of the more hardy crews of divers work at other times. The fisheries on the banks between Tunis and Misrata, which are known especially as the "Tripoli grounds," from Tripoli-in-Barbary, their headquarters and market place, appear to have been exploited first about 1889 . In I 890 they produced a value of $\$ 58,398$, and their average annual product during the next nine or ten years was valued at about $\$ 165,000$ per annum. The exports in 1904 were $\$ 337,750$; in $1905, \$ 226,196$; in $1906,232,565$; in $1907, \$ 213,300$, and in 1908 were estimated at $\$ 175,800$. In I 898 there were engaged in this fishery 53 scaphander vessels with crews of 963 men, and 25 dredges with 150 men. The former are mostly Greek, but there are a number of vessels flying the Turkish flag and manned by Greeks from the Sporades. The trawlers, or dredgers, are principally Italian. During the active fishery the Greek Government maintains at Tripoli a shore hospital and a hospital ship, to care for the divers and sailors meeting with accident or injured by the reckless use of the diving apparatus. Four methods of fishing are practiced; naked diving, harpooning or hooking, dredging, and diving with the scaphander. The latter method predominates, and of late years harpooning and dredging are said to be falling into disuse. The fishery appears to have reached its maximum development, despite efforts that have been made for its increase. The Turkish Government imposes a license tax upon the vessels, graduated from \$ 447 per annum for scaphanders to $\$$ I 8 for boats employed in harpooning. Boats engaged in naked diving are taxed about $\$ 45$ each, and trawlers pay about $\$_{\mathrm{I}_{3}}$ if measuring 5 tons or under and $\$ 26$ if above 5 tons.

The sponges from these grounds are darker in color and inferior to those from the Egean Sea and the Levant. The first quality of bath sponges, which comes from the rocky bottoms, formerly brought from $\$_{I} .50$ to $\$_{I} .90$ per pound and the second quality, from the grassy bottoms of the channels, from $\$$ I.I 5 to \$I.50 per pound. Recently prices appear to have appreciated, the American consul at Tripoli in Barbary stating in 1908 that sponges from rocky bottom sold for $\$ 2.73$ to $\$ 3.64$ per pound, those from shingle bottom for $\$ 2.05$ to $\$ 3.07$, and those from grassy areas for $\$$ I.9I to $\$ 2.39$. He states further that an average catch for a machine boat with I 2 to I 4 divers is $\$ 6,000$ to $\$ 7,000$ a season, and that a boat with 4 or 5 naked divers will average about $\$ \mathrm{~T}, 200$. About one-fourth of the product is marketed in Tripoli, the remainder being carried home by the foreign fishermen and mixed with inferior or medium grades coming from other localities. 
The sponges from the Bay of Bomba and neighboring parts of the Tripolitan coast, which are generally known in the markets as Benghazi sponges, are much superior to those above described and will sell for from two to four times the price of Tripoli goods. In I 908 bath sponges sold for $\$ 6.20$ per pound, toilet sponges for $\$ 8.22$, and cup sponges for $\$$ I $_{3} .65$. The bath or honeycomb sponge of Benghazi is hardly inferior to that of Mandruka and most of the better ones are sold as such. The annual product of this region is about $\$ 75,000$ to $\$ 90,000$.

All types of Mediterranean sponges are found on the coast of Tripoli, but zimoccas and honeycombs are more common, especially on the Tripoli grounds.

TUNIS.

The Tunisian sponge beds lie between Bibau and Sarsis near the Tripolitan frontier, about the island of Gherbis, in the Gulf of Gabes, in front of Sfax between Mahares and Mehedia, about the Kerkennah Isles, and along the coast in front of Monastir and Susa.

Sponges are taken on these coasts by wading, naked diving, harpooning, dredging, and diving with the scaphander. The seasons vary with the method. Naked diving and harpooning are carried on in general from October to January, at the time when the bottoms are cleaned of vegetation and the sponges can be plainly seen, but the use of the scaphander and the dredge is physically possible throughout the year.

Wading is practiced by natives only, especially those of Kerkennah and Gherbis; the harpoon is employed by natives, Sicilians, Maltese, and Greeks; the dredge is used by Sicilians and Greeks, while the latter alone employ the scaphander. The Tunisian government has recently interdicted the use of the scaphander during November and December and has restricted the number of licenses to be issued. In 1904-5 the maximum was 22 .

In 1904 the fishery gave employment to 1,368 vessels and boats, of which 522 were Italian, 79 Greek, and 767 Tunisian, upon which were employed I,688 Italians, 444 Greeks, and 2,299 natives, a total of 4,43I men. Gourret says that in $\mathrm{I} 896$, an average year, there were engaged in the fishery $\mathrm{I}, 089$ vessels, measuring $2,37 \mathrm{I}$ tons and manned by $3,20 \mathrm{I}$ men, in addition to which there were 169 persons taking sponges afoot (wading). In 1854 there were but 102 boats, and in I882, according to Henneque, 572 boats and vessels-Sicilian, Greek, and native.

Following is a table of the product for various periods since I854:

\begin{tabular}{|c|c|c|c|c|c|}
\hline Year. & Pounds. & Value. & Year. & Pounds. & Value. \\
\hline 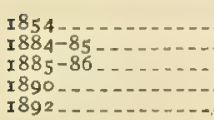 & $\begin{array}{r}26.400 \\
206.000 \\
197,000 \\
245,000 \\
200,000\end{array}$ & $\$ 12,000$ & $\begin{array}{l}1894 \ldots \ldots \\
189600 \\
1900 \ldots \\
1904 \ldots \ldots\end{array}$ & $\begin{array}{l}254,000 \\
222,000 \\
211,200 \\
234,000\end{array}$ & $\begin{array}{r}\$ 224.000 \\
434,900\end{array}$ \\
\hline
\end{tabular}


Judging from the statistics alone, the fishery seems to have been well maintained during the past twenty years.

The sponges of Tunis are inferior to those of Tripoli and average from to to 20 per cent less in price for corresponding kinds. Those taken by the gangava or dredge bring a lower price than the product of either the harpoon or scaphander, probably on account of their miscellaneous character as to both size and quality. Many of the native spongers sell their catch in its natural or uncleaned condition (pêche noire), but the foreign fishermen all clean their product (pêche blanche) before selling it.

The Tunisian Government has followed a vacillating policy in regard to licenses for the fishery, especially as to the scaphander; but in 1903 the annual fees were fixed at $\$ 20$ for harpoons, $\$ 75$ for dredges, and $\$ 200$ for scaphanders. For the "pêche noire" the tax is $\$ 8$ per boat, all sponges to be landed and sold in the uncured state.

Sfax and Gherbis are the principal markets, whence a large part of the product is shipped to Marseilles. Owing to the imposition of an import duty in France there is a growing tendency to ship to London.

\section{LAMPEDUSA AND THE SICILIAN SEA.}

The sponge fishery in these waters is carried on from March until about the middle of November, principally on the banks stretching south and southwest from Lampedusa almost to the coasts of Tripoli and Tunis, but also to some extent north of Pantellaria and off the west coast of Sicily. The fishery is almost solely in the hands of Italians and Greeks, although a few Turkish and Tripolitan vessels are occasionally engaged in it. In 1904 there were 63 Italian vessels of 1,302 tons carrying 309 men and 37 Greek vessels of a total tonnage of 716 and carrying 406 men. The vessels range between ro and 40 tons.

Three methods are employed in the fishery-harpooning or hooking, dredging, and diving with the scaphander. The native fishermen use the first two methods solely, while about half of the Greeks employ the diving dress. The Italian fishermen are practically all Sicilians, though a few come from Naples.

In 1904 the product was about 81,000 pounds, valued at $\$ 123,000$, as compared with 98 ,ooo pounds, valued at $\$$ I 50,000 , in 1903 and 68 , 000 pounds, valued at $\$ 85,000$, in 1902 . Both the product and the number of persons engaged in the fishery have decreased since 1899 .

The Italian spongers sell most of their catch at Lampedusd, whence it is shipped to Palermo, Leghorn. Milan, Ancona, Venice, Trieste, Paris, Marseilles, and Barcelona. Those taken by the Greek divers are carried to Piræus, where those of the best grade, which come from the bank of Mezogiorno, bring about 20 per cent more than in Lampedusa. In I904 the sponges taken with the gan- 
gava brought about $\$ 1.80$, and those caught by the divers from $\$ 1.80$ to $\$ 2.90$ per pound, the product of the scaphander being superior in quality as well as larger.

The sponges taken on the banks of Lampedusa and the -Sicilian Sea are Turkey cup and toilet, elephant ear, zimocca, and honeycomb. They vary in quality on the different beds.

\section{ALGERIA AND MOROCCO.}

There are sponges on the coast of Algeria, but beds extensive and rich enough to warrant a fishery are unknown. The elephant ear was recorded from Bona many years ago, and a toilet sponge similar to that of the Adriatic has been found at I,aCalle, Philippeville, and other places on the coast. Within a few years the Spaniards have explored the coast of Morocco and have found beds capable of commercial development.

\section{METHODS OF THE FISHERIES.}

The methods followed in fishing for sponges in the Mediterranean, though differing somewhat in details, are essentially the same as those employed on the coast of Florida, with the addition of nude diving (which though occasionally practiced on the American coasts has never been of any importance commercially) and dredging.

Wading.-This was probably the primitive method of sponging in the Mediterranean, as it was in Florida, but with the extermination of the sponges in shoal water it has long disappeared as a factor in the fishery, excepting on the coast of Tunis. The natives of Gherbis and the Kerkennahs take a few sponges in this manner, wading in the water to their necks when the sea is smooth, detaching them with their toes and kicking them within reach of the hands, and occasionally diving into the holes where the water is slightly deeper. The sponges taken by this method are inferior.

Nude diving. - This is another ancient method and a logical sequence of the preceding. It is practiced principally by the Greeks of the Archipelago, the Syrians, and natives of the Tripolitan and Tunisian littorals. It is said that the most skilled naked or "common" divers are from the islands of Calymnos and Symi, and that some of them can descend to the enormous depth of 240 to 250 feet. If this be true it is far in excess of the depths reached by ordinary divers, which usually do not exceed 50 feet. They ordinarily remain under water about two minutes, resting about thirty minutes between dives, but experts sometimes stay down four minutes, and it is stated on good authority that two extraordinary divers of Calymnos remained under water over five minutes, though the depth is not stated.

To aid their descent the divers hold in their hands a flat stone (scandli) attached to a cord, the other end of which is held by a man in the boat. When 
the bottom is reached the stone is dropper, the diver retaining hold of the cord to prevent floating, while he gathers the sponges within reach, which are deposited in a net bag attached to his wraist. His desire to come up is signaled by jerking on the cord.

The nude divers are not attacked by the serious maladies to which the machine divers are subject, and despite the arduousness of their calling are able to follow it for years, but owing to the brevity of their stay beneath the water and the length of the intervening rests their actual working time is short.

This method of sponging is followed to best advantage on uneven bottom too rough for the dredge, where the sponges are in crevices or under overhanging ledges which make them invisible to the harpooners or where the rocks are so sharp as to make the use of the scaphander dangerous, owing to the liability of injury to the suit and hose. Most of the finest "cave" sponges of the Figean are taken by this means.

Nude diving is carried on from small boats, the crews of which are generally paid wages, while the diver works on shares. On the African coast this fishery is carried on during the fall and early winter, when the bottom is comparatively free from marine vegetation, but in the Agean and the Levant it is conducted during the warmer months of the year.

Harpooning.-This, historically the third method of sponging, has been used in the Mediterranean for many years and is still employed on practically all of the sponging grounds where the water is not too deep. It is practically the same in its general features as the hooking on the Florida coast, and the conditions of wind and weather necessary for its success are the same. The instrument employed is essentially a trident, though it may have other than three barbed points or tines. The Tunisian fouchga has two barbed points, the Sicilian fuscina, fuscia, or fiocino has three points, the Greek kamaki has four, while the Dalmatians use a five-pointed instrument. These all differ from the hooks of Florida and the Bahamas in having the tines straight instead of recurved.

The water telescope, practically similar to that used in Florida and the Bahamas, is now generally employed in all parts of the Mediterranean, but it was not used on the African coast until introduced by the Greeks about i 875 .

The boats employed are various, each nationality having its preference, those of the Sicilians resembling New England dories; but they are all small, and are manned by two or sometimes three men, one of whom is the harpooner. The boats used by the Greek harpooners are similar in shape to the diving boats elsewhere described. The harpooner stands in a small circular hatch forward and, with a cushion placed beneath his chest, leans over the bow to scan the bottom through his water glass. The nomadic Greeks and Sicilians use large living and deposit boats, while the native spongers of the various regions have 
smaller, less seaworthy vessels, or dispense with them entirely when working near home. The working boats, corresponding to the dingeys of the Florida coast, are propelled usually by one, occasionally by two, pairs of oars, and are not sculled with a single oar as in our own waters. When a sponge is sighted the harpoon is driven into it, preferably on the side near the root, and it is detached by a double motion of rotation and rocking.

This fishery is practicable in deeper waters than those in which hooking is carried on in Florida. Depths of even 70 to 80 feet are reached, and off Benghazi sponges are harpooned in as much as 90 feet. In fishing in such deep water three persons are assigned to a boat, the third usually a boy handing the harpoons to the harpooner and assisting in attaching and detaching the additional shafts.

The poles are about 20 feet long, and to the top of each is lashed a short stick, about 6 or 8 inches long, the end of the pole being slightly cut away to create a space between it and the stick. Into this gap the end of the next harpoon is thrust and held in place by a ring, just above the iron, which is slipped over the stick. A third, or as many harpoons as are necessary, are added to reach the desired depth. After the sponge is impaled and torn loose from the bottom the poles are successively detached as they are brought up. The sponges are less firmly attached to the bottom than are those of Florida.

Owing to the rents likely to be made by the harpoon, the finer grades of sponges are less valuable when taken by this method than when procured by diving, and are known in the markets as "harpoonées," as distinguished from "plongées." On the Tunisian coast there appears to be but little difference between the two in price. In Dalmatia tongs are employed, one leg of which is attached to a pole and the other operated by a cord.

Dredging or trawling. - The dredge or trawl (Greek gangava, Italian gagova or cava, French drague), shown in text figures 2 to 4 , is of special type and large size, and has been used for many years by Greeks in the Levant and by Greeks, Sicilians, Neapolitans, and Maltese on the coasts of Africa and the banks of Lampedusa. It consists, essentially, of a rectangular frame from i 5 to 40 feet long and from 20 to 30 inches high, to which is attached a bag about 6 to Io feet deep, made of large-mesh webbing of light rope (fig. 2, p. 487).

That part of the frame which scrapes the bottom is a round iron bar about $21 / 2$ to 3 inches in diameter, the ends being bent at right angles for a distance equal to the desired height of the frame and connected by a stout wooden bar to form the top. Frequently the ends of the frame are short wooden bars fitted into sockets in the upturned ends of the iron bar (fig. 3, p. 488).

In the larger frames the parallel iron and wooden bars forming the bottom and the top of the frame, respectively, are connected and stiffened by one or two transverse struts (fig. +, p. 488), but in the smaller dredges these are omitted. 
The bridle is composed of a rope running from the middle of the wooden top bar and two, three, or four chains connected near the ends and at one or two intermediate places on the bottom bar, all being united in an eye or ring to which the towrope is attached. The several parts of the bridle are of such comparative length that the frame stands upright when towing. The net bag is laced to the wooden top bar and to rings welded to the iron part of the frame. The tow rope or cable varies in length from 300 to 600 feet, and passing through a chuck or snatch block near the bow is led aft to a hand wind-

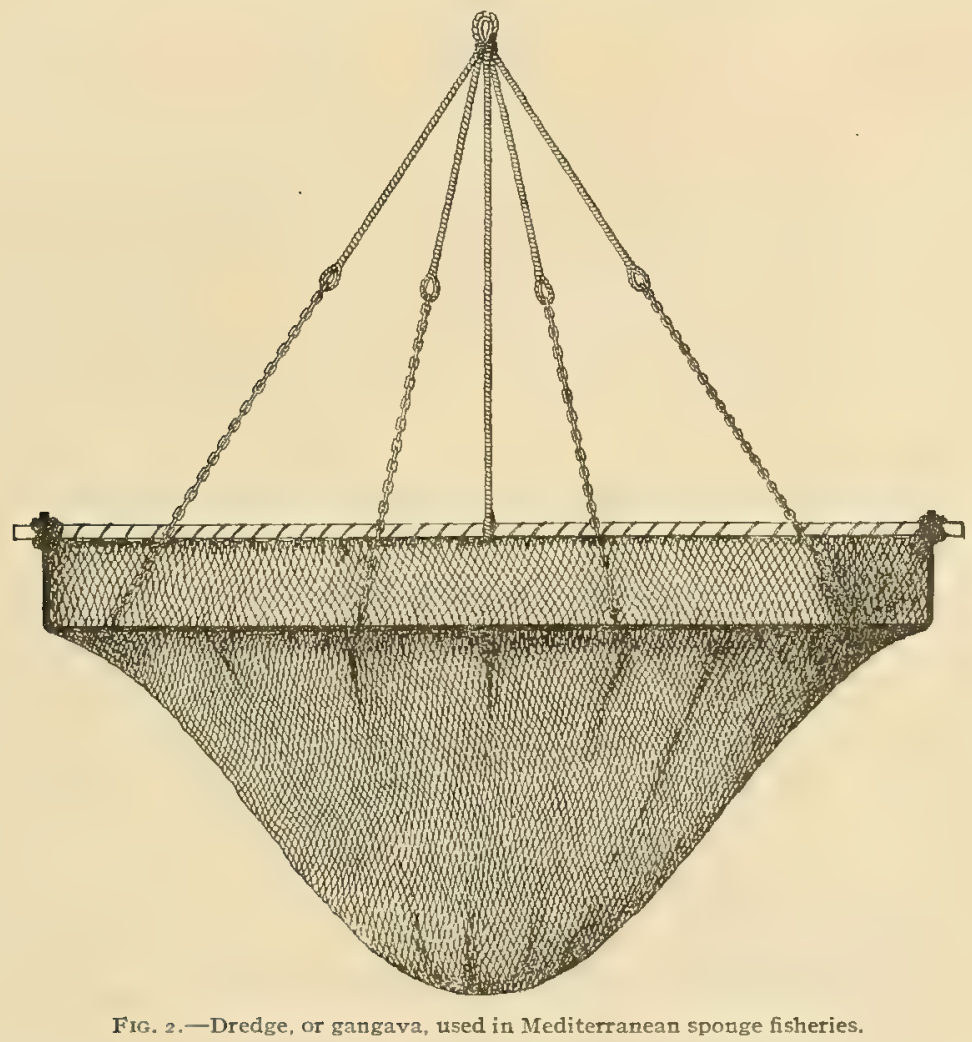

lass. A guy line bent to the cable with a rolling hitch at some distance from the vessel is led directly to a cleat or bit near the stern, and is used in controlling the drift of the vessel. A similar line is carried under the jibboom and attached to the opposite side, to be used when the vessel comes about.

The method of using the dredge is essentially as follows: By means of masthead tackles or davit tackles attached to the wooden bar of the frame it is lowered bag first until the frame reaches the level of the rail. The towline is then bent to the bridle cringle and carried through a snatch block forward. The tackles are cast loose and the net lowered by slowly paying out the tow line 
until the bottom is reached, when paying out ceases for a moment to allow the bag to straighten out without fouling the frame or bridles. The weight of the chains and the lower part of the frame and the buoyancy of the wooden upper bar makes it easy to land the apparatus right side up. The towline is then paid out with a scope commensurate with the strength of the wind, less being required in light and more in strong breezes, and the guy lines are bent

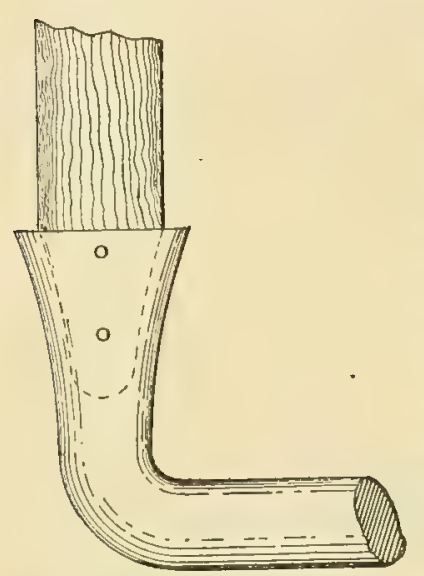

FIG. 3.-Section of dredge, frame showing bend of iron bar at ends. on at such distance from the ship as to give proper facility in handling.

The apparatus is always paid out on the windward side, the vessel drifting to leeward with comparatively slight headway, so as to drag the dredge at a speed of about one mile per hour. The guy line is used to govern the baat's position with respect to the dredge and the wind so as to secure the proper direction and speed of drift. Slacking the line puts the boat closer to the wind, decreasing both speed and headway, while hauling it in puts her off the wind, thereby increasing both headway and drift.

Should the direction of drift carry the dredge off the edge of the sponge bed, the weather guy line is slacked, the vessel comes into the wind, the lee guy is hauled in, the towline is passed under the bowsprit and made fast on the other bow, while the vessel pays off on the opposite tack across the bed.

When the dredge is full, the fact is indicated by the heavy drag of the apparatus. The headsails are then lowered and the guy line is paid out until the vessel is head to the wind. The towline is passed to a snatch block forward and is hove in until the bridles come home to the block. Two rather long flying bridle lines, not shown in the drawing, are then hooked to masthead tackles, or usually to a pair of davits, and are hove in by small hand windlasses until the iron bar is
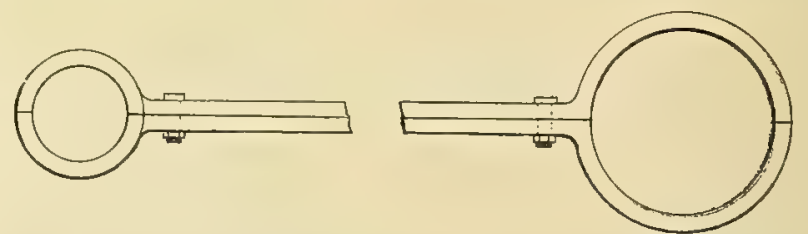
brought level with the rail, Fig- 4-- Transverse struts sometimes used between bars of dredge frame. where it is secured by a couple

of chain stops. The contents of the bag are then overhauled, the rubbish thrown overboard, and the sponges on deck. Three men can handle the vessel and dredge, but as the work is carried on day and night the crew generally consists of 5 or 6 .

This apparatus can be employed on smooth bottom only, as the frame is liable to foul and the net to be torn on rough rocks, but it can be used at all seasons of the year and in all ordinary weather. It is much complained of for its destruc- 
tiveness, the charge being made, apparently with justice, that it tears loose or crushes all sponges in its path, both large and small, and that not only is a considerable portion of the catch inferior on account of the small size, but that many sponges are torn loose and not brought up at all, being left to die on the bottom or to become rollers. In some localities the gangava is prohibited in depths less than a prescribed minimum. In Egypt the limit is fixed at 80 meters (262 feet), and in Cyprus the instrument is entirely prohibited. It is used principally on the African coast and on the banks of Lampedusa.

There are probably between 400 and 500 dredges or gangavas employed in the sponge fisheries of the Mediterranean, of which the great majority come from the Sporades and Cyclades.

Machine diving.-This method of diving and the apparatus employed is sufficiently described in that part of this paper treating of the Florida fisheries. The scaphander was introduced into the Eigean and the Levant about I866, and at once came into such general use among the Greeks that ten years later about I I O machines were in active service. In $\mathrm{I} 907$ it was reported that there were from roo to I 20 diving machines for sponge fishing owned in Greece alone. In 1903 there were 158 diving outfits employed in sponging under the Greek flag, the reduction in 1907 being probably due, at least in part, to the export of apparatus to the United States for use in Florida.

From the time of its introduction the diving dress has met with active and sometimes violent opposition from the spongers using the older methods, who charged it with being destructive to the sponge beds. Recently it has been opposed on hygienic grounds, and, mainly through the efforts of Mr. Charles Flegel, since 1892 its use has been prohibited in Austria-Hungary, Egypt, Crete, and Samos. Turkey also passed prohibitive laws, but they were not enforced and have been repealed, and the interdiction formerly existing in Cyprus has been removed. Italy and Greece have placed restrictions on the depth to which the divers may go, and both have vessels to enforce the law, which, however, is more or less generally ignored. The Greek regulations prohibit all diving at greater depths than $x_{27} 7$ feet, and at least until recently regulated the period for which the diver could remain submerged at various depths. During the sponging season the Greek Government maintains a hospital and hospital ship on the African coast to provide medical attention and succor to the divers.

Some divers are injured or killed by accidents to the diving dress or hose, but the chief danger to which they are exposed is caisson disease, which is a frequent consequence of working in depths of over 60 feet. This malady is caused by the absorption of gases from the compressed air and their release as bubbles in the blood vessels and tissues upon decompression, especially if the latter be rapid, as in the quick ascent of a diver from the bottom. In caisson 
work rapid decompression is guarded against by gradual transition from higher to lower compressions in the air locks, or in carefully regulated diving with the scaphander by slow ascents, but in sponge diving these precautions are ignored, with the result that many of the divers become paralyzed and a considerable number of them are killed. Flegel states that the average yearly mortality among the Mediterranean divers reaches the almost incredible proportion of nearly 20 per cent, and the cases of more or less serious illness about 25 per cent. He states, further, that during thirty-nine years upward of 5, roo sponge divers were killed by their work and 2, I oo were so paralyzed as to be incapacitated.

That the results of sponge diving are so serious is not surprising in view of the practices obtaining. I am informed by various authorities that the machine divers in the Mediterranean go to a depth of 250 feet, remaining on the bottom three or four minutes at each descent. Boats working in these depths carry i 2 or $\dot{i}_{3}$ divers, each of whom has a rest of about two hours between plunges. Though the pressures are so great that the heavy woolen stockings worn by the divers are pressed deeply into the flesh, no measures are taken to ascend gradually, the claim being made that the more quickly the person is removed the less the liability to injury. Sponge divers have informed me that serious cases of "bends" occur more frequentiy in depths less than 25 fathoms than in those greater, owing to the shorter time to which the diver is subjected to the pressure in the latter case.

On the other hand the highest scientific authorities on diving place the safe limit for physically sound men at $\mathrm{I}_{50}$ feet, and they all prescribe a slow ascent and a gradual release from pressure as an essential element of safety. In caisson operations, where the conditions under which the men are working are essentially the same as those in a diving dress, the compulsory use of air locks for gradually reducing the pressure on workers making the exit has been found absolutely necessary to preserve the health of the workmen. It appears that the incentive to deep diving is imposed largely by the financial conditions under which the fishery is conducted. The masters of the vessels, having little capital, are obliged to borrow at rates as high as 25 per cent, and feel obliged to force their divers in order to make their ventures pay.

In many parts of the Mediterranean the sponges grow on bottoms covered with vegetation, the location being often indicated by a mere hiatus in the tops of the growth. In working on such bottom the diver lies almost horizontally above the vegetation, looking for the telltale spots and locating the sponges by feeling with his hands.

About the islands of the Ægean many sponges are attached to the faces of submarine cliffs 50 or 60 feet high, and to reach them the diver floats himself by regulating the air pressure in his suit and propels himself from place to place by a swimming motion of the hands. 
The scaphander fishery is mainly in the hands of Greeks from both the Grecian and Turkish islands, and there were recently between 250 and 300 diving outfits in use in the sponge fisheries of the Mediterranean.

Cleaning and curing.-The native fishermen of Tunis sell their product in the natural state, but all of the other spongers of the Mediterranean cure their catch before selling it. The process of curing is essentially that followed by the Greek divers in Florida which has already been described. The sponges sold by weight are loaded with sand, marble dust, and other materials. They are packed under foot in cylindrical bales weighing from 40 to 75 pounds, or in boxes. A considerable proportion of the Mediterranean sponges are bleached before entering the final markets, the process being essentially that employed in the United States and elsewhere described.

\section{VARIOUS MINOR LOCALITIES.}

Sponges of some economic value are found at various places which have not yet developed fisheries of commercial importance. In other localities sponges closely allied to economic species or zoologically identical with them have been recorded by naturalists, though but little is known of their abundance, accessibility, and characteristics as measured by commercial standards. Certain of these places geographically adjacent to the important sponge fisheries of North American and the Mediterranean have been discussed, but the isolated localities can be considered most conveniently in a separate chapter. Certain of them are quite likely to develop, eventually, fisheries of more or less importance, especially with the growth of a demand for sponges incident to the extension of modern civilization and manufactures.

\section{PHILIPPINE ISLANDS.}

When this archipelago has been more thoroughly explored and its marine resources are more generally known it is probable that it will support a sponge fishery of some importance. The recent work of the Bureau of Fisheries steamer Albatross, not yet concluded, has brought to light several sponges of commercial utility, though of rather poor quality.

The Tawi-tawi group appears to be particularly rich in horny sponges, some of which are of value commercially, and the Albatross obtained specimens at Siminor, Tataan, and other localities. Small grass sponges were found in extraordinary abundance on the tide flats of Tataan Island, attached to the coralline and shelly bottom in a depth of I to I I/2 feet at low water. Several other kinds of possible value are reported from the same locality.

Similar sponges are found at Siassi in the Tapul group and several Americans have recently gone into the business of gathering them for the market. Inexperience in curing and packing lessened the value of the product, but it is under- 
stood that instructions given by the Albatross party have resulted in improvement in this respect.

About the island of Sitanki or Sibutu there are considerable beds of sponges resembling somewhat the toilet sponge of the Mediterranean, though with the upper surface more fibrous and with numerous closely ranged pores. The sponge is very soft, but much weaker in fiber than its Mediterranean congener. Thirty or forty thousand of these have been marketed in Singapore and shipped to New. York and London, where they brought a low price.

On the south side of Jolo the Albatross obtained a single beach-worn specimen closely resembling the reef sponge of North American waters. From the north side of the same island there was collected, in a depth of 20 fathoms, a specimen resembling the elephant-ear sponge, very strong but harsh and rather incompressible. The texture is closer and more dense than in the Mediterranean sponge and the primary fibers of the skeleton are so heavily laden with sand granules as to render it of but little commercial value. It is possible that superior qualities may be found in other localities. The specimen collected is about 15 inches in diameter, almost flat, with several flaps or lamellæ on the upper surface, and was attached by a short stalk or peduncle.

Small sponges said to resemble the Key grass of Florida are sold in the shops of Cebú and are reported to come from nearby reefs. Others of excellent quality resembling wool and yellow sponges are sold in native shops in various places but are believed to be imported. I have been shown a specimen, said to be indigenous, which very closely resembled the Bahama sheepswool. It had apparently been in use for bath purposes and I am convinced that it was exotic. Another specimen from an unknown locality was of excellent shape and quality, somewhat resembling the honeycomb sponge of the Mediterranean but differing from it sufficiently to remove suspicion that it was not of native origin. It was soft, strong, firm, and elastic, rather flat and attached by a narrow base. If it can be obtained in quantities, it should prove of considerable commercial value.

\section{AUSTRALIA AND NEW ZEALAND.}

The sponge fauna of Australia is exceedingly rich, and according to Lendenfeld the zoological species which include the elephant ear, honeycomb, zimocca, glove, and reef sponges are found on its coasts, in addition to several others which he regards as of possible commercial value. The rather poor specimens of Australian sponges which I have examined, comprising Io or I 5 species of supposed commercial value, were nearly all of inferior quality, open in texture, irregular, hard, and harsh. The specimens had the appearance of being beach worn, and the defects of some of them were due in part to imperfect curing. One or two kinds could probably find a limited market at a low price. Attempts have recently been made to find a market for these sponges with a 
view to establishing a fishery, but it is understood that the results have not been encouraging. Honeycomb and reef sponges are reported to occur in New Zealand.

\section{OTHER PACIFIC OCEAN LOCALITIES.}

The horny sponges of the Pacific islands are known practically from the Challenger collections only, those of the various expeditions of the Albatross not having been studied.

In the Sandwich Islands there occurs a sponge which somewhat resembles the sheepswool in appearance, but the single specimen upon which the report is based was hard, very weak of texture, and of little, if any, commercial value. A reef sponge from the Fiji. Islands and a grass sponge from the Gilberts, both of doubtful value, practically complete the record for this region, although the Carolines are stated to produce a soft, fine sponge, probably not unlike the Sitanki sponges of the Philippines.

\section{INDIAN OCEAN.}

I have recently received inquiries in regard to a toilet sponge from the coast of Madagascar. It is stated to "look like the Mandruka toilet sponge," but to have a poor texture and to be lacking in durability. This is possibly the sponge which Cotte says is taken at the southern end of the island about Cape St. Marie. The American consul at Tamatave in response to inquiries reports that sponges occur on the west of the island from Cape St. Marie to Ambohibe, a distance of 340 miles. About I902 5 Greek divers were employed by 2 merchants and in 1907 some Ceylonese were employed by another concessionaire, but both experiments proved failures and excepting a few sponges taken by natives there is at present no fishery. The price received by native fishermen is about $\$$ I.I5 per hundred pieces, the sponges being very badly cured. None were exported in 1908.

Lendenfeld records several varieties of the common toilet sponge, the velvet, and several other species of horny sponges from Mauritius, but nothing is known of their economic value.

Sponges also occur in the Seychelles, and the government of those islands has recently taken steps to determine their commercial value.

In Ceylon a variety of the toilet sponge is found in abundance, and Hornell believes it to be of commercial value. Euspongia irregularis pertusa, which includes the yellow sponge of the Gulf of Mexico, is also recorded from the island, but nothing is known as to its commercial characteristics and value.

\section{MID-ATLANTIC OCEAN.}

Weil states that there are beds of excellent sponges lying in deep water about the Cape Verde Islands and the Azores, and that in quality and general characteristics they are intermediate between those of the Mediterranean and 
western Atlantic. He believes that in those places a profitable fishery merely awaits the time when the exhaustion of the older fisheries will force their exploitation.

I have been informed by a Greek of wide experience on both sides of the Atlantic that in the shallow waters about the Canary Islands there is a sponge closely resembling the coarser qualities of the yellow sponge, though the shape is flatter.

Several sponges are reported from the Madeiras and the Bermudas, those of the latter islands resembling those of the North American coast and including the grass, sheepswool, and possibly the velvet. The velvet sponge is also recorded from Fernando de Noronha, off the Brazilian coast, indicating the probable extension of the American commercial sponges along the mainland south of the equator.

\section{CONDITIONS AND EFFECTS OF THE SPONGE FISHERIES.}

\section{DEPLETION OF THE BEDS.}

Wherever the sponge fisheries have been prosecuted with vigor for a long period, there has resulted a more or less definite depletion of the beds, or a wellgrounded fear of the approach of that condition. The commercial sponges can never be actually exterminated by the agency of man. It is an impossibility to denude the grounds so completely as to leave none for reproduction, and, moreover, as soon as the beds become so depleted as to reduce the earnings of the spongers to a bare living wage, the economic result is a reduction in the number of fishers and the establishment of an approximate equilibrium between productiveness and catch. The point at which this equilibrium is established will vary with economic conditions, becoming lower with an increase in the value of the product and higher with an increase in the cost of living of the fishermen. More men, gathering in the aggregate a somewhat larger quantity of sponges, though the catch of each individual may be less, can be supported when the price is high than when it is low, and this results in increasing the fishery, in a further reduction in the productiveness of the bers, in profits, and eventually in the number of fishermen, the equilibrium being again established on a somewhat lower plane of productiveness. Thus, while the sponges are never actually exterminated there results an approximate commercial extermination, never quite complete for the reason that were the fishery entirely abandoned the beds would soon recuperate and again become commercially productive.

This is well illustrated in a number of cases. In the Adriatic, sponges were formerly much more abundant, but the fishery has been nearly stationary for a number of years. In the E⿱Egean and on the Syrian coast there is said to have been a material decrease during the past thirty years, but the conditions of the 
fishery are such that it is difficult to obtain statistics which will show the actual product of the beds in those waters.

On the African coast the yield of the beds during the past fifteen or twenty years has been fairly maintained, though most writers on the subject have expressed the opinion that the productiveness of the beds is waning, and that the average size of the sponges is growing smaller. Such statistics as I have been able to obtain show a rather remarkable uniformity in the total catch. In the fishery tributary to the Benghazi market the only material variation in the catch between $\mathrm{I} 889$ and $\mathrm{I} 895$ can be traced to a difference in the intensity of the fishery, especially in the number of scaphanders employed. In Tunis during the twenty years between I 885 and I 904 the maximum yield has exceeded the minimum by about 25 per cent, and the catch of 1904 was greater than for any year previously recorded, excepting I 890 and I894. The average catch of three years prior to 1892 was 2 I 6 , ooo pounds and for five years since that date 224,000 pounds. In this connection it must be noted, however, that between 1890 and 1892 , principally in the latter year, there was a rapid increase in the number of fishermen from about 3,000 to about 4,500 with a corresponding increase in the number of boats employed. In other words, if the statistics be reliable, an increase of 4 per cent in the average yield of the fishery has been produced by an increase of about 50 per cent in the number of fishermen. This, possibly, may be accounted for to some extent by changes in regulations or methods of which I am ignorant, but the facts substantiate the statement that the dealers of Sfax and the spongers themselves are of the opinion that the fishery is being depleted, as indicated by the smaller catch per man employed and the increasing proportion of small sponges.

The total product of the banks of Lampedusa has decreased materially since $1888-1899$, when the fishery reached a maximum in both yield and intensity. Considered by five-year periods, the available statistics appear to indicate some depletion of the beds during recent years. During five years from I 890 to 1894 , inclusive, the average catch per sponger was about $\mathrm{r} 5 \mathrm{I}$ pounds, the average of five years from i 895 to i 899 , inclusive, was the same, while the average of the four years from I 90 I to I 904 , inclusive, was but I 20 pounds, a decrease of 20 per cent. Owing to the fluctuating proportions of scaphanders and dredges from year to year and other variations in the fishery, it may be that this decrease has no great significance, but those familiar with the beds are of the opinion that their productiveness has decreased. It is noteworthy also that the smallest catches made since 1889 were in the years immediately following the intense fisheries between 1895 and I900, when the largest number of men and boats were employed and the beds most thoroughly scoured. In the Mediterranean the dredge and the scaphander are both blamed for the depletion of the beds, the former because it tears everything from the bottom and the latter because 
of the number of small sponges taken. The harpoon and naked diving are regarded as harmless, and it is generally held that the beds could not be seriously injured by those methods alone.

On the western side of the Atlantic the case is different. In Cuba and the Bahamas, and until recentiy in the United States, the diving machine has not been used and the dredge is unknown. Hooks, the equivalent of the Mediterranean harpoon, were the only implements employed, yet the complaints of waning productiveness of the sponge grounds are quite as loud and, in some cases at least, as well grounded.

The earlier statistics of the Florida fishery are nearly valueless for the determination of the productiveness of the beds. The sponges are bought by bunches which vary in weight with the size and character of the sponges and the manner in which they are strung, and the only comparative weights or quantities which are available are those of the packed goods. Unfortunately these weights are not those of the pure sponges but of sponges plus salt, sand, glucose, and other materials used in loading. Were this loading uniform the statistics would still be of some value for the purpose of the present inquiry, but the amount of foreign matter introduced has gradually increased since the practice was recommenced, about 1895 , after an interval of comparatively honest packing, until in 1903-4 I found it to range between roo and 150 per cent of the true weight of the sponges. At that time, and until the heavy influx of sponges from diving operations, practically all sheepswool sponges and some of the cheaper grades were heavily loaded, and even much of the small quantity sold as "pure" was more or less "doped" with salt, glucose, glycerin, and a little litharge. Since 1903 the statistical weight of the catch has been based upon an assumed approximate average weight of the bunches and the result is probably more accurate.

Considering the total yield of both Bay and Key grounds, the average catch of sheepswool sponges between 1895 and I899, inclusive, was I 73,043 pounds, while between 1900 and 1904 , inclusive, it was 186,155 pounds. In the latter period, however, there were two years, I9OI and I903, when clear water on certain grounds rarely fished gave the spongers access to practically virgin bottom. It should be stated, however, that in the latter part of this term the number of men and vessels employed exhibited some decrease.

In the period from 1905 to 1908 , inclusive, there occurred a great increase in the production, the average product of sheepswool sponges being 313,697 potnds. This was due to the introduction of diving.

Considering the production in its relation to effort expended in the fishery, we find that each man engaged in hooking from 1900 to 1904 , inclusive, produced an average of 100 pounds of sheepswool sponges per year as compared with an average of $8 \mathrm{I}$ pounds for the years 1905 to 1908 , inclusive. The 
average production per diving boat per month of actual operation, as nearly as can be ascertained, has been 385 pounds in 1905,437 pounds in 1906, 338 pounds in 1907 , and 206 pounds in 1908 . The latter part of 1907 and the entire spring of 1908 was characterized by boisterous weather, and part of the decrease may be due to these conditions.

So far as we can judge from the statistics, however, and making due allowance for the uncertainties of the fishery, there appears to have been a considerable decrease in the productiveness of the beds, especially in the Gulf of Mexico, since $\mathrm{r} 900$, a statement which is strongly supported by the observations of those engaged in the fishery.

\section{HOOKING AND HARPOONING.}

Hooking and harpooning are essentially the same and are limited by the same conditions. They can be carried on only when the weather is moderate and the water clear, and as the latter essential may occur on some beds only at intervals of several years, as, for instance, on the New grounds off Cape Sable and in the deeper water on the Bay grounds, there is imposed on these methods of fishery certain natural and irrefrangible close seasons which operate to effectually protect certain beds by restraining the fishery for sufficient periods to permit of recuperation. In most places, however, clear water is the rule rather than the rare exception; and in such cases hooking, while temporarily inhibited, may be carried on for a greater or less part of each year. When this is the case the effects on the beds are dependent upon the intensity of the fishery and the degree to which the fishers rob the grounds of young sponges. As a rule, wherever the beds are sufficiently productive to make it profitable they are worked beyond reasonable limits until more or less gradually the yield is reduced below the economic minimum and most of the spongers withdraw to other fields, leaving, however, enough of their less enterprising fellows to prevent the possibility of effective recuperation. This has been the case on the Key grounds of Florida, where the fishery continues to produce a small crop, though abandoned as unprofitable by most of the vessels and some of the boats. The New grounds, where the water is found clear only at intervals of several years, still produce sponges under favorable conditions, while several other places-for instance, the vicinity of Bamboo Key, which were almost abandoned for a while-have again become moderately productive.

In connection with the hook fishery there are two factors which assist in the recuperation of the beds. One is the presence of sponges in adjoining waters too deep to be reached with the hooks, and the other is the retention on the beds actually fished of sponges which are out of sight from the surface. This is more fully discussed in connection with diving. Another factor assisting in the recuperation of the beds reserved to hookers is the regenerative growth of fragments 
remaining attached to the bottom after the main portion of the sponge is torn loose. It often happens that the hooks are inserted above the base, and more or less of the root is left to grow into a new sponge. On overworked beds the spongers frequently find apparently large sponges which are so flat that the hooks can not be inserted at all, and a bed which has been fished continuously for a series of years produces more flat sponges than when first discovered. It is probably because the beds are only worked at intervals of several years that the New ground sponges have a greater height than those from other Key grounds, and the sponges now being taken from the rested Bamboo Key grounds are higher than those formerly obtained. It is not at all unlikely that this regeneration of attached "roots" is a more important factor in the rejuvenation of the beds than is generally supposed.

The greatest abuse connected with hooking is the capture of small sponges, though the proportion of those below the legal limit of 4 inches is smaller than in the catch of the divers. This abuse is always greater on partially depleted grounds, which are less able to stand the drain, than on newer and more productive beds. A gradual reduction of the average size of the individual sponges taken is always a serious symptom of depletion already accomplished and a potent cause of greater depletion to come.

NUDE DIVING.

Nude diving is not practiced to any extent in the fisheries of the western Atlantic, and though it appears less objectionable than almost any other method it is prohibited by the laws of Florida. The natural limitations imposed upon this fishery are stringent and are such as to prevent the depletion of most beds by this method alone. The sea must be moderate and the water fairly clear, while the brevity of the period of submergence and the length of the intervening rests, together with the small proportion of men who will develop into first-class divers, makes the devastation of the beds by such means a remote contingency. Although sponges unattainable by other means can be taken by this, the history of the Mediterranean beds leads to the conclusion that nude diving is comparatively harmless to the sponge grounds.

\section{MACHINE DIVING.}

The objections which have been urged against the use of the diving machine are resolvable into essentially two: (I) That the divers with their heavy-mailed shoes crush innumerable young sponges in walking over the bottom, and (2) that they take everything, large and small, leaving the bottom denuded of the growth essential for reproduction.

The first objection appears ridiculous to anyone familiar, either theoretically or practically, with the principles of diving. It is true that the diver as he appears 
on the deck of the vessel is burdened until he is hardly able to walk, partly by the essentials of his dress, but largely by weights which he deliberately adds for the express purpose of enabling him to keep on the bottom when submerged. After his descent, when his dress becomes inflated, it is necessary to release air from time to time, not only for purposes of respiration, but to prevent the buoyancy of his inflated suit from raising him to the surface, and should he lose a weight on a shoe he will immediately lose control of himself and float. It is one of the well-known restrictions of working in the diving dress that while a strong upward pull can be exerted a vigorous lateral push can be put forth only when the diver can place his foot or some part of his body against a fixed object, while even a moderately effective downward push or blow can not be delivered unless the operator can anchor himself by holding with his hand or other means. These restrictions in the employment of his full strength all result from the lightness with which the diver rests on the bottom, the ponderous and grotesque object which can barely stagger on the deck of the boat treading gently with but a few pounds pressure as he travels over the bottom. As the weight with which the diver actually treads could seriously injure none but the very smallest sponges, and as his footprints can not possibly cover more than a very small proportion of the ground over which he works, this objection to the diving machine can well be totally disregarded.

The second objection stated above is more serious. It has been claimed by some opponents of diving that the diver is unable to distinguish accurately the size of the sponges, owing to the optical conditions under which he works, while the advocates of the method claim that he is in much better position to do so than is the hooker, looking through a deep stratum of water of variable transparency. There is but little doubt that experienced divers, depending not only on eyesight but upon touch, can distinguish with sufficient nicety to avoid flagrant breach of the law and common prudence, but so long as undersized sponges have a market and infractions of the law are not punished they will not hesitate to pluck most of the young sponges which come in their way. Whether they do the damage knowingly or unwittingly is of no material moment, however, in the face of the fact that the damage is done, and there is no doubt that immense numbers of small sponges are brought in by the divers, many of them being sold in the exchange at Tarpon Springs, while undoubtedly a much larger number are shipped for sale in other markets. The proportion of these sponges to the total catch appears to be much larger than among the product of the hookers.

Another phase of this matter is concerned not so much with the taking of the young sponges as with the thoroughness with which the bottom is denuded of all sizes. In working over rough bottom especially, the hookers and harpooners always leave a considerable proportion of the sponges, not from choice but because they are overlooked, hidden from view from above or inaccessible 
owing to their situation in crevices or under ledges. These the divers are able to find and obtain and in consequence they leave fewer sponges to furnish the young necessary for the recuperation of the beds. Where the divers are working on grounds already partially depleted by other methods of sponging, as was the case during the first two years of the fishery in the Gulf of Mexico and in many places in the Mediterranean, there can be no doubt that the method is exhausting to the beds, even if it be conducted without the abuse of gathering undersized sponges. When the beds are already worked to or beyond their limits of productiveness any method which increases the draft upon them must be injurious.

This was one of the contentions of the opponents of diving in Florida and was the reason for the restriction of the divers to depths greater than 50 feet. It was hoped by this means to preserve the inshore grounds inviolate for the hookers, while permitting the taking of sponges in the deeper waters unattainable by the methods previously in use. Concerning the productiveness of these offshore grounds we are not yet in possession of data which would warrant an opinion of value, but the little that we do know does not indicate that they are more productive mile for mile than were the shoaler waters when first discovered. In fact, the bars appear to be fewer and more scattered, and though sponges occur on some of them in great numbers, this abundance is due to the fact that they are virgin beds and have never before sustained a fishery. There is no doubt that in time some, at least, of these will be depleted and the proximity of that time will be proportional in some measure to the intensity of the fishery and conversely to the area of new grounds developed.

Assuming that the fishery can be carried on to the 20 -fathom curve and that the productiveness of this region is proportionately equal to that covered by the hookers, an increase of from 250 per cent to 275 per cent in the annual product, making no allowance for the consideration about to be presented, would result in approximately the same degree of over-fishing which had gradually decreased the catch of the hookers prior to $1905-6$. This allowable increase was nearly attained in the year ending May I, 1907, when the value of the sheepswool product was over twice the normal of the years immediately preceding. Owing to the sudden increase in the supply the price dropped far below that of previous years.

In discussing the effects of the fishery upon the rate of depletion of the inshore beds, consideration must be given to the effect upon their recuperative powers of the sponges lying in the deeper water, beyond the reach of the hookers but now being taken by diving. Undoubtedly a considerable proportion of the young sponges on any bed are the offspring of breeding adults in the immediate vicinity, either overlooked by the hookers, concealed from sight under ledges, or protected from capture by the prevailing turbidity of the water, all factors 
less operative with the divers; but it is equally beyond doubt that no inconsiderable proportion are derived from sponges in deeper water, at a distance from the beds on which the young finally settle.

We have evidence that this must be true in the phenomena of the recuperation of large areas after the practically complete extermination of the sponges from so-called "poison water." This has recurred at irregular intervals about ten years apart. In I 878 , for instance, practically all sponges accessible to the hookers between Johns Pass and Cedar Keys were destroyed and the fishery was abandoned for several years, the first sign of recuperation being observed about I 882. About 1895 a similar occurrence in the northern part of the Bay grounds killed the sponges between St. Marks and the mouth of the Suwanee River from about the 5-fathom curve to the greatest depth explored by the hookers, and in I90I I was informed that the first sponges taken since then from the depleted bed had been obtained recently.

The evidence all indicates that over the large areas involved few if any sponges escaped the disaster, and as the repopulation of the beds was apparent practically simultaneously over the whole area and did not appear first merely at its edges, it is evident that the young must have been derived from grounds more or less remote. The very young sponge is a free-swimming organism which is probably often carried far by currents before it reaches the stage at which it settles down and becomes fixed. It is evident that the rate or probability of recuperation of any exhausted area depends not only on the number of resident breeding sponges, but also upon the presence and number of such sponges on surrounding areas. An exhausted area adjacent to virgin beds will have a more abundant set of young than if the surrounding areas are equally exhausted. In the history of the sponge grounds of the Gulf of Mexico prior to 1905 there were always untouched bars offshore just beyond reach of the hooks, and these must have supplied untold millions of fry to the workable beds, retarding their commercial exhaustion. This condition is now changing, for the offshore beds themselves are yielding up their sponges in large numbers, and even if they exist in still deeper water than has been explored the virgin beds are becoming more and more remote from inshore waters. It would appear, then, though the basis of the conclusion is purely a priori, that, in view of the increasing exploitation of the deeper beds, the grounds now reserved to the hookers will probably not have the same powers of recuperation in the future as in the past, and that with the same expenditure of effort in the fishery the product of these beds will tend to fall at an increasing rate. The consequence of this will be that the principal seat of the sponge fishery will gradually move into deeper and deeper water until the limit is reached, either by the depth in which it proves practicable to work or by the attainment of the limits of sponge production, which may be fixed by either the depth of water or the absence of suitable bottom. 
The introduction of diving came at a time when the older method of sponging had finally demonstrated its inadequacy to supply the demand for sponges, and by developing new beds it has deferred the time when the Florida sponge beds will no longer be able to sustain the demands of the markets. On the other hand, it will undoubtedly operate to retard the recuperation of beds already or about to become exhausted, and will, of itself, tend to depopulate the beds on which it is carried on and, indirectly, the hooking grounds adjacent to such beds. From the comparative facility with which it can be conducted, irrespective of the condition of the water, the thoroughness with which the bottom can be scoured and the reckless disregard of the future with which the divers gather small sponges, diving is undoubtedly more dangerous in the denudation of the beds than is hooking. The recent legal restriction of the fishery to the deeper waters and to the more boisterous season of the year, when many days are lost on account of stormy weather, will operate to curtail the catch and the profits and restrict the number of persons engaging in it, and to this extent the conservation of the beds will be accomplished. What may be the ultimate result of the introduction of the diving machine will depend largely upon the area and productiveness of the beds outside of the 8-fathom curve. If they be four or five times as great as those of the beds within that limit, the Bay grounds can support a profitable fishery for some years to come, but if they are no greater than there is now reason to suppose, the effects of the fishery will become apparent within the next five years.

\section{DREDGING OR TRAWLING.}

The dredge or gangava is not used in Florida or the West Indies, but the testimony of European authorities and an appreciation of the effects of the dredge and beam trawl used by naturalists indicate that without regulation its effects must be disastrous. If used in profound depths to take sponges wholly beyond the reach of other methods of the fishery it has some justification, but even then it would probably retard the recuperation of the adjoining beds in more shallow water in the same manner as denudation by the scaphander would curtail the supply of young sponges on still shallower beds.

There can be no doubt that the gangava is a destructive engine. With it there can be not even such imperfect selection as is exercised by the hooker and the diver, and the proportion of young sponges brought up is correspondingly greater. On the banks of Lampedusa, where the gangava and the scaphander work practically side by side, it is stated on the authority of Lucifero that the refuse sponges brought up by the former constitute 25 per cent of the total catch, while but 6 per cent of the diver's catch is composed of refuse, small, and seconds. It is stated, also, by the same authority, that owing to the damage done to small sponges it requires five years for banks to recover from the effects of dredging, and even then the crop is limited, while two years suffices for the 
recuperation of beds exhausted by diving, and the crop then produced is comparatively abundant. While the hardships and personal risks of the dredgers are negligible as compared with those attending diving, the effects on the beds are far more disastrous.

Owing to the comparatively small expense for equipment and operation, and the fact that dredging can be carried on in all depths and in weather which would inbibit other methods of fishing, it is possible by this means to conduct a fishery of great intensity and to exploit grounds so depleted as to be unprofitable for diving. It is by no means certain that the offshore grounds of Florida are not too rough for the gangava, but to prevent the introduction of this method of fishing in shallow water and to forestall the establishment of a "vested interest" which might be difficult to deal with in the future, it is desirable that legislation be passed restricting the use of the dredge to depths far beyond those which it is possible to exploit by other means.

\section{THE REGULATION AND PROTECTION OF THE SPONGE FISHERIES, WITH PARTICULAR REFERENCE TO FLORIDA.}

\section{MEASURES IN FORCE.}

Until recently the regulation of the sponge fisheries of the Mediterranean has been, with few exceptions, concerned chiefly with the production of a revenue for the governments concerned, but during the past fifteen years, owing chiefly to the efforts of Mr. Charles Flegel, another element has been introduced, the protection of the spongers themselves from the physical effects of their calling.

It is true that in a few places measures are in force which tend to protect and conserve the sponge beds. In Dalmatia recent attempts to introduce the scaphander and the dredge have met with opposition and interdiction, and the sponge banks are opened to the other spongers only during alternating periods of two years. A somewhat similar regulation is proposed for the Bay of Taranto. In Cyprus the dredge is entirely prohibited, and in Egypt its use is authorized only in depths greater than 262 feet, where it is impossible to take sponges by any other means. In Greece, Tripoli, Tunis, and on the banks of Lampedusa all forms of apparatus are permitted under varying conditions as to taxes and licenses; but in Turkey, Egypt, Crete, and the principality of Samos the scaphander is prohibited on broad economic and humanitarian grounds rather than for the narrower consideration of the protection of the sponge beds, and for the same reason Greece has attempted to regulate the maximum depth to which this apparatus may be used without restricting in any way its employment in shoaler waters, in which it might be supposed to do greater damage to the beds. The attitude of the Greeks in this matter is readily understood, for they are dominant in the fishery and most of their diving is carried on in waters away from home. 
In Florida, the Bahamas, and Cuba, while the matter of revenue has been by no means overlooked, more consideration has been given to questions of conservation of the fisheries, the measures adopted being the prohibition or restriction of the use of supposedly destructive forms of apparatus, the establishment of close seasons, and a minimum size of sponges which it is permissible to take.

In the Bahamas, Cuba, and the territorial waters of Florida both the scaphander and the dredge are absolutely prohibited, Florida also including in the interdiction all methods of diving, either with or without apparatus. In Cuba the sponge beds are all in territorial waters, and as the Bahama government without challenge assumes jurisdiction over the entire area of the banks, neither of these countries has much difficulty in making the legislation effective. In Florida, however, a difficulty confronts those interested in the conservation of the industry.

On the Bay grounds in the Gulf of Mexico practically the entire spongebearing bottom is outside of territorial jurisdiction, beyond the 3 -mile limit, and therefore in neutral waters not subject to direct regulation of either state or national government. So far as this region is concerned, therefore, the laws of Florida are from the nature of the case inoperative, and to obviate the difficulty the Congress of the United States has recently enacted laws prohibiting the landing of sponges taken by diving between May I and October I, those taken by diving at any time in water less than 50 feet in depth, and all sponges of less than 4 inches in their largest diameter taken by whatever means.

The effect of the federal laws, taken in conjunction with those of the state, is, therefore, to prohibit the landing or sale of sponges having a maximum diameter of less than 4 inches; to prohibit naked or skin diving and the use of the scaphander by American vessels fishing for the American market in depths less than 50 feet, and in any depth during the seven months from May I to October I; and to prohibit the use of dredges on the Bay grounds within 3 miles of shore, where there are no sponges, while permitting their use outside of that limit, where the sponges actually exist. No legal restriction is imposed on hooking excepting that applying to the minimum size of sponges which may be caught, landed, or offered for sale. There is no prohibition, nor from the nature of the case does such prohibition appear possible, against either American or foreign vessels using the scaphander at any time anywhere outside of the 3 -mile limit, provided that the product of such operations be not landed in an American port except by regular entry and payment of duty as a foreign product.

On the Key grounds these difficulties are not encountered. The waters are shoal. The sponge beds are within territorial limits and under state control, and the federal statutes therefore do not apply and are not necessary. 
MEASURES PROPOSED.

The possible measures for the regulation and conservation of the sponge fisheries resolve themselves into (I) the prohibition of taking sponges below a given minimum size, (2) the establishment of close seasons, (3) the restriction of the character, amount, and location of the apparatus employed, and (4) sponge culture. As has been previously indicated, the taking of young sponges is one of the great abuses of all sponge fisheries, and that one most fatal to the perpetuation of the beds; and young sponges are taken by all present methods of fishing, though to varying degrees. A few of them are thrown away by the fishermen, but the vast majority are placed on the market. I have seen 30,000 small sheepswool sponges in the house of one dealer at Tarpon Springs, who paid but $\$ 500$ or $\$ 600$ for the lot, an average of less than 2 cents apiece. This was probably the largest quantity bought by any one man at that place, but the other dealers also had large numbers, and it is notorious that the divers ship many away for sale in other places. It is impossible to state the total number of young Florida sponges annually placed on the market, but there must be at least between 150,000 to 200,000 pieces. Accepting the lower estimate, these are worth to the spongers not over $\$ 3,000$, but if left to grow for another year they would more than double in weight and increase about ten times in value at the present prices. Not only is there this direct monetary loss to the fishery, but there is an indirect loss to the beds resulting from the unprofitable removal of this large number of breeding individuals capable of furnishing fry for the regeneration of the sponging grounds.

The present minimum limit placed on sponges by both the federal and state statutes applicable to Florida waters is 4 inches in the longest diameter when wet, but most persons do not realize the small size of such sponges. The dealer mentioned above was of the belief that all of his 30,000 small sponges were under the legal limit, but a careful measurement showed that probably 50 per cent of them could be construed as complying with the conditions of law, the largest diameter reaching 4 inches, though the other dimensions were usually considerably less. The average weight of such sponges when pure and perfectly dry is less than one-half ounce and they are of little value in the markets. To sell most of them at all it is necessary to bleach them and place the price so low as to leave little profit. If the law is to be made really effective for the protection of the beds and to prevent the taking of economically unremunerative sizes the minimum limit must be raised to 5 inches and the law must be rigorously enforced against spongers, buyers, dealers, and others who are concerned in its infraction. It is believed that most of the buyers and vessel owners at least would welcome more rigorous measures, which would work no hardship to any- 
body if enforced on all without prejudice or favor. The difficulty now is that each man feels that the law will be broken with impunity by some of his competitors and that he may as well get his share of such profits as may accrue from disregard of the regulations.

The amendment and enforcement of the law as suggested will not restore the depleted beds to their pristine productiveness nor prevent the partial depletion of beds at present more or less unimpaired, but it will prevent the ultimate commercial extinction of the sponges and will insure for all years to come at least a partial crop from all beds now known or which may be hereafter discovered. As to the foregoing there can be no room for discussion among fair-minded and disinterested persons, but in regard to close seasons the various suggestions that have been made from time to time are open to more or less difference of opinion. The following propositions all have their advocates: (I) The closure of all beds during the spawning season, (2) the closure of all beds for a part of each year irrespective of the spawning season, and (3) the alternating or rotative closure of some of the beds for a longer period while all other grounds are open to more or less unrestricted fishing.

The first suggestion appears to me to be futile and ineffective. In the first place a difficulty presents itself from the circumstance that the sponge, at least in the warmer waters, spawns more or less generally throughout the year, though the greater number of embryos are emitted during spring and early summer. This, however, would be a minor consideration if much were to be gained, for the period selected for closure could be made to correspond with the time of maximum discharge of young, but nothing more would be accomplished than by closing the beds for an equal period at any other season of the year. Whether a breeding sponge is taken before or during the spawning season the loss is the same so far as its potential powers of reproduction are concerned.

The close season embracing a part of each year, similar to that established for the scaphander in Florida from May $\mathrm{I}$ to October I, or the Tunisian regulations of like import, is of value chiefly in restricting the catch and leaving a larger number of sponges on the beds. If by an increase in the intensity of the fishery as many sponges are taken in the shorter period as would otherwise be caught in the entire year, practically nothing is gained, for the duration of closure is too short to permit the protected sponges to increase very materially in size and, as stated above, the protection of spawning as distinguished from nonspawning mature individuals is immaterial. Where, as in Florida, the open period is made to coincide with the season under which the fishery is most subject to difficulty and interruption, the regulation is made more effective in protecting the beds by a reduction in the profitableness of the operations and the consequent discouragement of increases in apparatus, personnel, and intensity of the fishery. 
A somewhat different aspect is presented by the proposition to close the grounds in rotation for periods of a year or upward. This would tend to intensify the fishery on the open grounds but would compensate for this by providing periods of rest, recuperation, and growth. By periodically closing a portion of the grounds for terms of say two years, there would be given to many of the small sponges already set an opportunity to grow to marketable size, the sponges already marketable would increase very materially in size, weight, and value, and these two would in turn result in the production of a larger number of embryos and a heavier set of young. Notwithstanding that many of the spongers and others interested in the business believe to the contrary, a period of two years is not sufficient to produce a merchantable sponge from the egg, and the earlier set of the closed period would not be ready to market until a year or two after the area was again opened to fishing. Even upon the impossible assumption that all marketable sponges were removed during the first open year, if the young were properly protected in accordance with previous suggestions the good effects of the closure would be apparent over a term of several years.

The practical impediments to the application of this system of protection to the waters of Florida lie mainly in the necessity for making the required subdivisions of the grounds rather small and generally distributed, and the consequent difficulty in securing its enforcement. It would not be feasible, for instance, to close the Bay grounds north of Cedar Keys and open them south of that place for the reason that the water might be turbid in the latter area while clear in the former, to the utter prostration of the fishery and the ruin of those engaged in it. To guard against such contingency it would be necessary to divide the whole area into transverse strips, say ro miles wide, closing alternate zones or every third zone, as the case might require, leaving the others open. It would be necessary to mark these areas adequately with buoys and to establish a patrol to enforce respect for the regulations. Moreover, as most of these waters are outside of marine jurisdiction, it would appear possible to make the regulations effective to our own fishermen only, though the distance from foreign ports would probably act as a geographical deterrent to the depredations of foreign vessels. In any event the regulations would be difficult to enforce even with the assistance of several guard boats. This is probably the best and most effective type of close season, though presenting practical difficulties of enforcement; but it also is in essence a restriction on the intensity of the fishery and consequently on the yield, and whether it would add materially to the productiveness of the long-used hooking grounds is a matter of grave doubt; however, it might operate as insurance against ultimate depletion. It is practically the method which nature already enforces in places by prolonged periods 
of turbid water, the effectiveness of which we can determine by a comparison of the present condition of the grounds with their past.

Restrictions upon the character, amount, and location of apparatus and methods are designed either to suppress destructive or wasteful fisheries or to curtail the use of efficient methods which are not inherently destructive or wasteful, though they may become so in the employ of the reckless or unprincipled. Examples of the first type of legislation are seen in the prohibition of the use of the dredge in Florida, the Bahamas, Cuba, and Cyprus and its restriction to great depths off the Egyptian coast. There is no doubt that such regulation is in the interests of the fisheries. The dredge has no place in a well-regulated fishery in depths approaching those that can be exploited by other means. It may be effective, but it is also inordinately destructive, and the sponge fisheries of this day are in no condition to support unnecessary and preventable waste.

The federal and state legislation restricting the use of the diving machine to depths of not less than 50 feet is an example of the second type of restriction of apparatus. Properly conducted diving is inherently neither destructive nor wasteful. Its chief menace to the beds, if the taking of young sponges be prevented, lies in its efficiency and the thoroughness with which it operates to denude them. It is intense in its effect, and the legislation directed at it is intended to confine and limit it and to preserve both the inshore and offshore beds by practically restricting its efficiency and the volume of its catch. The restriction of the scaphander to water deeper than 50 feet is absolutely necessary for the conservation of the beds already shrinking under the operations of the hookers. Later it may be necessary to protect the divers from themselves and fix a maximum depth beyond which they may not go.

The three general means of regulating and conserving the sponge fisheries above discussed are applicable to the public beds, limiting the intensity of the fishery, aiming to secure and maintain what we have rather than hoping to add to it. They are restrictive and conservative rather than constructive, and without the discovery of new grounds offer little hope of maintaining the supply in equilibrium with the constantly growing demand.

The fourth method, sponge culture, is on the contrary concerned with the sponge industry rather than the sponge beds. It is constructive, aiming to add to the sponge supply of the future without particular regard to the source of supply of the present. It apparently offers the only hope of permanently maintaining the sponge fisheries in those countries in which they are now established, though the discovery of extensive beds in other parts of the world may make it not absolutely necessary for the prevention of an ultimate sponge famine. As it is at present not applicable to the public beds, but even more than oyster culture susceptible of development by private enterprise only, discussion of it is reserved for another paper. 


\section{CONCLUSIONS AND RECOMMENDATIONS AS TO THE FLORIDA SPONGE FISHERY.}

All known and exploited sponge beds, in whatever part of the world, are showing more or less marked indications of depletion, and in some places, notably the Key grounds and to a less extent the Bay grounds of Fiorida, there has been under average conditions a conspicuous falling off in the product. By the introduction of improved methods of fishing the yield has been temporarily increased in some places, but there is no reason for believing that these increases can be indefinitely maintained or materially augmented.

Such depletion as has occurred is in part due to the taking or destruction of small sponges, but is attributable principally to the intensity of the fishery rather than to preventable abuses. The demand for sponges, especially for those which are employed in the arts and industries, is constantly growing. Countries which formerly used practically no sponges develop a demand with the growth of manufactures, and countries which for years have used sponges now require many more than they did a decade or two ago. In I 880 the United States used about $\$ 394,000$ worth of sponges and in I 900 about $\$ 987,689$ worth. In the fiscal year 1907 , with a domestic crop of $\$ 854,583$, imports of $\$ 488,426$, and exports of $\$ 247,145$, the apparent consumption was $\$ 1,095,864$, but of these a considerable quantity were in the warehouses of the dealers at the end of the year. The increase noted is due in part to higher prices but largely to greater consumption. The demand is outrunning the supply and to satisfy it the beds are being scoured as never before. New and more efficient methods are being introduced, while the fishermen using the old methods on old grounds are taking fewer sponges individually but still find the fishery more or less profitable owing to the higher prices which they are able to obtain.

The outcome of these conditions is inevitably the ultimate depletion of the beds or the economic limitation of their product. The world can produce annually by natural processes alone only a certain more or less definite quantity of sponges. It is obvious from the facts which have been set forth in preceding pages that many beds have reached their limits of productiveness, and that were it not for the higher prices of to-day they could not be fished with profit by the methods which proved lucrative in former years. A bed from which a fraction of the sponges has been removed has not the reproductive and recuperative possibilities which it possessed in its virgin state. Worked as intensely as they are to-day the sponge grounds can not improve; they are almost certain to retrograde, but by wise regulation some of them may be maintained in approximately their present condition of productiveness.

The discovery of great sponge fields in places in which they are not now known or developed, in Australia and the Philippines, for instance, may provide for the future growth of the world's demands, but that will be of no value to 
fisheries already established, however desirable it may be from the standpoint of the consumer. Exhausted or partly exhausted fisheries must suffer if brought into competition with those whose productiveness is unimpaired and whose product may be put on the market at a lower price. Those countries which have with forethought provided for the contingencies of the future are those whose fisheries will be best fitted to survive competition, or, should that not come, be in a position to reap the greatest profit from the increased demand for their product.

To secure to the people of Florida the conservation of the natural beds, for the maintenance of the fisheries already established, to regulate those which may be introduced in the future, and to provide for an increase in the sponge supply to meet the growing demands of civilization, changes in the federal and state statutes are suggested to meet the following requirements in addition or amendment to those already provided for:

r. The minimum size of sponges allowed to be taken, landed, or sold should be increased from 4 inches to 5 inches in their maximum diameter. This would prevent the present wasteful destruction of sponges commercially almost worthless, would conserve the beds, and after one year would increase the income of the fishermen without materially decreasing it in the meantime.

2. In addition to the restrictions now in force, the use of the scaphander should be prohibited in water deeper than 20 fathoms. This is intended primarily as a hygienic measure, to protect the divers from the evil results attending work in deep water, but it will also indirectly protect the workable beds by maintaining outside of them a possible reserve of spawning sponges to supply them with young.

3. Gangavas, dredges, trawls, and similar instruments for scraping the bottom should be prohibited in depths of less than 30 fathoms. This regulation, while not required by any present development of the fishery, will prevent the sudden unregulated development of a method which would undoubtedly be destructive to the inshore grounds.

4. State and federal laws should be enacted for the encouragement of sponge culture in both territorial and extraterritorial waters, securing to private individuals or corporations the sole use, under proper restrictions, of suitable areas of the bottom for the purpose of raising sponges by artificial means. In case of further depletion of the natural beds, or with the growth of demand and the failure to discover new and more productive grounds, sponge culture offers the only possible means of prevention of a practical sponge famine. With the development of sponge fields in other parts of the world which would be serious competitors with the depleted beds of Florida, the practice of an economic system of sponge culture is the only means which would prevent the extermination of the lucrative sponge business of the state. 


\section{BIBLIOGRAPHY.}

In addition to various papers in the publications of the Bureau of Fisheries, the Deutscher Fischerei Verein, United States Consular Reports, and the statistical publications of the United States, Mexico, Cuba, and the Bahama Islands, the following have been consulted in the preparation of this paper:

Aliod, Rodolfo, et al. Relazion sull audamento della pesca maritima, Trieste, i 898.

Совв, J. N. The sponge fishery of Florida in rgoo. Report U. S. Fish Commission 1902, p. 161-175, pl. 6-9. 1903.

ConTE, J. Éponges. In: L'industrie des pêches aux colonies. Exposition Coloniale de Marseille, Igo6, t. I, p. 2 I0-26I, pl. I-II, text fig. 7-8. Marseille, I9o6.

La pêche dans les diverses colonies. Tunisie. In: L'industrie des pêches aux colonies. Exposition Coloniale de Marseille, I906, t. II, p. 64-78, pl. viI. Marseille, 1906.

FABER, GEORGE L. The fisheries of the Adriatic, p. 96-97. London, 1883.

Giacobini, Enrico. La pesca in Italia. Rivista Mensile di Pesca, anno viri, no. 8-9-10, p. $228-243$. Milano, 1906.

GodErRox, JosEPH. L'état actuel de la biologie et de l'industrie des éponges. Revue Générale des Sciences pures et appliquées, t. 9, I 898 .

Gourret, Paut. La pêche et l'industrie des éponges. Memoires et Comptes rendus des séances du Congrès International d'Aquiculture et de Pêche, Paris, I900, p. 297-320, 7 text fig., 3 pl.

Graells, Mariano. L'exploitation des éponges à Batabano. Revue des Sciences naturelles appliquées, 41 année, p. IO3-112. Paris, I894.

Hyatr, A. Revision of the North American Poriferae. Memoirs Boston Society of Natural History, vol. II, pt. IV, 1877 , p. II -84 , pl. I5-I8.

VON LENDENFELD, RoBERT. A monograph of the horny sponges. 936 p., pl. I-50. London, I889.

LUCIFERO, A. La pesca delle spugne nel Mare di Sicilia. Neptunia Rivista Italiana di pesca ed Aquicoltura, vol. Xx, no. 8 and 9, I905, p. I I3-145. Venezia, I 905.

Rathbun, Richard. The sponge fishery and trade. The Fisheries and Fishery Industries of the United States, sec. v, vol. II, I887, p. 8 I $7-84$ I.

Ravndal, G. BiE, U. S. Consul at Beirut. Sponge fishing in the Levant. Scientific American, 1902.

"REBUS." Official introduction to Bahama fisheries. I 8 p., published as handbook at International Fisheries Exhibition. London, 1883.

Seurat, L. G. L'éponge. Bulletin de la Société Nationale d'Acclimatation de France, 48 année, p. 257-282. Paris, rgor.

Smrrh, H. M. The Florida commercial sponges. Bulletin U. S. Fish Commission, vol. xvIr, I897, p. $225-240$, pl. 12-31, I 898 .

Notes on the Florida sponge fishery in 1899. Bulletin U. S. Fish Commission, vol. xrx, 1899 , p. I49-I5I, I90I.

WeIL, Georges. La pêche des éponges. Memoires et Comptes rendus des séances du Congrès International d'Aquiculture et de Pêche, Paris, I900, p. I83-I88.

Wolfrom, Gustave. Les pêches maritimes de la Tunisie. Bulletin de la Société Centrale d'Aquiculture et de Pêche, $t . x v, 1903$, p. 69-73.

Les pêches des éponges en Tripolitaine. Bulletin de la Marine Marchande, t. I, no. 2, 1899. 



\section{Plate XXX}

Rock Island sheepswool sponge. Natural size. 
XXX 91619

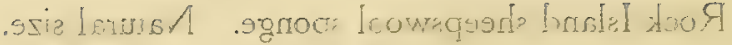




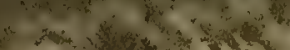

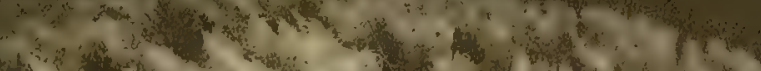

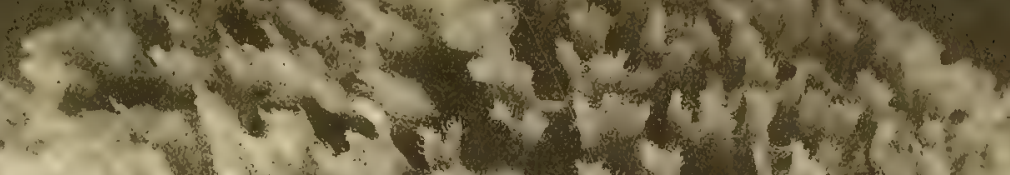

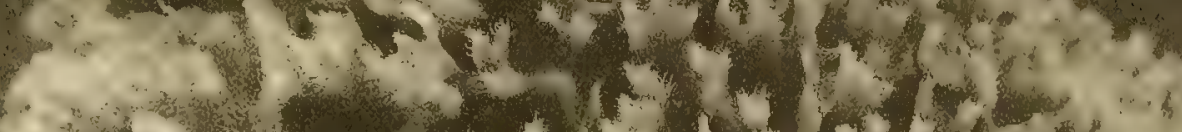

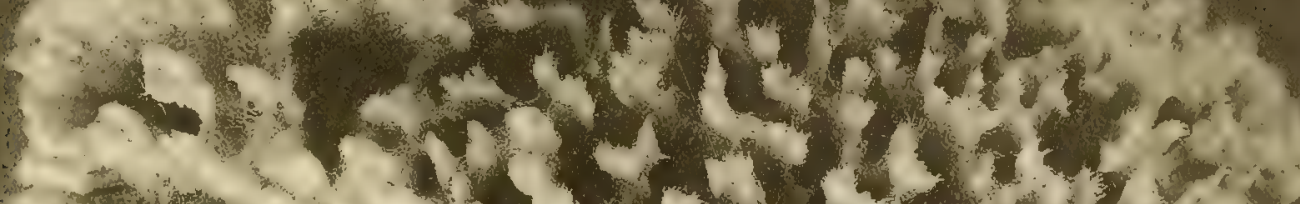
(3)

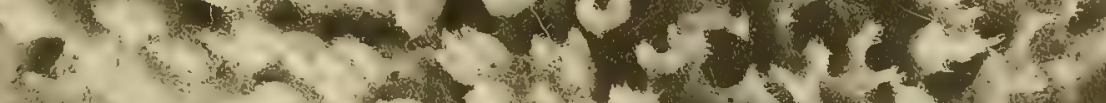

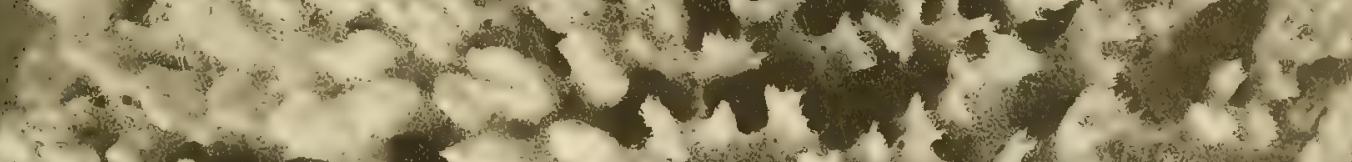

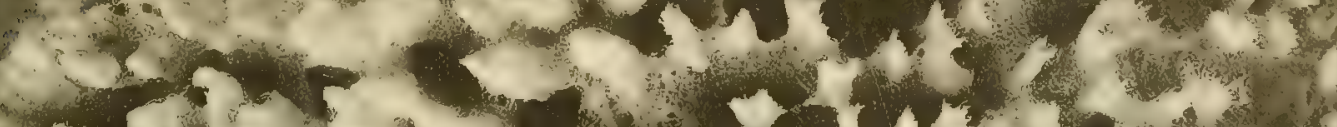

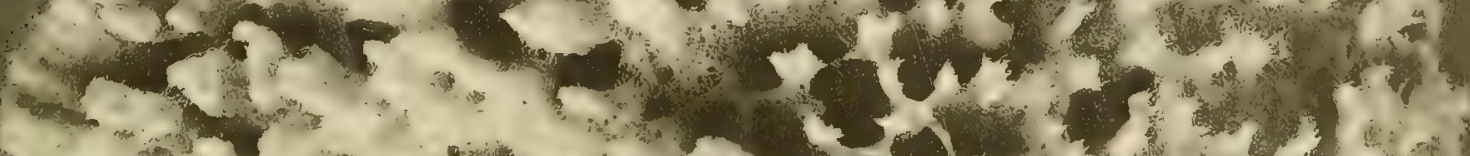
4 (n)

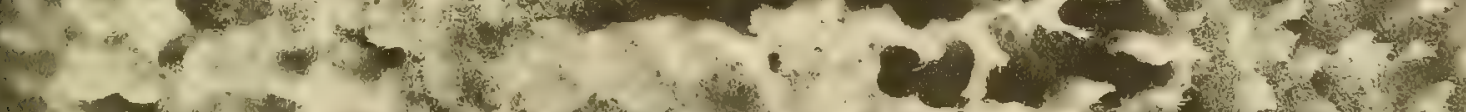

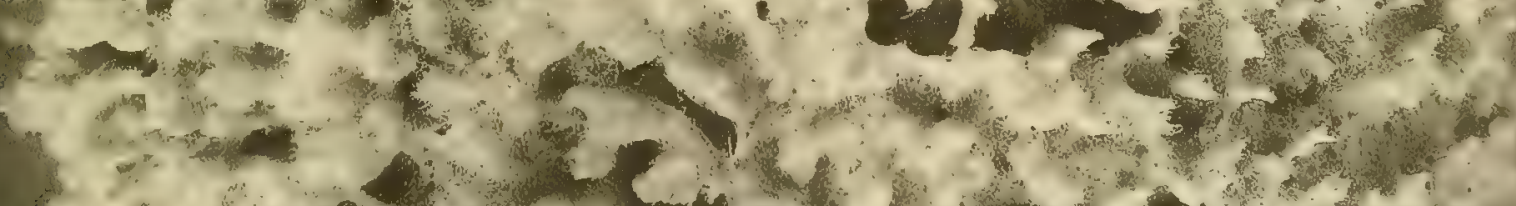

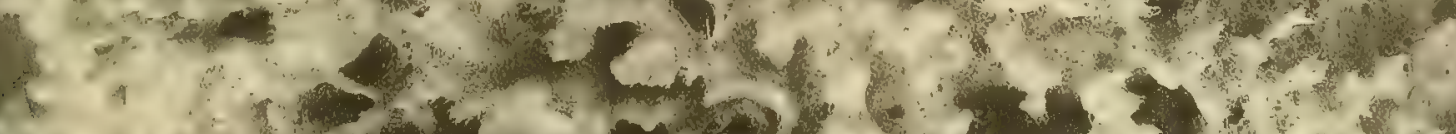

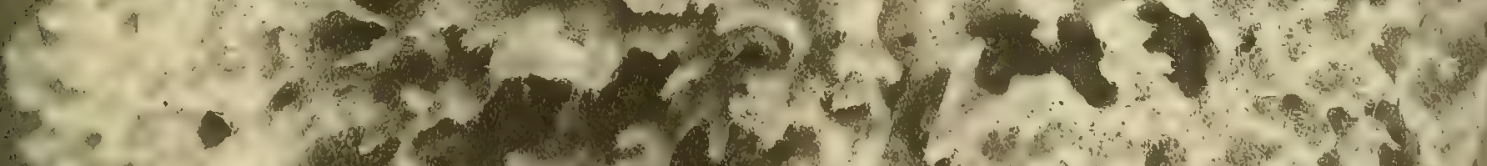

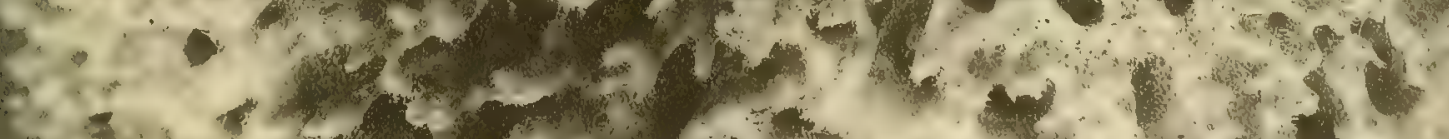

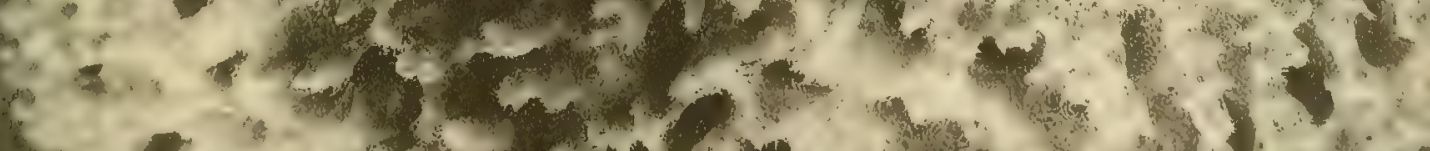

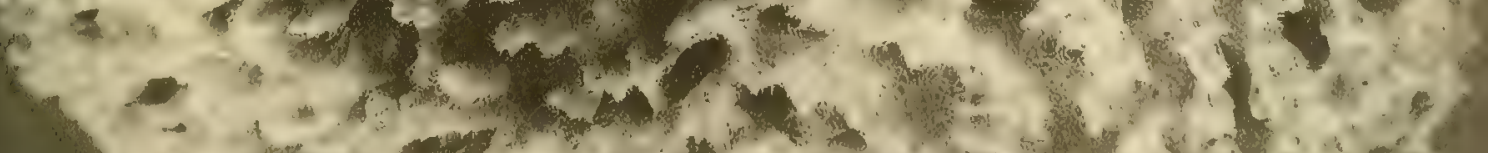

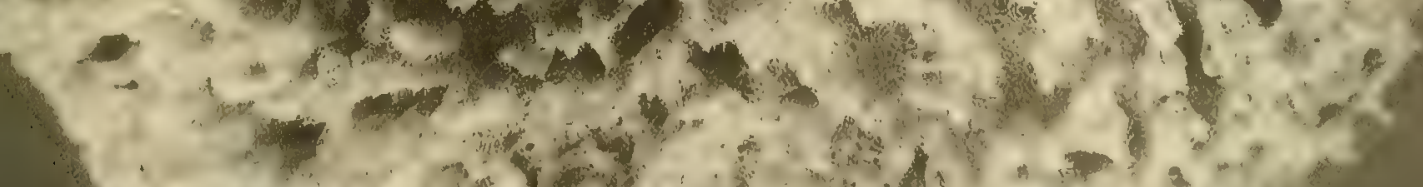

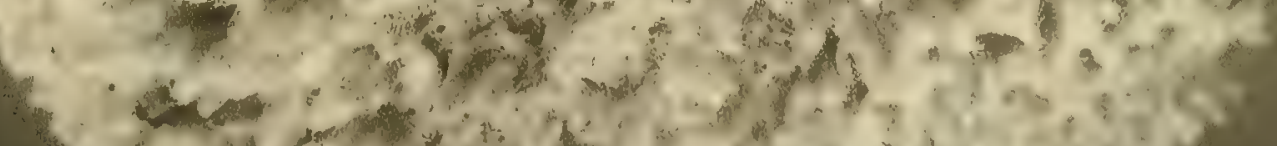

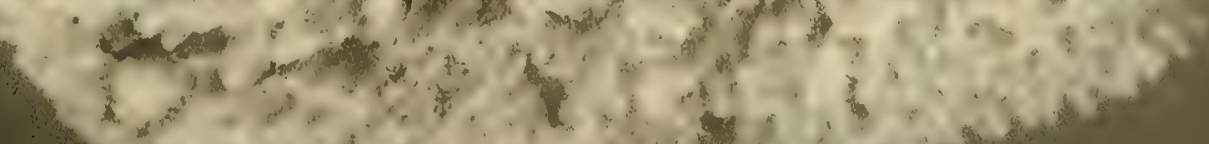

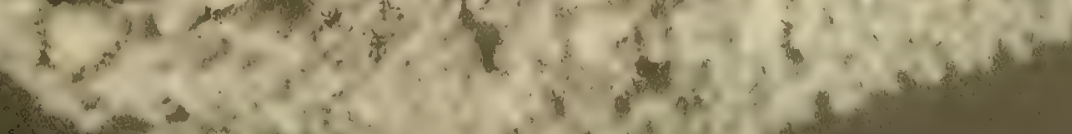



Plate XXXI

Rock Island sheepswool sponge, top view. Three-fourths natural size. 
WY.

.9xia Isxut 


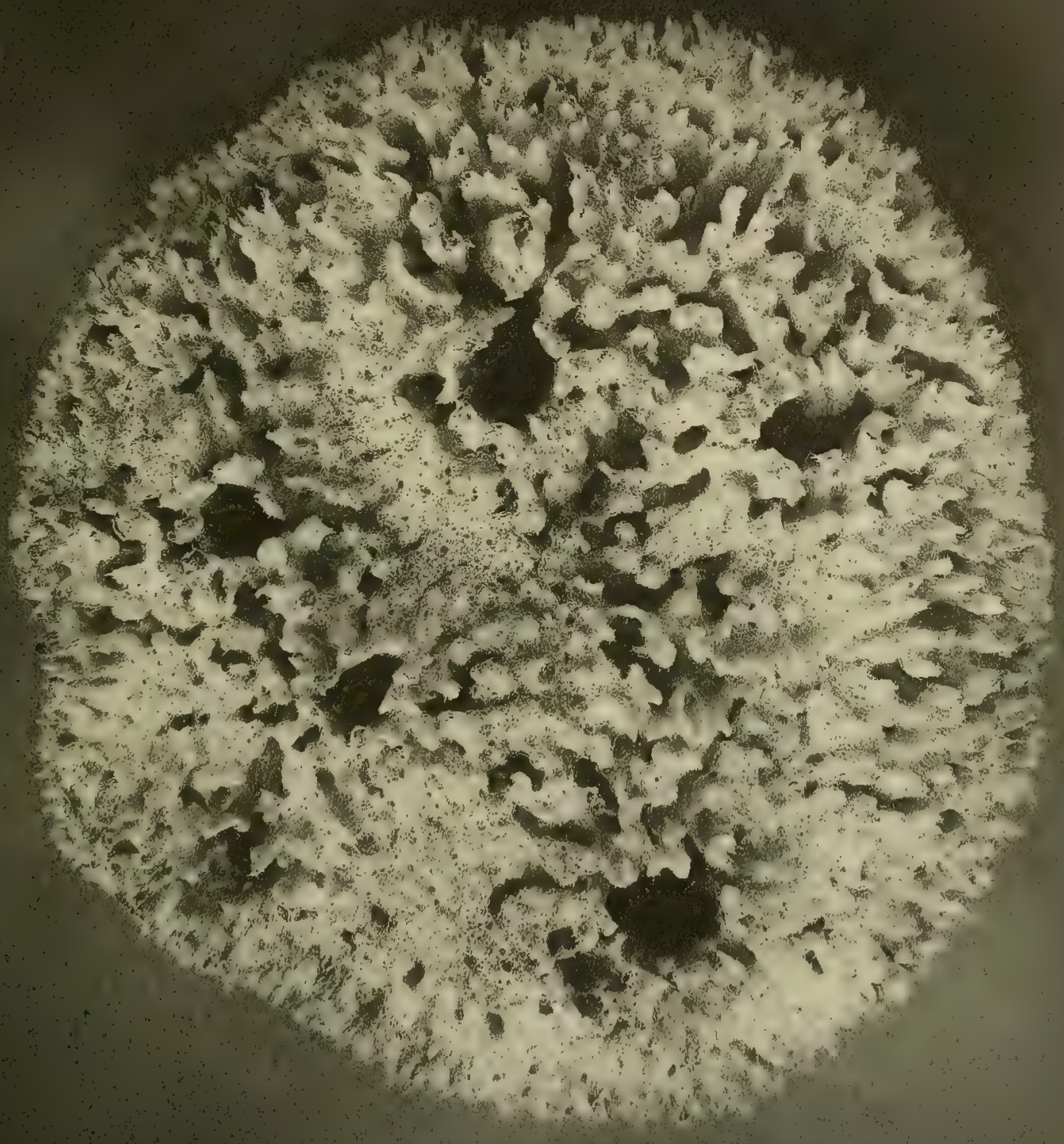





\section{Plate XXXII}

Florida Key sheepswool sponge. Natural size. 
IIYXX ats 19

.95ге I 


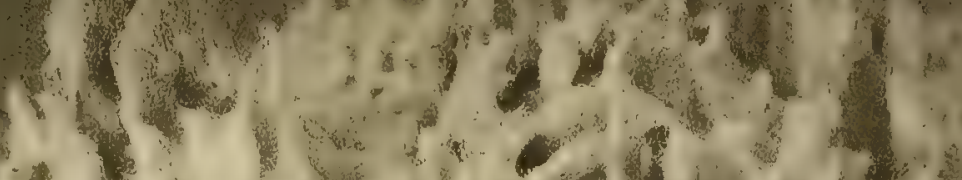

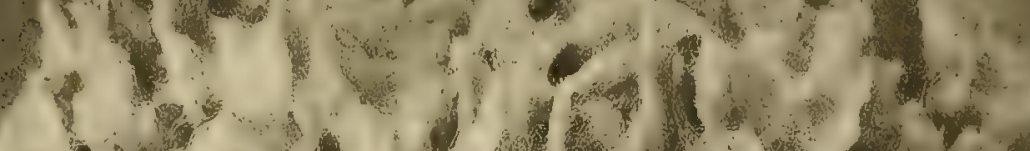

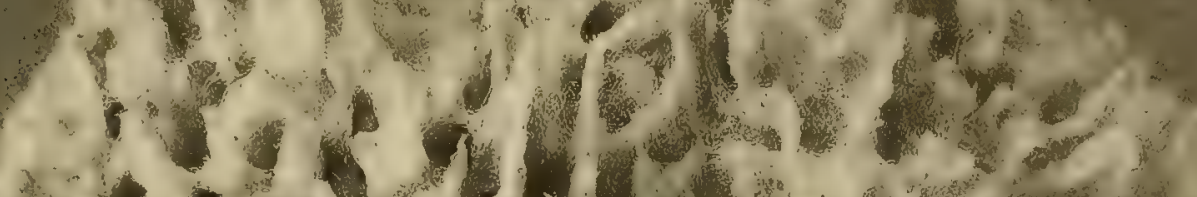

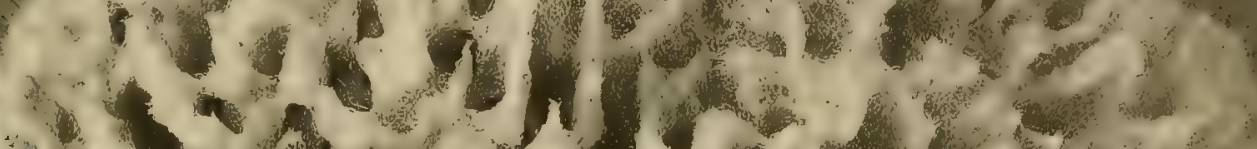

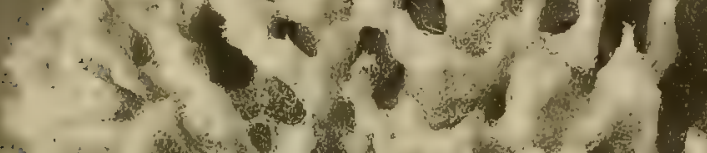

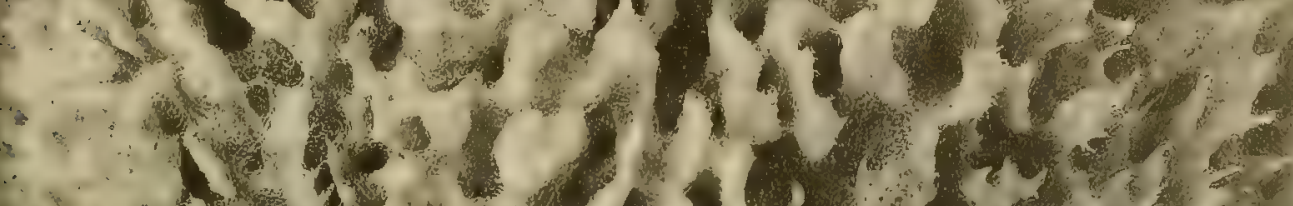
$\therefore$ (1) $\therefore$

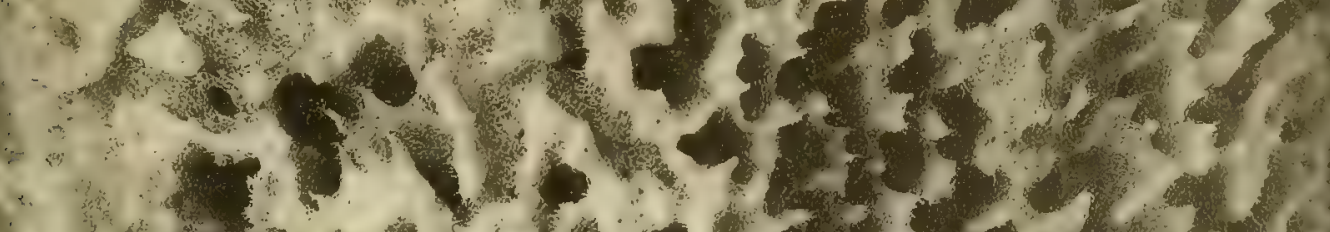

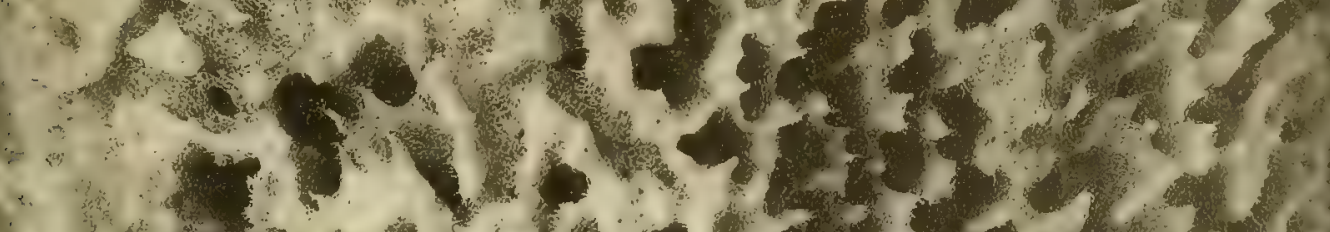
,

s. $x^{3}$.

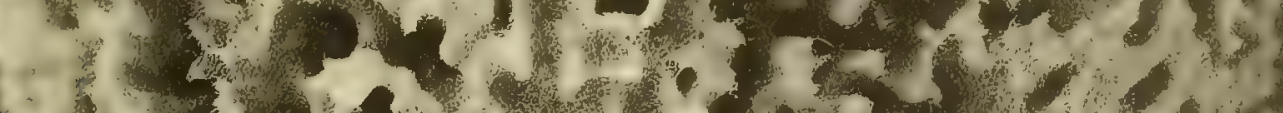
1. W

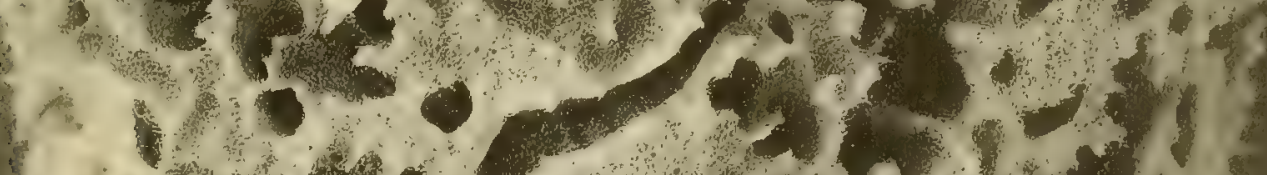

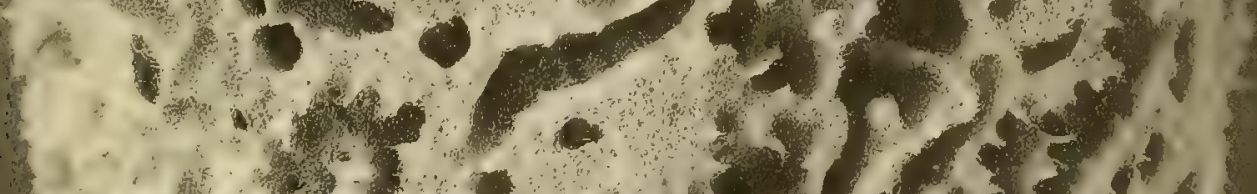

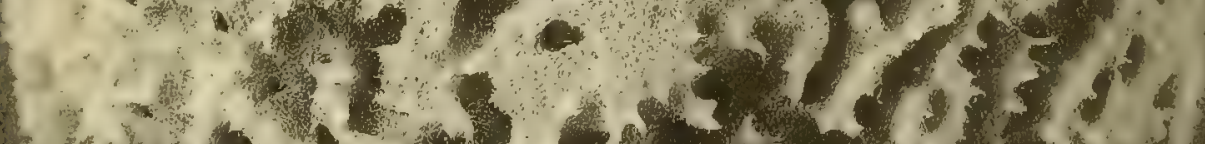

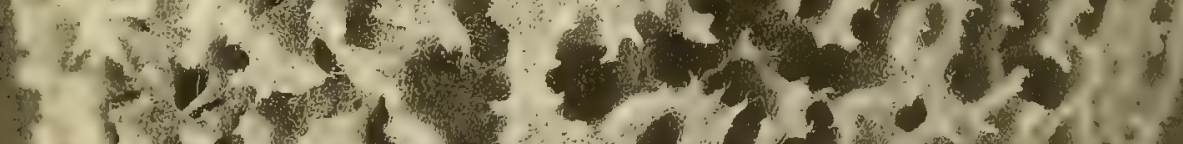

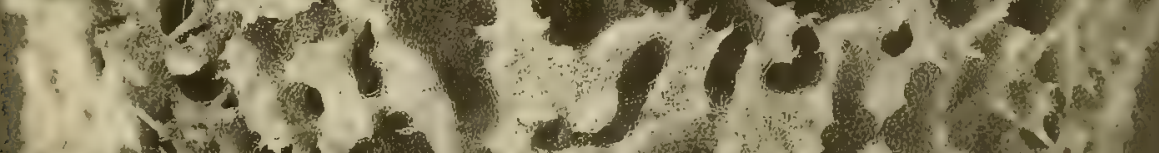

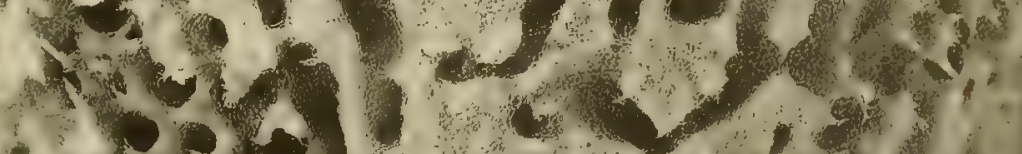

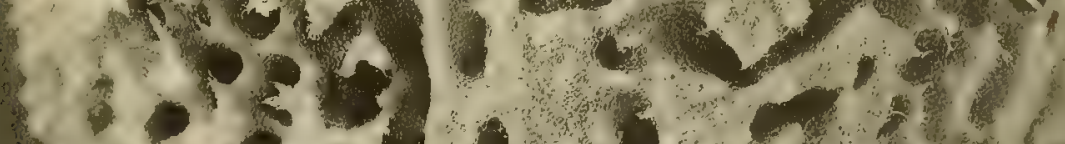

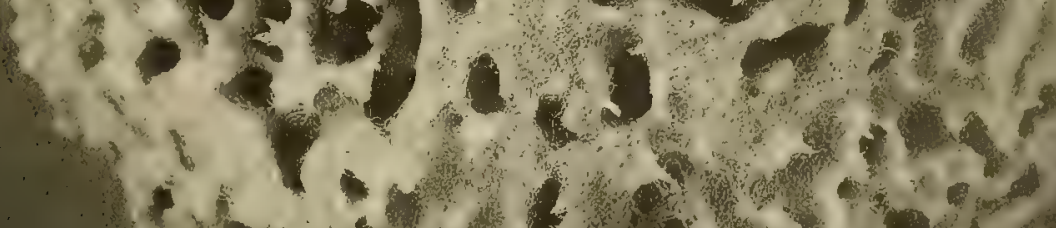
$1+100000$

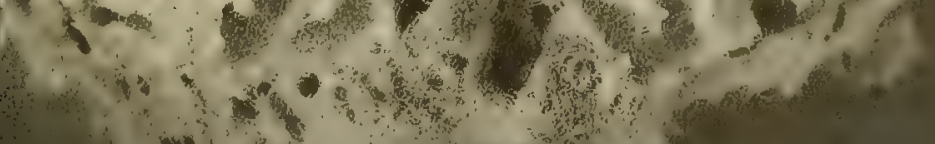
(2) 

Plate XXXIII

Matecumbe Key sheepswool sponge. Natural size. 
IIX) = $=15$

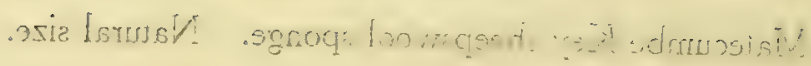




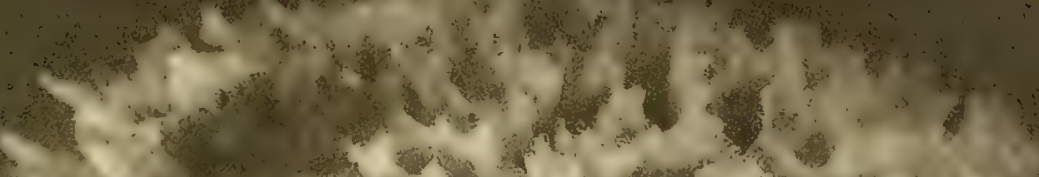

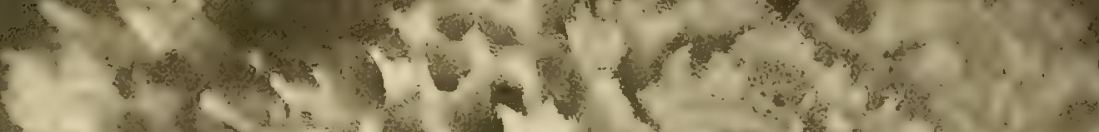

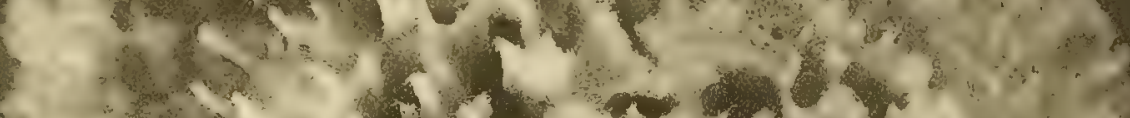

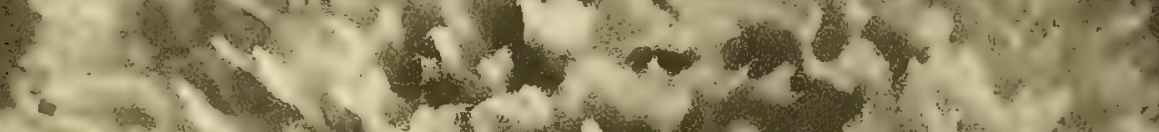

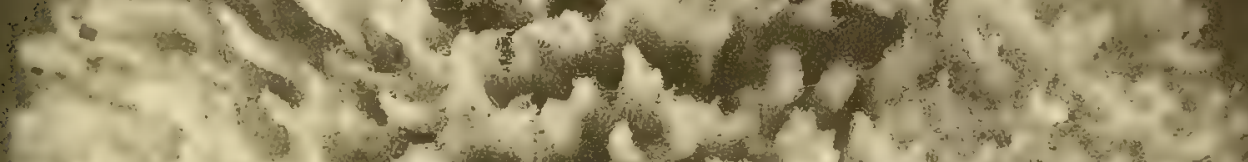

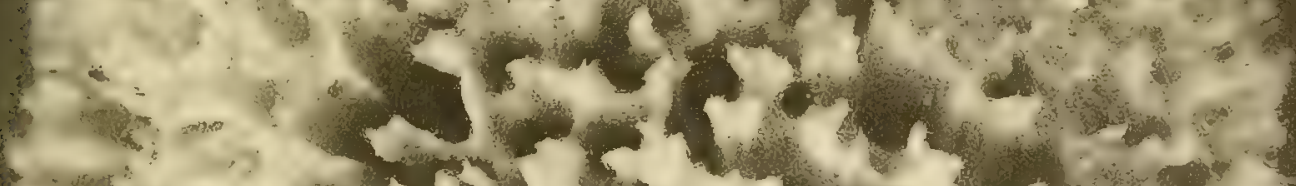
and

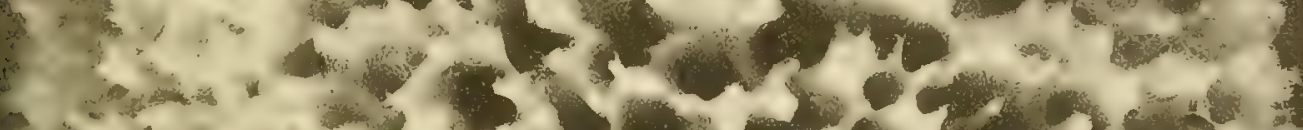

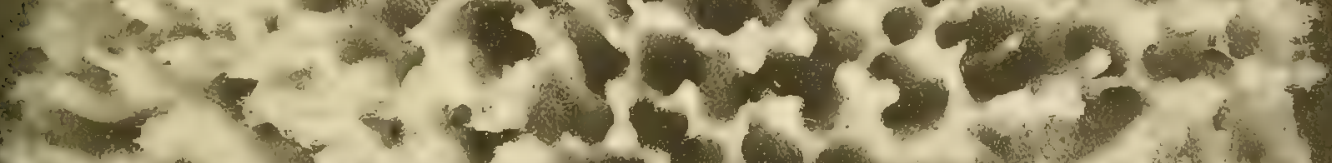
(n)

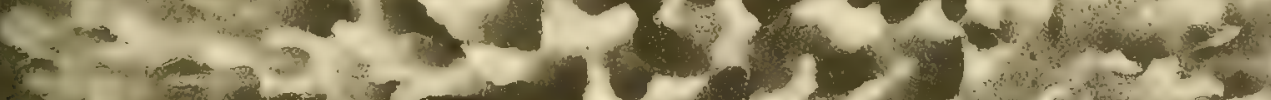
(2)

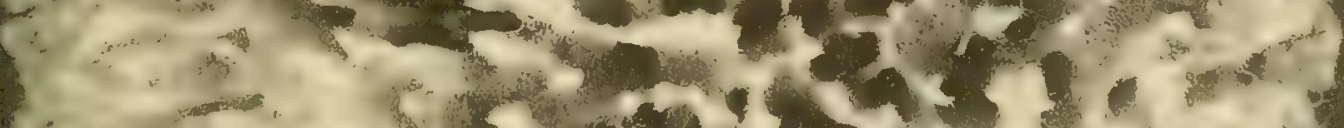

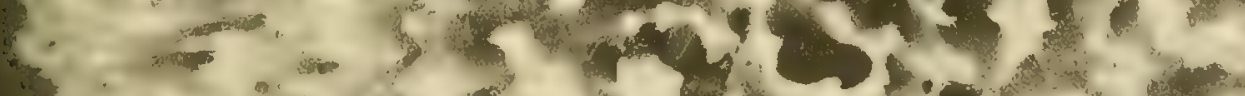

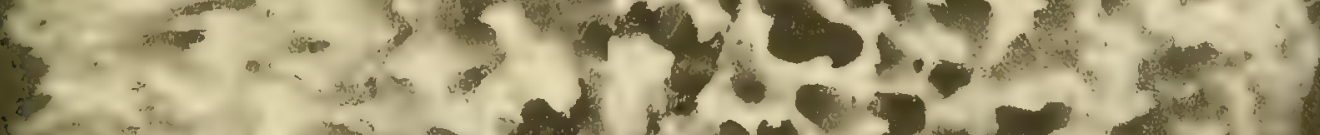

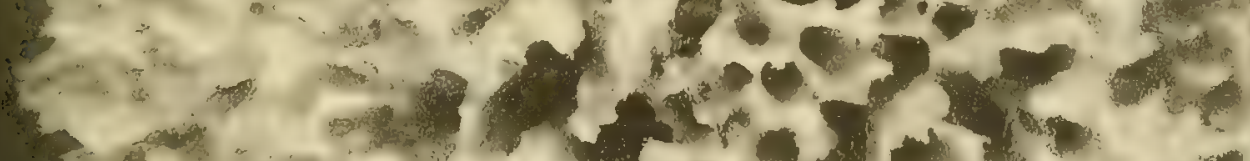
and atrate?

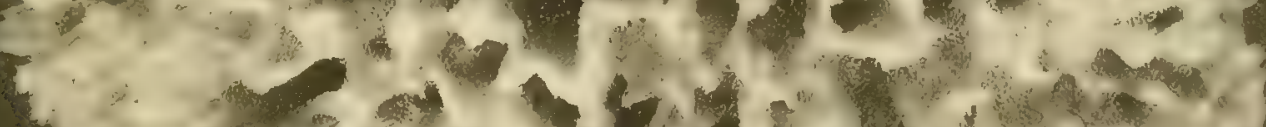

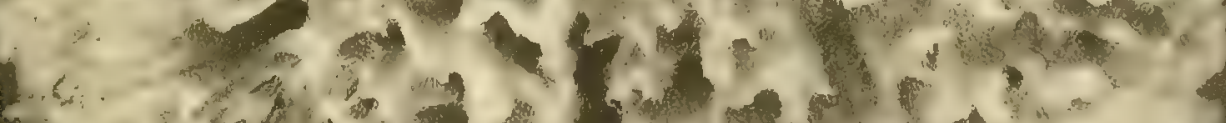

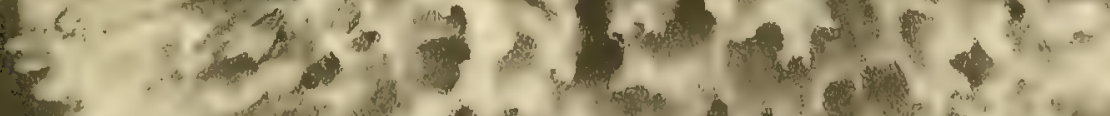

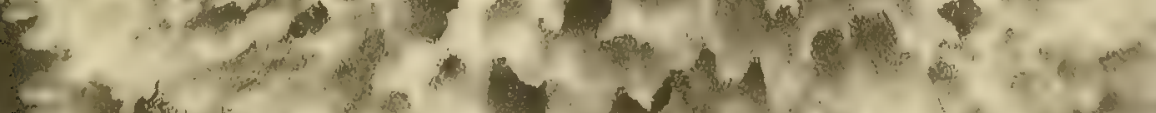
$2 x-3 x^{2}+e^{2} \cdot 5$

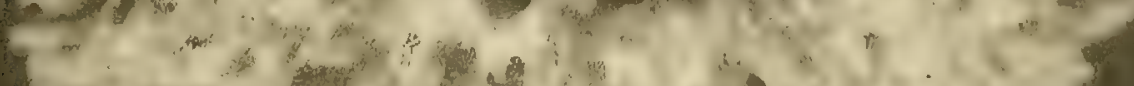

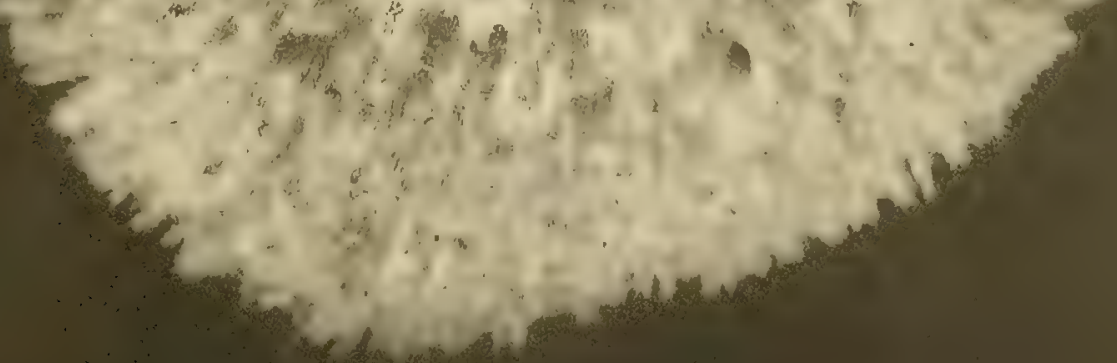





\section{Plate XXXIV}

Nassau sheepswool sponge, Bahama Islands. Natural size. 
VIXXK 91619

.9siz ! 


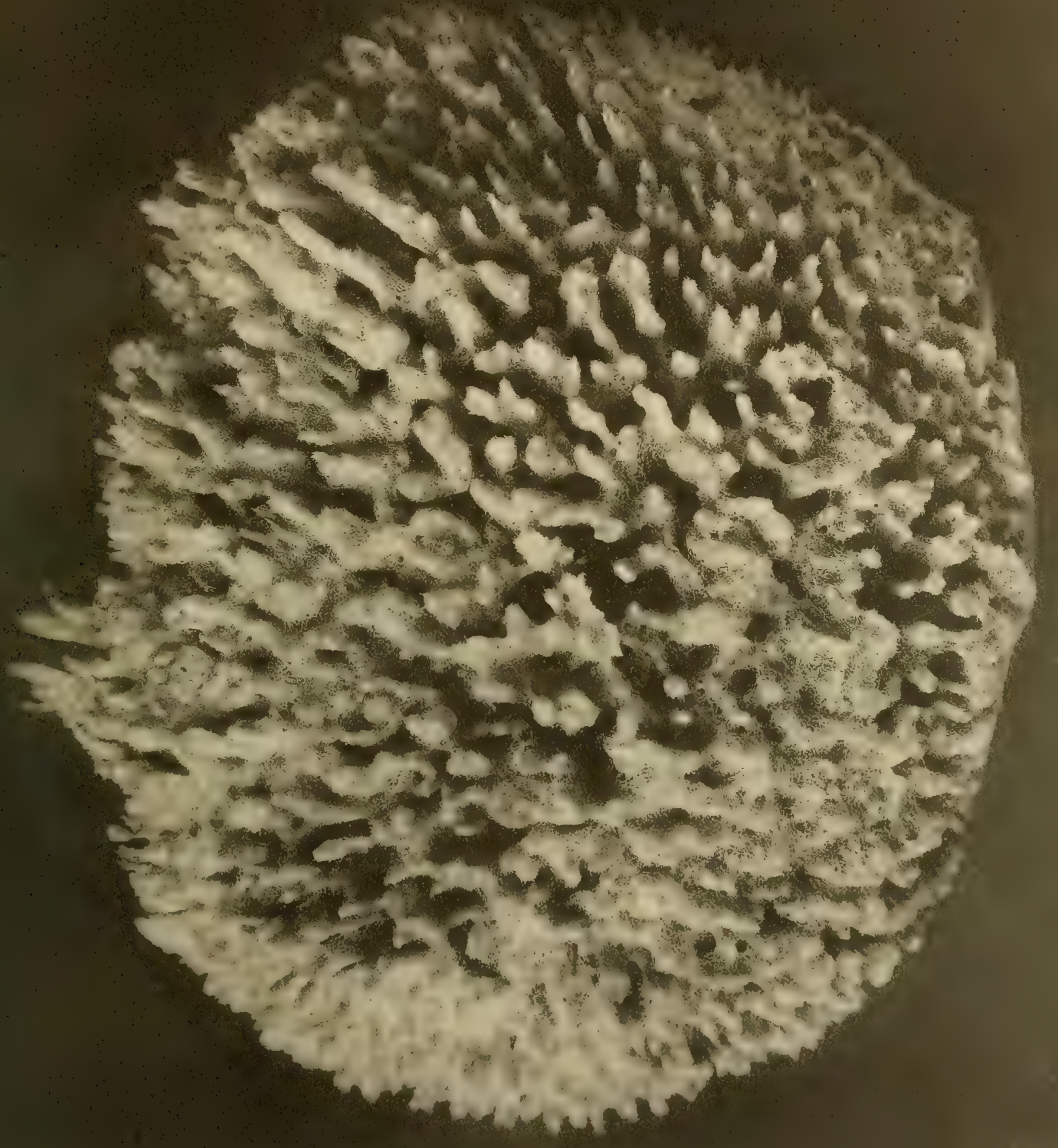





\section{Plate XXXV}

Abaco sheepswool sponge, Bahama Islands. Natural size. 
VXXX 91519

.9sia I 


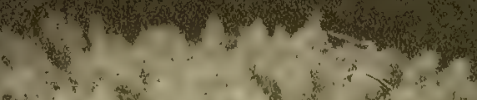

(2)

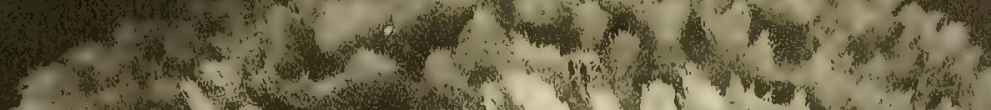

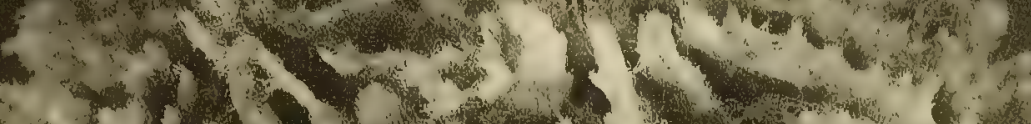

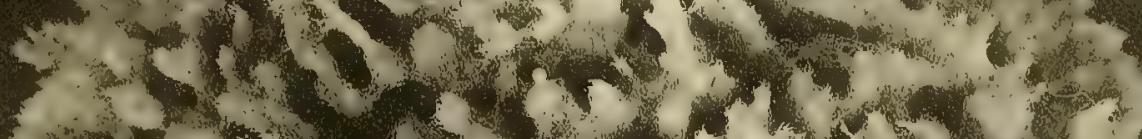

F

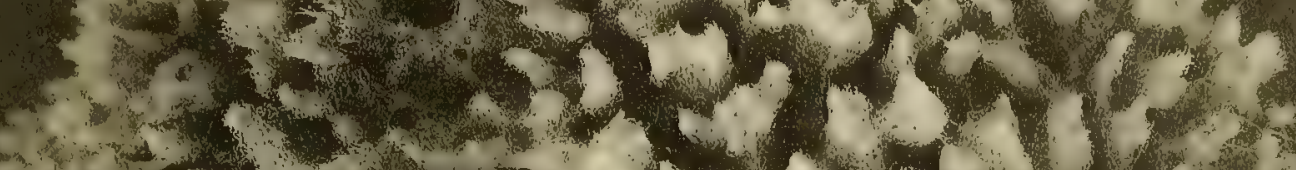

C. 1.

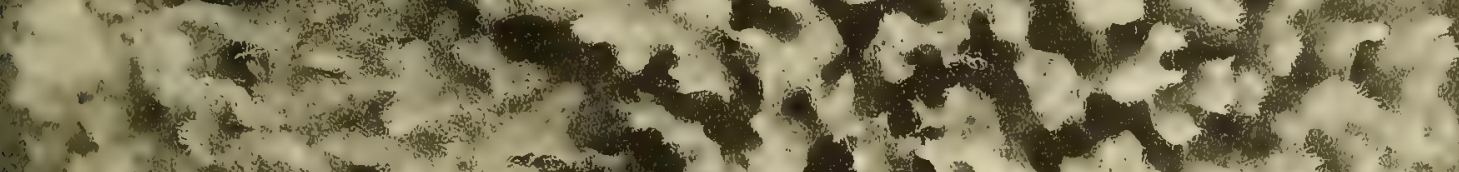

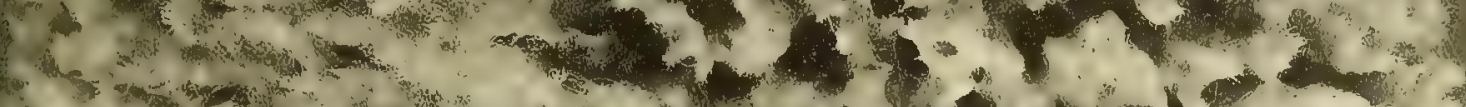

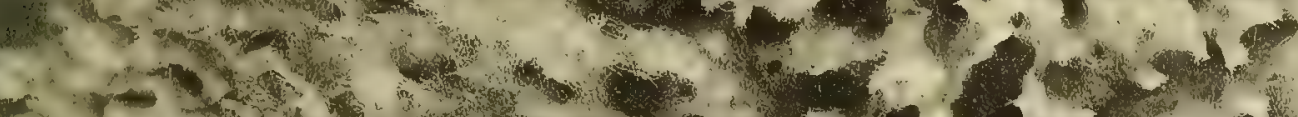

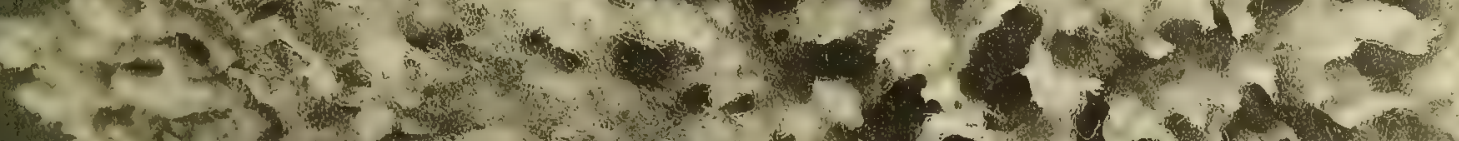

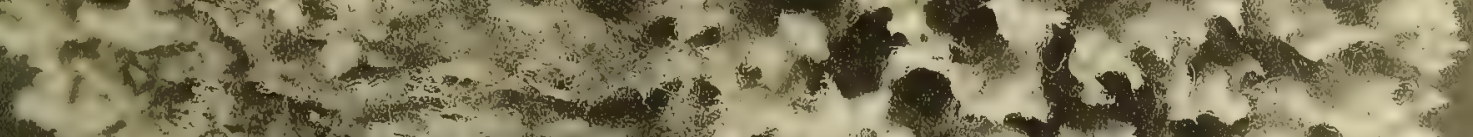

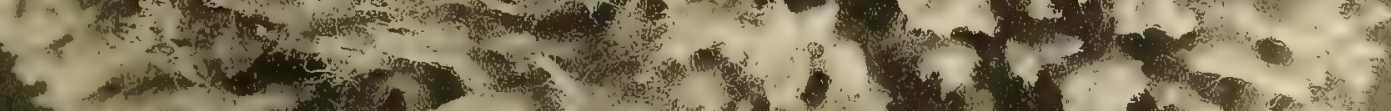

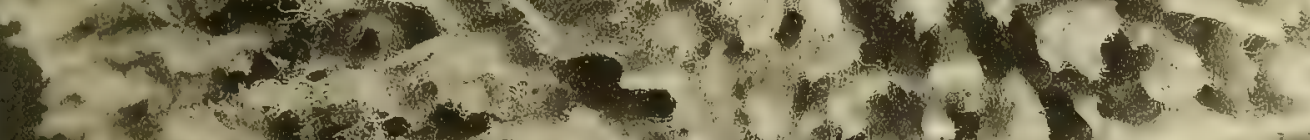

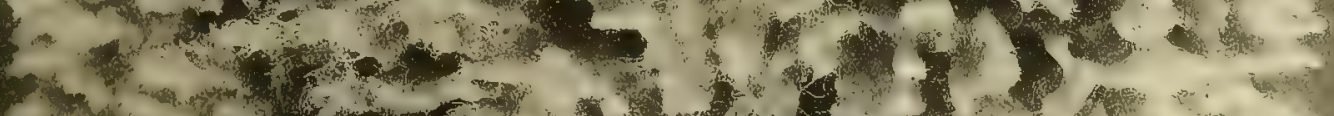
Pat

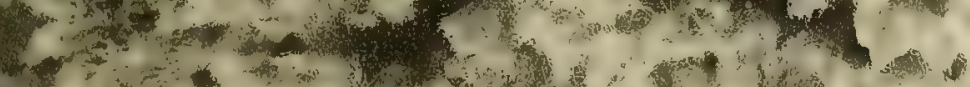

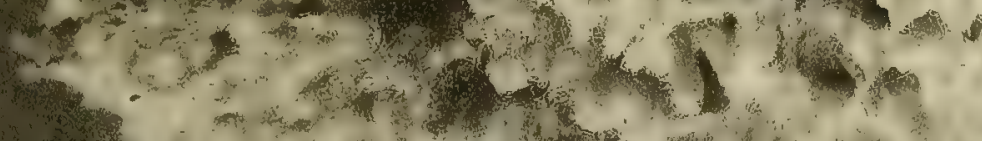

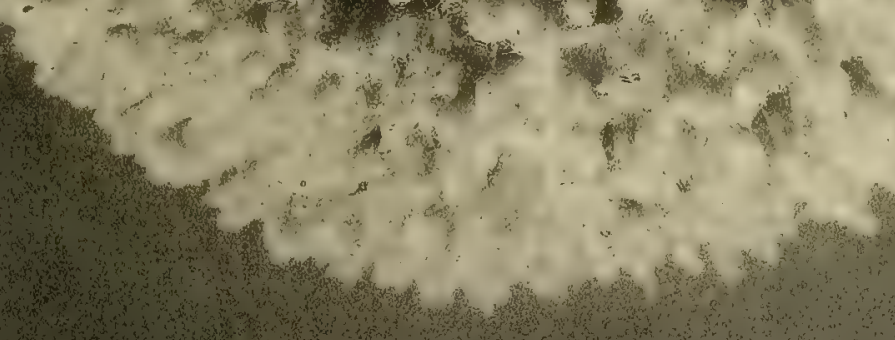



Plate XXXVI

Cuba sheepswool sponge. Natural size. 
I $K X X$ 9

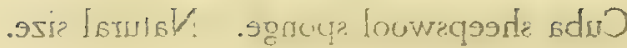


1.1

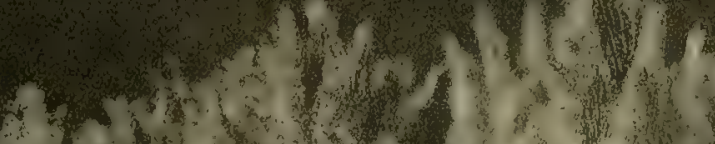

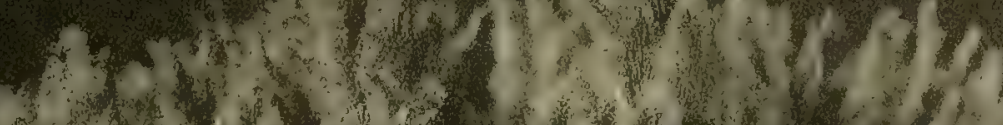

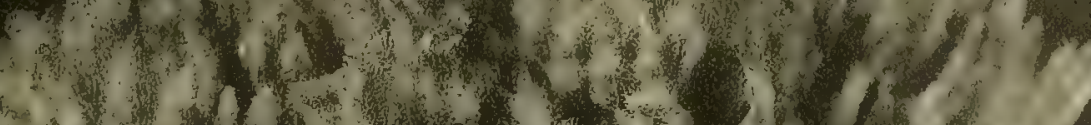

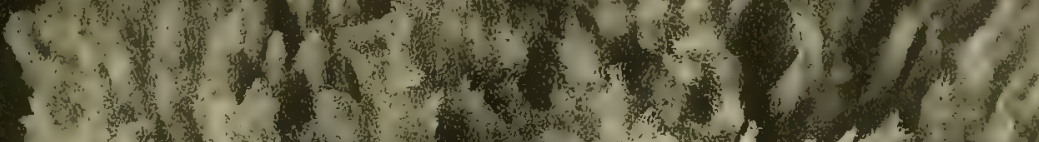

(6)

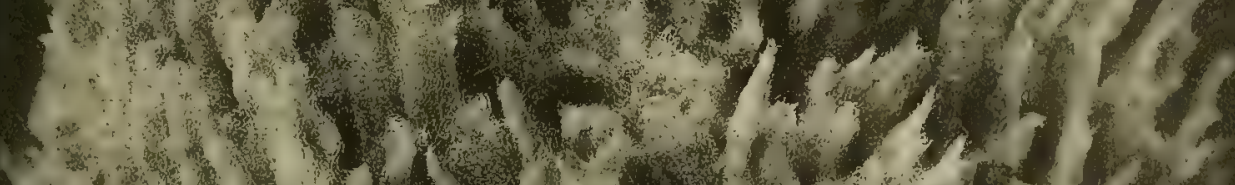

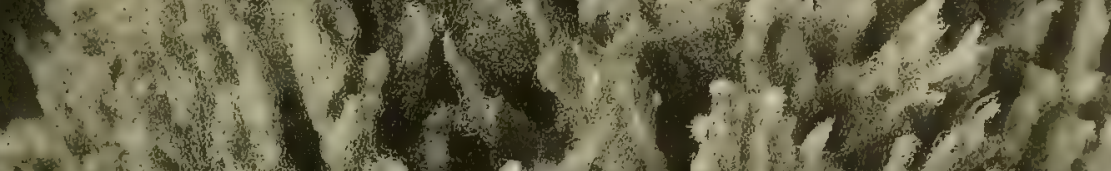

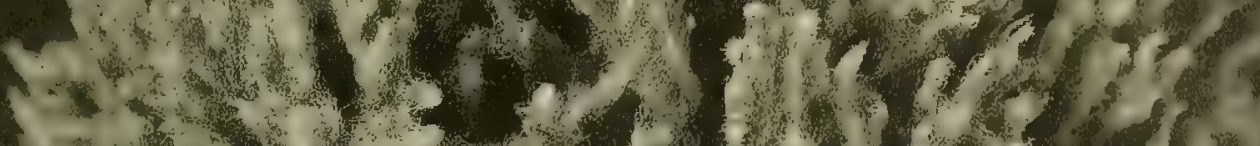

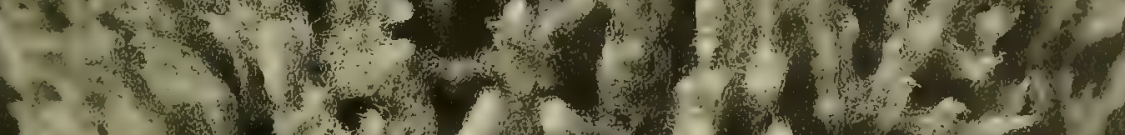

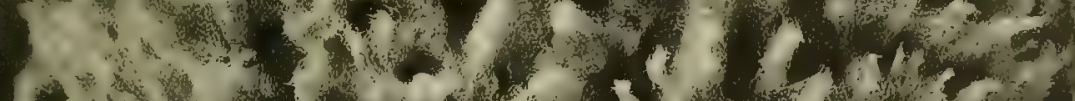

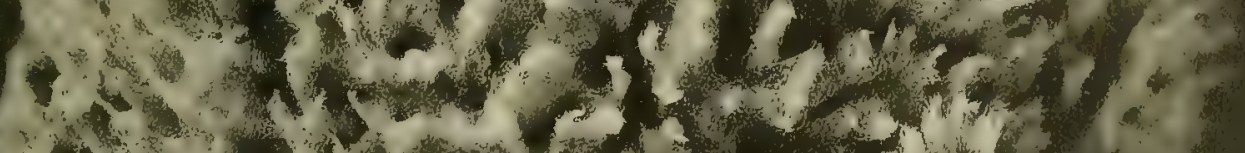
1.

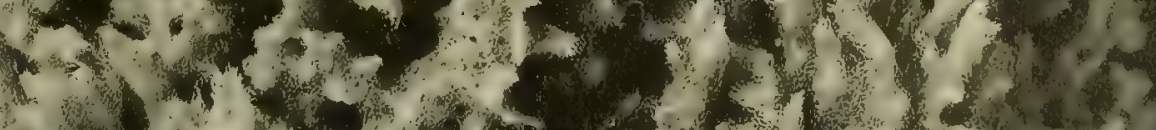
(1) C. 1.4.

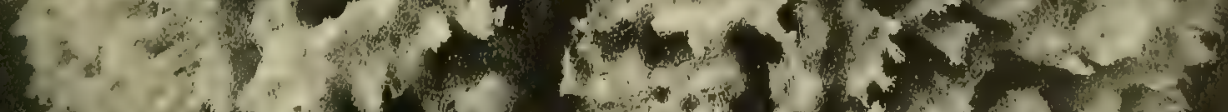

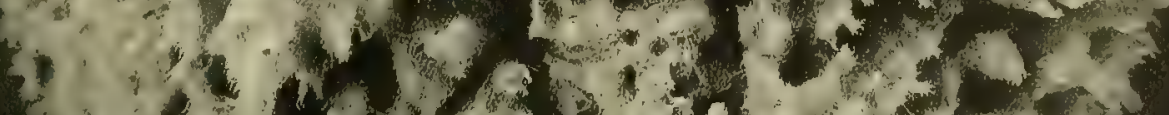

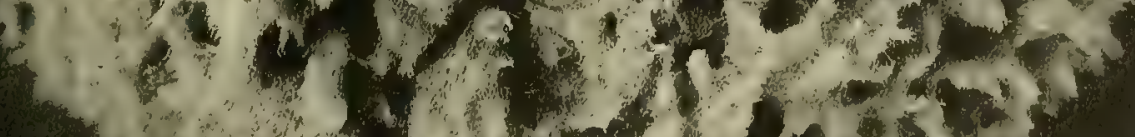

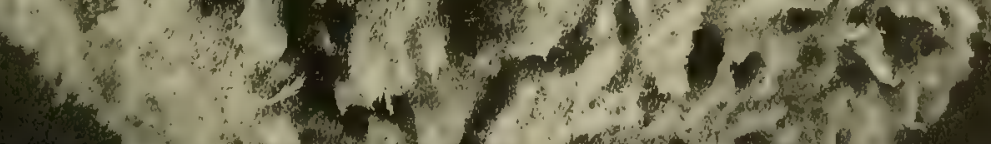

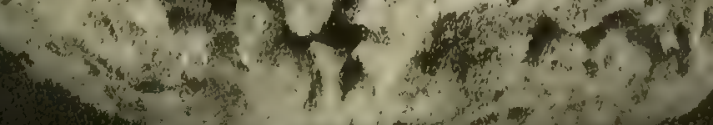





\section{Plate XXXVII}

Florida Key yellow sponge. Natural size. 
IIVTXX 915'9

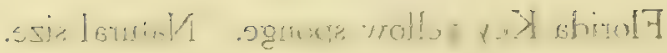




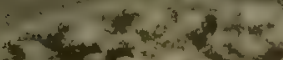

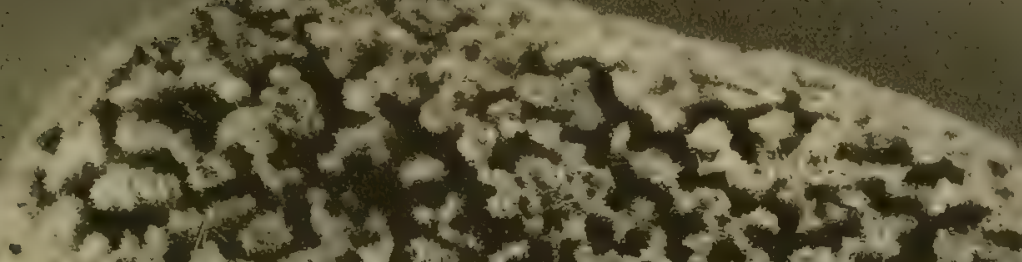

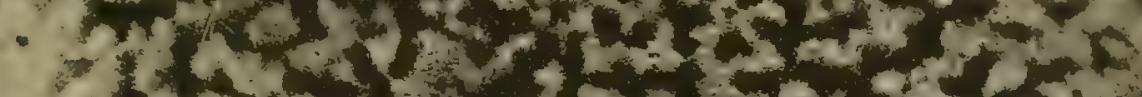

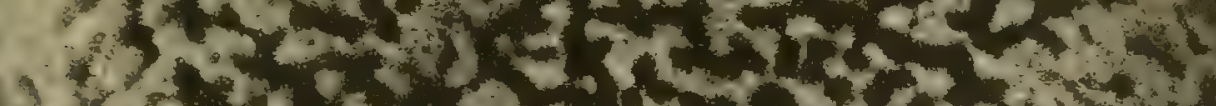

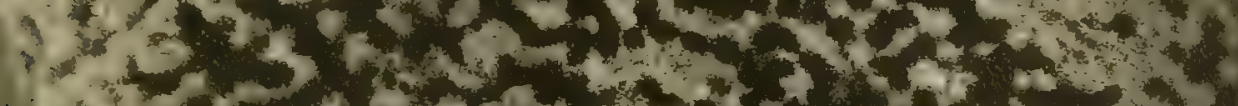

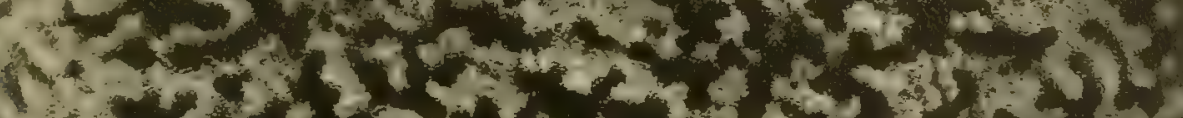

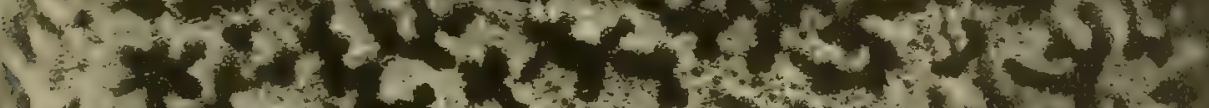

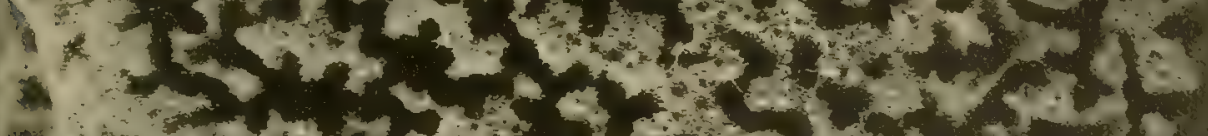
1

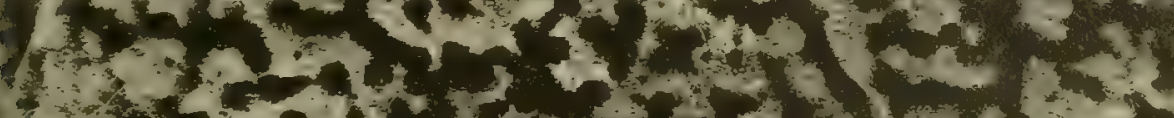
$107 x+2=10$

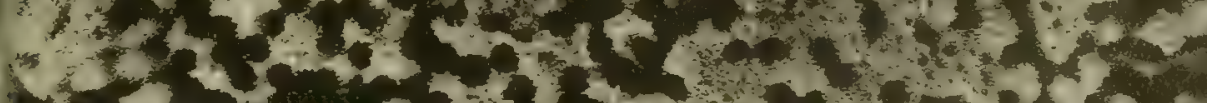

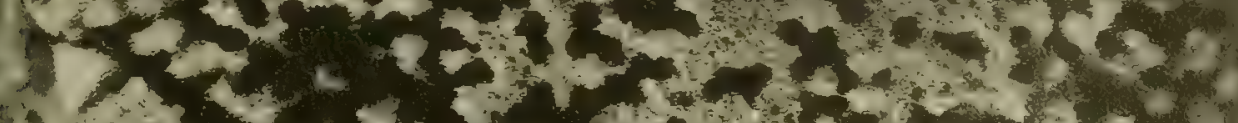

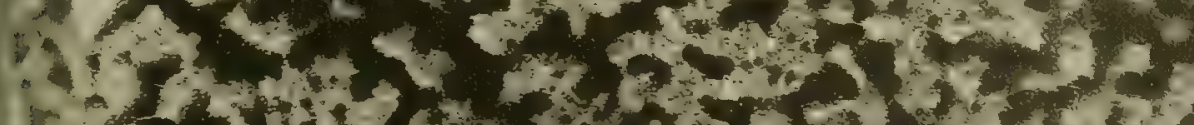

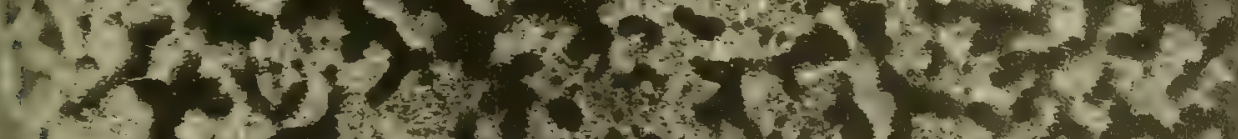

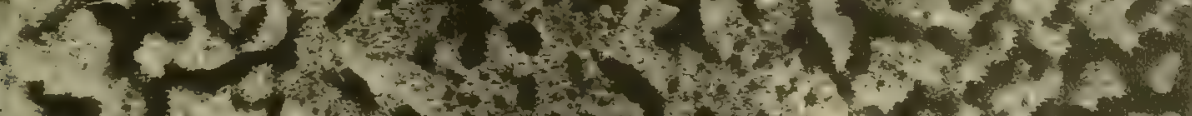

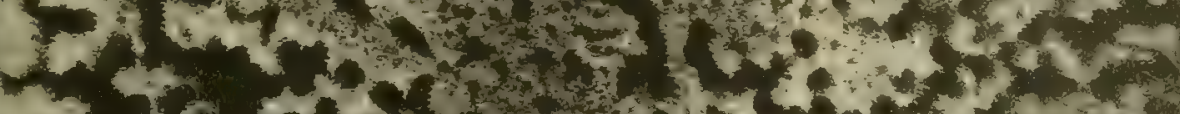
(1) (1) Noratizest.

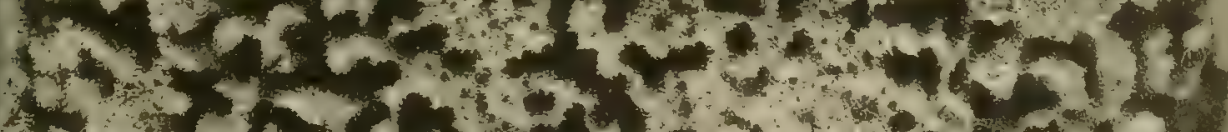
- Jarax

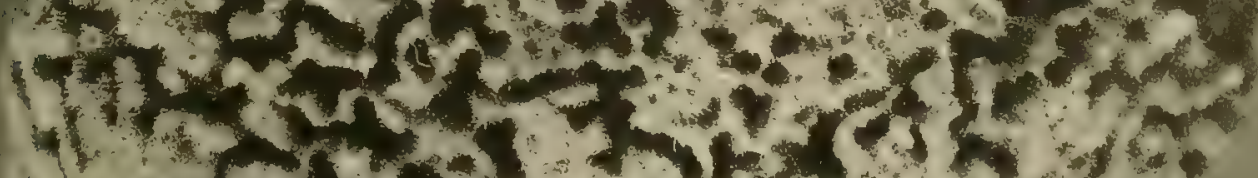

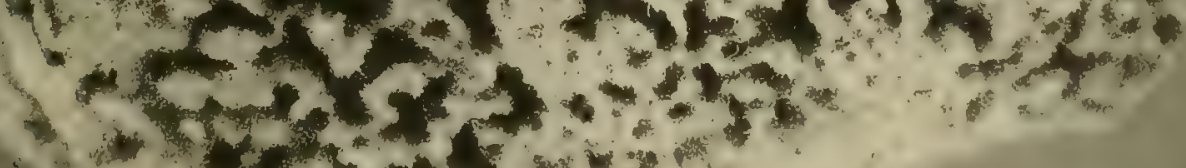
- textring 

Plate XXXVIII

Florida Key yellow sponge, top view. Natural size. 
IIIVXXX 3rid

. vie I fruis 


Plate XXXIX

Florida Key yellow sponge. Natural size. 


$$
71 \%, \ldots=19
$$

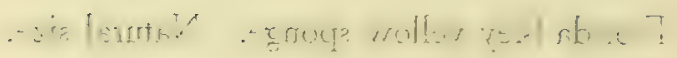




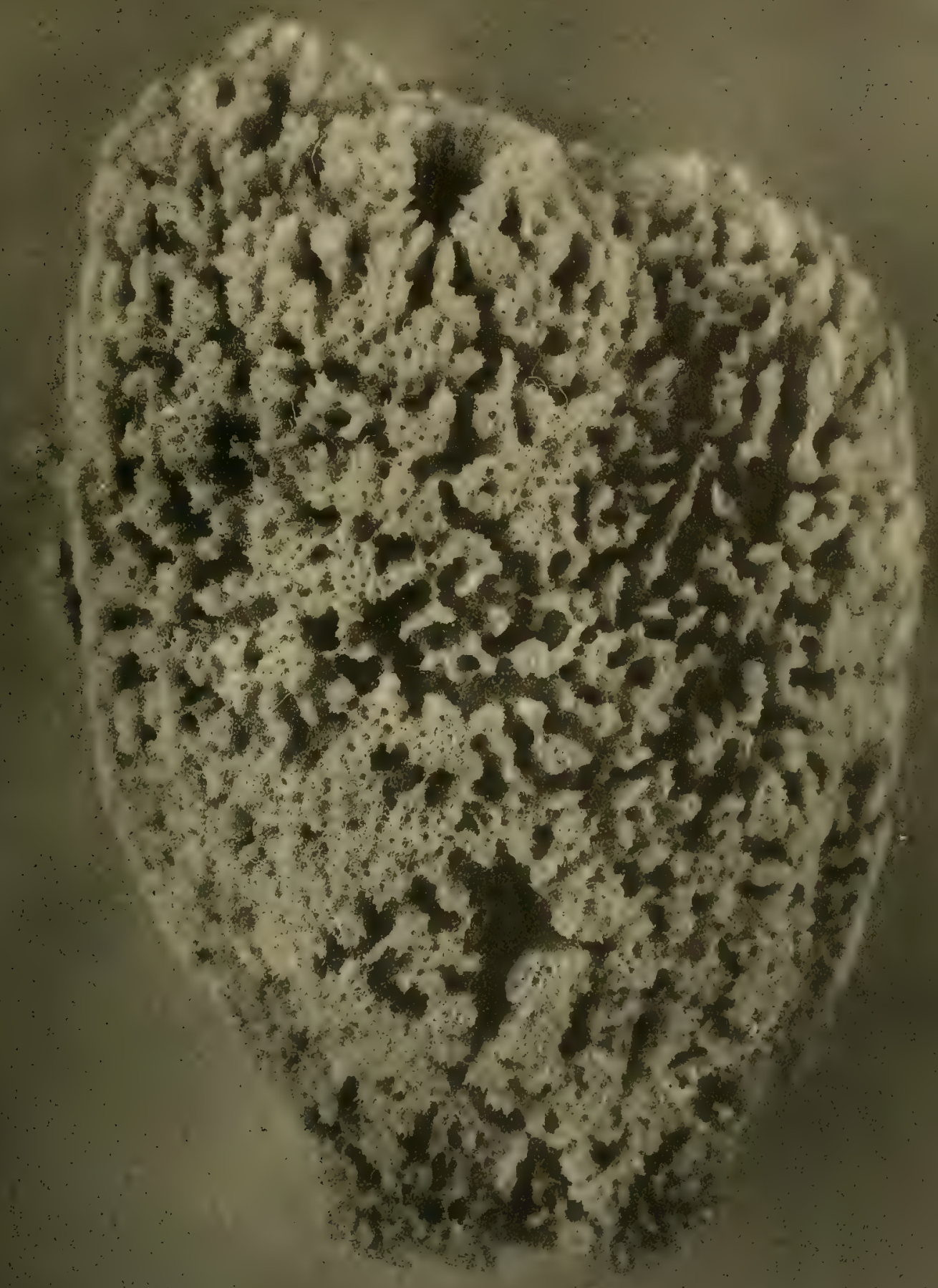



Plate XL

Anclote yellow sponge. Natural size. 
IY.

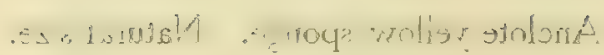




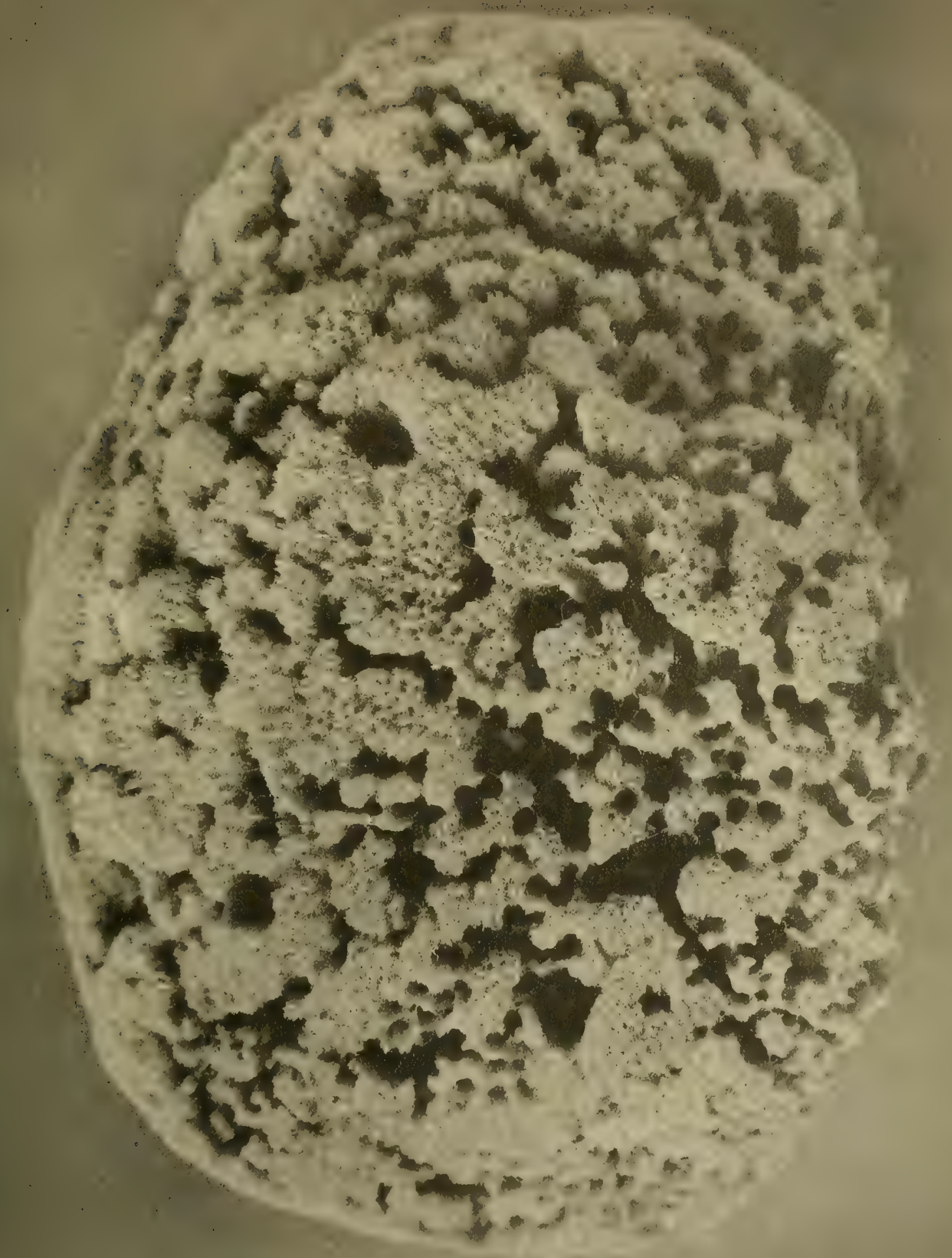





\section{Plate XLI}

Anclote yellow sponge. Natural size. 
IIX जब

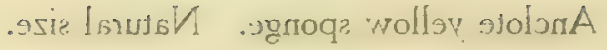




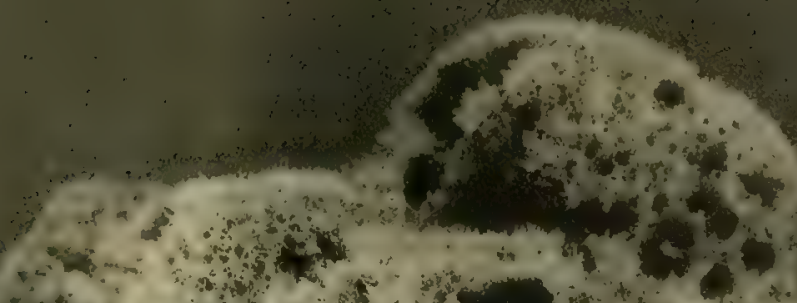
and

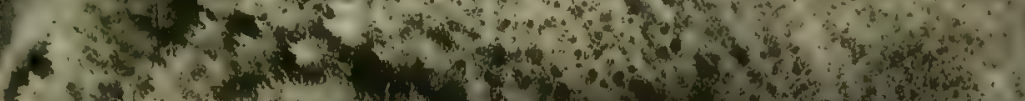

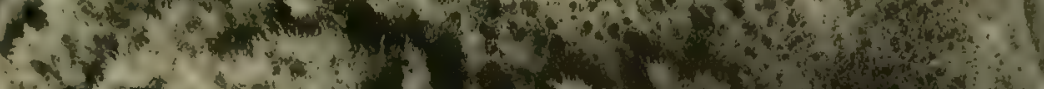

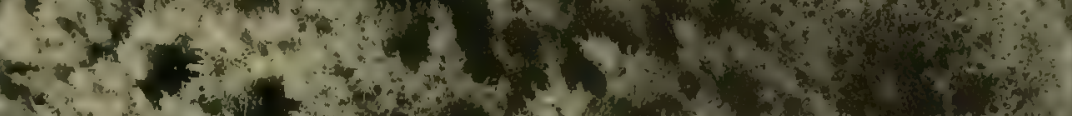

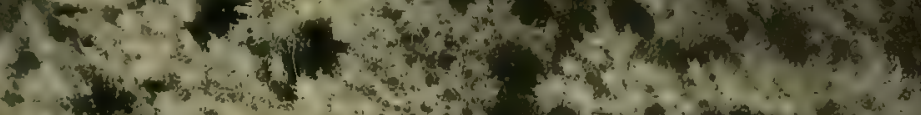

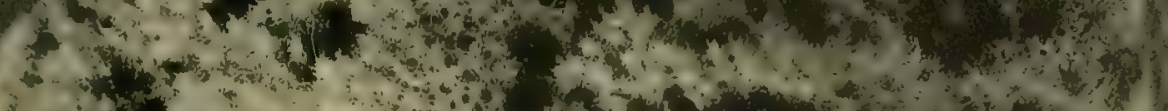

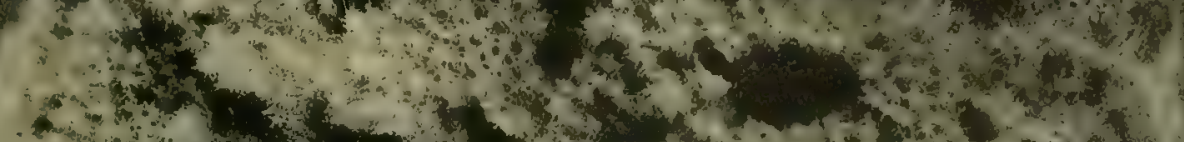

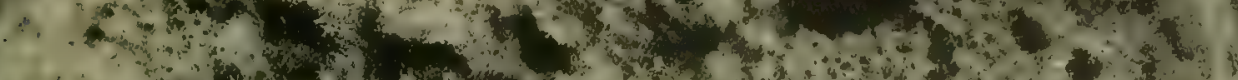

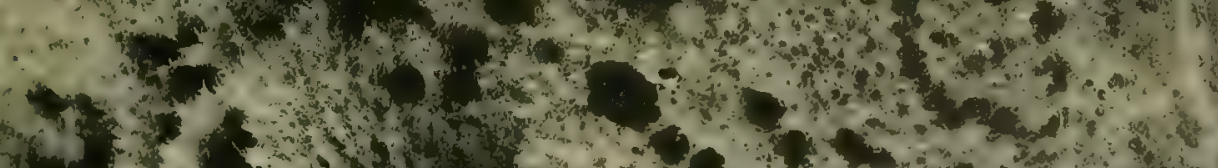

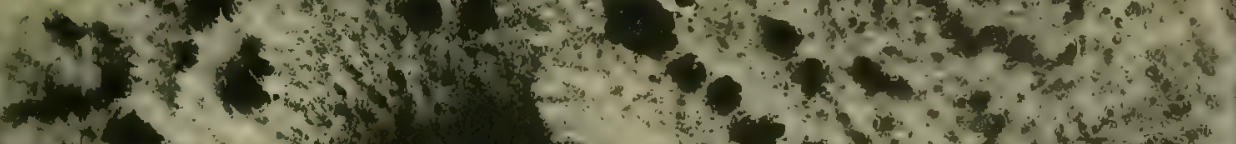

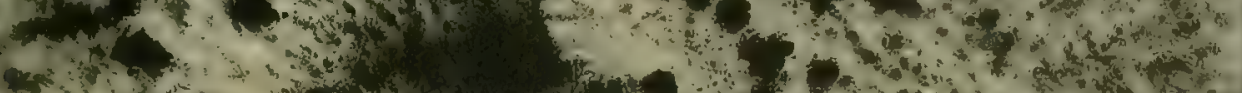

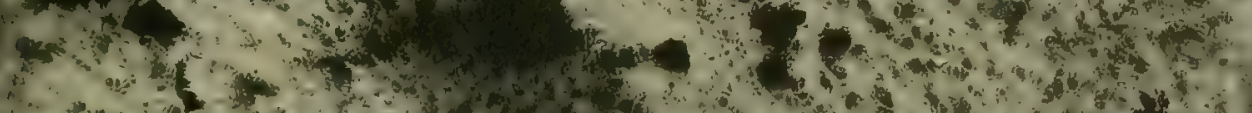

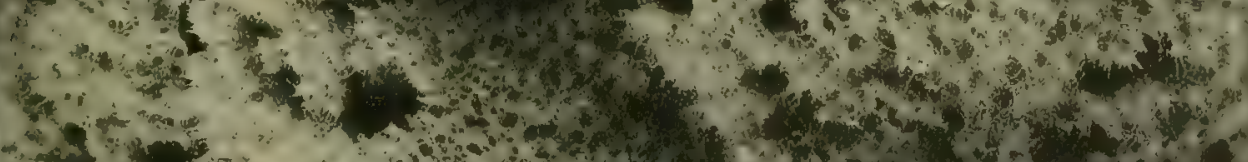

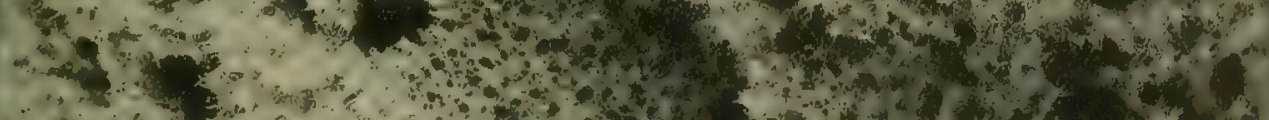

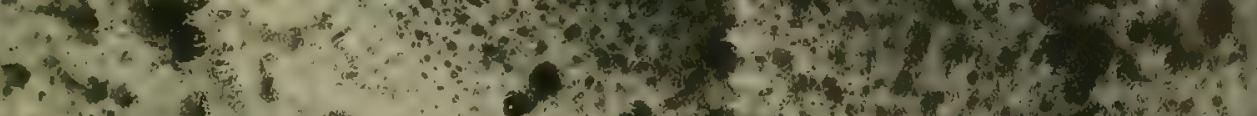

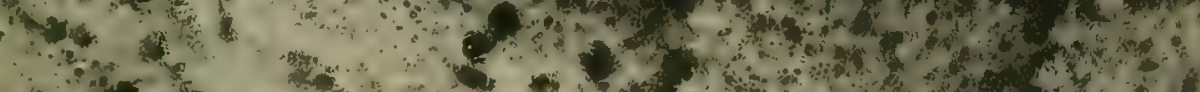

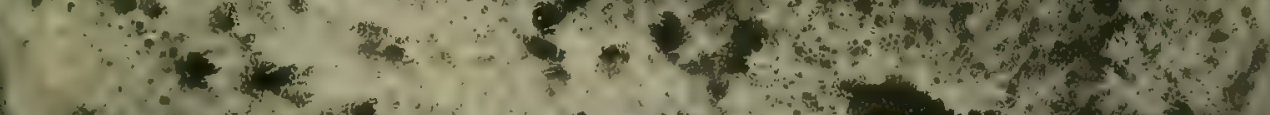

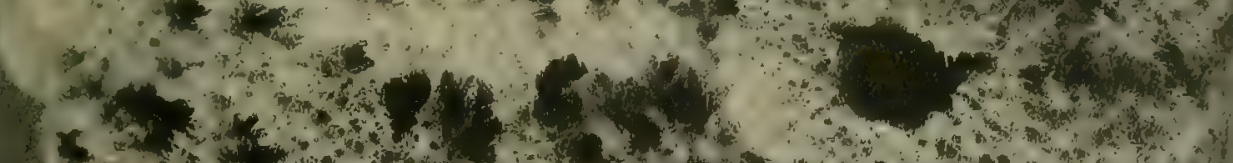

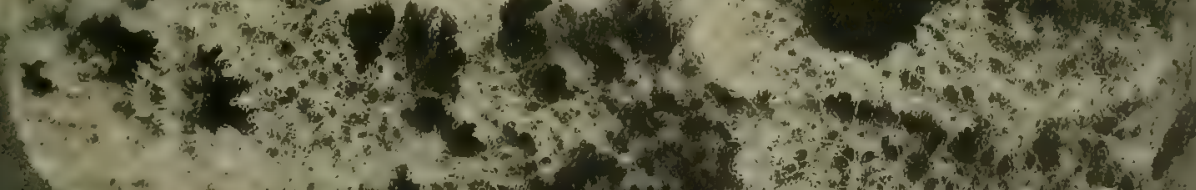
(10. 

Plate XLII

Bahama yellow sponge. Natural size. 
II.TX 91619

ssie I 


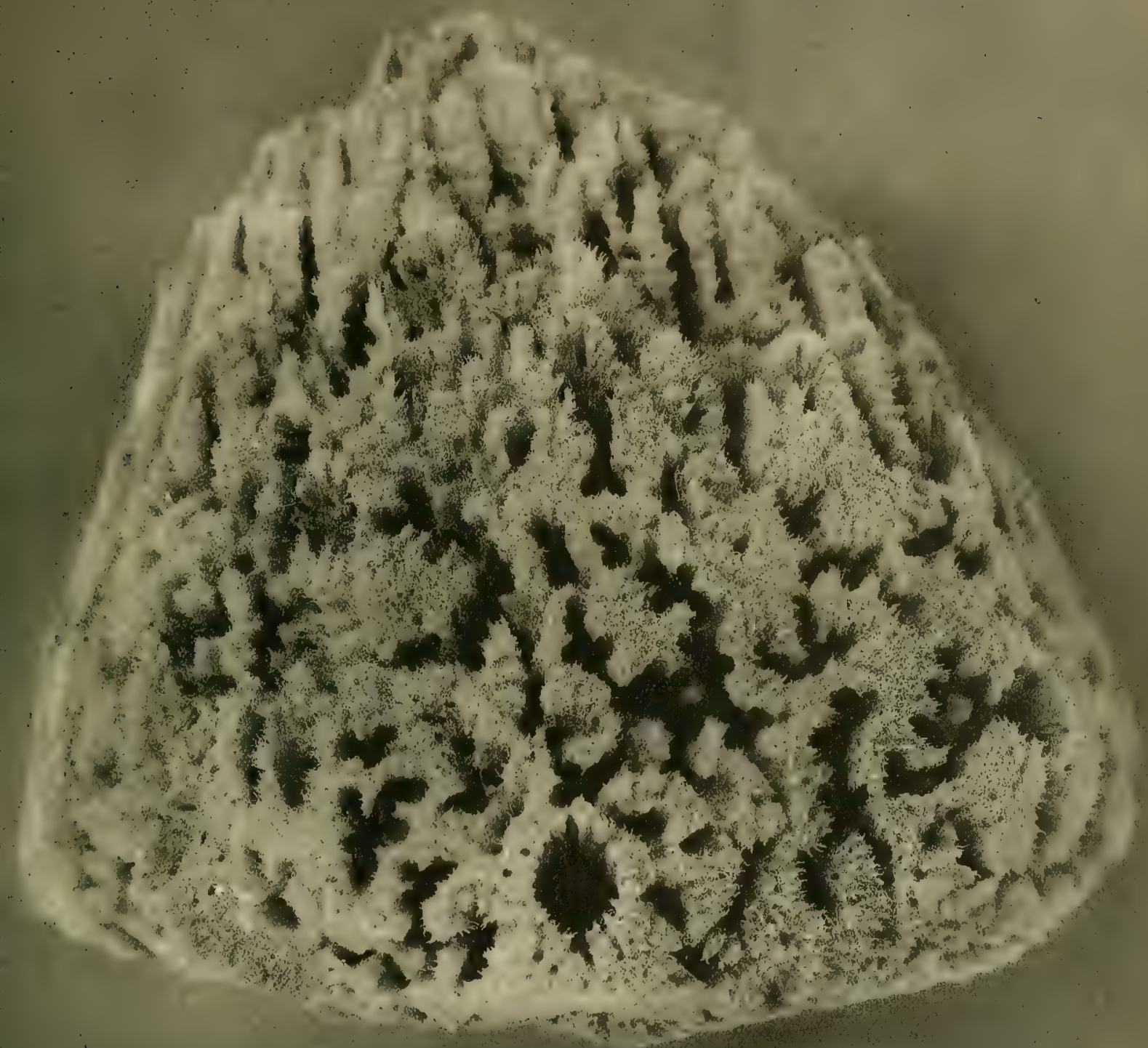





\section{Plate XLIII}

Bahama yellow sponge. Natural size. 
MLIX IST $^{-19}$

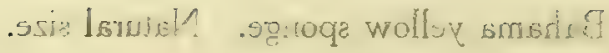




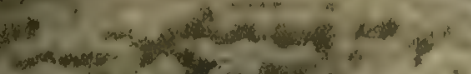

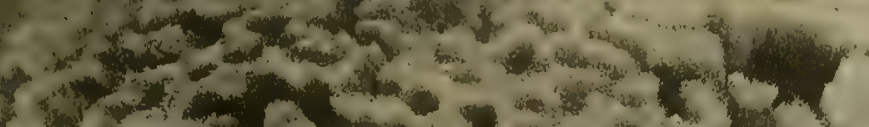 \\ (2.}

$4026+5+2+213$

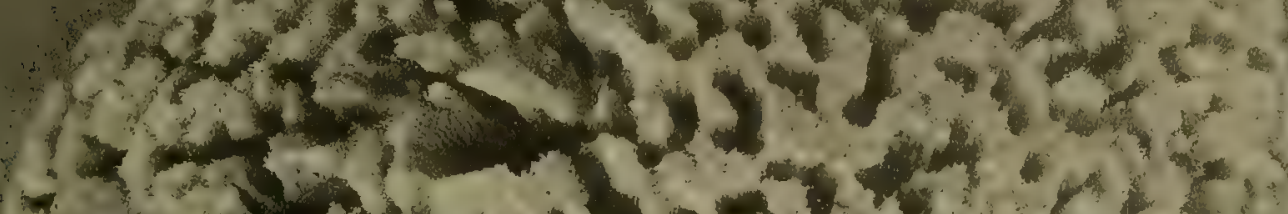

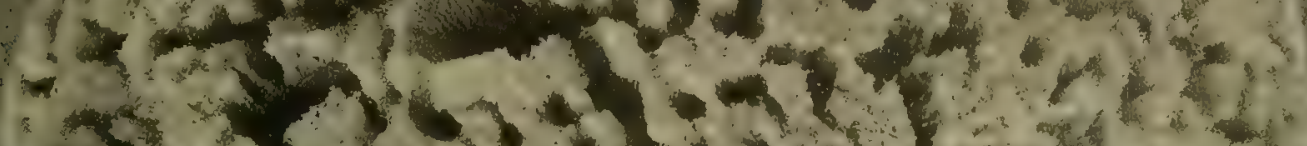

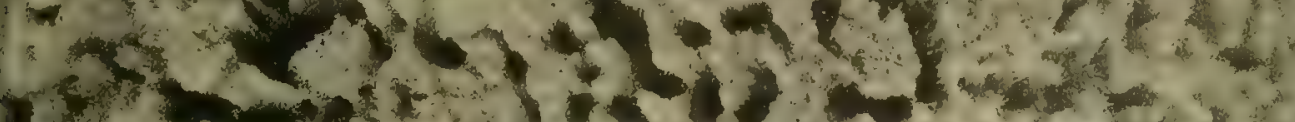

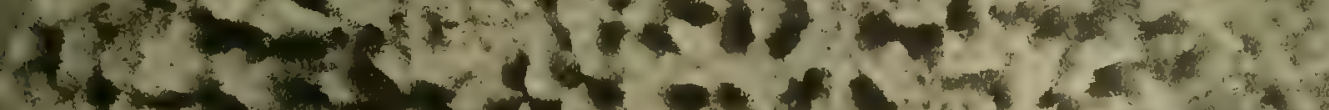

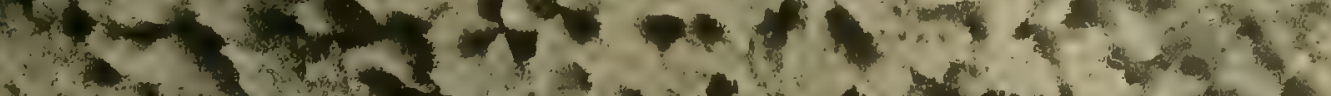

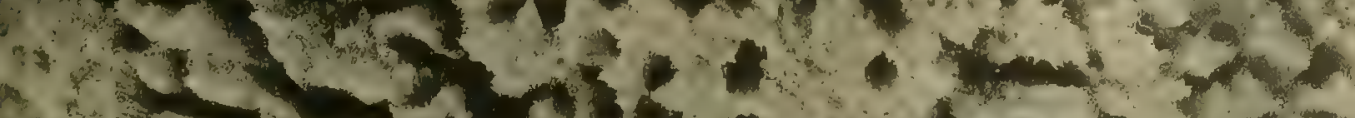

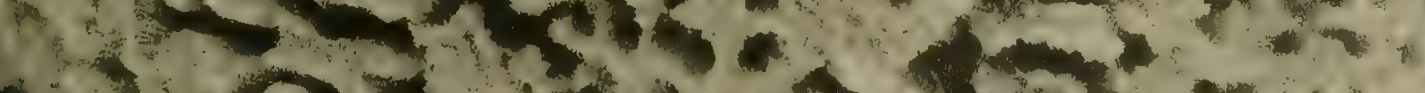

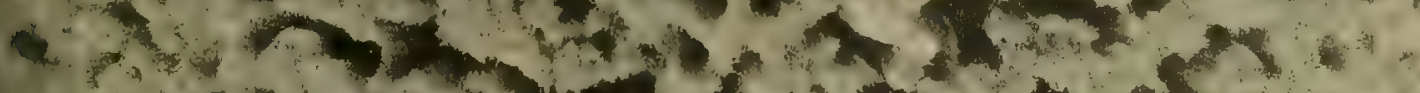

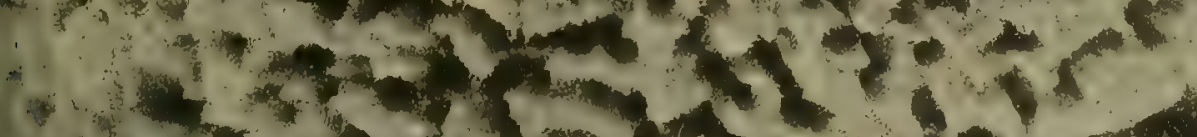

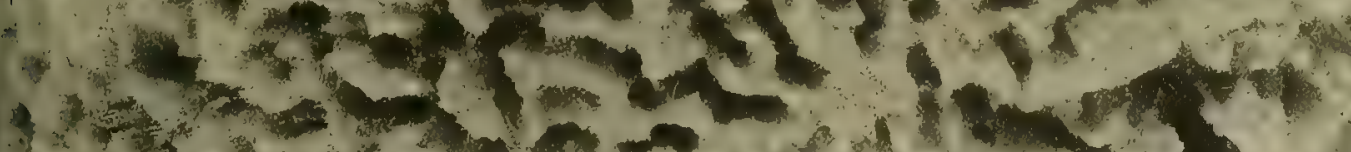

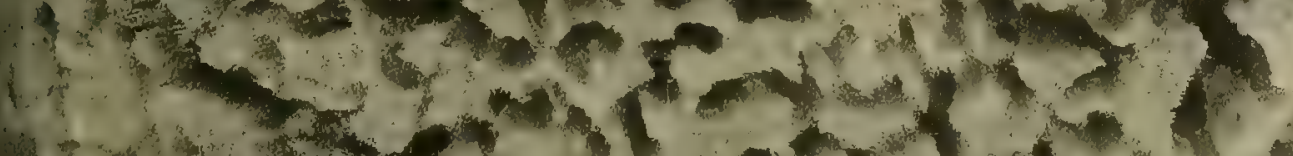

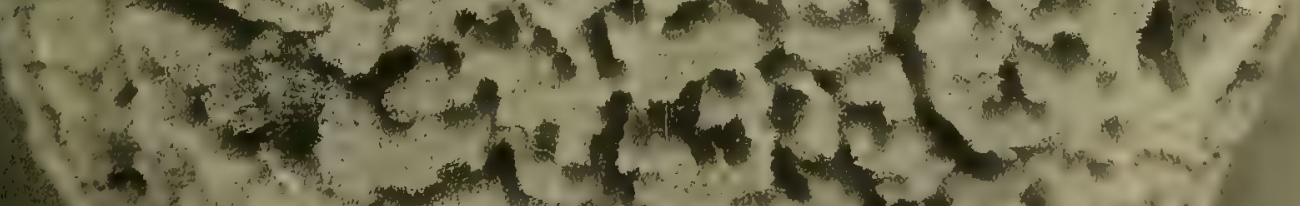

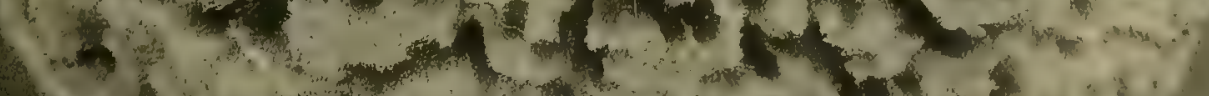

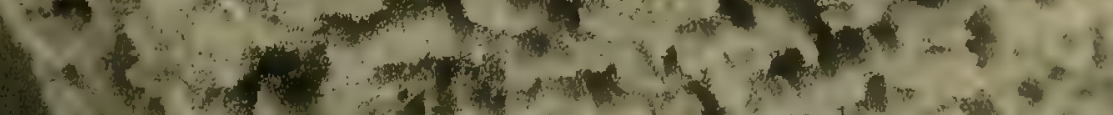

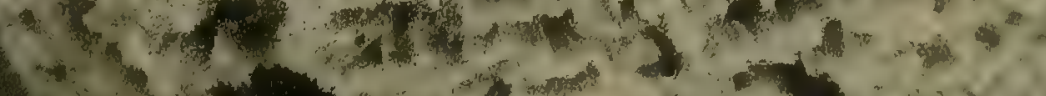

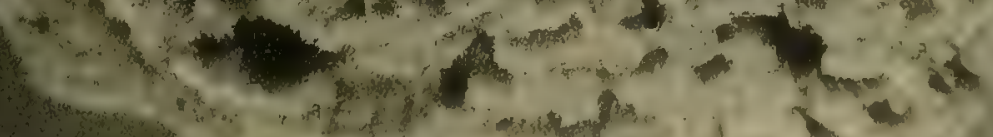
(5) 



\section{Plate XLIV}

Cuba yellow sponge. Natural size. 


$$
\text { VIIY. 9519 }
$$

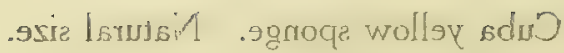




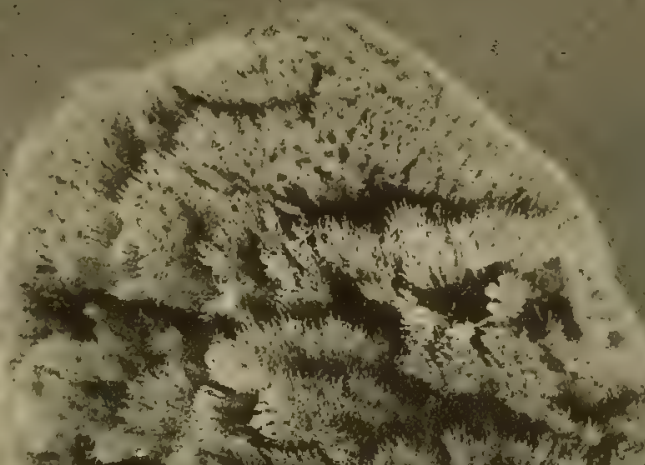

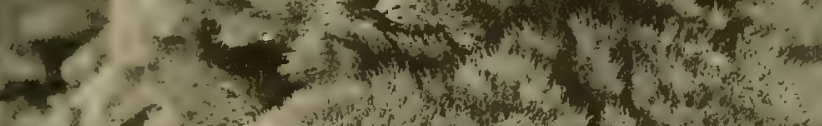
and

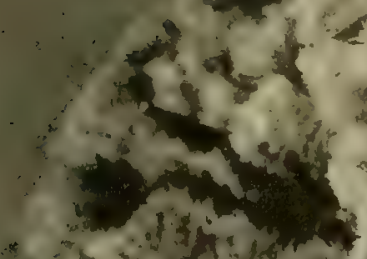

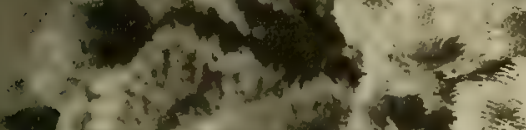

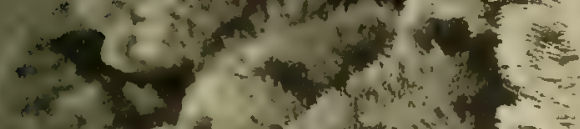

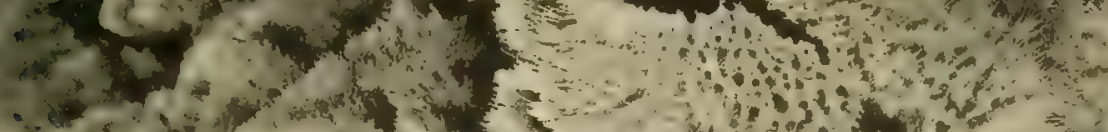

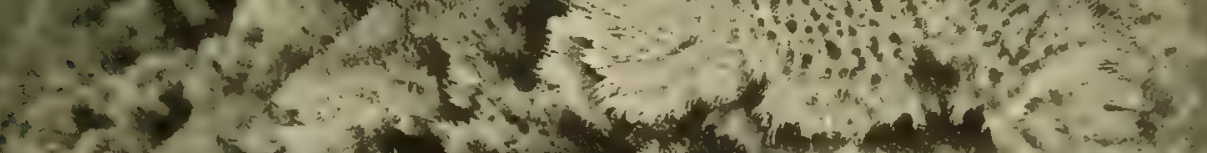

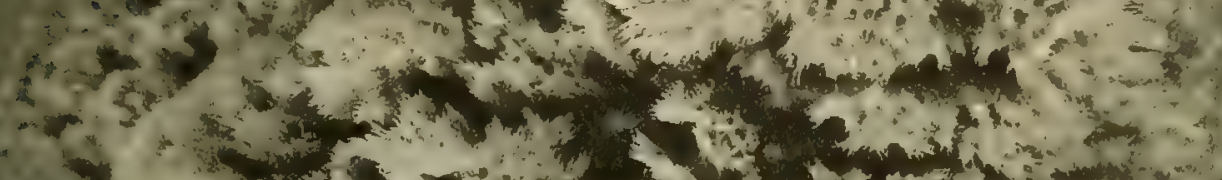

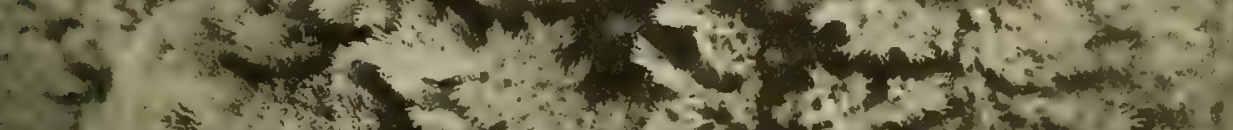

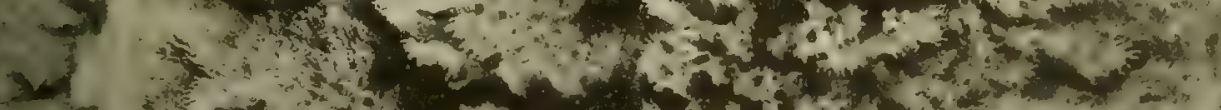

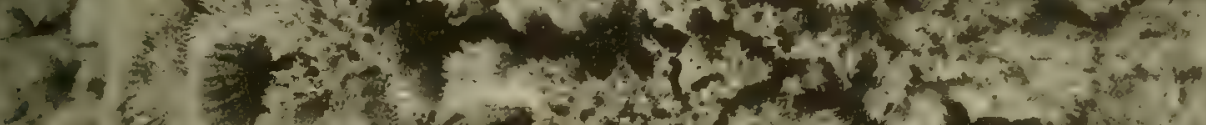

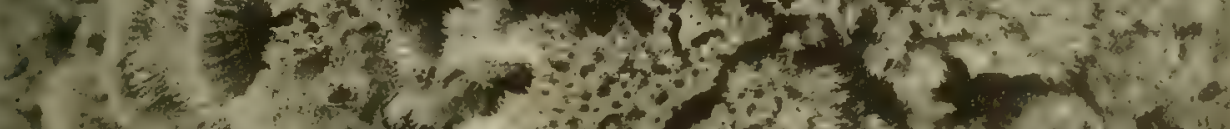

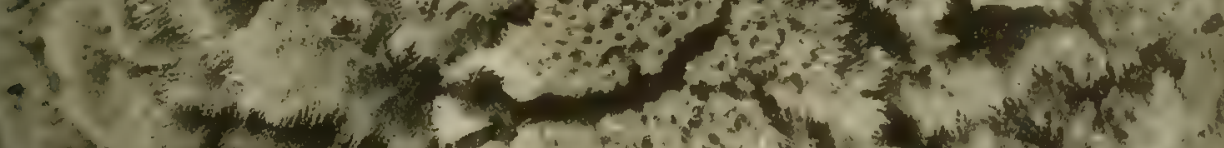
(n)

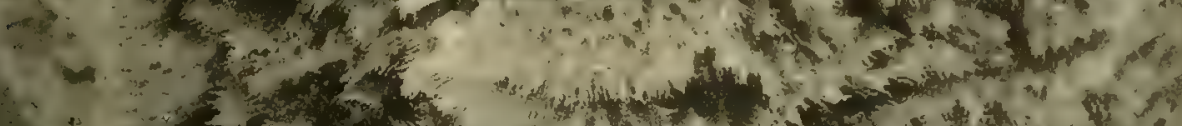

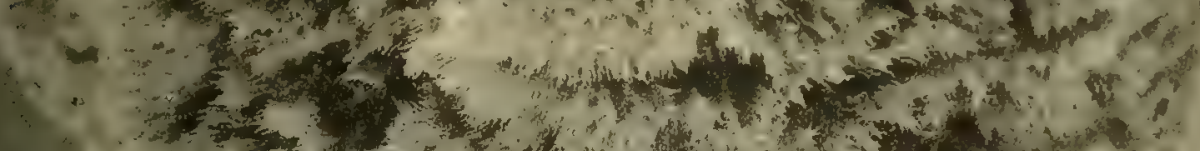

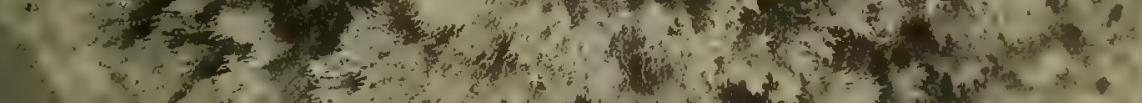

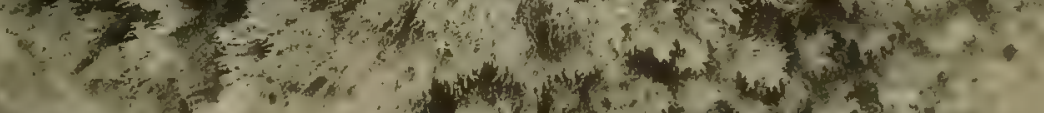

$$
\text { (1) }
$$





\section{Plate XLV}

Florida velvet sponge, top view. Natural size. 


$$
\text { V.IX } y_{6}[19
$$

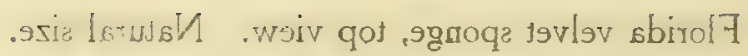




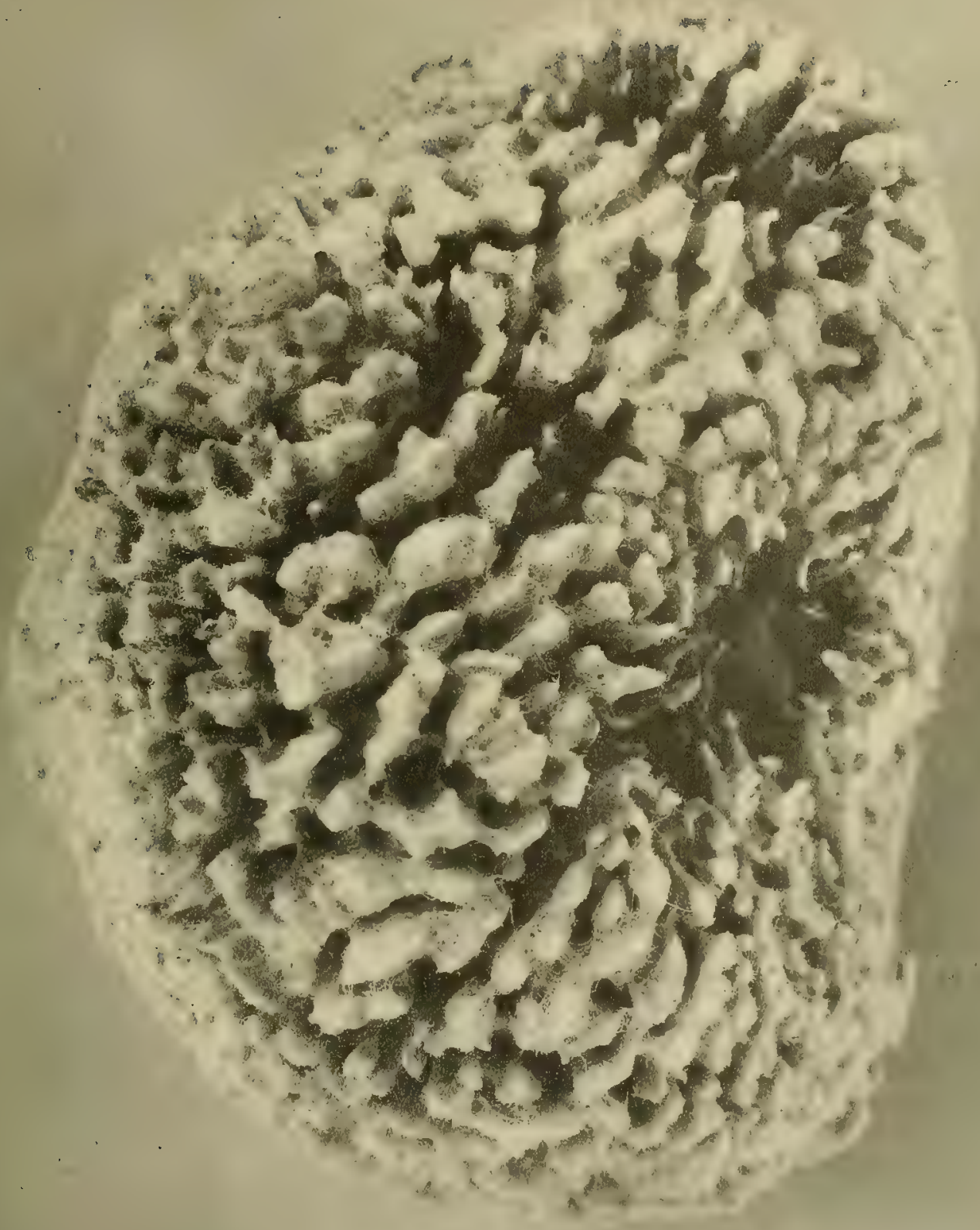





\section{Plate XLVI}

Bahama velvet sponge. Natural size. 
IV IY. 9isl9

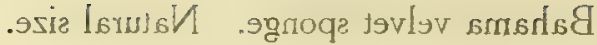




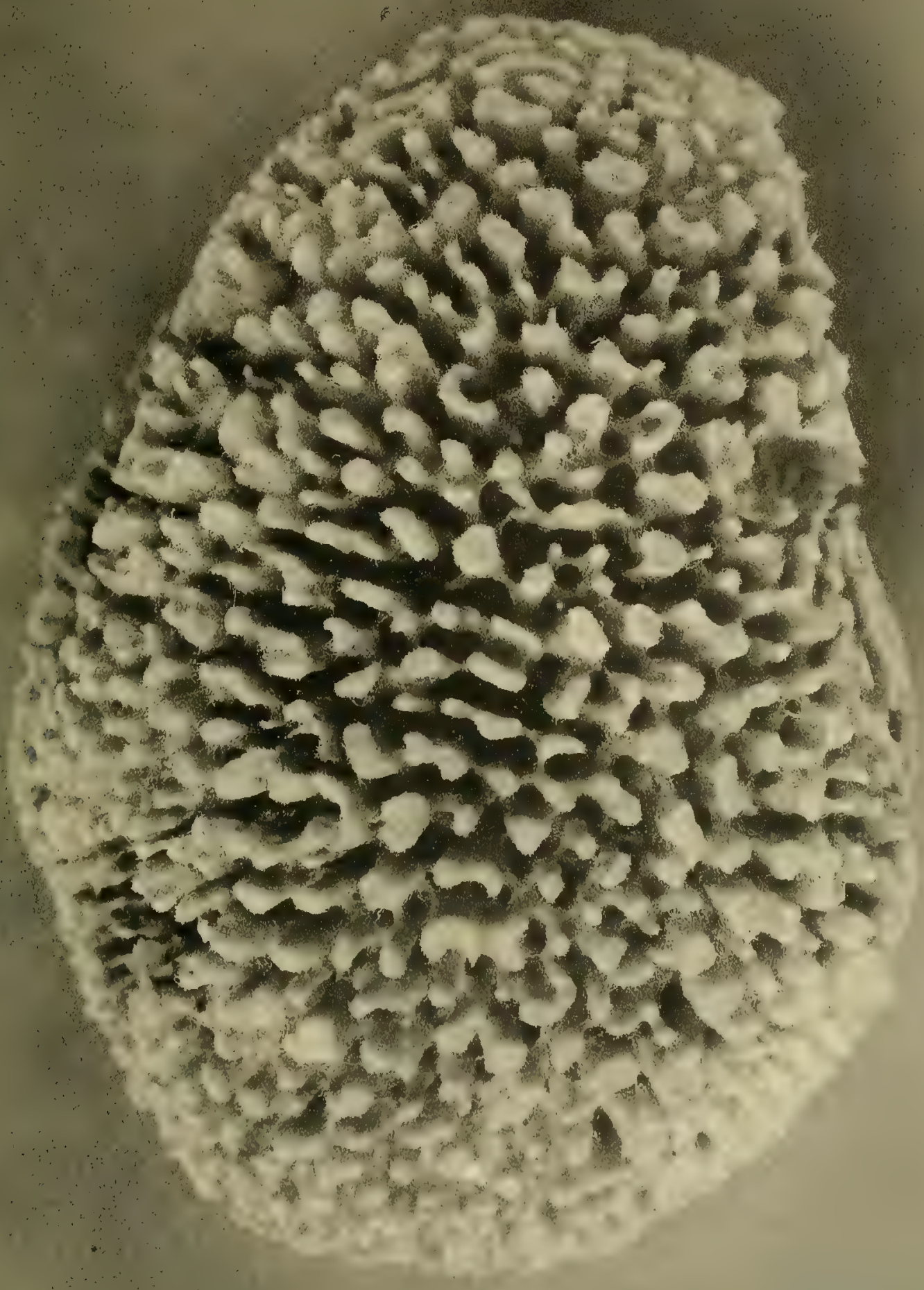





\section{Plate XLVII}

Cuba velvet sponge. Natural size. 
IIVIS ग. 1919

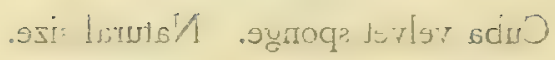




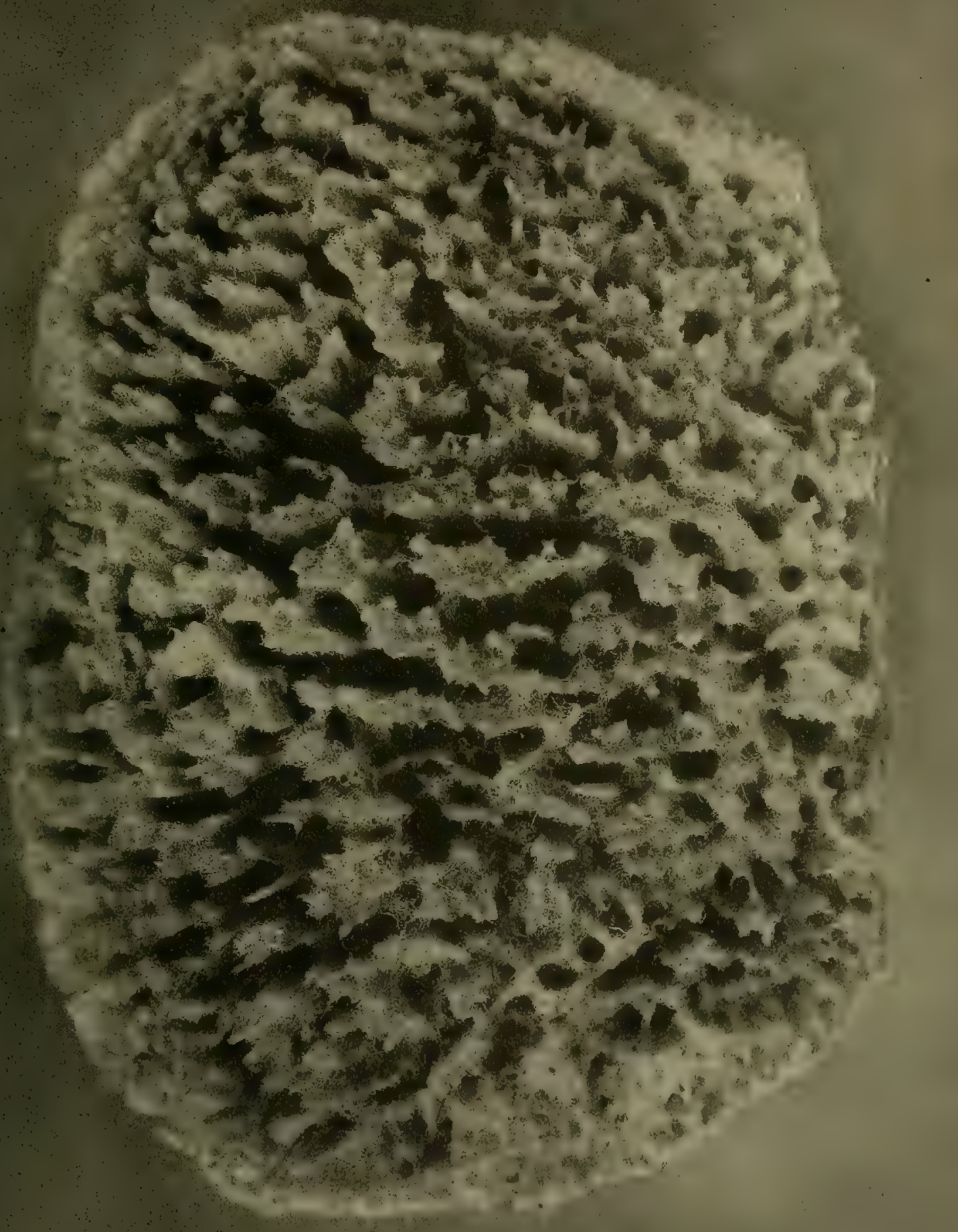





\section{Plate XLVIII}

Anclote grass sponge. Natural size. 


\section{IIIV.IX 91619}

. sria Lsтujsil .9gnoqa rasig gtolonA 


$$
\text { sinnohs }
$$

$2040,5 \times 1 \times 6$

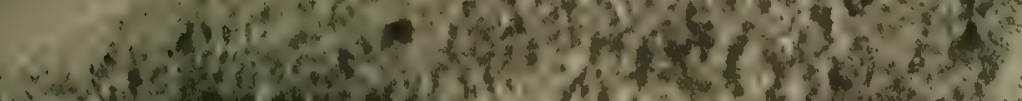

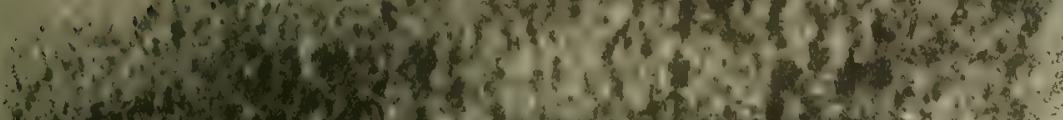

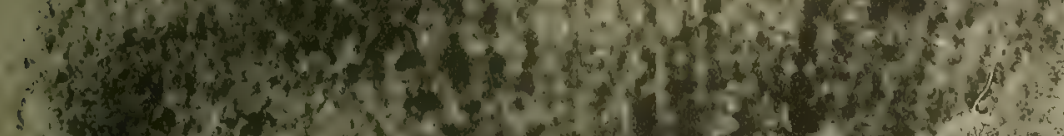

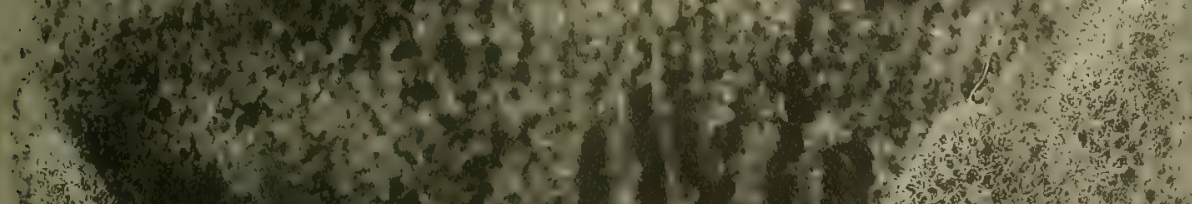
(n) (n) the

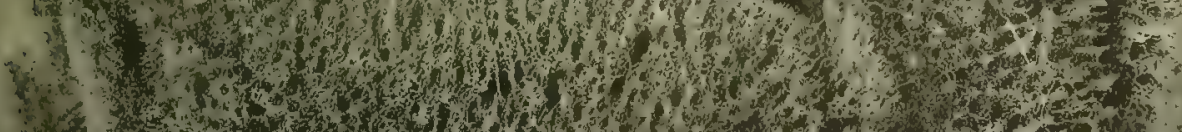
(n)

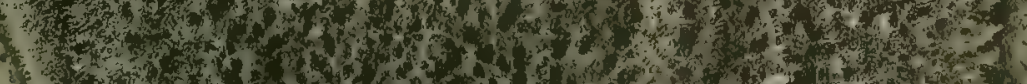

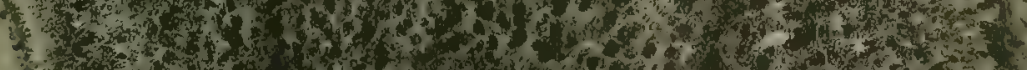
(n)

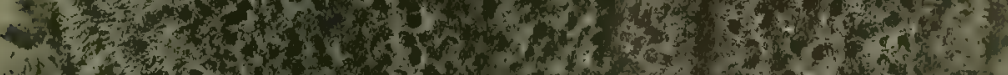
(1)

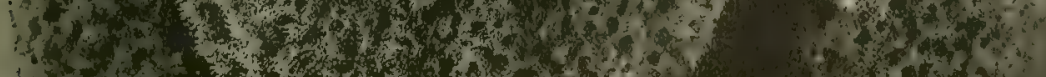
3.7n

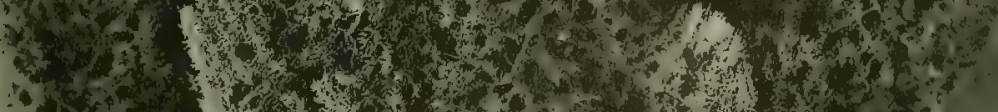

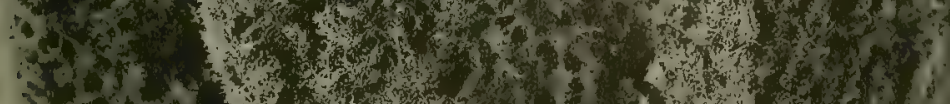

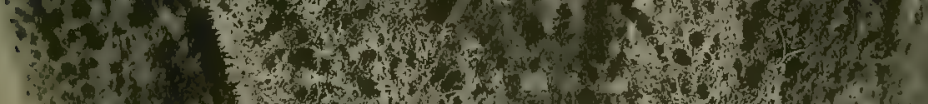

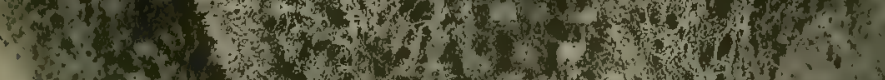

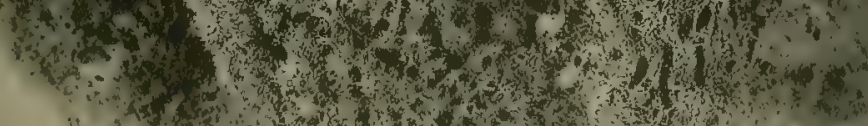

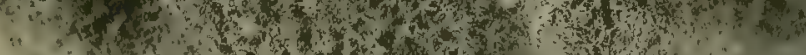

$$
x^{2}+x^{2}
$$



Plate XLIX

Florida Key grass sponge. Natural size. 
m 1.

$\therefore \quad \therefore \quad \cdots+\cdots$ 


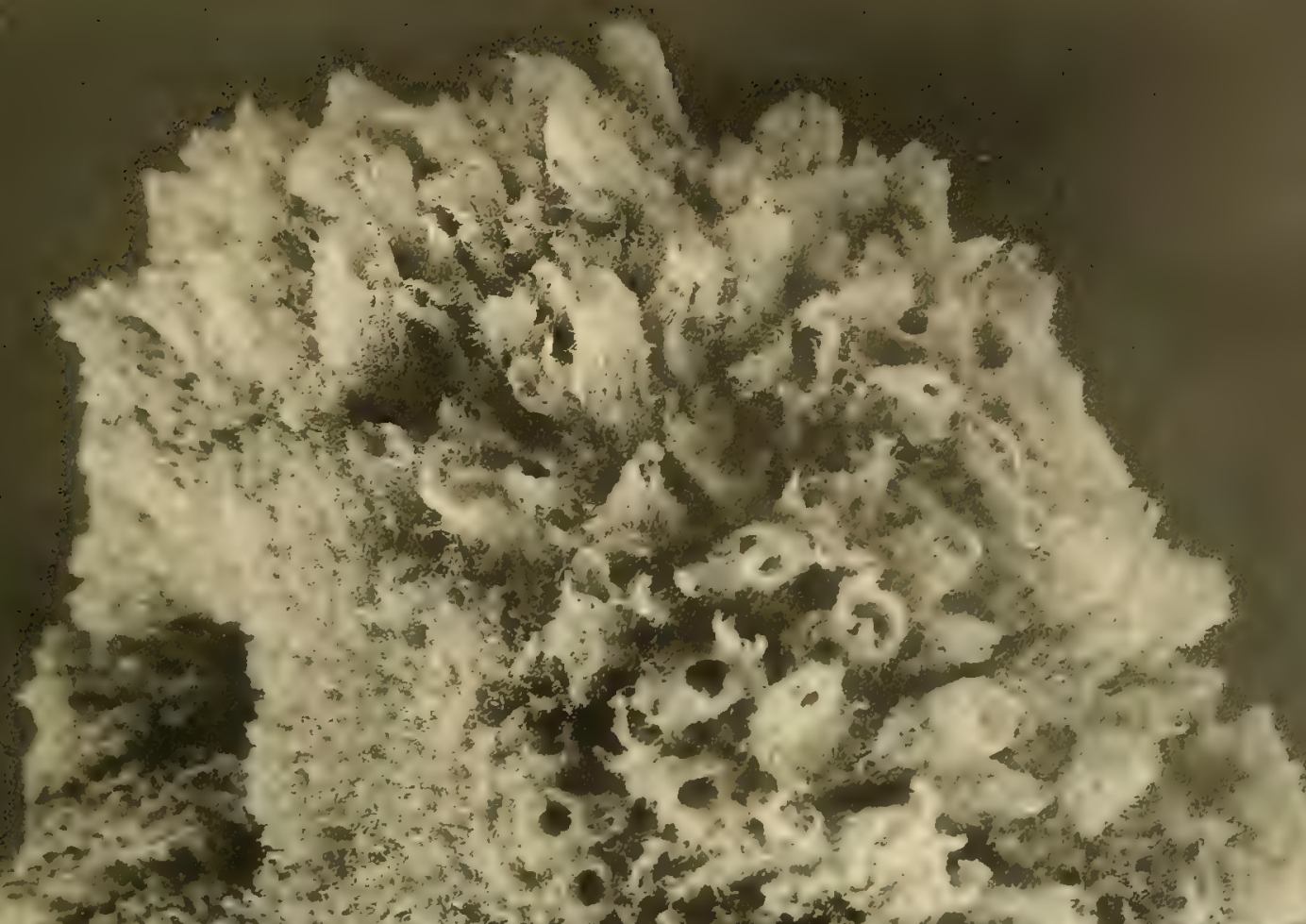

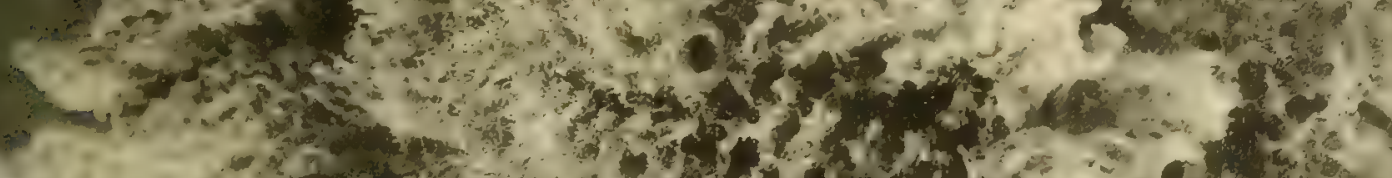

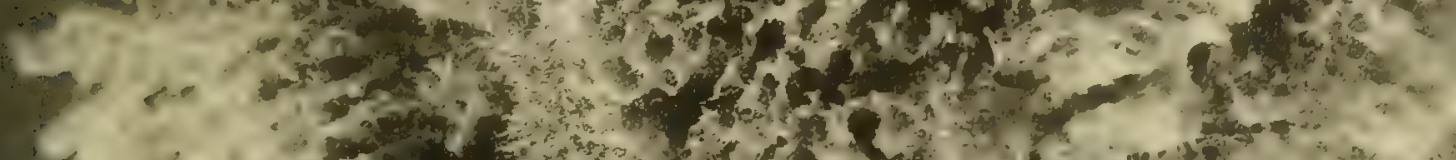

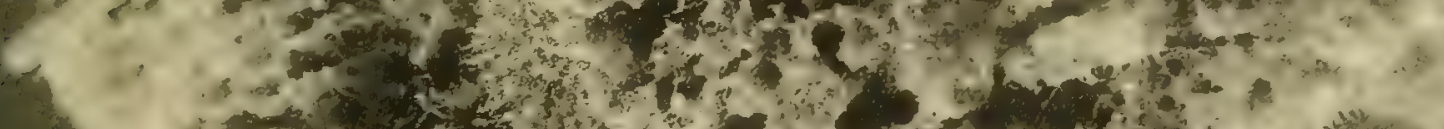

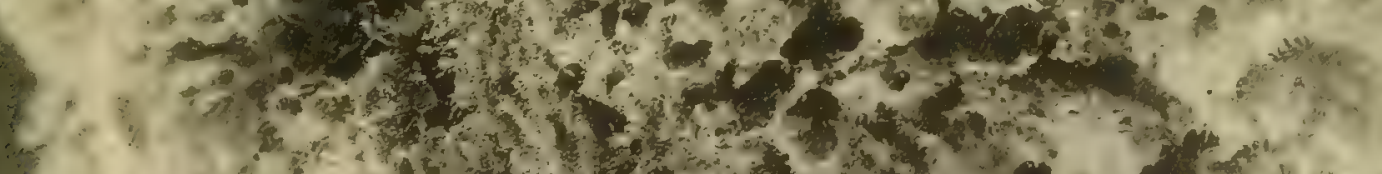

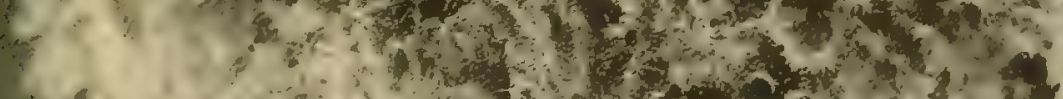

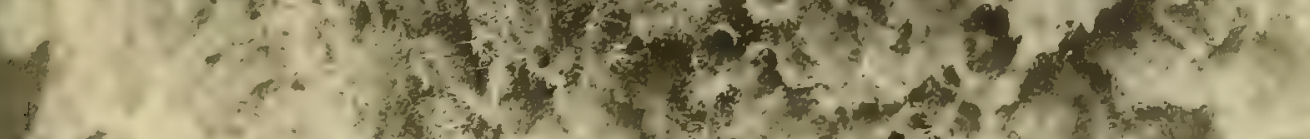
40 (1.

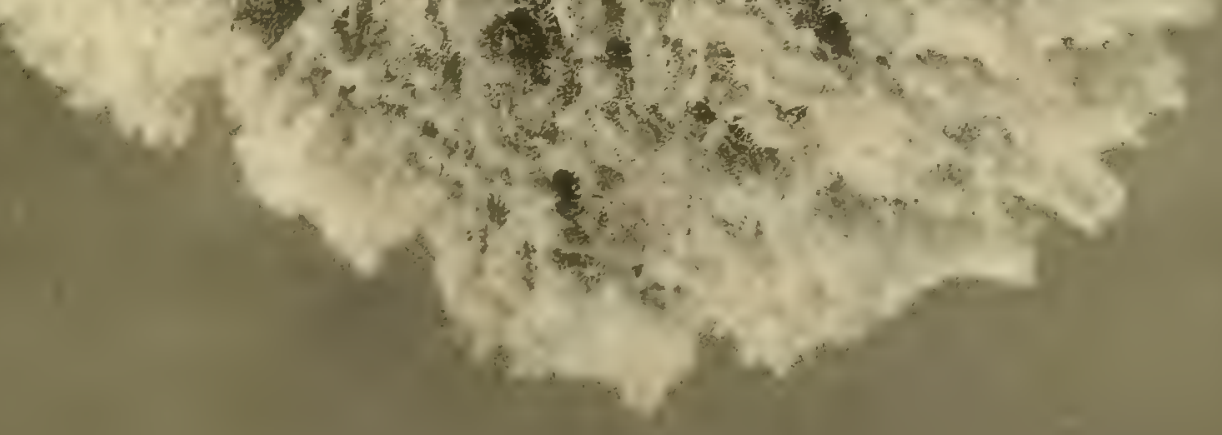





\section{Plate LI}

Florida Key grass sponge, top view. Natural size. 
IJ भ.

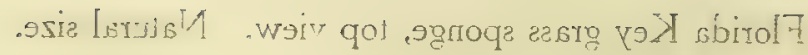


(n)

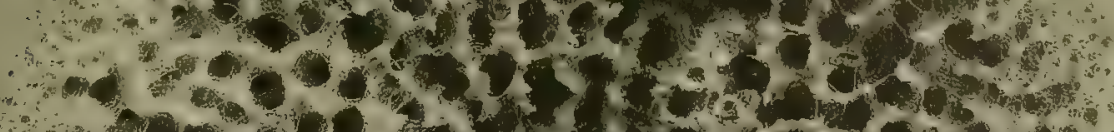

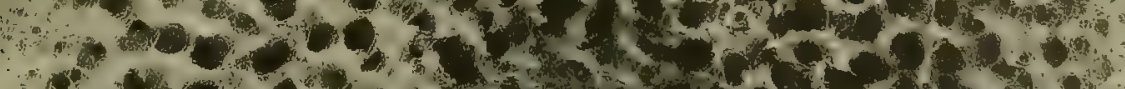

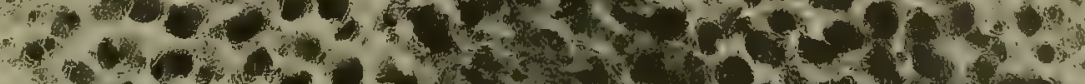

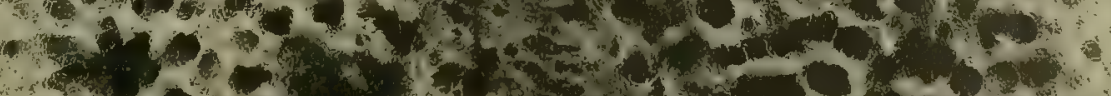

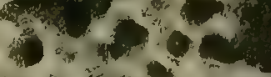

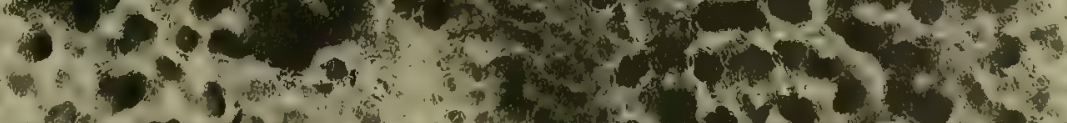

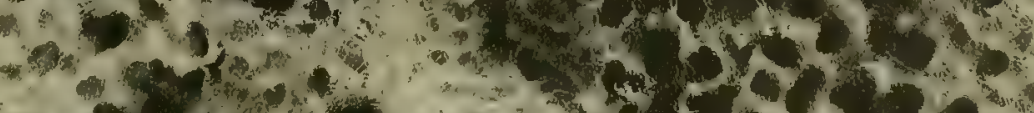

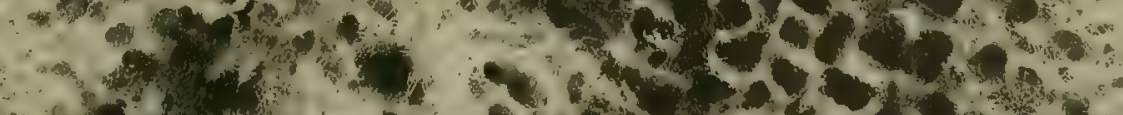

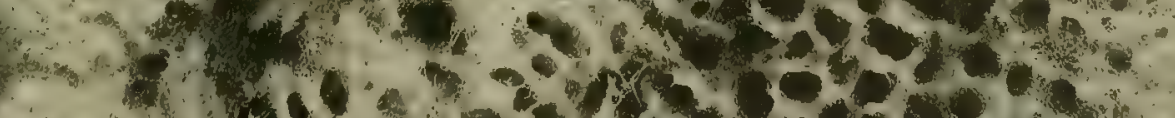

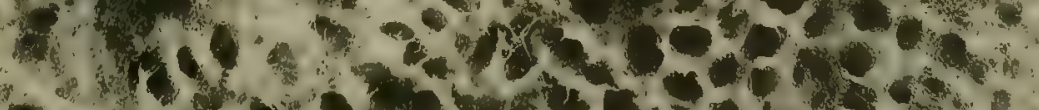

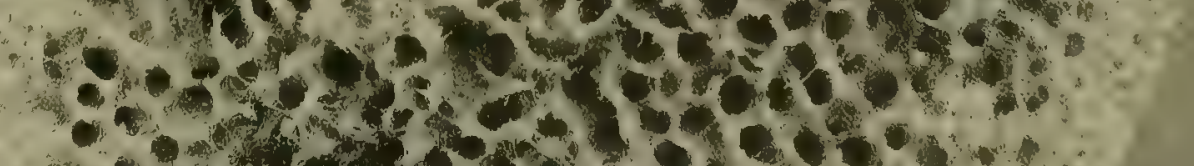

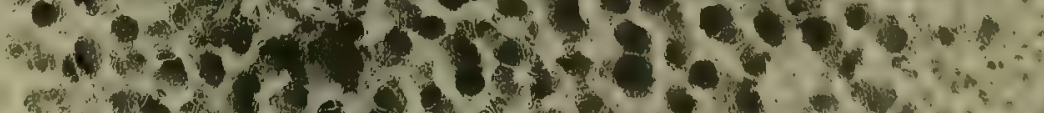
a)

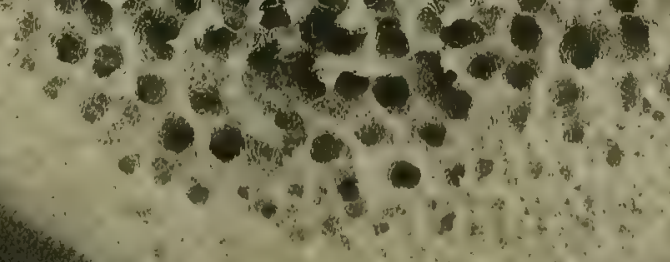





\section{Plate LII}

\section{Bahama grass sponges. Natural size.}


II. 91.19

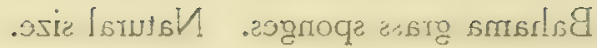




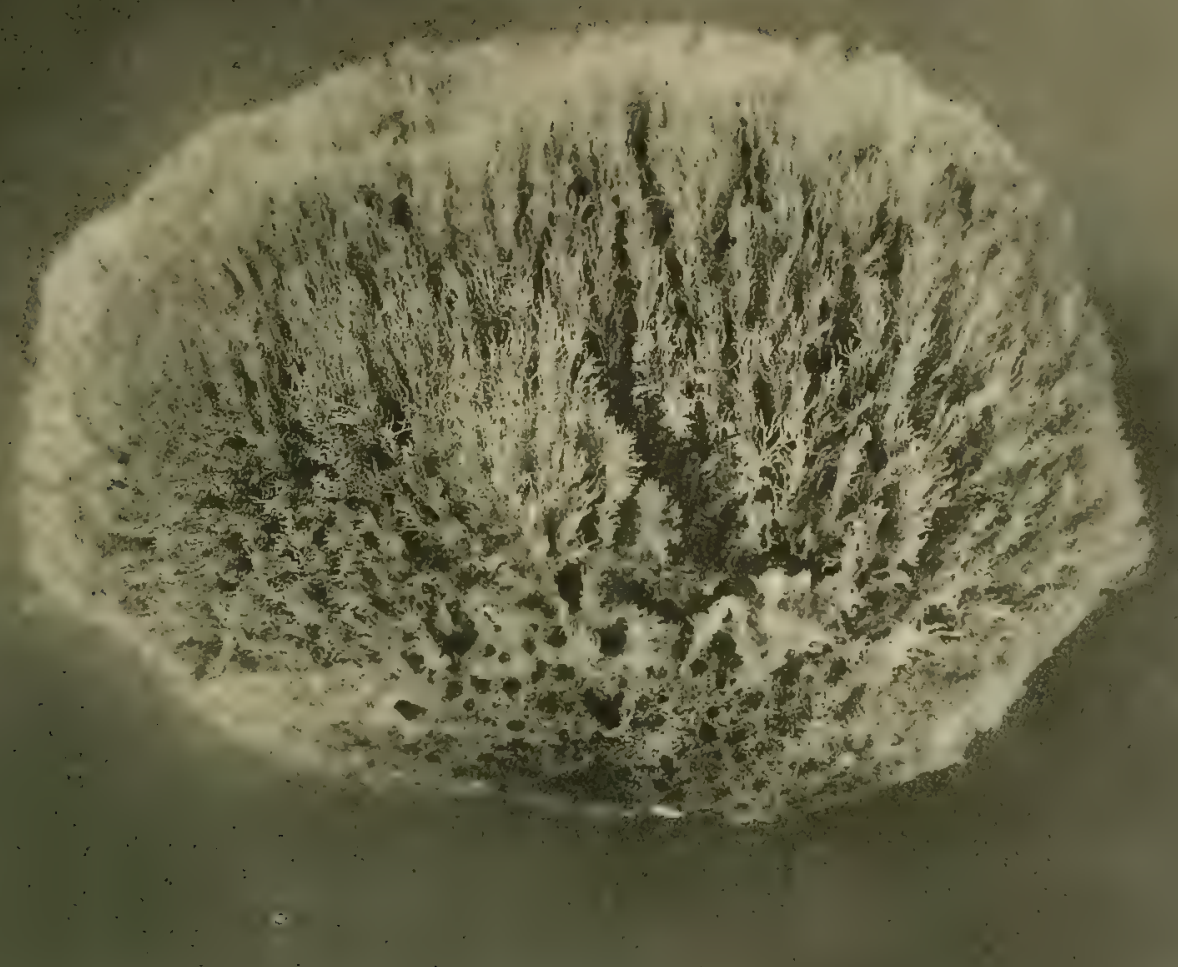

(4)

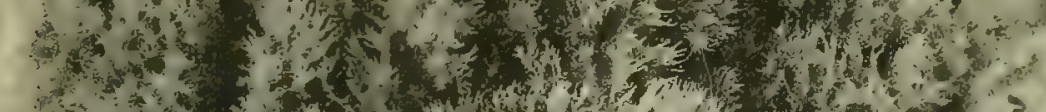

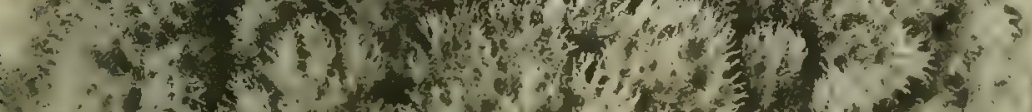

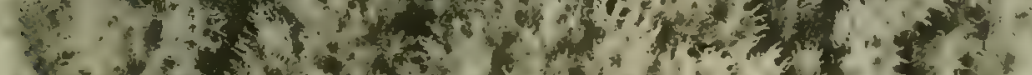

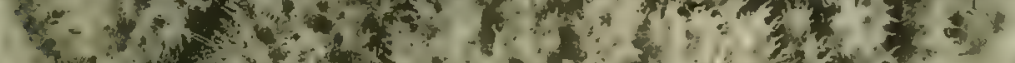

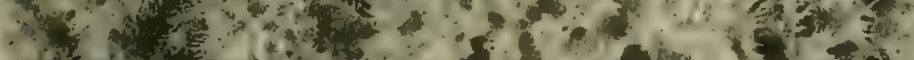
Tor

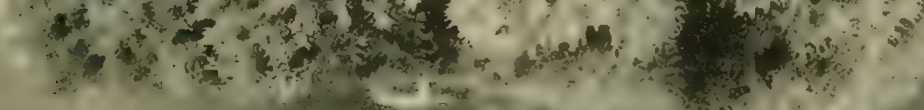



Plate LIII

Cuba grass sponges. Natural size. 
III] $=1619$

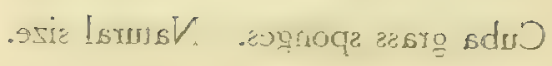



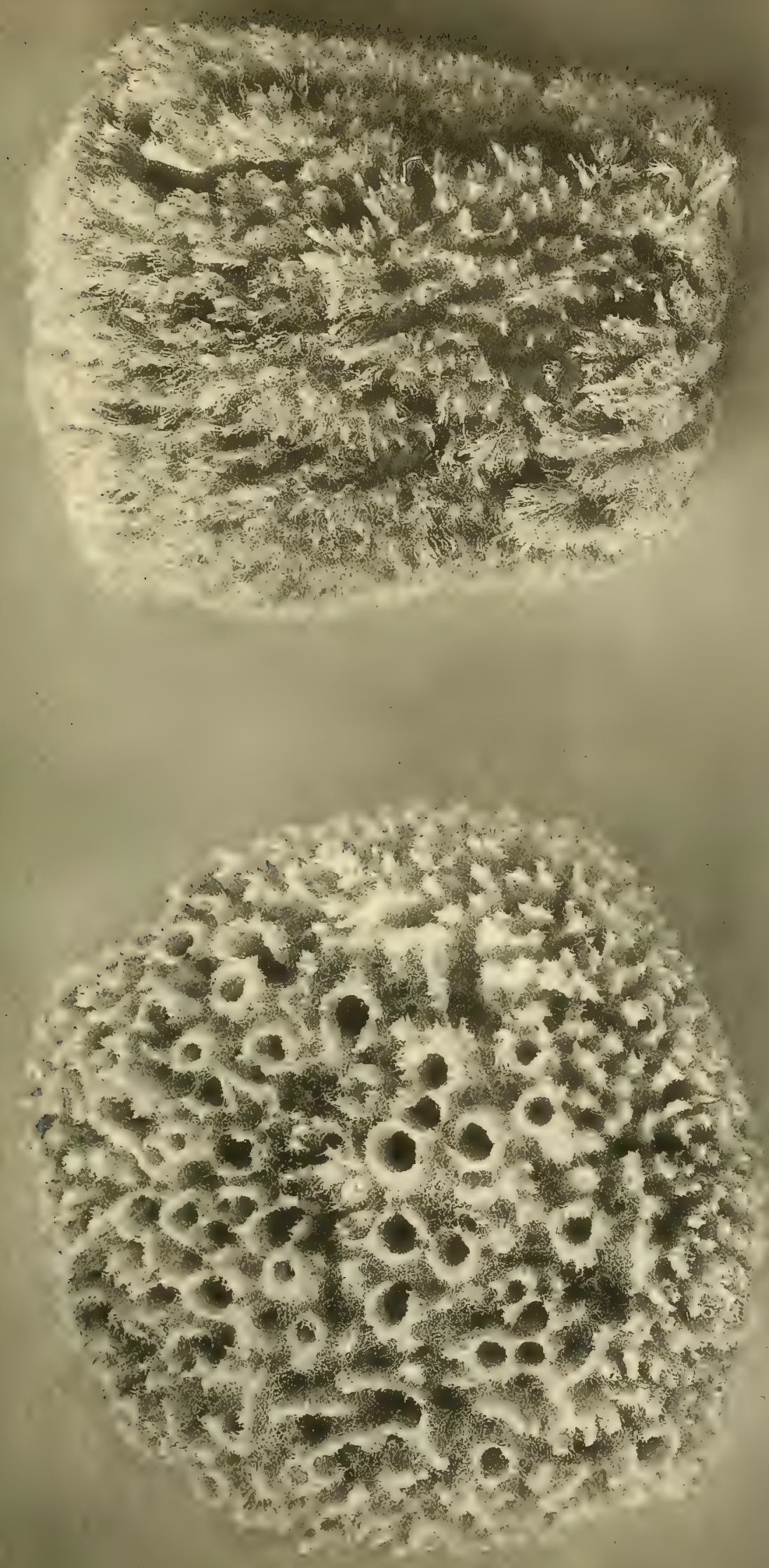

Plate LIV

Florida glove sponge. Natural size. 
VIJ ग619

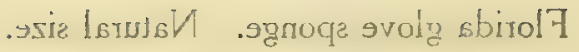




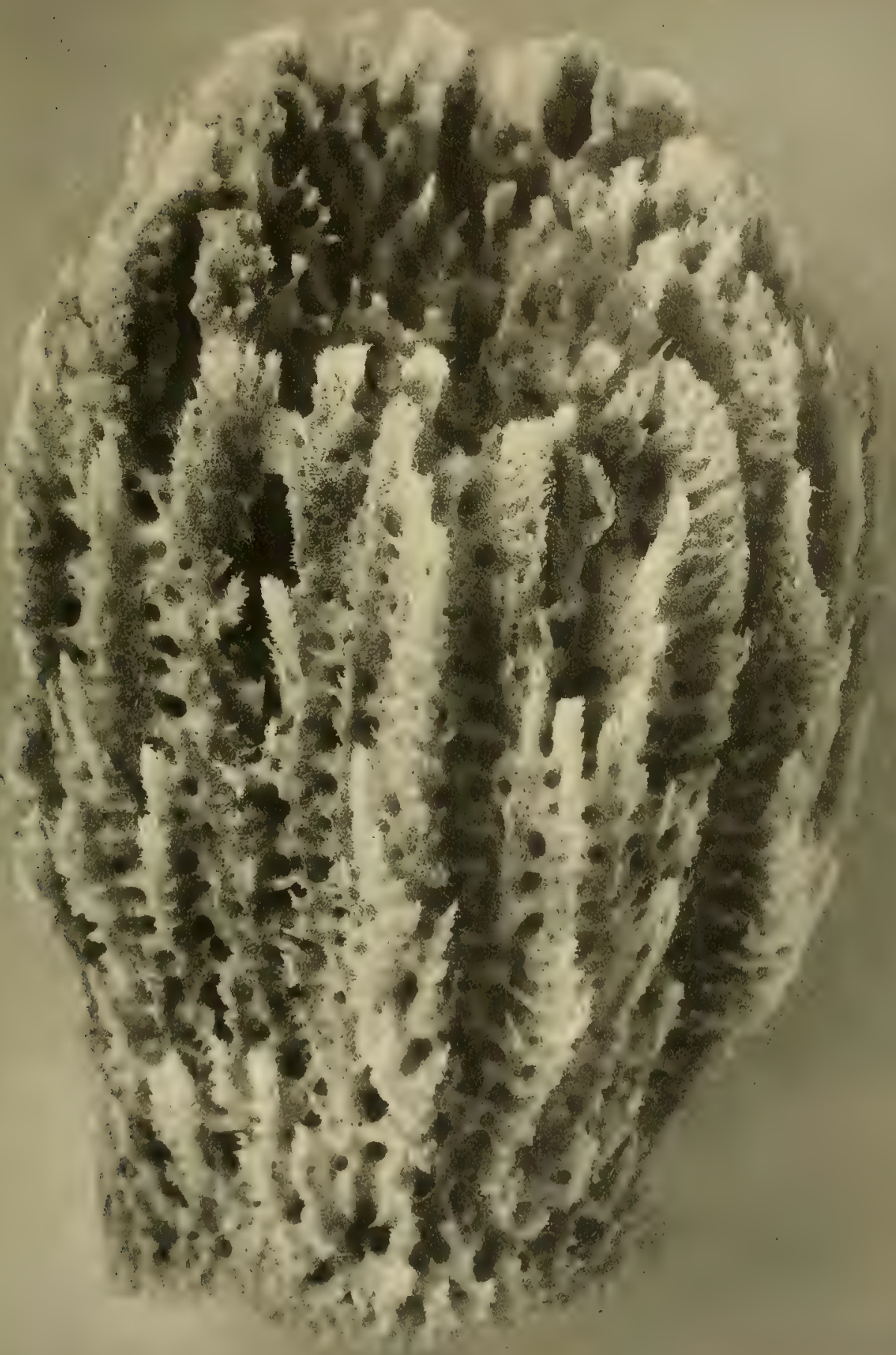





\section{Plate LV}

Cuba reef sponge. Natural size. 


$$
\text { VI } \cdots 1519
$$

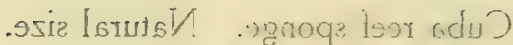




Plate LVI

Fig. 1.-Bahama reef sponge, side view. Natural size.

Fig. 2.-Bahama reef sponge, top view. Natural size. 


\section{IV] 9t 6 [9}

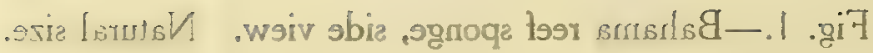

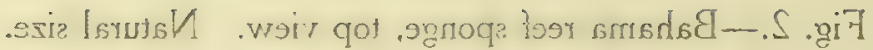




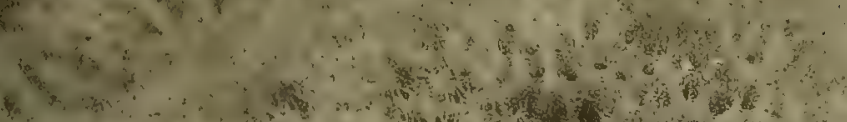

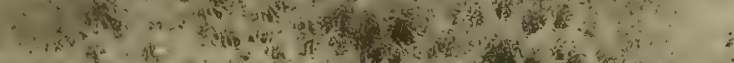

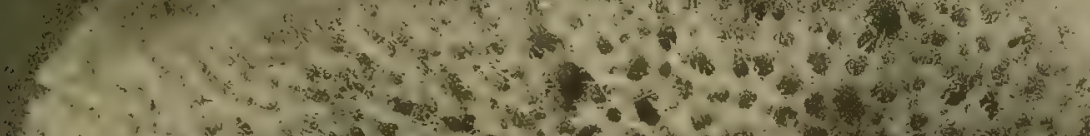

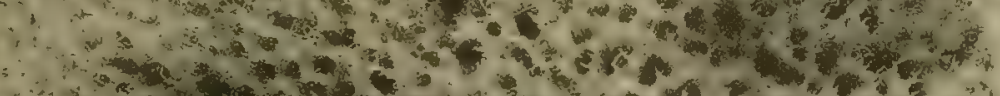

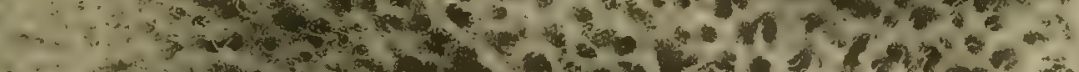

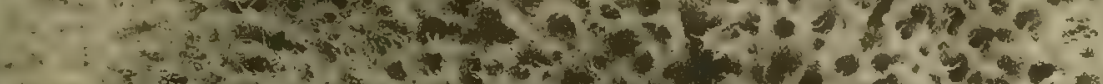

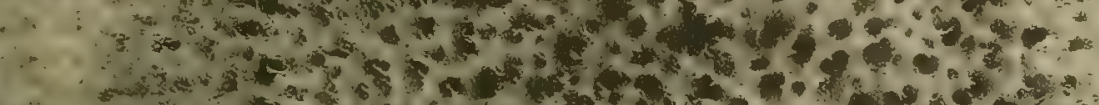
2. $\therefore \quad$ a

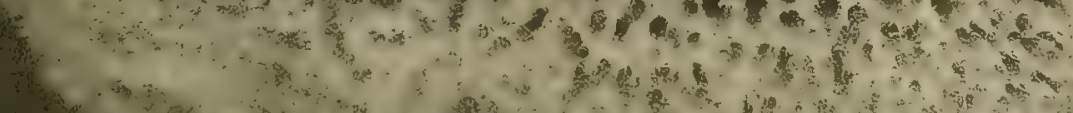

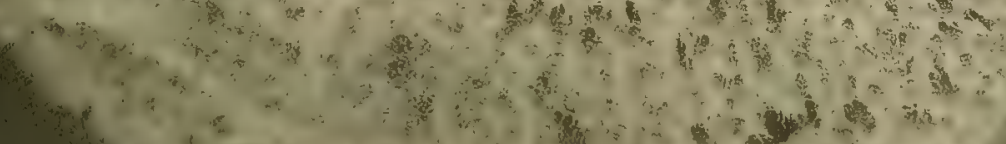

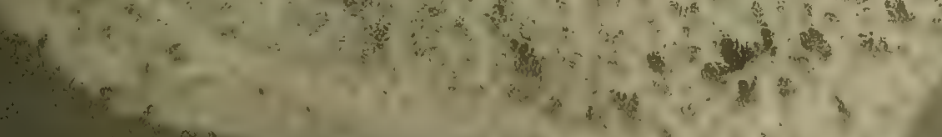
. a. $-6,0$

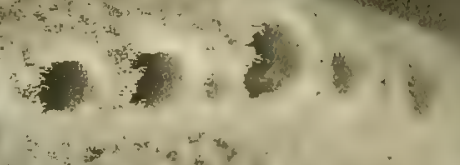



Plate LVII

Cuba hardhead sponges. Natural size. 


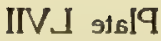

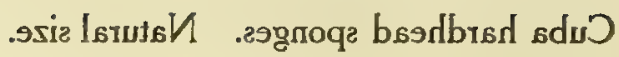




\section{and}

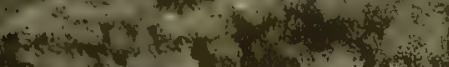

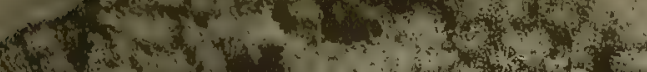

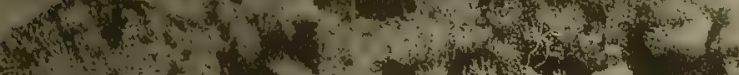

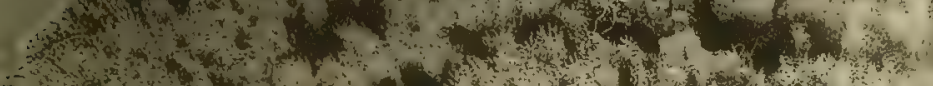

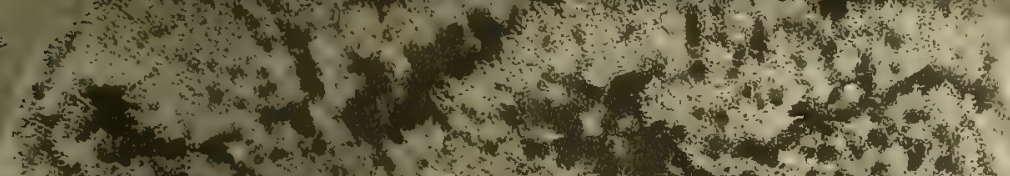

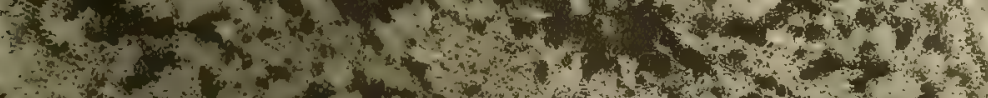

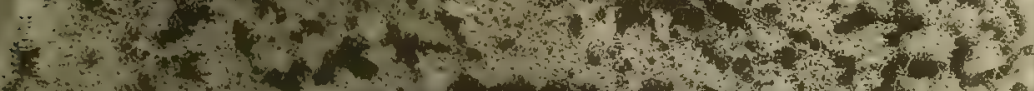
(3)

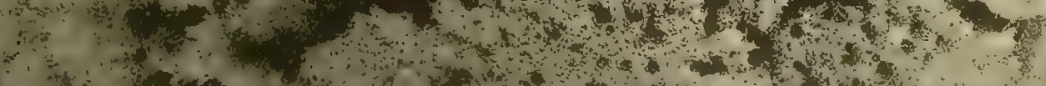

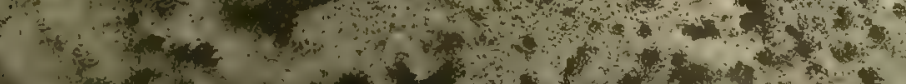

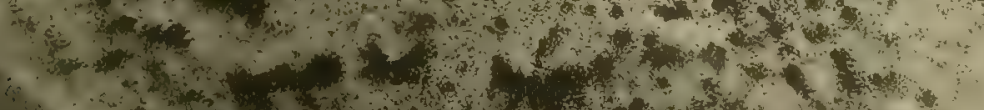

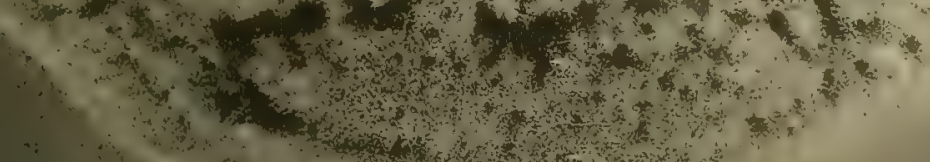

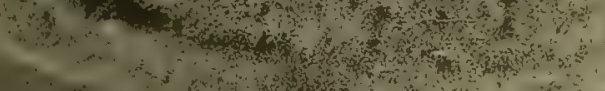

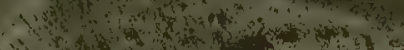

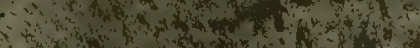

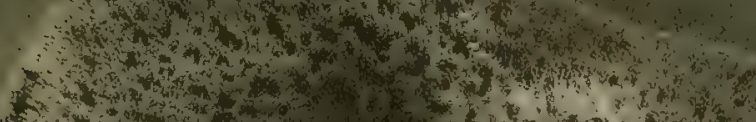

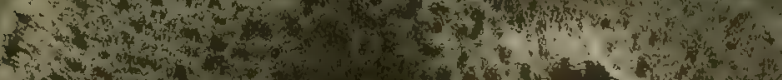

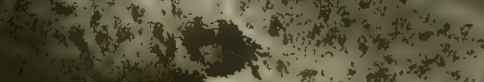

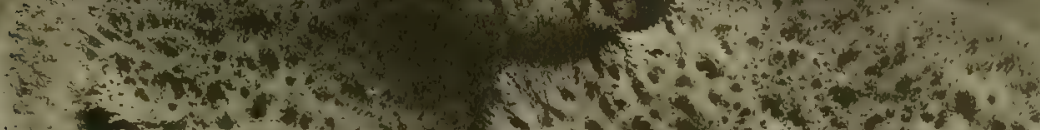

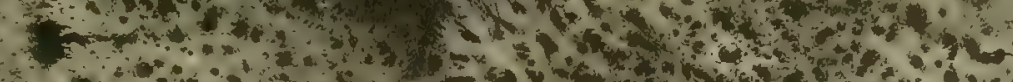

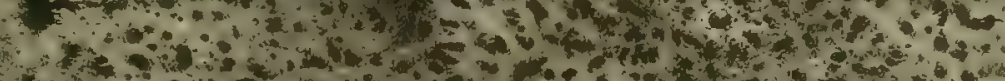

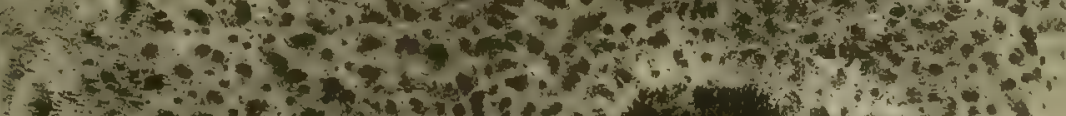

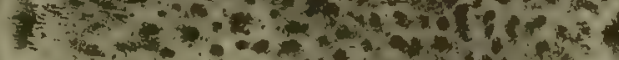

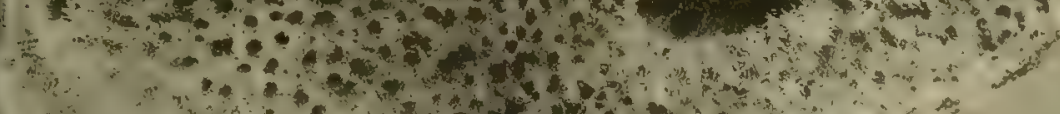

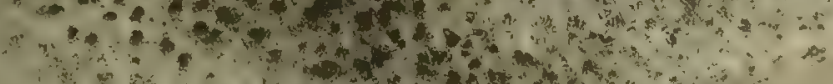

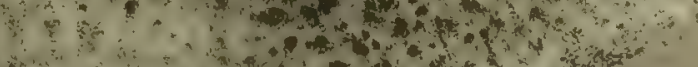

a 



\section{Plate LVIII}

Florida wire sponge. Natural size. 
IIIV! 915 IT

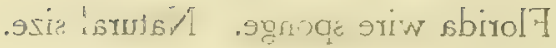




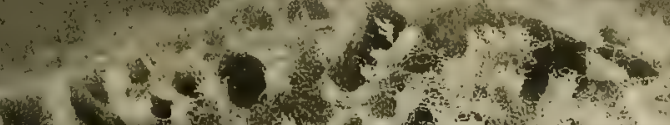

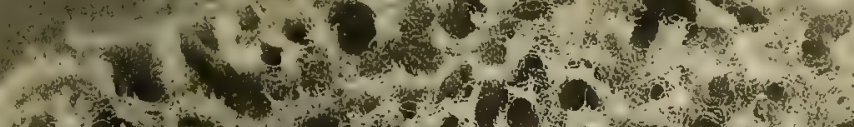

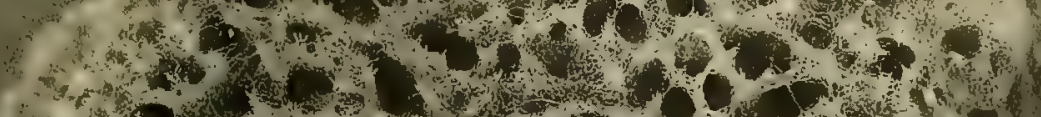

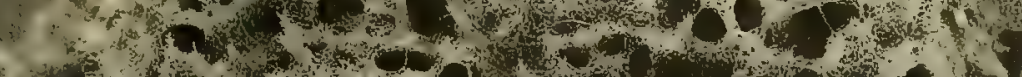

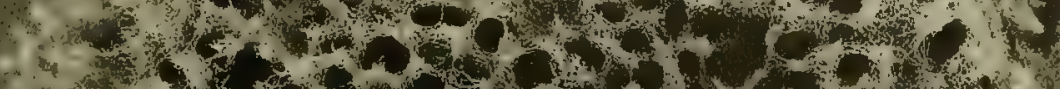

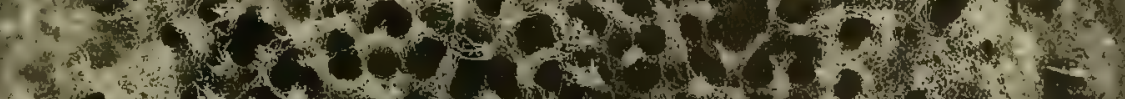

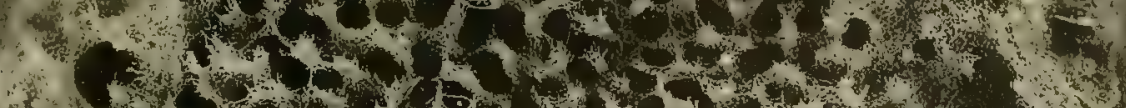

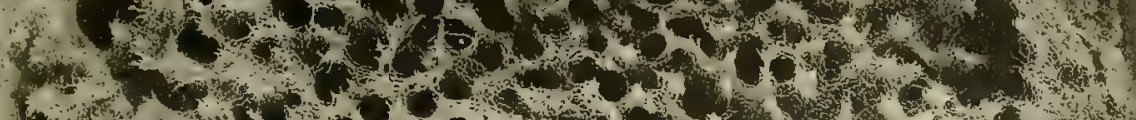
(4)

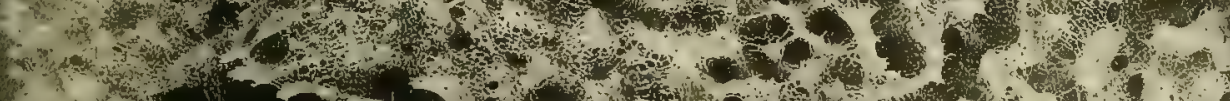

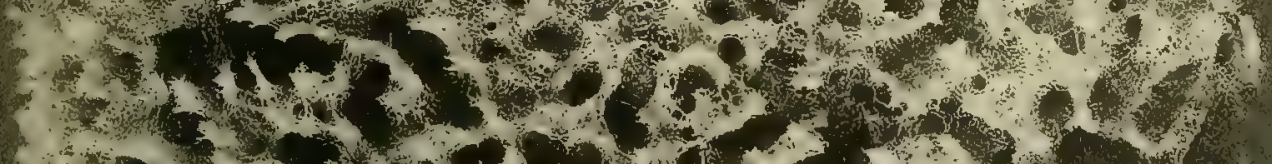

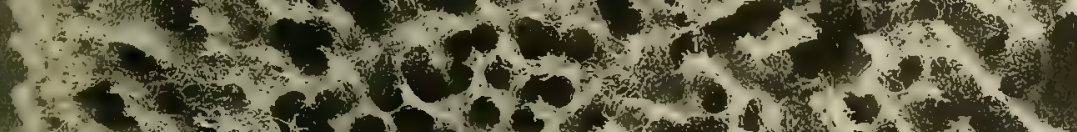

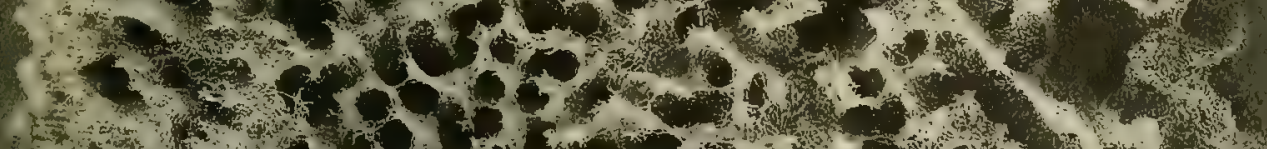

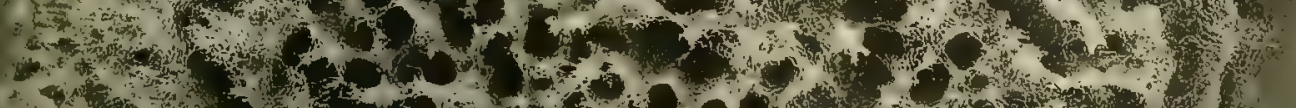

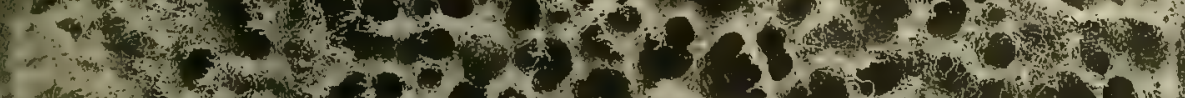

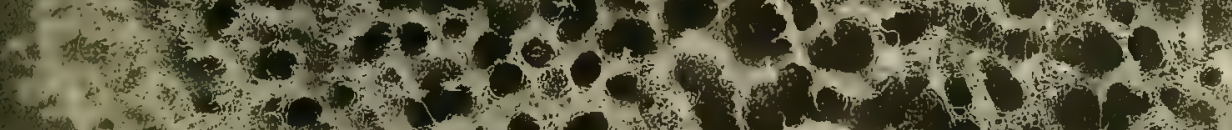

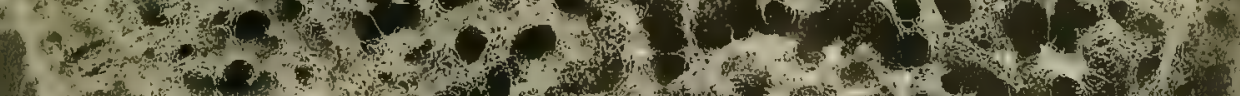

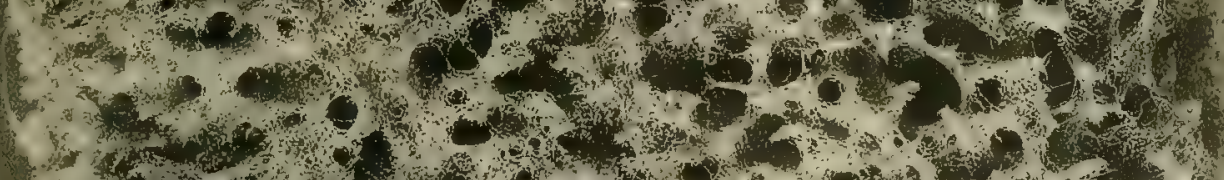

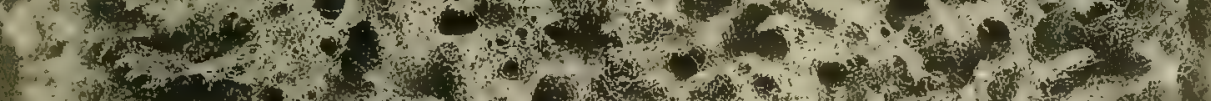

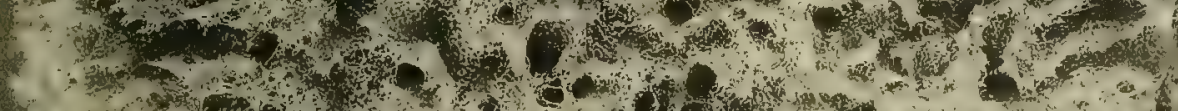

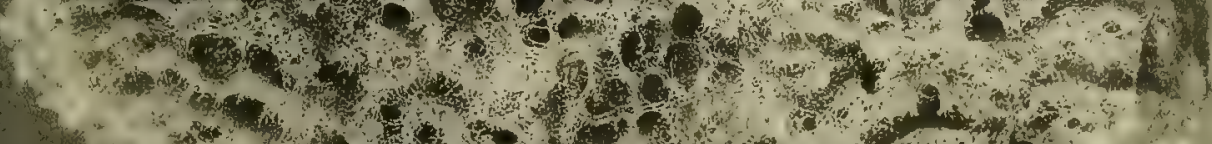

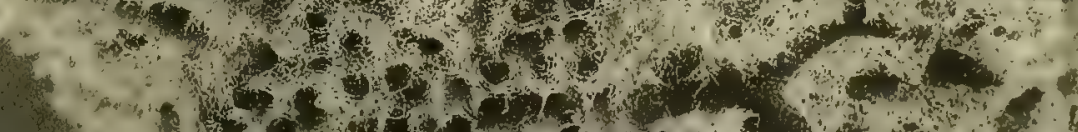

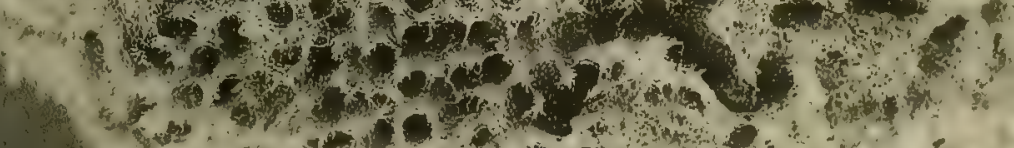

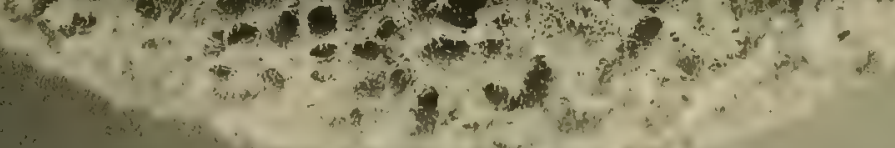



Plate LIX

Florida wire sponge, top view. Natural size. 
XI. I 95

.9rie 1 


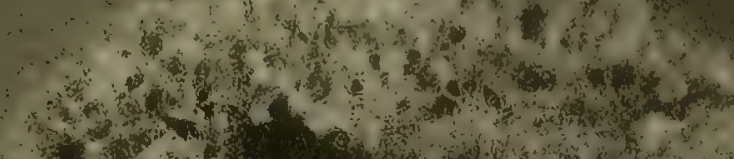

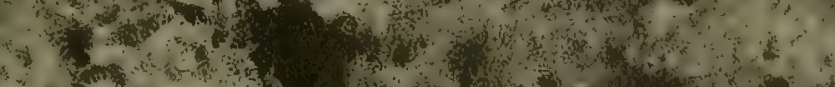

(n)

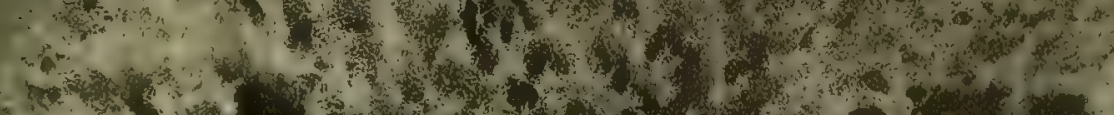

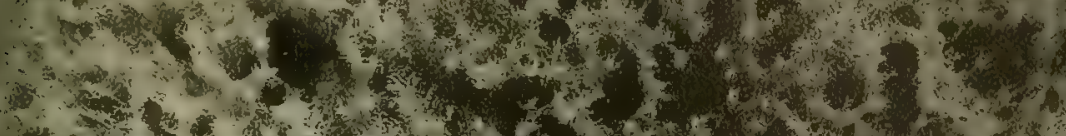

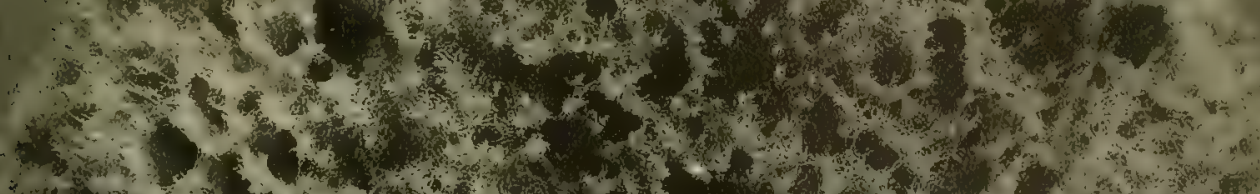

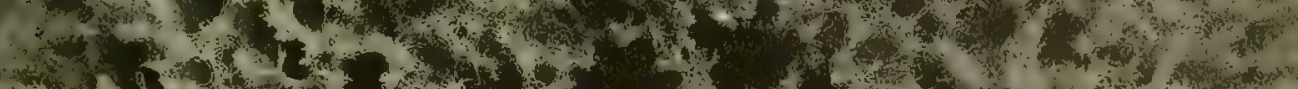

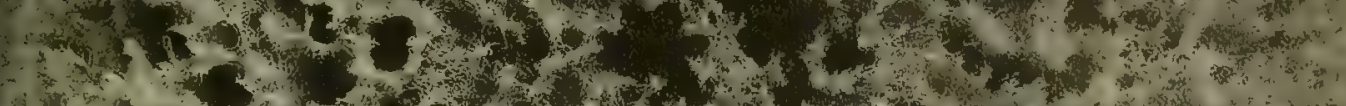

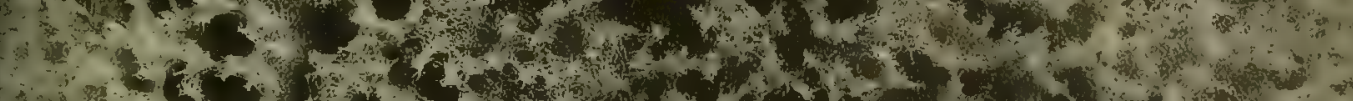

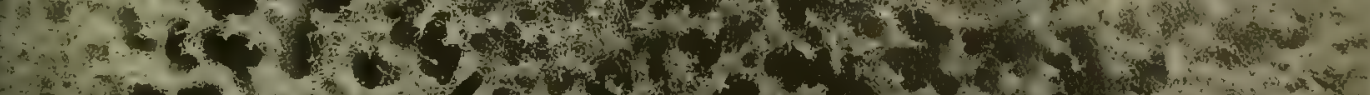

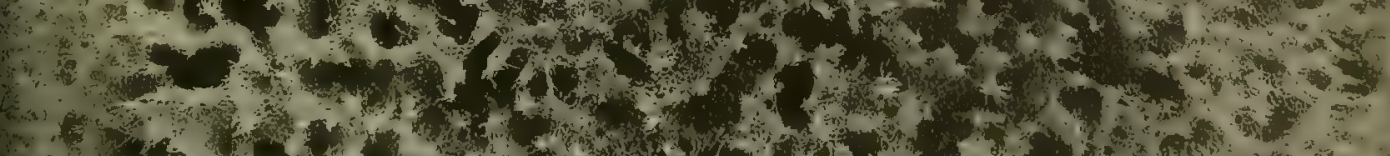

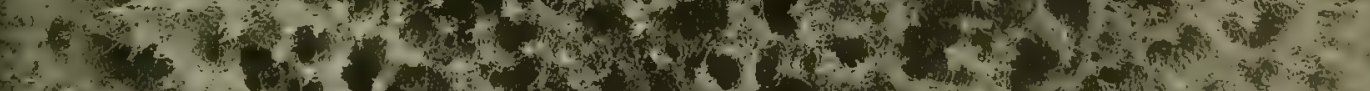
20

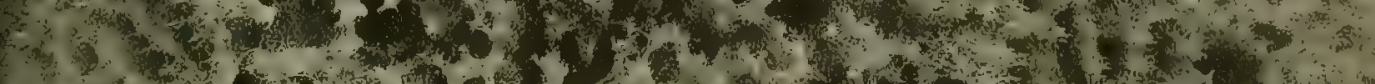

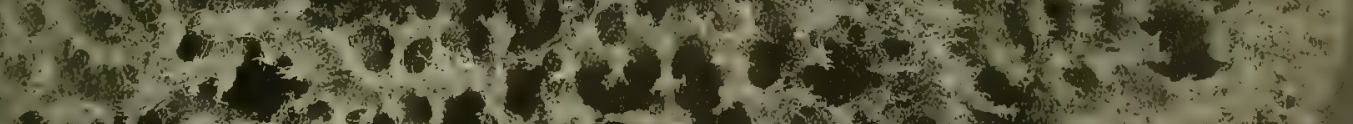

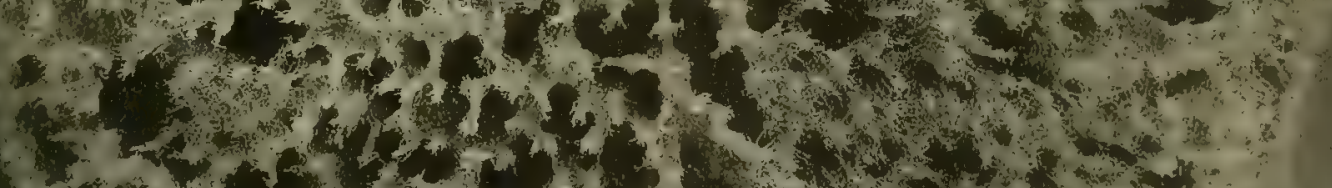

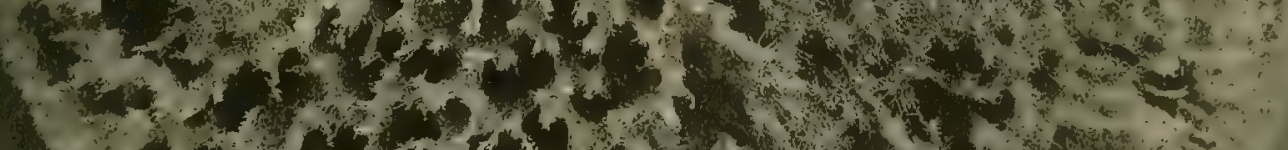

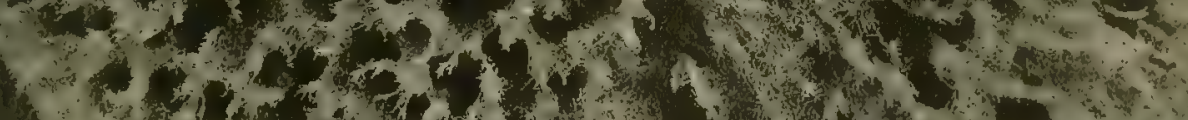

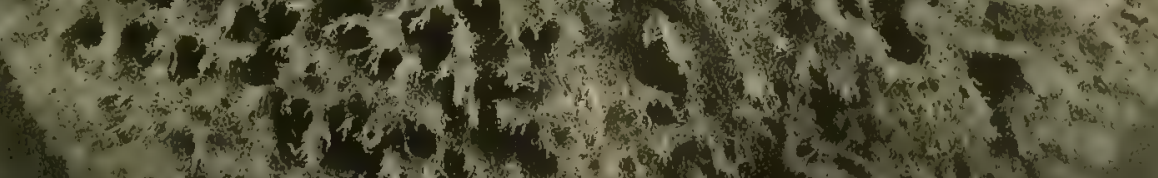

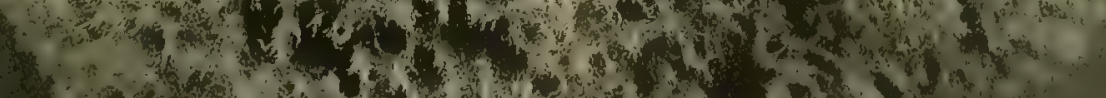

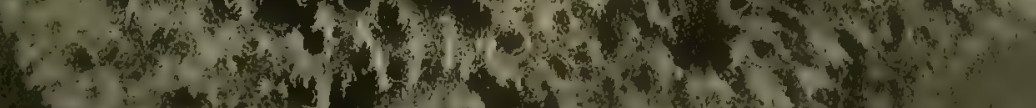

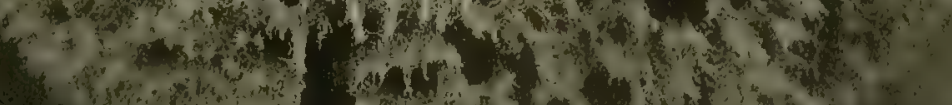

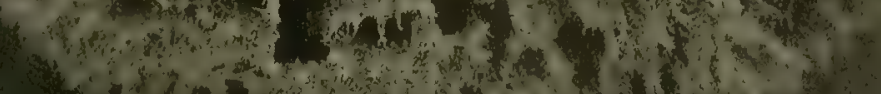

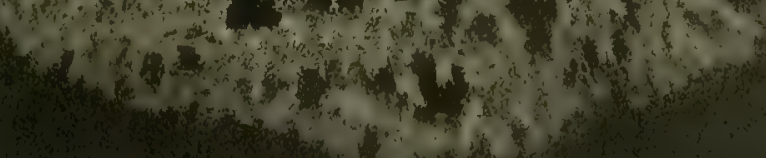



Plate LX

Turkey cup sponges, Mediterranean Sea. Natural size. 
$X_{\text {II }}$ 9ा 19

. șia Ísuis . . 

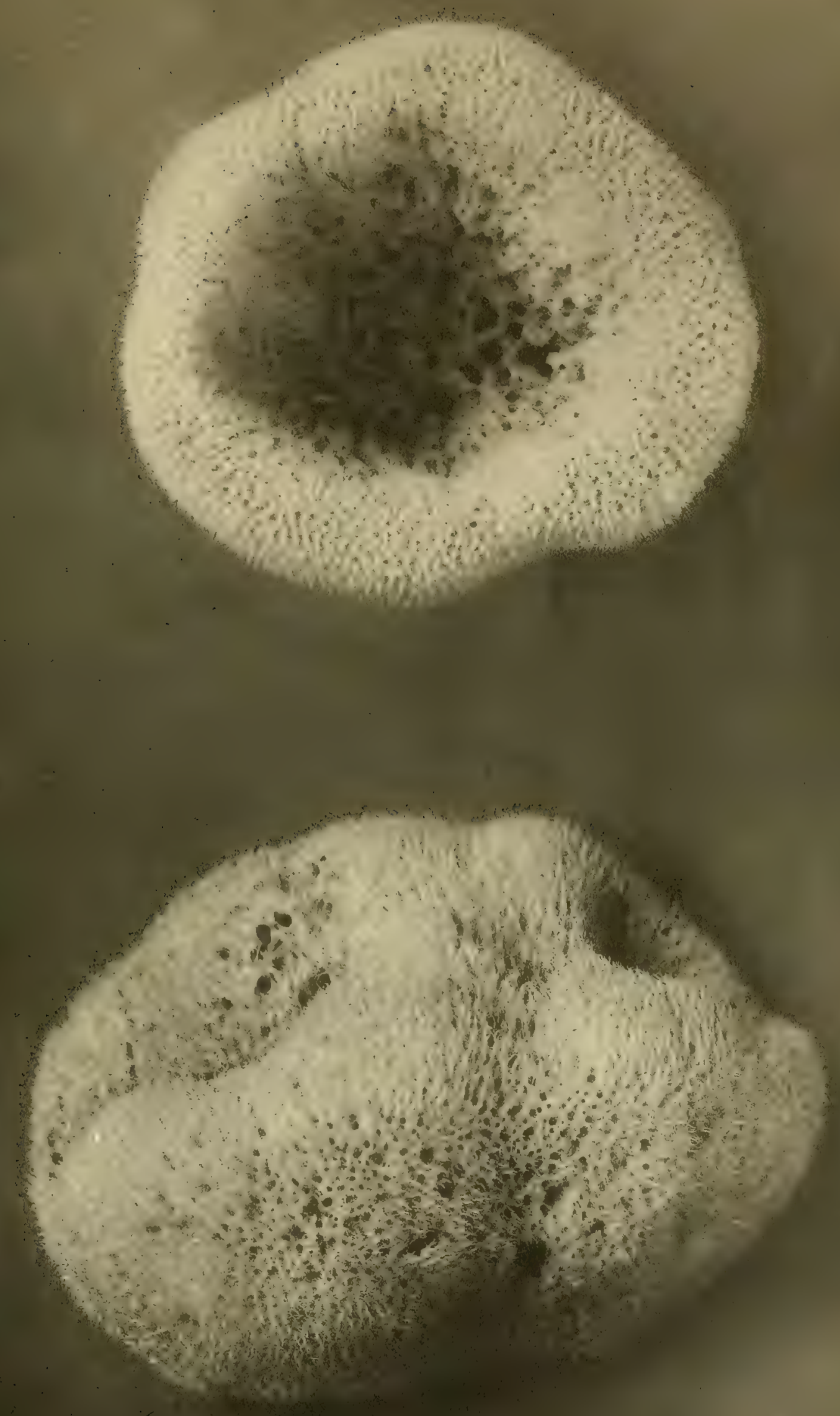



\section{Plate LXI}

Fig. I.-Turkey solid sponge, Mediterranean Sea. Natural size.

Fig. 2.-Toilet sponge, Mediterranean Sea. Natural size. 


\section{IX] sto 19}

.95iz I

sxí Isтuts . . 


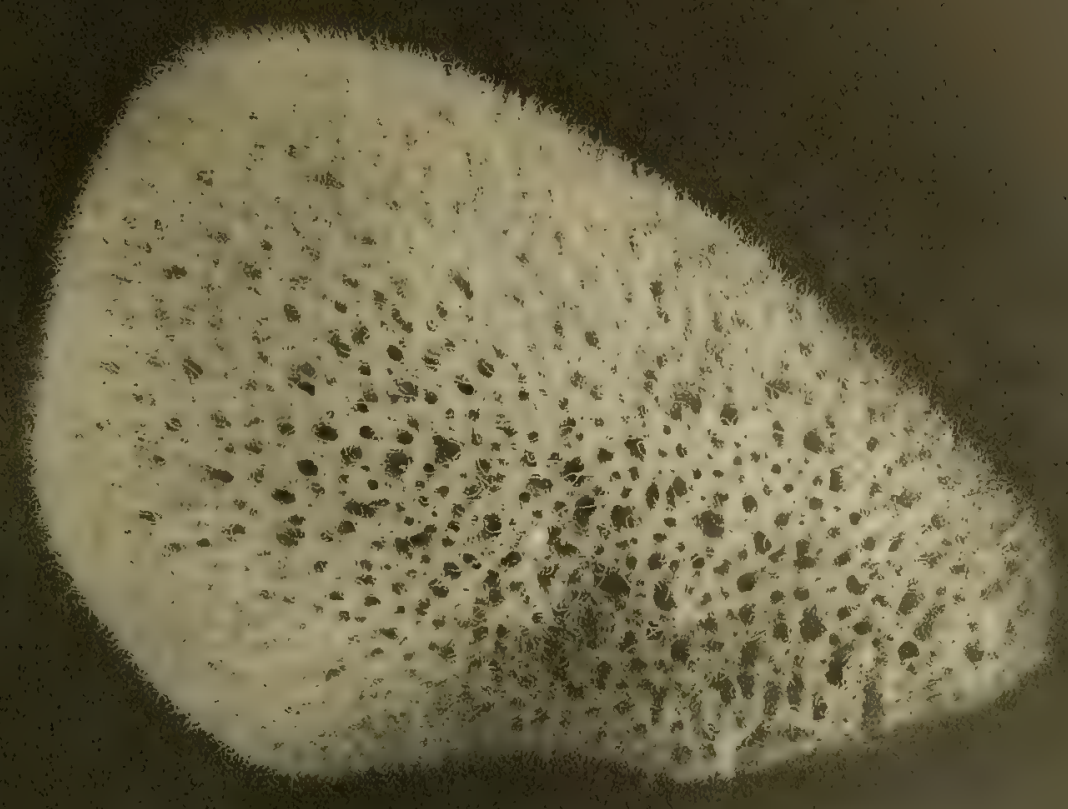



Plate LXII

Toilet sponge, Mediterranean Sea. Natural size. 


\section{IIXJ 91619}

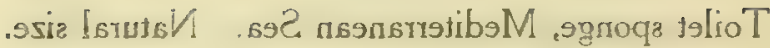




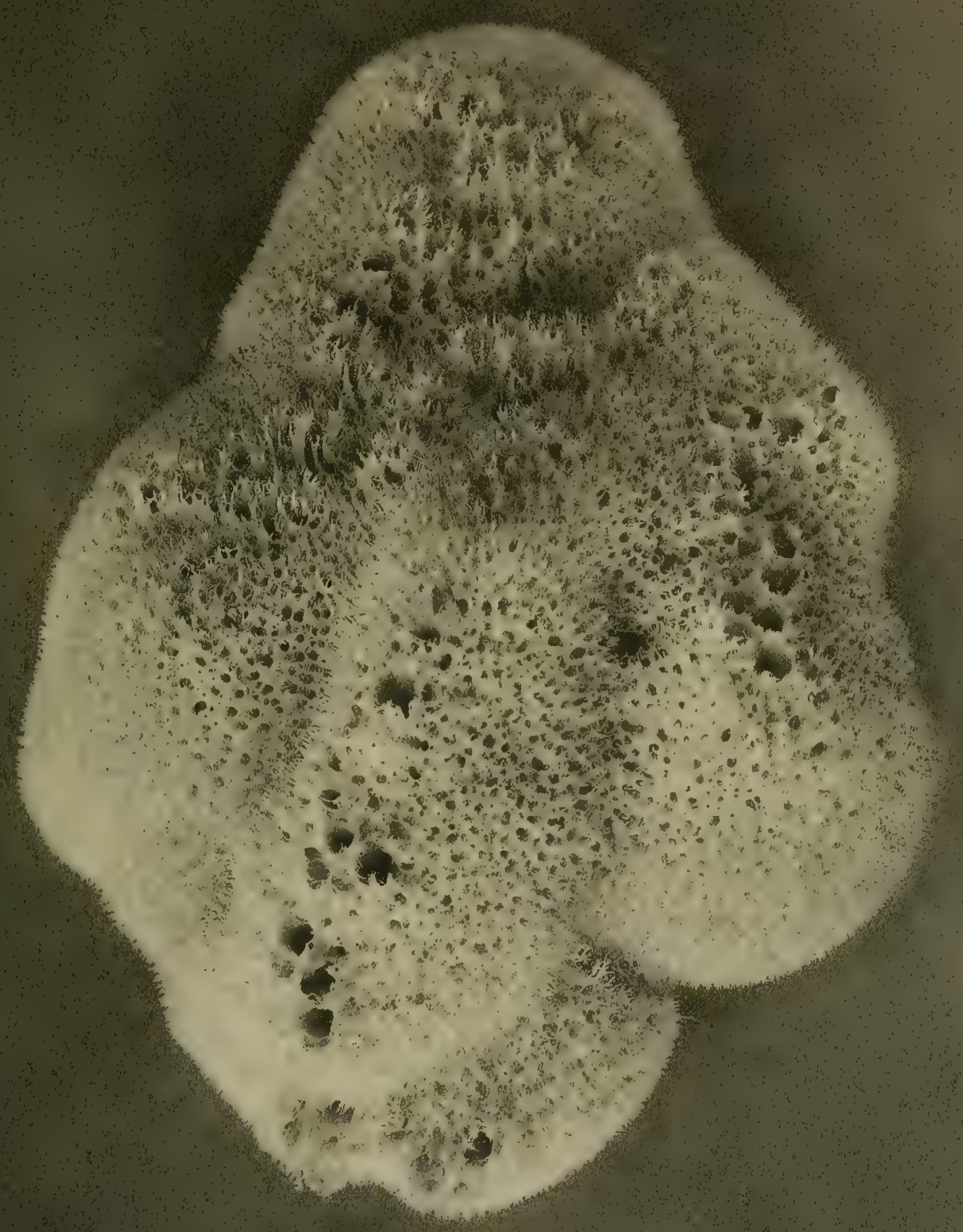



Plate LXIII

Fig. 1.-Philippine toilet sponge, Sitanki, P. I. Side view, natural size.

Fig. 2.-Philippine toilet sponge, Sitanki, P. I. Top view, natural size. 


\section{IUX.I 9.619}

I . 9 sie

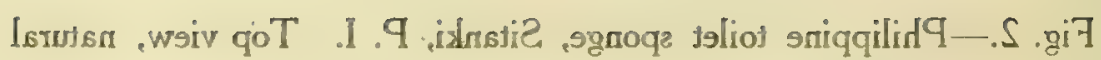
.9 siz 


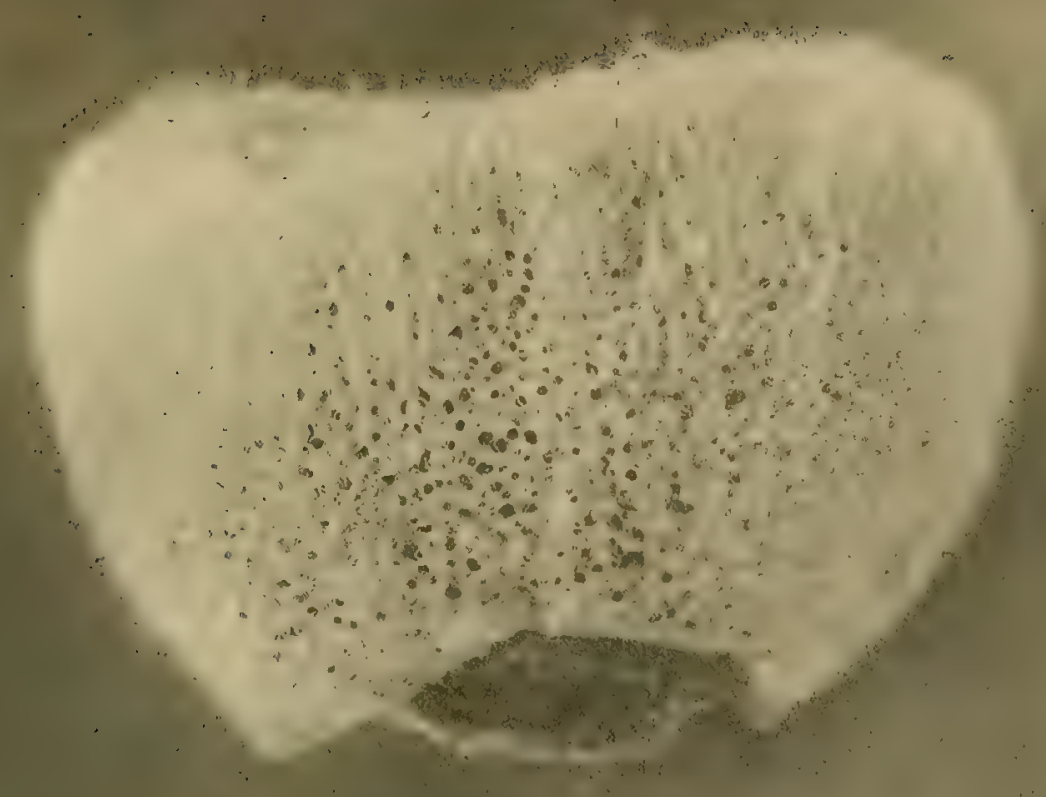

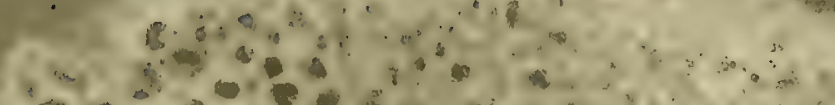

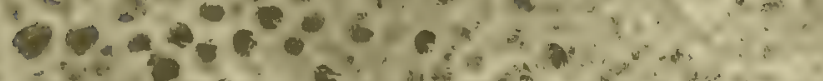
$4 e^{4}+0$

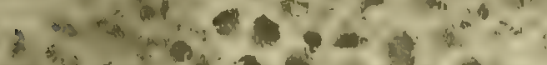

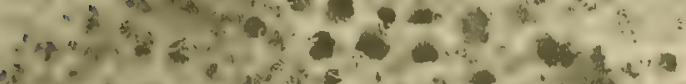
e. $=10$ a

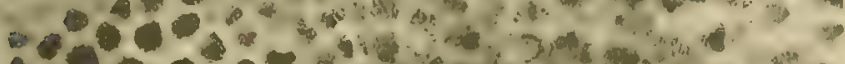

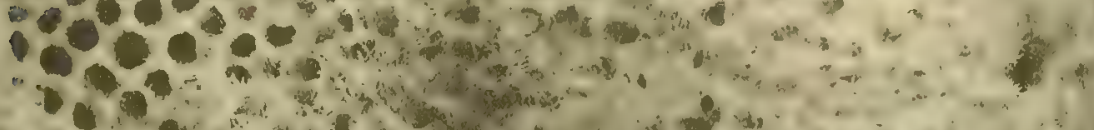

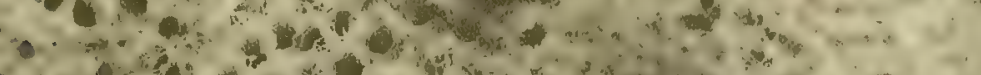

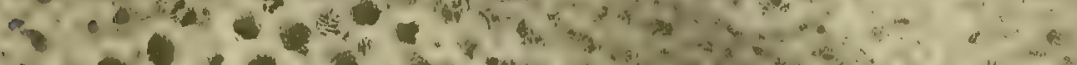

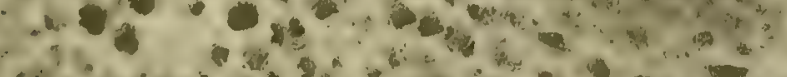

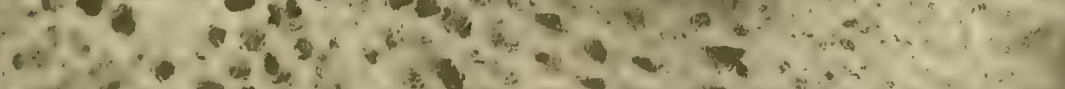

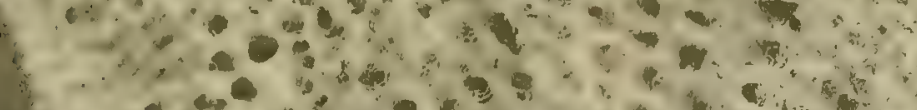

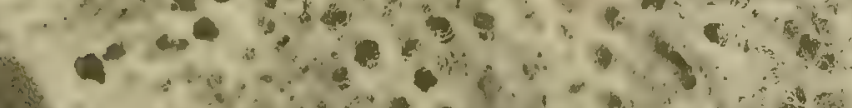

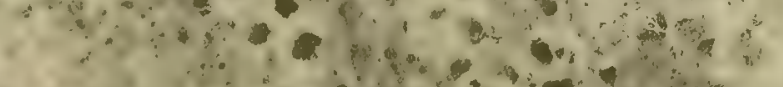
- os 



\section{Plate LXIV}

Fig. 1.-Zimocca sponge, Mediterranean Sea. Side view, natural size.

Fig. 2.-Zimocca sponge, Mediterranean Sea. Top view, natural size. 
VIX.I. Sis 19

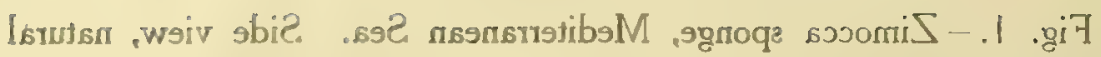
.9si2

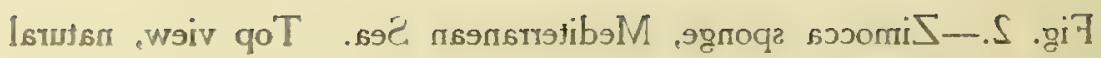
$.95 i 2$ 


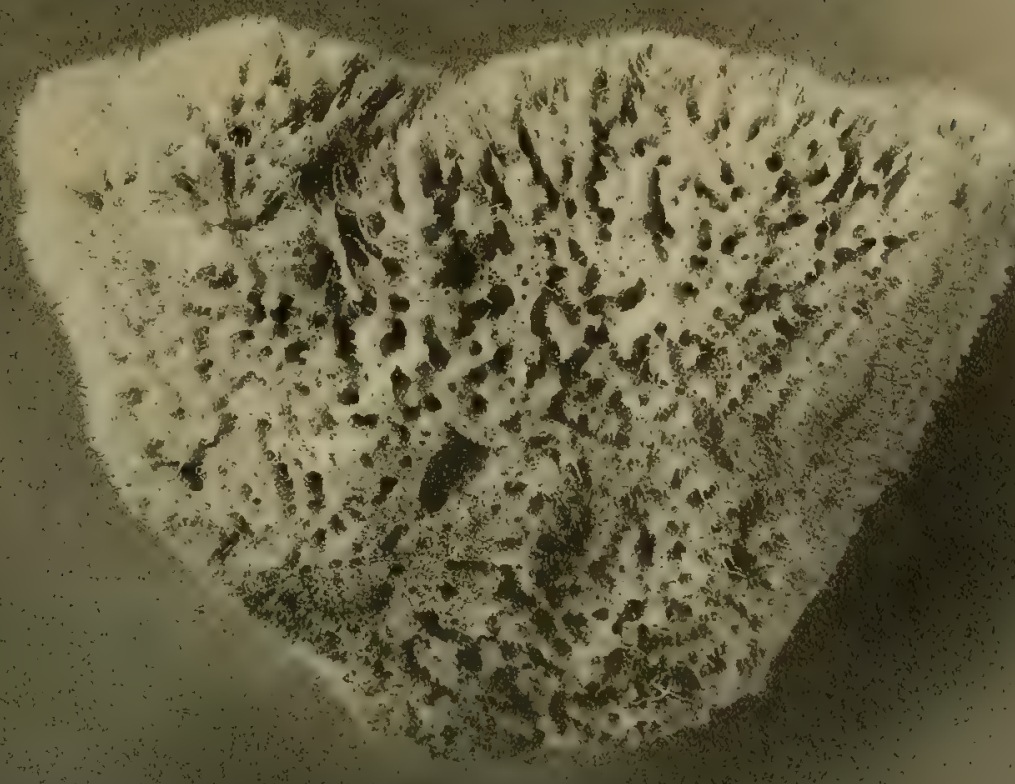

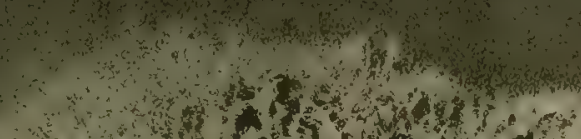

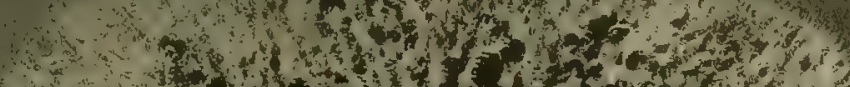

(n)

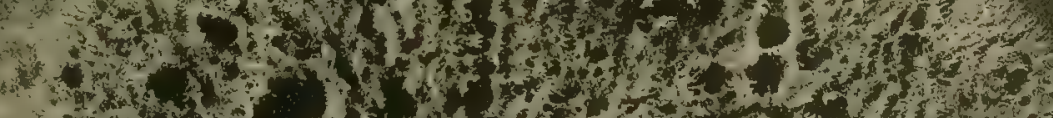

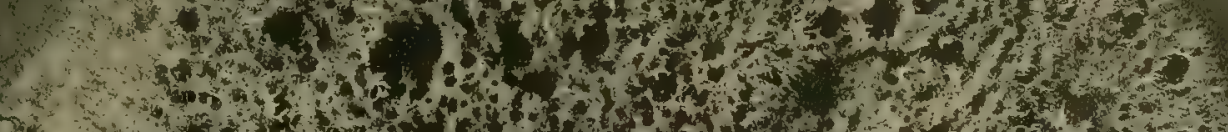

De

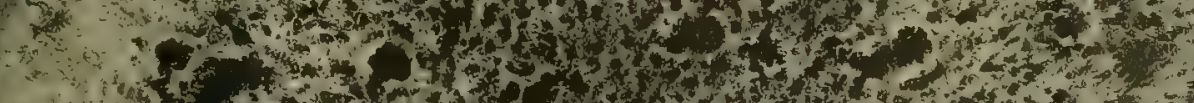

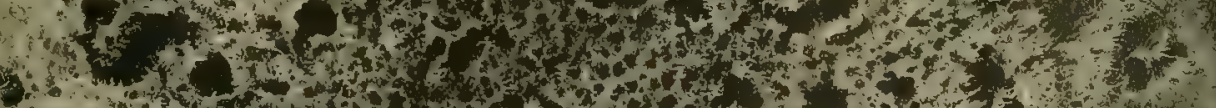

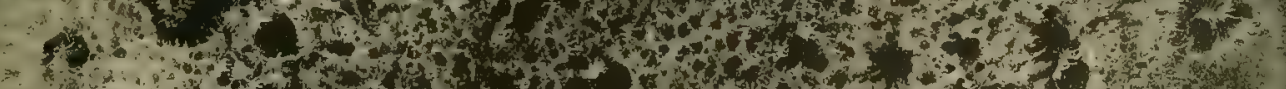

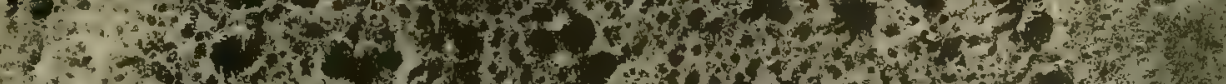

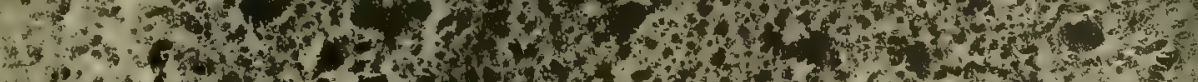
$3 \mathrm{a}$.

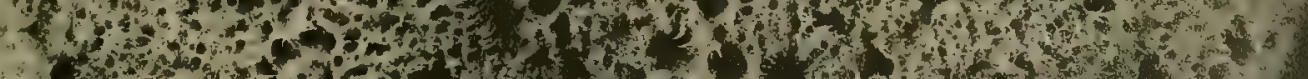
(5)

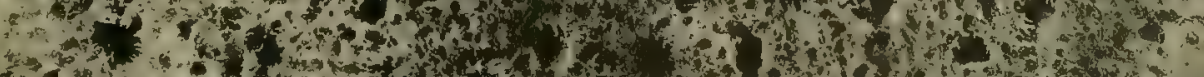

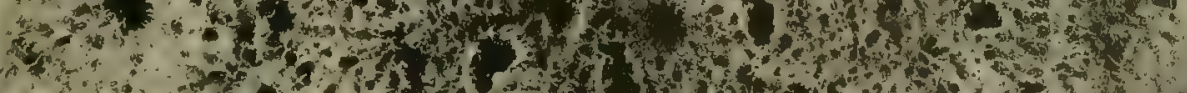
4. 3n

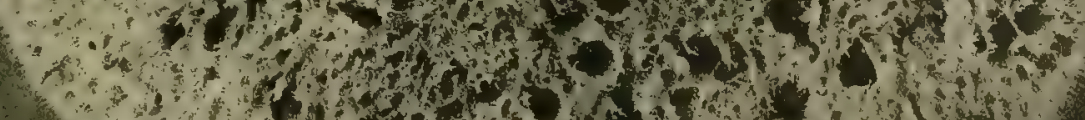

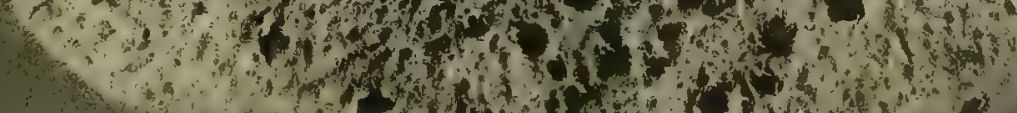

$$
\text { 14 A }
$$



Plate LXV

Honeycomb sponge, Mediterranean Sea. Natural size. 


$$
\text { Y.I 9. } 95
$$

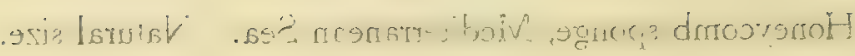




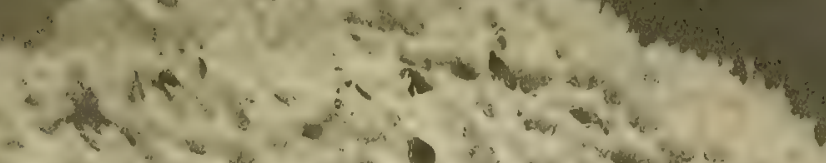

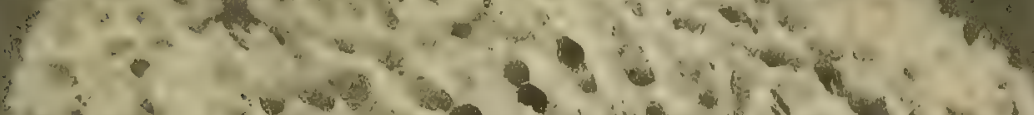

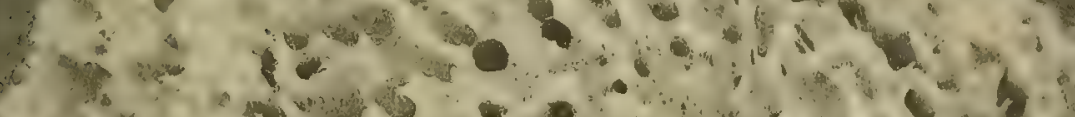

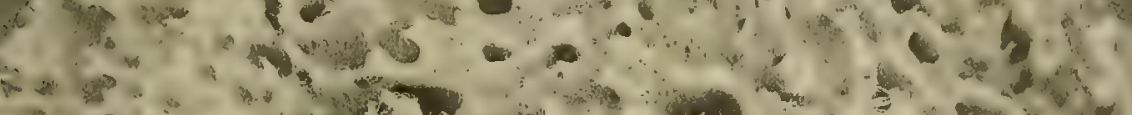

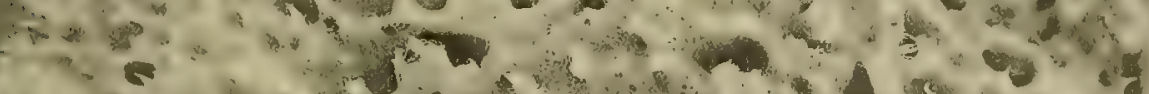

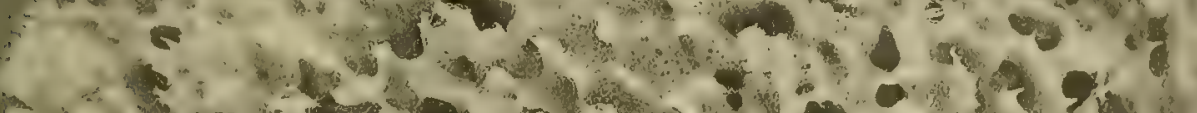

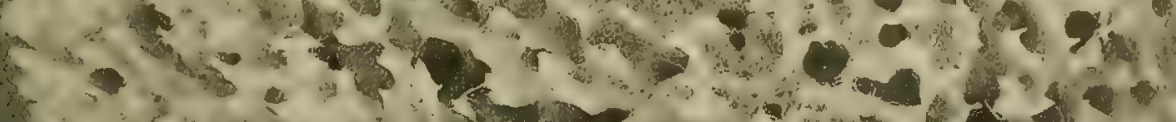

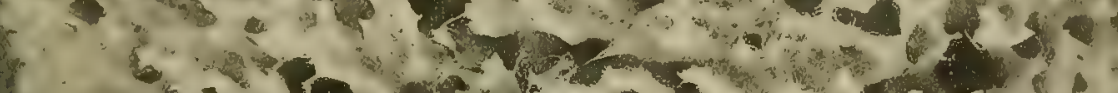

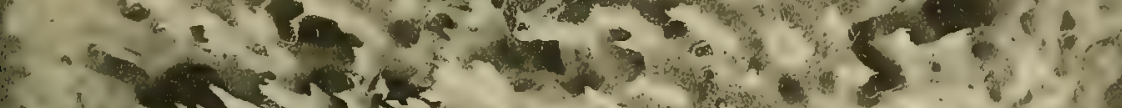

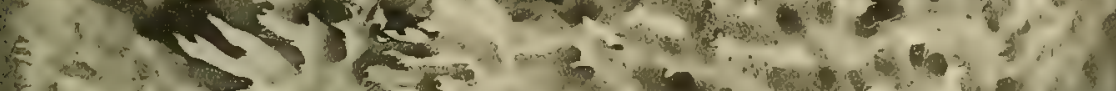

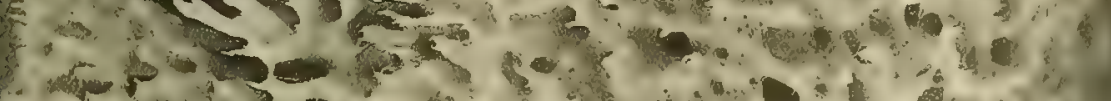

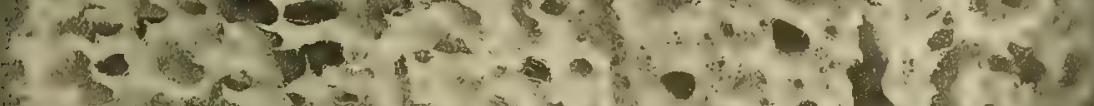

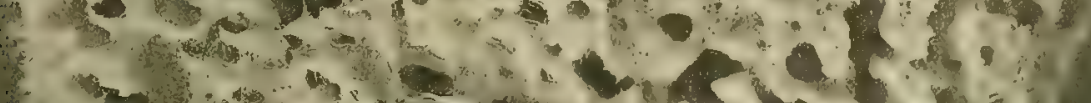

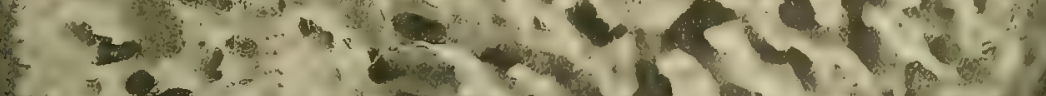

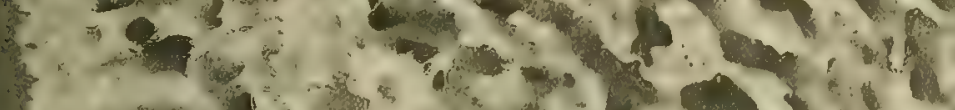

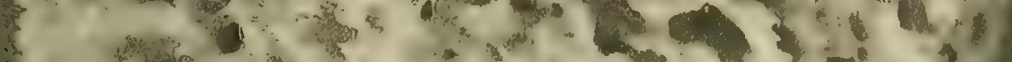

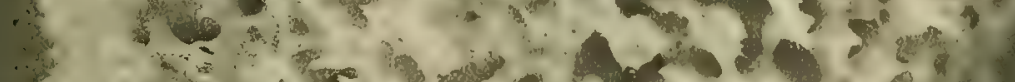

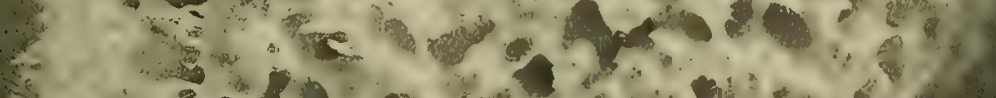

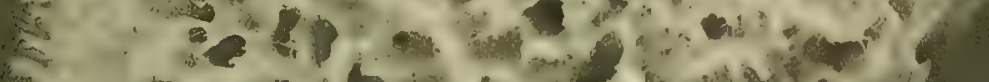

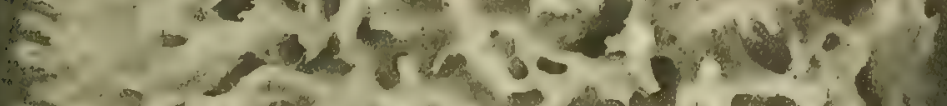

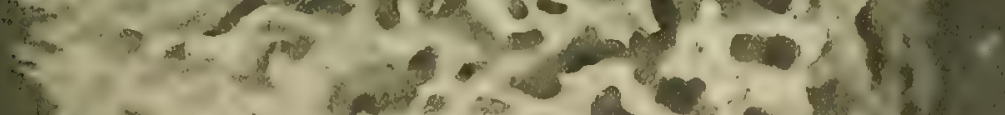

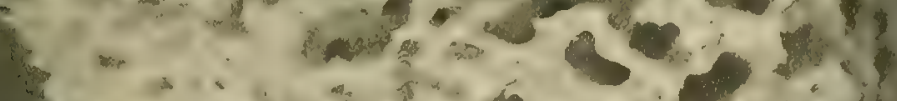

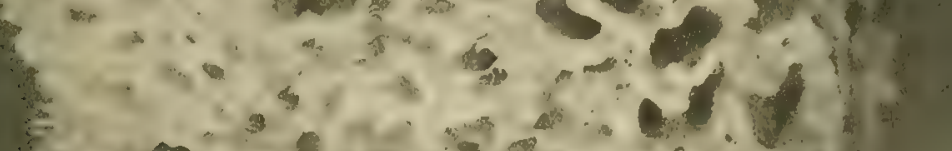

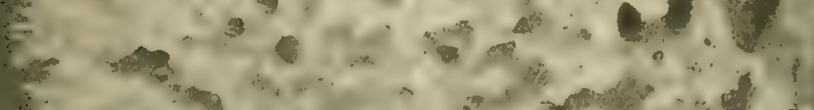

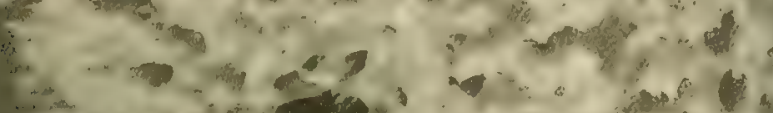

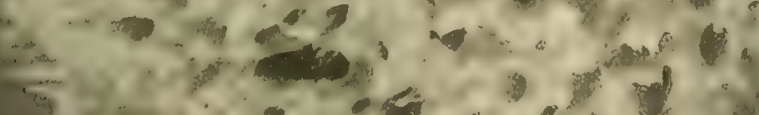

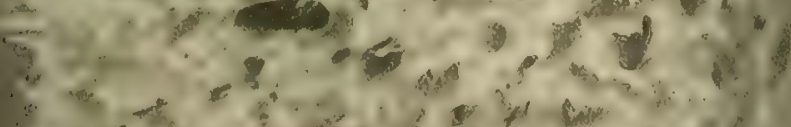

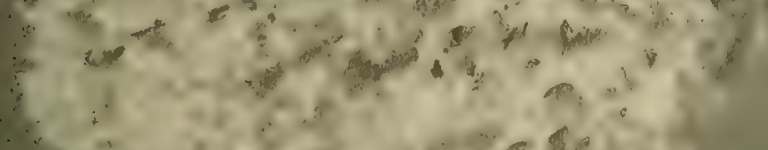

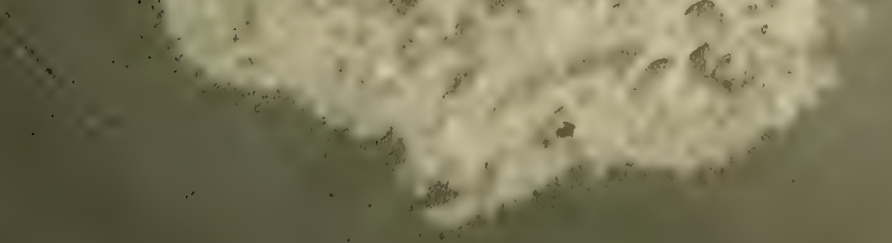





\section{Plate LXVI}

Elephant-ear sponge, Mediterranean Sea. Natural size. 
IVXI 9. 19

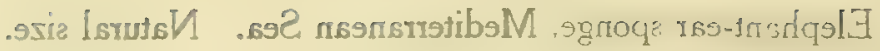




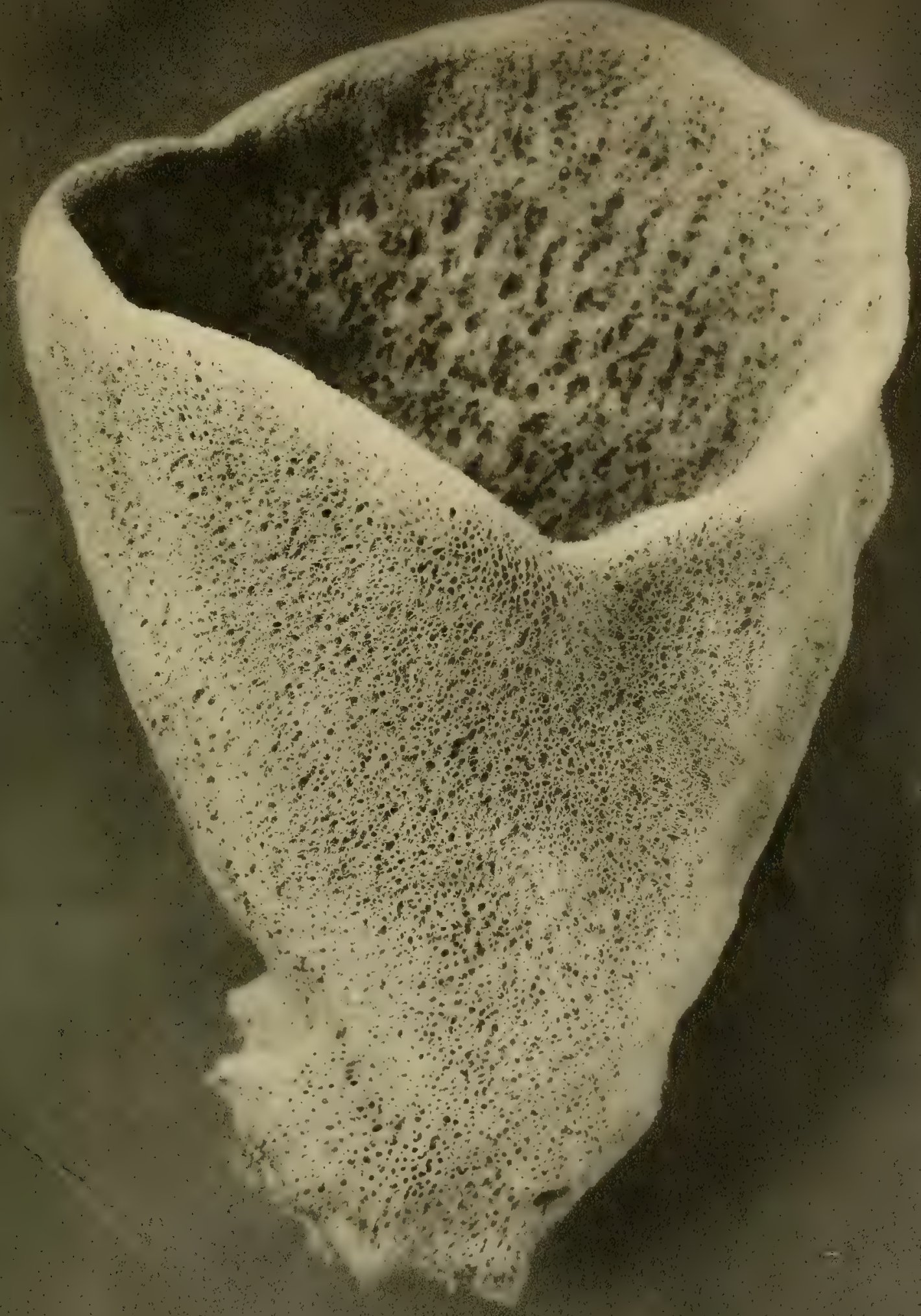


4 






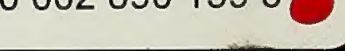

